\title{
Influência da ciclagem térmica e do método de avaliação na determinação da microinfiltração em restaurações de resina composta
}

\section{Maria Cecília Veronezi}

Tese

apresentada

à

Faculdade de Odontologia de Bauru, da Universidade de São Paulo, como parte dos requisitos para obtenção do título de Doutor em Odontologia, na área de Dentística Restauradora. 


\section{Influência da ciclagem térmica e do método de avaliação na determinação da microinfiltração em restaurações de resina composta}

\section{Maria Cecília Veronezi}

Tese

apresentada

Faculdade de Odontologia de Bauru, da Universidade de São Paulo, como parte dos requisitos para obtenção do título de Doutor em Odontologia, na área de Dentística Restauradora.

(Edição Revisada)

Orientador: Prof. Dr. Aquira Ishikiriama 


\section{Veronezi, Maria Cecília}

V599i

Influência da ciclagem e do método de avaliação na determinação da microinfiltração em restauração de resina composta. / Maria Cecília Veronezi. - Bauru, 2000. $222 \mathrm{p}$ : il. $30 \mathrm{~cm}$.

Tese. (Doutorado) - Faculdade de Odontologia de Bauru USP.

Orientador: Prof. Dr. Áquira Ishikiriama. 


\section{MARIA CECÍLIA VERONEZI}

12 de setembro de 1964

Lins, SP

Filiação

1982-1985

1988

1989

1989-1991

1991

1992

1995

1995

Associações
Nascimento

-Onofre Veronezi

-Maria Fernandes Veronezi

Curso de Graduação em Odontologia Faculdade de Odontologia de Lins-SP

Curso de Especialização em Dentística pela Faculdade de odontologia de Bauru-USP

Professora Assistente das Disciplinas de Dentística da Faculdade de Odontologia de Lins da Universidade Metodista de Piracicaba, UNIMEP-Lins.

Curso de Especialização em Periodontia e Aperfeiçoamento em Prótese pela APCDBauru-SP

Curso de Pós-graduação em Dentística, ao nível de Mestrado na Faculdade de Odontologia de Bauru-USP.

Professora Assistente da Disciplina de Dentística da Faculdade de Odontologia da Universidade do Sagrado Coração, USCBauru.

Defesa da Dissertação de Mestrado em Dentística na Faculdade de Odontologia de Bauru-USP.

Curso de Pós-graduação em Dentística, ao nível de Doutorado na Faculdade de Odontologia de Bauru-USP.

-CRO- Conselho Regional de Odontologia Secção de São Paulo.

-APCD- Associação Paulista de Cirurgiões Dentistas.

-GBPD- Grupo Brasileiro de Professores de Dentística.

-IADR- International Associations for Dental Research. 
DEDICATÓRIA 


\section{Dedico este trabalho,}

\section{A Deus,}

Você se fez presente em todos os momentos, firmes ou trêmulos. E, passo a passo, pude sentir suas mãos na minha, transmitindo-me a segurança necessária para enfrentar o meu caminho e seguir..... A Tua presença é qualquer coisa como a luz e a vida.....

Vinícius de Moraes.

\section{A minha querida Mãe,}

"Silêncio! Pois estou pensando, estou recordando...

Recordando acontecimentos, passagens já vividas, parte de minha vida... os momentos de colóquio amável, a palavra de incentivo e coragem, o carinho e a compreensão, toda a dedicação... E hoje, quando esse sonho se faz real, meus olhos com ansiedade andam de um e outro lado procurando ver alguém que também sonhou com este momento. Desesperados voam por toda parte procurando ver uma imagem, mas ela não surge, não se mostra...

Não encontram na terra este inexplicável ser...

Neste instante sentimentos tomam o meu íntimo... saudades...

Ah! Que vontade... do mesmo abraço do início, de um choro de alegria, de ouvir "Parabéns meu filho" e de dizer um muito, muito obrigado. Meus olhos rasos d'água recolhem-se... voltam-se para dentro e só aí conseguem encontrar essa imagem tão almejada.

Desaparecida... Não! Hoje, mais do que nunca, ela está presente... junto ao meu pensamento e a minha alma."

Te amo!

\section{Ao meu querido pai,}

Pelos ensinamentos e constantes exemplos de coragem, dignidade e honestidade.

Palavras não seriam suficientes para expressar o amor e admiração que sinto por você.

Obrigado! 
Ao meu orientador,

Prof. Doutor Aquira Ishikirima

Pelo exemplo de dedicação à profissão. Por ter tido a paciência de um pai e mesmo sabendo de todas minhas limitações, ainda assim, acreditou na minha vontade.

Muito obrigado por tudo! 
Agradecimentos Especiais,

\section{Aos meus irmãos Silvio, Rosângela, Onofre e Eliane,}

Deus me trouxe vocês, e meus dias se tornaram pequenos para tanta felicidade.

Com o passar do tempo surgiram as dificuldades e os problemas pareciam não ter solução. Mas novamente lá estavam vocês, e tudo se resolvia.

Um dia já cansada e desiludida quis tudo abandonar.

E quando as lágrimas rolaram, foram vocês que vieram me confortar. Agora, finalmente o dia chegou...

E ao meu lado estão vocês, como no começo de tudo, sempre a me apoiar. E neste momento eu sei que não bastaria apenas agradecer, mas mesmo assim,

Muito obrigado!

\section{As minhas cunhadas Rosângela e Maria Adelaide,}

Pessoas que sempre acreditaram e me incentivaram inúmeras vezes nesse longo tempo de convivência,

\section{Aos meus sobrinhos Silvio, Camila, Diego, Danilo, Lucas e Natália,}

Os quais agradeço por fazerem parte da minha vida. Amo muito vocês! 
Não poderia deixar de agradecer o carinho e incentivo de pessoas tão especiais, que fazem parte da minha vida:

Sonia, Sueli, Suzana, Leda,

Minha mais profunda gratidão!

Ao meu namorado Milton,

Pela grande compreensão e paciência durante a fase de elaboração final deste trabalho, e pelo carinho e cumplicidade.

“...você caiu do céu,

um anjo lindo que apareceu...."

A todos meus colegas de trabalho e amigos inseparáveis:

Carolina, Cláudia, Éster, Débora, Graziela, Laerte, Lucirene, Maria Silvia, Maria Teresa, Nádia, Renato e Silvana

sem a paciência e compreensão de vocês este dia não se realizaria,

As minhas grandes amigas Margô, Cecy e Myriam,

Pela grande amizade, apoio e incentivo, adoro vocês!

Aos meus amigos do curso de doutorado Adriana, Angela, Fátima, João, Margareth, Renata e Rogério, pelo agradável convívio e pela grande amizade.

Aos Professores Doutores Mário Honorato da Silva e Souza Júnior e Ricardo Marins de Carvalho, pela constante boa vontade em me auxiliar desde as etapas iniciais deste trabalho, 
Ao Professor Doutor Carlos Eduardo Francischone, a quem admiro muito, não somente por sua dedicação, dinamismo e perseverança, mas principalmente por sua grandeza humana,

Ao Professor Doutor José Mondelli, exemplo de dedicação profissional a arte de ensinar e sua disposição constante em colaborar com todos,

A Professora Doutora Maria Fidela de Lima Navarro, pelo seu exemplo profissional, de humildade, de grande coração e por seus valiosos ensinamentos,

A Professora Doutora Maria Teresa Atta Alves Bastos, por toda sua colaboração neste trabalho, mas principalmente pela grande demonstração de carinho e amizade,

Meu mais profundo agradecimento. 
Ao Professor Doutor Luiz Fernando Pegoraro, atual Presidente da Comissão de Pós - graduação, meu agradecimento. Pela competência com que desempenha sua função em prol dos alunos da Pós-graduação.

Aos Professores do Departamento de Dentística, Áquira Ishikiriama, Carlos Eduardo Francischone, Eduardo Batista Franco, João Lúcio Coradazzi, José Carlos Pereira, José Mondelli, Maria Fidela de Lima Navarro, Maria Teresa Atta Alves Bastos, Mário Honorato da Silva e Souza Júnior, Rafael Francisco Lia Mondelli e Ricardo Marins de Carvalho, pelo exemplo de dedicação e pela maneira singular que transmitiram o seu saber, desde o meu ingresso à especialização,

Meu muito obrigado. 
A Faculdade de Odontologia de Bauru - U. S. P., pela oportunidade que me foi concedida em pertencer ao corpo discente da Pós-graduação,

Ao Conselho Nacional de Desenvolvimento Científico e Tecnológico (CNPq), pela bolsa de estudo cedida,

A Faculdade de Odontologia de Lins - UNIMEP, por terem me apoiado nessa fase da minha carreira,

A Universidade do Sagrado Coração de Bauru, a quem agradeço por toda confiança e apoio em mim depositados,

Aos Docentes das Disciplinas de Dentística Operatória e Restauradora da Faculdade de Odontologia de Lins - UNIMEP, e aos Docentes das Disciplinas de Dentística e Clínica Integrada da Universidade do Sagrado Coração de Bauru, assim como aos alunos de ambas Instituições, pelo estímulo e apoio,

Ao Professor Doutor José Roberto Lauris, pela eficiência e precisão da análise estatística dos resultados deste trabalho,

A todos os professores da Faculdade de Odontologia de Bauru, que de alguma forma colaboraram para a minha formação no curso de Pós-graduação,

A professora Lúcia Ishiquiriama pela correção ortográfica deste trabalho,

Ao Sérgio Kioshi pela ajuda desinteressada e imprescindível na escanerização das imagens deste trabalho,

Ao Prof. Dr. Guilherme, UNESP-Araraquara, por me ceder o programa de computador utilizado para as medidas realizadas neste trabalho,

A todos os funcionários da Universidade do Sagrado Coração de Bauru e da Faculdade de Odontologia de Lins, pelo carinho e amizade,

Aos funcionários do Departamento de Dentística, Angela, Sr. Benedito, Eloísa, Elizabeth, Nelson, Rosa, Rosinha e Zuleica, sempre prontos a ajudar com competência, paciência e educação.

Aos funcionários da Pós-graduação, pela atenção a nós dispensada,

Aos funcionários da Biblioteca, sempre prontos a nos atender, em especial a Valéria pela revisão deste trabalho,

Ao funcionário da Associação de Pós-graduandos, Salvador pelo carinho e paciência,

A Edna, funcionária do Departamento de Prótese pelas correções e formatação deste trabalho,

A todos os demais que mesmo indiretamente e às vezes de uma forma oculta torceram $e$ contribuíram para a realização deste trabalho, 


\section{SUMÁRIO}

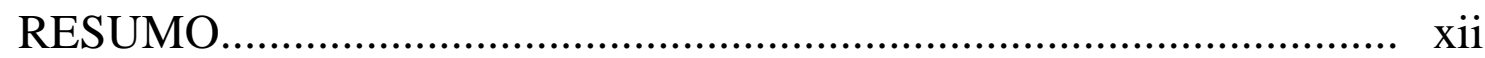

1- INTRODUÇÃO.................................................................... 1

2- REVISÃO DE LITERATURA....................................................... 8

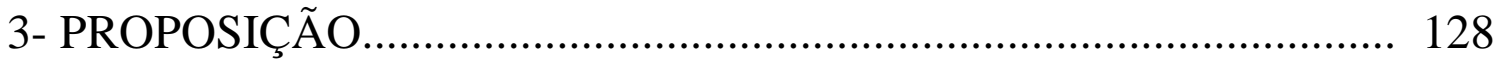

4- MATERIAL E MÉTODOS........................................................... 130

4.1- Preparo cavitário e restauração com resina composta....................... 131

4.2- Procedimentos para ciclagem térmica............................................... 134

4.3- Técnica para seccionamento dos dentes.......................................... 137

4.4- Métodos de avaliação da microinfiltração...................................... 139

4.4.1- Método qualitativo......................................................................... 139

4.4.2- Métodos quantitativos............................................................ 142

4.4.2.1- Medida linear....................................................................... 142

4.4.2.1- Medida em área............................................................... 142

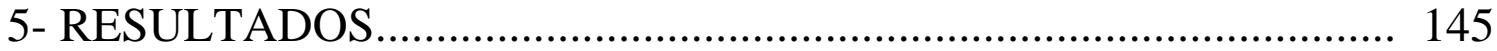

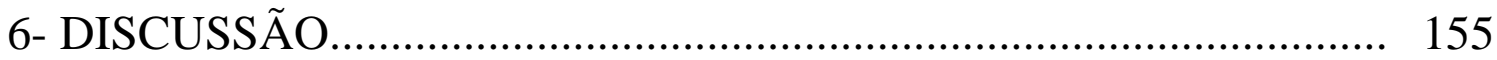

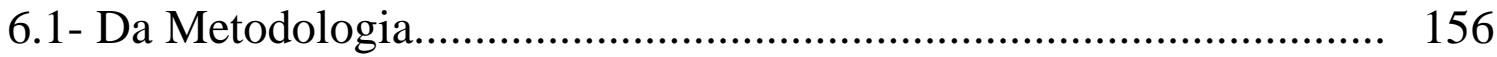

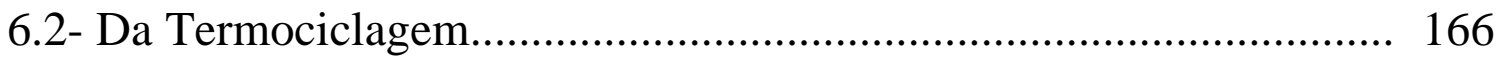

6.3- Dos métodos de avaliação............................................................. 172

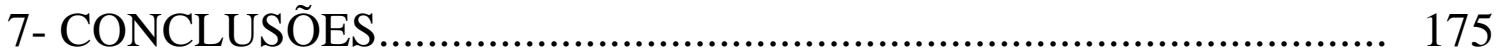

REFERÊNCIAS BIBLIOGRÁFICAS............................................ 177

ABSTRACT

ANEXOS 
RESUMO 


\section{RESUMO}

A microinfiltração na interface dente /restauração é considerada como o fator mais crítico nos materiais estéticos, como as resinas compostas, e é afetada negativamente pela sua contração de polimerização, pelo estresse mastigatório e pelo coeficiente de expansão térmica linear, que levam ao rompimento do selamento marginal. Muitas são as técnicas para testar a propriedade de selamento marginal de restaurações "in vivo" e "in vitro". Entretanto as dificuldades na realização destes estudos são diversas, e uma delas, principalmente quando a pesquisa é realizada "in vitro", é a necessidade de se reproduzirem no laboratório as condições clínicas a que são submetidos esses materiais. Uma dessas condições está relacionada às mudanças térmicas intra-orais que ocorrem clinicamente, e produzem alterações volumétricas, permitindo a microinfiltração. O processo "in vitro" ou laboratorial que reproduz estas mudanças é denominada ciclagem térmica, e é definida como o processo que submete a restauração e o dente à temperaturas extremas compatíveis com as que ocorrem na cavidade oral. $\mathrm{O}$ objetivo deste trabalho foi verificar a influência do número de ciclos no processo de termociclagem para o estudo da microinfiltração marginal de restaurações de resina composta, assim como comparar os métodos de avaliação desta microinfiltração: quantitativos (medida linear e da área) e qualitativo ( escores) dos espécimes. Para isto, cavidades circulares foram confeccionadas em 76 pré-molares, localizadas totalmente em cemento e/ou dentina e restauradas com o sistema Scotchbond Multi Purpose Plus / Z-100. Terminadas as restaurações, os dentes foram armazenados imersos em água destilada por 24 horas em uma estufa a $37^{\circ} \mathrm{C}$. A seguir os dentes foram polidos e divididos em 4 grupos, que se diferenciaram apenas no número de ciclos a que foram submetidos:

- Grupo 1- não foi submetido a ciclagem térmica (controle)

- Grupo 2- submetido a 100 ciclos

- Grupo 3- submetido a 200 ciclos

- Grupo 4- submetido a 1000 ciclos. 
As temperaturas utilizadas foram de $5^{\circ} \mathrm{C}$ e $55^{\circ} \mathrm{C}$, e os espécimes permaneceram imersos 15 segundos em cada banho. Para se evitar a penetração do corante em áreas indesejadas, todos os dentes tiveram seus forames apicais ampliados e em seu interior foi condensado amálgama e toda a superfície do dente foi coberta com 2 camadas de esmalte para unha, exceto $1 \mathrm{~mm}$ ao redor das restaurações.

Terminado o processo de termociclagem, os dentes, inclusive os do grupo controle (sem ciclagem), foram armazenados e submersos em fucsina a $0,5 \%$, a $37^{\circ} \mathrm{C}$ por 24 horas. Os espécimes foram totalmente incluídos em cilindros de resina poliestirênica, adaptados à máquina de corte, e para cada espécime cerca de 4 secções foram obtidas. Estes cortes foram avaliados pelos métodos qualitativo (escore) e quantitativos (linear e área), e a seguir os resultados avaliados estatisticamente pelos testes de Kruskall-Wallis e de Correlação de Spearman. Com base nessa análise, pode-se concluir que:

- a termociclagem, nas condições em que foi empregada neste trabalho, não demonstrou influência estatisticamente significante na microinfiltração em restaurações de resina composta, quando comparados os grupos não ciclado e os termociclados (100, 200 ou 1000 ciclos);

- as metodologias de leitura qualitativa (escores) e quantitativas (linear e área), para medir a infiltração do corante se equivaleram, tanto nas avaliações dos valores médios como dos máximos de penetração do corante. 


\section{1 - INTRODUÇÃO}




\section{1- Introdução}

A integridade marginal das restaurações é um importante parâmetro para se avaliar a longevidade de um material restaurador ${ }^{190}$, uma vez que a formação de um espaço entre o dente e o material está associado a cáries recorrentes e injúrias pulpares. Este espaço marginal, permite a microinfiltração e é definido como a passagem de bactérias, fluidos, moléculas ou íons entre a parede cavitária e o material restaurador ${ }^{104}$. A microinfiltração na interface dente/restauração é considerada como o fator que exerce maior influência sobre a longevidade das restaurações dentárias ${ }^{129}$. BLACK ${ }^{15}$ enfatizava que os materiais restauradores poderiam ser perfeitamente adaptados às paredes cavitárias e livres de alterações dimensionais quando introduzidos na cavidade oral. Sabemos, entretanto, que isto não é uma realidade e por essa razão é objetivo da Odontologia a procura de um material restaurador que se una quimicamente à estrutura dentária para formar um perfeito selamento, capaz de resistir às agressões sofridas na cavidade oral, tais como a presença de umidade e mudanças freqüentes de temperatura ${ }^{6,83}$.

Os principais efeitos da microinfiltração são manchamento das margens da restauração, cárie secundária na interface dente/restauração e o desenvolvimento de patologias pulpares ${ }^{44,82,207}$.

Muitos estudos ${ }^{50,165}$ têm investigado os efeitos dos materiais e as técnicas de utilização no grau de microinfiltração. Consideráveis esforços têm sido empregados na tentativa de se reduzir o máximo possível a microinfiltração. Estes esforços incluem o uso de ácidos para condicionamento da superfície dentária, biselamento do ângulo cavo-superficial, sistemas adesivos para esmalte e dentina, vernizes cavitários e vários tipos de materiais adesivos, assim como alguns materiais com reduzido coeficiente de expansão térmica linear.

Enquanto a microinfiltração é mais crítica nos materiais adesivos, como as resinas compostas, alguns pesquisadores demonstraram que quanto mais antiga a restauração de amálgama, menor o grau de microinfiltração ao seu redor ${ }^{92,153}$. PICKARD; GAYFORD ${ }^{154}$ atribuíram à formação de produtos 
de corrosão na interface dente/restauração de amálgama, o sucesso clínico deste material restaurador. Outros pesquisadores ${ }^{6,42,58,64,83,86,153}$ atribuíram à aplicação de verniz cavitário às paredes da cavidade a redução de microinfiltração inicial ao redor de restaurações de amálgama ${ }^{153}$.

Entretanto, com os materiais adesivos não ocorre o mesmo fenômeno. O material restaurador ideal seria o que se unisse fortemente aos tecidos dentários, que possuísse propriedades físicas semelhantes à estrutura dentária, que fosse de fácil utilização e possuísse uma estética favorável ${ }^{13}$. A resina composta está se desenvolvendo e caminhando para se unir química/ou micromecanicamente à estrutura dentária ${ }^{31,62}$. A técnica do condicionamento ácido foi o primeiro e significante passo para promover uma forte união entre a resina composta e o esmalte ${ }^{27,28}$. Esta técnica promoveu uma grande união micromecanica entre as duas estruturas e, o selamento marginal em cavidades que possuem uma quantidade razoável de esmalte de boa qualidade em todas as margens que a envolvem, é considerado bastante efetivo $28,35,161,166,182$. No entanto, cavidades que possuem suas margens localizadas além da junção amelo-dentinária e são restauradas com resina composta, não apresentam um selamento satisfatório 1,17,31,35,38,39,43,48,49,50,51,57,60,62,66,68,69,75,82,87,97,106,109,125,132,138, $142,147,148,155,163,164,165,171,174178,182,184,185,187,193,194,201$. Esta menor união à dentina se deve principalmente às suas características morfológicas e estruturais que transformam o processo adesivo em um fenômeno muito mais complexo

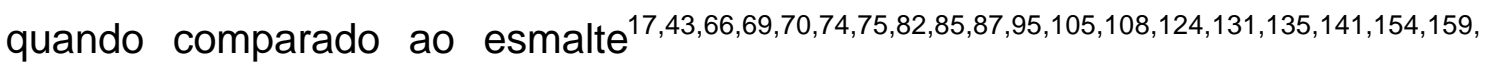
$166,160,170,177,181,184,185,187$. Uma das principais características da dentina é ser um tecido muito complexo, dinâmico e permeável por apresentar túbulos dentinários que se estendem desde a câmara pulpar até a junção amelodentinária e abrigam em seu interior os prolongamentos citoplasmáticos dos

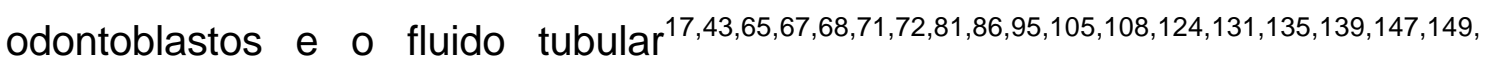
154,159, 160,166,170,177,181,183,185,192,193, o que torna a adesão mais difícil pelo fato de se apresentar constantemente úmida, biologicamente mais sensível, com baixa energia livre de superfície e por possuir uma grande quantidade de componentes orgânicos e se apresentar ainda coberta por uma camada de detritos ou "smear layer", que é produzida durante a instrumentação da cavidade ${ }^{53,65,79,116,135,142,146,163}$. Entretanto, o sucesso da adesão obtido pelo 
condicionamento ácido do esmalte ${ }^{27,28}$ estimulou pesquisadores a estudar 0 preparo da superfície da dentina para se obter uma adesão efetiva a esta estrutura $^{13,14,24,62,71,107}$.

Os primeiros sistemas adesivos dentinários foram desenvolvidos para se unirem quimicamente a alguns componentes da dentina e a "smear layer". Entretanto, ficou evidente depois de um certo tempo, que esta adesão por meio da "smear layer" era fraca e apresentava falha coesiva ${ }^{13}$. Quando comparada à adesão da resina composta ao esmalte, a união à dentina exibiu valores de união bem mais baixos ${ }^{28,31}$ e ficou claro que a remoção da "smear layer" seria necessária para se conseguir uma união eficiente com a dentina. Recentemente, as pesquisas estão sendo concentradas na remoção de "smear layer" e da superfície mineral da dentina, mas sem causar danos ou irritações à polpa dental. O colágeno remanescente dessa desmineralização parcial, é então impregnado por um monômero de capacidade hidrofílica, que quando polimerizado formará a chamada camada híbrida ou camada resinoreforçada ${ }^{14,54,62,71,107,138,149}$.

A microinfiltração também é afetada negativamente pela contração de polimerização da resina composta ${ }^{1,2,3,4,18,26,34,35,42,59,66,88,89,105}$, 145,150,194, que produz uma abertura das margens da restauração ou um microespaço entre o material restaurador e a parede cavitária e que não é compensada totalmente pela posterior expansão higroscópica, ou seja, pela sorpção de água pelo material restaurador. ASMUSSEN e JORGENSEN ${ }^{4}$, relataram que o microespaço provocado pela contração de polimerização não foi fechado totalmente mesmo depois de os espécimes permanecerem estocados por 32 dias em água. Outro fator negativo com relação à microinfiltração é a deformação produzida pelo estresse mastigatório, assim como as mudanças dimensionais, expansão e contração da estrutura dentária e do material restaurador provocadas pelas mudanças térmicas ocorridas no ambiente oral (coeficiente de expansão térmico linear), que levam a um rompimento no selamento marginal e consequentemente à microinfiltração ${ }^{141,165}$.

Muitas são as técnicas utilizadas para testar a propriedade de selamento cavitário de restaurações "in vivo" e "in vitro". Entretanto, as 
dificuldades na realização destes estudos são diversas, e uma delas, principalmente quando a pesquisa é realizada "in vitro', é a necessidade de reproduzir no laboratório as condições clínicas a que são submetidos esses materiais. Uma dessas condições está relacionada às mudanças térmicas intraorais que ocorrem clinicamente e que como já citado anteriormente, produzem alterações volumétricas, permitindo a infiltração de bactérias ou outros elementos na interface dente/restauração. Observa-se na literatura específica que a grande maioria procura realizar ciclagens térmicas nas quais os espécimes passam alternadamente em soluções contendo corantes, saliva ou água, a diferentes temperaturas na tentativa de reproduzir essas variações que ocorrem clinicamente $e^{1,78,87,104,170,202}$.

A termociclagem, é o processo "in vitro" que submete a restauração e os dentes a temperaturas extremas compatíveis com as que ocorrem na cavidade oral. Isto simula a ingestão de alimentos quentes e frios na cavidade oral e demonstra a relação do coeficiente de expansão térmica linear entre o dente e o material restaurador ${ }^{49,76,170,202}$. Essas diferenças extremas do coeficiente de expansão térmica linear entre o dente e o material restaurador causam a "percolação" e, consequentemente, a microinfiltração ${ }^{46,141,146}$. NELSEN; WOLCOTT; PAFFENBARGER ${ }^{141}$, foram provavelmente, os primeiros a demonstrar a percolação marginal devido a mudanças térmicas.

As temperaturas usadas nos procedimentos de termociclagem variam, na grande maioria das pesquisas, de $4^{\circ} \mathrm{C}$ em conjunto com $60^{\circ} \mathrm{C}$ $105,133,178$, ou $15^{\circ} \mathrm{C}$ com $45^{\circ} \mathrm{C}^{78,88,152}$, enquanto outros utilizam ciclos com $5^{\circ} \mathrm{C}$ e $55^{\circ} \mathrm{C}^{87}$

O tempo usado para imersão nas soluções quente e fria tem variado entre $10 s^{166}, 15 s^{116,164,166,202}, 30 s^{26,52}, 60 s^{12,68,72,97,131,166,201}$, e $120 s^{131}$. Entretanto, CAUSTON et $\mathrm{al}^{36}$ demonstraram que usando um menor tempo de imersão relata mais fielmente o que acontece clinicamente.

O número de ciclos empregados variam de 1 a 2500 e até 50.000 vezes $^{112}$. PETERSON; PHILLIPS; SWARTZ152 relataram que a microinfiltração aumenta com o aumento do número de ciclos quando se está testando resina composta $^{112}$. MANDRAS; RETIEF; RUSSELL ${ }^{117}$ demonstraram não haver 
diferenças na microinfiltração de resinas compostas termocicladas com 250 e 1000 ciclos. Entretanto, alguns autores ${ }^{79,105,202}$ sugeriram que os testes de termociclagem de restaurações de resina composta podem não ter significância clínica.

Os estudos "in vitro" para detectar microinfiltração incluem o uso de corantes, traçadores químicos, isótopos radioativos, pressão a ar, bactérias, análise de ativação de neutrons, microscopia eletrônica de varredura, técnicas de cáries artificiais, e condutibilidade elétrica ${ }^{1,8,84,93,104,153 .}$

Para avaliar os testes "in vitro" de infiltração marginal uma grande variedade de métodos tem sido descrito ${ }^{191}$. Os testes que utilizam a penetração de corantes são mais comuns principalmente por ser um método mais simples e rápido. Esta avaliação é geralmente realizada pela medida em profundidade de uma ou várias secções dos dentes restaurados e embebidos em resina epóxica. A natureza do critério de avaliação (quantitativo, ordinal, qualitativo ) determina o poder do teste estatístico realizado ${ }^{56}$.

Um tipo de critério avalia a penetração do corante em apenas uma secção do dente restaurado ${ }^{59,179}$. Esse critério de avaliação não nos permite levar em conta a variação de penetração do corante de um lado ao outro da interface dente/restauração ${ }^{77}$. Levando em conta esta variação, várias secções de cada dente devem ser examinadas e consequentemente, várias medidas devem ser feitas. Nesses casos, vários métodos são propostos para aproveitar o máximo possível os dados obtidos de cada secção. Cada medida pode ser considerada como um critério estatístico, ou um critério reunindo todos os dados de cada dente calculado ${ }^{188}$. As análises estatísticas dos dados são freqüentemente representadas pelos valores médios, ou seja, média, mediana, ou moda dos valores ${ }^{56}$. Podendo também apenas utilizar a profundidade máxima de penetração do corante em cada dente ${ }^{184}$.

Devido à grande diversidade de métodos de avaliação "in vitro" da microinfiltração marginal existentes na literatura, algumas dúvidas surgem entre os profissionais e pesquisadores. Principalmente com relação à quantidade de vezes que um espécime passaria por cada solução nas várias temperaturas da termociclagem; a forma em que estes espécimes seriam avaliados, qualitativa ou quantitativamente, com relação a penetração do corante na interface 
dente/restauração e como estes dados seriam distribuídos para serem avaliados estatisticamente (média, mediana, valor mais alto de penetração, moda).

A partir destas observações, planejou-se o presente trabalho de pesquisa com o objetivo de comparar algumas etapas do teste de infiltração marginal das restaurações de resina composta, como a inflência do número de ciclos térmicos a que são submetidos os espécimes e o método de avaliação empregado para avaliar a microinfiltração. 
2 - REVISÃO DE LITERATURA 


\section{2- Revisão da Literatura}

Em 1952, NELSEN; WOLCOTT; PAFFENBARGER ${ }^{141}$, avaliaram o efeito das variações de temperatura na estabilidade dimensional de alguns materiais restauradores (guta-percha, cimento de óxido de zinco e eugenol, amálgama, ouro e resina acrílica). Verificaram que as mudanças térmicas produziram um intercâmbio de fluídos entre o dente e os materiais testados. Esta infiltração ocorria devido as diferenças entre os coeficientes de expansão térmica do dente e dos materiais restauradores e pela expansão térmica dos fluídos já existentes nas fendas marginais produzidas.

Em 1952, FIASCONARO; SHERMAN ${ }^{70}$, desenvolveram um método para medir e relatar objetivamente as propriedades de selamento de materiais dentários. A técnica descrita consiste na confecção de preparos classe $\mathrm{V}$ padronizados em molares extraídos e em seguida restaurados. A raiz dos dentes é cortada, a câmara pulpar limpa e a porção aberta da coroa é individualmente conectada a um conjunto de tubulação de bronze e borracha. $\mathrm{E}$ por último é unido a um compressor de ar que libera ar para o interior da coroa que é submersa em água. A pressão do ar é aumentada até que a primeira bolha apareça no margem da restauração. Segundo os autores, esta técnica permite testar a restauração em várias condições físicas e em diferentes intervalos de tempo. Testaram alguns materiais e os resultados foram expressos em libras por polegada quadrada: ouro em folha $=50+$, Kyptex $=$ $50+$; cimento de fosfato de zinco $=50+;$ silicato $=38+$; inlay de ouro selado com cimento $=45$; inlay de ouro selado com resina acrílica $=20$; inlay acrílica selado com cimento $=29$. Concluíram que as restaurações testadas apresentaram valores considerados baixos. Mas consideraram que este método pode ser usado para avaliar técnicas restauradoras assim como materiais.

Em 1953, PAFFENBARGER; NELSEN; SWEENEY ${ }^{146}$, avaliaram a utilização das resinas sintéticas, utilizadas na época, comparando as restaurações indiretas e diretas com este material. Citaram que a aplicação 
desta resina depende de uma variedade de propriedades com utilização específicas em cada especialidade; dependem dos seguintes fatores: 1) quantidade de alteração dimensional e deformação durante a polimerização e em contato com o ambiente bucal; 2) propriedades estéticas; 3) efeitos químicos na boca; 4) propriedades mecânicas. Fizeram também uma revisão dos muitos relatos publicados sobre as propriedades físicas e químicas das resinas restauradoras diretas e indiretas e chegaram a algumas conclusões importantes: 1) a contração volumétrica irrestrita destas resinas é de aproximadamente $7 \%$; esta contração não pode ser suprida, mas nas restaurações indiretas pode-se direcioná-la, tornando-a menos prejudicial. Utilizando uma técnica apropriada, grande parte da contração pode ser levada a concentrar-se próximo ao assoalho da cavidade; 2) a expansão destas resinas é de 0,9 a 1,5\% por volume, quando imersas em água; 3) a deformação da resina é aparentemente causada pela liberação de tensão, uma vez que os espécimes temperados não se deformam após a imersão em água; 4) a grande diferença entre as resinas e os tecidos dentais, ou seja, o coeficiente de expansão térmica provoca a abertura e depois, o fechamento de um espaço entre o dente e a restauração nas variações de temperatura encontradas na boca; este espaço freqüentemente permite uma troca de fluídos na margem de restauração. Terminaram sugerindo que, na avaliação de qualquer material restaurador, alguns critérios fossem adicionados aos costumeiros: a capacidade do material restaurador de estimular a produção de dentina secundária e a capacidade do material restaurador de prevenir a recorrência de cárie.

Em 1953, COY $^{46}$, num estudo sobre resinas diretas relataram que as resinas autopolimerizáveis foram introduzidas na odontologia aproximadamente dois anos após a publicação do relato Blumenthal em 1947. Esse relato era parte de um estudo de desenvolvimentos científicos alemães por uma comissão que operava sob a direção do governo militar da Alemanha após a segunda guerra mundial. Esta comissão relatou a descoberta dos pesquisadores alemães de um método para endurecer ou polimerizar as resinas acrílicas em temperatura ambiente. Os autores citam as qualidades 
primárias das resinas diretas estabelecidas pelo National Bureau of Standards: 1) contração volumétrica durante a polimerização de 5,5 a $8 \%$; 2) expansão volumétrica de 1 a 15\%; 3) alteração dimensional térmica por volta de 8 vezes, mais que a estrutura dental; 4) não adesão à estrutura dental; 5) insolubilidade nos líquidos bucais; 6) instabilidade de cor. Afirmaram que a avaliação final de qualquer material restaurador deve ser estabelecida por experiência, o que determina que os estudos devem ser longos para que os dados sejam examinados em fatos e não em opiniões. Algumas observações clínicas realizadas pelos autores indicaram que a mudança de temperatura de substâncias quentes para frias na cavidade oral, se atingisse a restauração não atingiria a temperatura suficiente para quebrar o selamento cavitário. Os autores afirmaram que o tamanho da restauração afeta grandemente 0 tamanho da abertura marginal e quanto maior o volume do material, maior será o volume da abertura. Concluíram, portanto, que as resinas restauradoras diretas não preenchem todos os requisitos primários (já citado) e secundários (aparência e cor, não condutibilidade térmica, e conveniência de manipulação), e também nem um outro até então alcançava. O importante, afirmaram, é que a resina tem seu lugar na odontologia, e que é preciso aperfeiçoá-la para que não apresentem infiltração e recorrência de cáries.

ROSE; GREEN; CORNELL ${ }^{169}$, em 1955, realizaram um estudo sobre resinas para restaurações diretas avaliando o coeficiente de expansão térmica e absorção de água do polimetilmetacrilato. Segundo os autores, as resinas expandem aproximadamente sete vezes mais que a estrutura natural do dente, e a contração de polimerização é de um total de 6 a $8 \%$ por volume, e devido a precária adesão da resina restauradora às paredes da cavidade dentária a contração de polimerização pode criar um espaço vazio na interface dente/restauração. Quando a temperatura se eleva, esse espaço diminui. Admitiram a essas oscilações de temperatura o fenômeno da percolação e a penetração de detritos e bactérias na interface dente/restauração. $O$ procedimento utilizado neste trabalho para determinar o coeficiente de expansão térmica foi uma ligeira modificação do método AST.M.. As cargas usadas consistiram de alumínio, sílica, fosfato de bório, carbonato de cálcio e 
óxido de zinco. Os resultados indicaram que as cargas inorgânicas podem ser usadas com vantagens para reduzir o coeficiente de expansão térmica das resinas. As variadas cargas utilizadas não se diferem uma das outras em baixas concentrações no que diz respeito ao coeficiente de expansão térmica, entretanto em altas concentrações, algumas diferenças são notadas. Os autores puderam concluir que: 1) o coeficiente de expansão térmica do polimetilmetacrilato diminuiu com a adição de várias cargas inorgânicas; 2) quanto maior a quantidade de carga adicionada ao polimetilmetacrilato maior foi a redução no coeficiente de expansão térmica; 3) aumento de peso devido à absorção de água do polimetilmetacrilato foi reduzido pela adição de várias cargas inorgânicas; porcentagens mais altas de carga adicionadas produzem maiores reduções em ganho de peso; 4) a alteração do $\mathrm{pH}$ não teve efeito aparente na absorção de água do polimetilmetacrilato; 5) a adição de outro material ao polimetilmetacrilato não alterou significamente as propriedades de absorção de água da resina.

A penetração de microorganismos entre o dente e as restaurações diretas de resina foi o objetivo do estudo de SELTZER ${ }^{177}$, em 1955. De acordo com o autor, o uso das resinas acrílicas em restaurações levou a várias investigações concernentes à permeabilidade nas margens entre a estrutura dental e a restauração. Após a revisão de alguns estudos anteriores foi apresentada uma série de experimentos nos quais a penetração foi testada por meio de microorganismos corados. Utilizou cavidades de Classe $\mathrm{V}$ preparadas nas superfícies vestibulares de dentes recém extraídos, livres de cárie ou cáries em superfícies que não envolviam áreas de teste. As cavidades foram restauradas com resina acrílica ou amálgama. Depois eram submersos em solução salina e colocados na incubadora a $73^{\circ} \mathrm{C}$ por 24 horas e então polidas. Os dentes foram divididos em dois grupos de acordo com o microorganismo empregado, B. globigü (cor laranja) e S. marcescens (cor vermelha) eram submersos num caldo de cultura com os microorganismos em uma encubadora por 7 a 60 dias. Uma ou duas vezes por dia, eram retirados da encubadora e imersos em água gelada ou quente, ou ambas. No final do período de teste, lascas de dentina sob a restauração eram cultivadas para determinar se os microorganismos 
haviam penetrado. Os microorganismos não penetraram nas margens das restaurações em que os dentes não receberam mudanças térmicas. Nas restaurações que sofreram alterações térmicas, houve penetração de microorganismos, especialmente se a exposição dos microorganismos de teste tinham sido por períodos de 30 dias ou mais. As restaurações de amálgama que receberam tratamento térmico, dificilmente permitiram a penetração de microorganismos (uma dentre 20), mas muitas das restaurações de acrílico permitiram a penetração (17 das 80). Houve uma penetração maior de B. globigü nas restaurações de resina restauradas pela técnica de pinceladas; com respeito aos S.marcescens não houve diferenças entre as técnicas de restauração. Esta diferença pode ser explicada pelos tamanhos dos dois microorganismos.

BUONOCORE ${ }^{27}$, em 1955, relatou que uma das maiores desvantagens dos acrílicos e de outros materiais restauradores era a falta de adesão à estrutura dental. Um material com tais características tornaria desnecessária a retenção e resistência no preparo cavitário, e o selamento de cicatrículas, fissuras e lesões cariosas incipientes tornaria-se efetivo. $O$ autor cita algumas tentativas de se obter uma união entre os materiais restauradores e a estrutura dental: o desenvolvimento de novos materiais com propriedades adesivas; modificação dos materiais existentes na época tornando-os adesivos; uso de revestimentos como materiais de interface adesiva entre a restauração e o dente; alteração da superfície dental pelo tratamento químico para produzir uma nova superfície à qual os materiais existentes pudessem aderir. Neste estudo Buonocore testou duas substâncias, solução ácida oxálica a 10\% e solução de ácido fosfórico a $85 \%$, para tratar as superfícies do esmalte na tentativa de aumentar a retenção do material restaurador ao dente. Com o uso do ácido oxálico esperou produzir uma superfície quimicamente diferente, achava que o ácido-molibdato removeria camadas superficiais do esmalte. Quanto ao uso do ácido fosfórico o pensamento foi de provocar uma simples descalcificação resultando em remoção da estrutura superficial para produzir uma superfície mais receptiva à adesão. Aumentando a capacidade de molhamento da superfície, permitindo um contato mais íntimo entre o material e 
o esmalte, favorecendo a adesão. Observando os resultados, o autor sugeriu o uso do tratamento com ácido fosfórico que pareceu fornecer melhores resultados e é mais simples de usar

É fato conhecido que em 1956 os materiais restauradores não tinham adesão à estrutura dentária sob condições orais. Por este motivo BUONOCORE; WILEMAN; BRUDEVOLD ${ }^{28}$, realizaram uma pesquisa sobre a composição de uma resina capaz de se unir à superfície da dentina humana. Procuraram imitar as condições do meio ambiente bucal deixando os dentes imersos em água $e$ depois secos com material absorvente $e$ subseqüentemente com ar comprimido por vários segundos, estes espécimes foram chamados de espécimes molhados. A adesão foi avaliada observandose a resistência oferecida pelo material à remoção por pressão aplicada com um instrumento agudo. Os resultados desses testes indicaram que com uma exceção, as resinas acrílicas obtiveram pouca ou nenhuma adesão às superfícies da dentina molhada. A adesão ao esmalte foi excelente para todas as resinas testadas, entretanto quando os espécimes ficaram imersos por 24 horas em água, esta adesão era destruída. Consideraram melhor a adesão ao esmalte que a dentina por se conseguir uma melhor secagem do primeiro. Quando os autores compararam a adesão em superfícies tratadas com ácido e não tratadas, concluíram que o ácido não aumentou a adesão das resinas acrílicas, entretanto nos materiais considerados adesivos, nas superfícies condicionadas a adesão aumentou em aproximadamente duas vezes. E a perda de adesão com o tempo pareceu ser mais gradual do que as não tratadas com ácido. Ao avaliar os resultados enfatizaram que são achados laboratoriais obtidos em condições que podem se aplicar na boca. Concluíram que:- demonstraram um material de resina acrílica adesiva que realiza uma forte união às superfícies dentinárias "molhadas" de dentes extraídos; as uniões mostraram boa resistência à imersão em água. Para as superfícies não tratadas com ácido as resistências iniciais de $28 \mathrm{Kg} / \mathrm{cm}^{2}$ foram reduzidas para $15 \mathrm{Kg} / \mathrm{cm}^{2}$, após 3 meses de imersão em água. Os valores das superfícies tratadas com ácido iniciais eram de $53 \mathrm{Kg} / \mathrm{cm}^{2}$ e foram reduzidas para $28 \mathrm{Kg} / \mathrm{cm}^{2}$ 
após 5 meses de imersão; e sugeriram que a união foi devido a combinação química entre um dos constituintes da resina e a matéria orgânica da dentina.

ZANDER $^{207}$, em 1959, fez um breve estudo baseado em experiências clínicas e laboratoriais de alguns pesquisadores da época, sobre a resposta pulpar frente a alguns materiais restauradores. Terminou sua análise concluindo que a reação pulpar à materiais restauradores como o cimento de silicato e cobre provocaram injúrias à polpa e outros materiais não considerados muito danosos, mas quando utilizados sobre a polpa e em grande quantidade poderiam provocar necrose. Entretanto indicou uma base de cimento de hidróxido de cálcio entre o cimento e a dentina. Considerou a resina acrílica como danosa à polpa devido à infiltração marginal que este material sofria. Com relação à restaurações metálicas indicou a condutibilidade térmica como a causa de injúrias à polpa

GOING $^{81}$, em 1960, comparou a penetração marginal de muitos materiais restauradores comuns à clínica, empregando corante de cristal de violeta e iodo radioativo como soluções traçadoras. Cavidades de classe $\mathrm{V}$ foram preparadas em 316 dentes humanos recém extraídos e foram restauradas com amálgama de prata, inlay de ouro fundido, ouro em folha, resina acrílica, cimento de silicato, cimento de cobre, amálgama de cobre, cimento de óxido de zinco e eugenol, cimento de fosfato de zinco ou cimento temporário. Cavidades sem restauração foram utilizadas como controle e comparação. Avaliou também restaurações com um ano na boca, antes da extração, de amálgama de prata, ouro fundido e cimento de silicato, para comparar a penetração marginal ao redor de restaurações recentes e mais antigas. Depois os dentes foram imersos no corante de cristal de violeta e iodo radioativo por 24 horas. Decorrido este período os dentes foram seccionados e várias autorradiografias foram obtidas em condições padronizadas além de serem fotografadas com filme colorido permitindo uma análise comparativa do corante e penetração de isótopos ao redor das restaurações. $O$ autor dividiu suas observações em três partes: 1) observações na permeabilidade de dentina recém cortada; 2) penetração marginal ao redor de novas restaurações 
e 3) penetração marginal ao redor de restaurações antigas na cavidade oral. 0 método de avaliação dos traçadores seguiu um critério de escores préestabelecidos de 0 a 5 . Depois das análises concluiu que a dentina recém cortada e sem restauração foi igualmente permeável ao cristal de violeta e ao iodo (131) .Todas as restaurações apresentaram algum grau de penetração marginal pelo iodo (131). Nas condições que o autor realizou este estudo o ouro em folha, amálgama em folha e cimento de cobre mostraram penetração do isótopo em menos da metade da profundidade das margens cervical e incisal. Inlays de ouro mostraram penetração de isótopo no assoalho da cavidade. Amálgama de prata, cimento de silicato, cimento de óxido de zinco e eugenol e cimento temporário, $O$ isótopo penetrou em toda a dentina. $A$ penetração do corante em todos estes materiais ficou limitada às paredes marginais. $O$ cimento de fosfato de zinco e a resina acrílica tiveram penetração de corante e isótopo até a polpa, à semelhança das cavidades sem restauração. Os amálgamas antigos e as restaurações de cimento de silicato apresentaram menor penetração de corante e isótopo quando comparados com as restaurações novas.

Em 1961, PHILLIPS et al. ${ }^{153}$, avaliaram a adaptação marginal de alguns materiais restauradores (amálgama, cimento de silicato, cimento de fosfato de zinco e resina) depois de vários períodos na cavidade oral. Utilizaram dentes de cães e humanos. Depois de restaurados, os cães foram sacrificados em intervalos de 48 h, 30 e 60 dias e 6 meses. No estudo clínico, realizado em humanos, cavidades de classe $\mathrm{V}$ foram confeccionadas, e os dentes foram extraídos depois de 1 semana, 1 mês e 3 meses. Após as extrações os dentes foram colocados em contato com $\circ \mathrm{Ca}^{45}$ por $24 \mathrm{~h}$. Em ambas as fases do estudo os resultados obtidos foram comparados. Com base nos resultados os autores concluíram que: 1) Inicialmente as margens das restaurações de amálgama foram facilmente penetradas pelo isótopo, mas a infiltração pareceu diminuir com a idade da restauração. $O$ uso de um verniz cavitário aparentemente melhorou o selamento inicial do amálgama; 2) o cimento de silicato apresentou um comportamento variável. Muitos espécimes exibiram uma grande penetração das margens, enquanto outros bem menores 
penetrações. A superfície do material foi permeado pelo isótopo; 3) alguma infiltração foi observada com o cimento de fosfato de zinco, mas em restaurações antigas a infiltração diminuiu; 4) a resina apresentou um bom selamento cavitário no curto período de tempo testado.

Em 1961, GOING; MASSLER ${ }^{83}$, estudaram a influência de bases cavitárias, debaixo de restaurações de amálgama de prata em cavidades de classe $\mathrm{V}$, com a penetração de traçadores radioativos através das margens das restaurações e no interior da dentina. Utilizaram para este estudo 234 dentes recentemente extraídos. Oito forramentos e bases diferentes testados em quatro soluções diferentes de isótopos. A penetração dos isótopos foi avaliada seguindo um critério de escores de 0 a 5 , depois dos dentes serem seccionados ao meio a análise realizada das camadas formadas pelo verniz copal e um forrador de poliestireno etil celulose preveniram a penetração na dentina dos isótopos via margens restauradoras e também diminuíram significantemente a penetração marginal. $\mathrm{O}$ cimento de hidróxido de cálcio bloqueou a penetração na dentina pelos isótopos mas tendeu a concentrar as soluções radioativas. O cimento de óxido de zinco e eugenol diminuiu a penetração na dentina mas não diminuiu o grau de penetração marginal. $O$ cimento de fosfato de zinco aumentou a penetração na dentina assim como a penetração de íons negativos dentro do amálgama; a penetração marginal também foi levemente aumentada. Nas condições do presente experimento, o verniz copal, o forramento de poliestireno etil celulose, e o cimento de hidróxido de cálcio foram efetivos na prevenção de penetração de íons radioativos no interior da dentina e da polpa; cimento de óxido de zinco e eugenol e fosfato de zinco não apresentaram as mesmas características das anteriores.

A capacidade de selamento de seis diferentes materiais restauradores (amalgama, cimento de silicato, cimento de fosfato de zinco e três tipos de resinas restauradoras) colocados em dentes extraídos foi determinada pelo teste de permeabilidade ao $\mathrm{Ca}^{45}$ por SWARTZ; PHILLIPS ${ }^{187}$ em 1961. Depois de restaurados os dentes, a adaptação marginal dos materiais restauradores foi testada 24 horas um mês e seis meses. As margens 
das restaurações de amálgama com 24 horas foram facilmente penetradas pelo $\mathrm{Ca}^{45}$, mas a infiltração diminuiu com 0 aumento da idade das restaurações. Os vernizes cavitários parecem melhorar o selamento marginal destas restaurações. Foi observada infiltração em todas as restaurações com cimento de silicato e cimento de fosfato de zinco. Não foram detectadas mudanças na adaptação seis meses após as restaurações e a sorpção do isótopo foi considerável por estes materiais. $\mathrm{O}$ uso de um forramento cavitário melhorou a adaptação das restaurações de resina, houve um aumento na infiltração quando as restaurações foram submetidas a mudanças térmicas e a magnitude pareceu estar diretamente relacionada às diferenças de temperatura usada.

Em 1964, BARBER; LYELL; MASSLER ${ }^{6}$, avaliaram a efetividade do verniz quando colocados no assoalho e paredes de preparos de classe $\mathrm{V}$ e/ou II e restaurados com amálgama. Depois de preparados os dentes foram divididos em 3 grupos: Grupo I: controle (sem o uso de verniz); Grupo II: verniz somente no assoalho; Grupo III: verniz nas paredes circundantes e assoalho da cavidade. Terminadas as restaurações, as raízes dos dentes foram cobertas com cera para impedir a penetração do isótopo pelo cimento. A seguir os dentes foram imersos em $\mathrm{S}^{35}$ ou $\mathrm{Ca}^{45}$ e seccionados. As secções foram fotografadas e colocadas contra um filme de raio X por 96 horas para produzir as autoradiografias. Os autores obtiveram os seguintes resultados: 1) o Grupo I mostrou penetração em todas as margens da restauração e com grande penetração no interior da dentina e câmara pulpar; 2) no Grupo II ocorreu a penetração nas margens da restauração. Em poucos espécimes, houve penetração no interior da dentina. Entretanto, em todos os dentes, ocorreu redução na penetração do traçador quando comparados com o Grupo I; 3) o Grupo III apresentou completa ausência de penetração do traçador. Com base nestes resultados, os autores concluíram que o verniz copal, quando aplicado em todas as paredes internas do preparo, antes da restauração de amálgama, foi efetivo na prevenção de penetração marginal de íons e traçadores moleculares. 
Em 1965, PICKARD; GAYFORD ${ }^{154}$, fizeram uma revisão da literatura sobre a microinfiltração em restaurações de amálgama, assim como descreveram técnicas para avaliar "in vitro" quantitativamente a infiltração marginal nas restaurações de amálgama. Relataram técnicas da literatura que utilizam ar pressurizado, bactérias, penetração de corantes e isótopos radioativos. Citaram que o método de penetração de corante possui a vantagem de favorecer avaliação em toda a periferia da restauração, entretanto com a desvantagem de permitir que uma grande infiltração em um determinado ponto nas proximidades marginais possa mascarar uma pequena infiltração na interface. Outro fator negativo deste método seria a impossibilidade de avaliar o comportamento de uma mesma amostra em períodos diferentes, uma vez que esta é destruída durante os testes. Avaliaram ainda, diferentes meios de armazenamento dos espécimes e concluíram que, para testes de microinfiltração em restaurações de amálgama, o armazenamento em saliva não é indicado por possuir uma alta viscosidade e componentes orgânicos e inorgânicos não presentes em testes laboratoriais. Estas análises levaram os autores a concluir que, "in vitro", os produtos de corrosão e depósitos bacterianos da saliva artificial obstruem as vias de penetração do corante, impedindo uma correta avaliação da capacidade de selamento marginal do material restaurador. Afirmaram, também que a infiltração nas restaurações mais antigas de amálgama é mínima, provavelmente devido ao depósito de produtos de corrosão ou de materiais orgânicos na interface dente/restauração.

Uma comparação de propriedades físicas de quatro resinas restauradoras (Servitron, Bonfil, Mer-Don 7 e Addent) foi apresentada em 1966, por PETERSON; PHILLIPS; SWARTZ ${ }^{152}$. As resinas foram comparadas com relação à dureza, resistência à abrasão, ponto de deformação sobre compressão, solubilidade, absorção de água, estabilidade de cor, resistência a manchas, adesão à estrutura dental e adaptação marginal. Esta investigação demonstrou certas diferenças entre os vários tipos de resinas estudadas. Nenhum dos materiais provou ser superior aos outros com relação a todas as propriedades testadas. Para os testes de infiltração marginal preparos de Classe $\mathrm{V}$ foram realizadas em dentes humanos extraídos. 15 minutos depois 
de inseridas as resinas, os dentes foram estocados em água e polidas depois de 24 horas. Oito restaurações para cada série foram avaliadas depois de 24 horas, 1 mês e 3 meses. $\mathrm{O}$ traçador da infiltração marginal foi o $\mathrm{Ca}^{45}$, onde os dentes permaneceram imersos por duas horas, e a penetração foi detectada por meio de autoradiografias preparadas de secções longitudinais dos dentes. A ciclagem térmica foi utilizada para simular o ambiente oral, baseados em estudos "in vivo" as temperaturas utilizadas pelos autores foram de $15^{\circ} \mathrm{C}$ e $45^{\circ} \mathrm{C}$ em um grupo e em outro grupo $0^{\circ} \mathrm{C}$ e $60^{\circ} \mathrm{C}$ e os dentes permaneceram 30 segundos em cada banho. A avaliação da infiltração foi realizada com 10, 50 e 100 ciclos. Os resultados demonstraram uma variação muito grande do padrão de infiltração das várias resinas testadas. Os espécimes ciclados entre $15^{\circ} \mathrm{C} \mathrm{e}$ $45^{\circ} \mathrm{C}$ receberam infiltração semelhante àqueles que permaneceram à temperatura constante. Entretanto, uma grande penetração foi notada quando o número de ciclos aumentou de 10 para 100. Um substancial aumento na penetração do isótopo foi notado também, quando a variação de temperatura foi de $60^{\circ} \mathrm{C}$, e novamente quanto maior o número de ciclos, maior a infiltração marginal. Estes dados indicaram que, em testes de ciclagem térmica, as variações usadas são tão importantes quanto ao número de alterações de temperatura empregadas. Os autores concluíram que quanto mais moderada a variação de temperatura, mais representativa é das condições reais às quais a restauração é exposta na cavidade bucal. Os autores concluíram também que ocorreram certas diferenças entre os vários tipos de materiais restauradores testados e nenhum deles mostrou ser superior ao outro com relação a todas as propriedades testadas.

Uma técnica simplificada para testar e classificar microinfiltração ao redor de restaurações foi apresentada por CHRISTEN; MITCHELL ${ }^{42}$, em 1966. Oitenta e sete cavidades de classe $\mathrm{V}$ foram preparados em 32 incisivos bovinos. As cavidades foram divididas em quatro grupos e restaurados com: Grupo 1: amálgama, Grupo 2: amálgama + verniz, Grupo 3: guta-percha e Grupo 4: óxido de zinco e eugenol. Os dentes restaurados foram imersos em fluorceína e rodamina $B$ por período de 5, 12 minutos e 1 hora. A seguir, os dentes foram seccionados e analisados em luz ultra-violeta. Com uma exceção, 
os corantes mostraram infiltração marginal satisfatoriamente. As restaurações de amálgama com 24 horas mostraram infiltração considerável. Amálgama associado ao verniz cavitário mostrou infiltração reduzida. Todas as restaurações de guta-percha mostraram muita infiltração. $O$ corante fluorescente testado pelos autores não demonstrou microinfiltração ao redor de restaurações de óxido de zinco e eugenol porque o cimento apagou a fluorescência. $O$ esmalte bovino foi impermeável aos corantes fluorescentes testados. A fluorceína é um corante não tóxico, e apresenta bastante contraste.

DOLVEN $^{58}$, em 1966, mediu a espessura do material de forramento, usando luz ultravioleta e refletida e o efeito dos forramentos na penetração marginal com $\mathrm{Ca}^{45}$. Utilizou dentes humanos extraídos. O material escolhido foi o Copalite, que foi feito com corantes fluorescentes. Dividiu os dentes em três grupos de 20 dentes cada. $O$ grupo I não recebeu forramento e foi o grupo controle; o grupo II recebeu o forramento cobrindo somente a dentina; o grupo III estendeu o verniz até o cavo-superfícial das cavidades. A influência do forramento na infiltração marginal foi avaliado com autoradiografias, utilizando escores de 0 a 3 . De posse dos resultados o autor concluiu que os três grupos mostraram uma convincente tendência de redução da infiltração marginal com forradores. O verniz Copalite mostrou-se efetivo no selamento dos túbulos, e estava presente nos túbulos. Ao investigar a espessura do filme, mostrou que a camada era descontínua, mas interferiu no sucesso do material. A espessura do filme foi de 3 a $9 \mu$. A teoria da difusão de cristais foi discutida e a extensão da difusão na dentina questionada como uma medida válida para quantificar a infiltração marginal, e sugeriram uma outra teoria, a da difusão direta via lumen túbular.

ROUDHOUSE; WEISS; LEONARD ${ }^{171}$, em 1967, procuraram obter explicações para falhas das restaurações em testes laboratoriais repetindo condições comuns clinicamente. Quiseram também determinar como alguns compósitos novos, na época, poderiam prevenir "a dor após amálgama" e as cáries secundárias, fenômenos costumeiramente atribuídos à infiltração ao redor das restaurações. Utilizaram para isto dentes bovinos e humanos. 
Preparos cavitários de classe $\mathrm{V}$ foram confeccionados e restaurados com diferentes materiais restauradores; cimento de silicato com forramento de fosfato de zinco e sem; resina acrílica com e sem forramento e amálgama com verniz. Os dentes foram divididos em 3 grupos diferentes que tiveram como variável os operadores, cada grupo foi realizado por um operador diferente. Depois de polidas, as restaurações foram submetidas a diferentes tratamentos térmicos e submersas em diferentes corantes: fucsina básica, metil violeta, ciomotrope $2 \mathrm{R}$, fucsina básica em poprileno glicol e metil violeta em poprileno glicol. Em seguida foram seccionados em três ou quatro secções e observadas em microscópio, e os dados avaliados estatisticamente. Com base nesta análise, os autores concluíram que a infiltração ou penetração ao redor das restaurações depende de uma série de fenômenos e não de um apenas. Os testes de laboratório são influenciados pelo operador. A infiltração é também influenciada pelo material utilizado, assim como é determinada pela morfologia da cavidade e dos dentes, e é fortemente influenciada pelas condições intraorais não representadas em experimentos "in vitro".

Em 1967, ELLIS; BROWN ${ }^{64}$, estudaram a possibilidade de se determinar "in vitro" uma técnica especificamente cariogênica para estudar a infiltração na interface dente/restauração, e o emprego deste método para avaliar restaurações de amálgama com ou sem material para forramento, na prevenção ou inibição (ou ambos) "in vitro" de cáries ao redor de restaurações. Foram confeccionadas duas cavidades oclusais em 28 terceiros molares. Essas cavidades foram restauradas com amálgama, sendo uma delas forrada com verniz e a outra não. Os dentes restaurados foram expostos a efeitos de crescimento bacteriano por 12 ou 16 semanas. Ao final deste período, os dentes foram fixados em formalina a $10 \%$ e secções de $250 \mu \mathrm{m}$ foram preparadas. Essas secções foram fotografadas e coradas pelo método modificado de Brown e Brenn. A técnica utilizada promoveu um meio efetivo de detectar lesões cariosas ao redor de restaurações. Os resultados demonstraram que restaurações de amálgama forradas foram menos suscetíveis à produção de lesões cariosas do que as restaurações de 
amálgama não forradas. E que as lesões cariosas foram mais facilmente detectáveis após 16 semanas.

Argumentando que a falta de um método mais objetivo para avaliar os resultados apresentados pelos diversos autores, em trabalhos de infiltração marginal constatada por auto-radiografias, poderia ser uma das causas para a diversidade dos resultados obtidos, RUSSO ${ }^{173}$, em 1968, apresentou um novo método de avaliação, procurando eliminar uma das causas de erro de interpretação. Para tanto, intensificou, com o auxílio de raios $\mathrm{X}$, as auto-radiografias obtidas e montou novamente os espécimes diretamente sobre películas radiográficas, obtendo radiografias semelhantes àquelas que sofreram ação do radioisotopo, mas sem a imagem radiolucente provocada por este último. A seguir projetou as radiografias e posteriormente as autoradiografias intensificadas correspondentes ao caso, obtendo desenhos destas áreas de infiltração, sendo que as últimas, medidas com o auxílio de aparelhos precisos (planímetro de compensação polar e curvímetro). Os resultados, o autor, trata estatisticamente e segundo ele, permite uma discussão mais segura dos resultados. Depois de ter realizado várias experiências com esta técnica, o autor considerou válido concluir que, mesmo não sendo totalmente isento de erros, o método foi mais seguro do que os descritos até a presente data, na literatura especializada sobre $o$ assunto.

GOING; MYERS; PRUSSIN ${ }^{84}$, em 1968, idealizaram um novo método quantitativo para medir infiltração ao redor de restaurações para refletir não somente a total distribuição do corante na região da restauração, mas também para oferecer um meio prático de testar selamento marginal de restaurações "in vivo". Para isto preparam cavidades em 120 dentes humanos, sendo 108 "in vitro" e 12 "in vivo". Utilizaram para restauração das cavidades algumas marcas de resina, silicato e materiais provisórios, todos manipulados de acordo com as instruções do fabricante. Os dentes restaurados "in vitro" foram cobertos com cera utilidade para o selamento do foramem apical e todas as superfícies do dente, exceto a região da restauração. Os dentes restaurados "in vivo" também foram selados com cera. Com o dique de borracha em 
posição, uma coroa de celuloide foi adaptada ao dente e uma janela ligeiramente maior que a restauração foi aberta na coroa, a superfície interna foi coberta com cera utilidade. A solução corante utilizado foi o $\mathrm{Mn}\left(\mathrm{NO}_{3}\right)_{2}$ a $50 \%$. Os espécimes "in vitro" ficaram imersos por 1 hora, os espécimes "in vivo" foram isolados por uma capa de latex bem adaptada na região cervical e por intermédio de uma seringa o corante foi injetado em seu interior recobrindo os dentes por 1 hora também. Depois de realizado os procedimentos de penetração do corante os espécimes foram seccionados em 3 locais: o centro das restaurações, a área marginal e o restante subjacente da dentina. Baseados nos resultados concluíram que a infiltração marginal ao redor das restaurações "in vitro" variaram entre 1 e $87 \mu \mathrm{g}$. As restaurações de cimento de silicato obtiveram geralmente maiores valores de penetração de corante do que as de resina e cimento temporário Os menores valores indicaram um melhor selamento inicial "in vitro". O desenvolvimento de um isolador de latex permitiu testes "in vivo" para microinfiltração sem causar incômodo para o paciente. Em todos os 12 testados, a microinfiltração foi maior "in vivo" do que "in vitro". A maior diferença foi encontrada com os materiais temporários, e a menor com 0 cimento de silicato. Ressaltaram, ainda que o desenvolvimento de uma técnica quantitativa para medir infiltração permitiria futuros estudos para determinar a magnitude da infiltração do corante ou isótopo utilizado.

Em 1969, LEE; SWARTZ; SMITH ${ }^{110}$, realizaram um estudo comparando as propriedades físicas de quatro resinas. Os materiais testados foram:- Addent 12, Addent 35, Dakor e Adaptic. Duas gotas do catalizador do Addent foram utilizadas para o preparo dos espécimes, assim todos os materiais tiveram o mesmo tempo de gel, 60 a 90 segundos. Todos os materiais foram misturados por 30 segundos. As propriedades físicas testadas dos materiais foram:- sorpção de água, solubilidade, força de compressão, força de tensão, resistência flexural e módulo de flexão, dureza, contração de polimerização, coeficiente de expansão térmica linear, resistência ao desgaste, translucidez, manchamento, estabilidade de cor e acabamento de superfície. Detectaram diferenças significativas nas propriedades mecânicas e físicas dos materiais testados. Todos eles pareceram ser superiores em muitos aspectos 
aos materiais restauradores de polimetilmetacrilato convencionais e também aos silicatos. Somente o Adaptic é indicado pelo fabricante para uso em dentes anteriores e posteriores, neste estudo, os resultados dos testes de translucidez e resistência à compressão podem substanciar essas afirmações. Os autores citaram ainda que devido à grande variação das propriedades encontradas para os materiais testados, o clínico deveria considerar cuidadosamente vários fatores ao fazer a escolha como, irritação pulpar, facilidade de manuseio, custo por restauração, validez, matiz e cor, mistura, e estética.

TANI; BUONOCORE ${ }^{189}$, em 1969, investigaram a infiltração marginal do corante fucsina básica nos seguintes materiais restauradores:Serviton, Bonfil, Addent-35, Dakor e um cimento de silicato. Vários fatores que podem afetar a infiltração marginal foram isolados e estudados, como o tempo de estocagem em água, temperatura de ciclagem, formato e profundidade do preparo cavitário, e retenção com pino. Utilizaram dentes bovinos extraídos, onde confeccionaram preparos de classe $\mathrm{V}$ padronizados. Com exceção do silicato as restaurações foram polidas com discos depois de 20 minutos de inseridas, não foram cobertas com verniz e foram estocadas em água à temperatura ambiente por 24 horas, 1 e 3 meses. O cimento de silicato depois de restaurar as cavidades foi estocado por 20 minutos e polidos 24 horas mais tarde. Para averiguar a influência da mudança de temperatura na infiltração marginal, 5 dentes de cada período de tempo, de todos os materiais foram ciclados 25 vezes em dois banhos de água à $4^{\circ} \mathrm{C}$ e $60^{\circ} \mathrm{C}$ permanecendo 1 minuto em cada banho. Depois da imersão, os dentes foram cobertos com cera utilidade e imersos em solução de fucsina básica a 0,5\% com pH de 5, 9 por 24 horas. Assim que foram removidos do corante os dentes sofreram várias secções no sentido axial e a secção que apresentou maior grau de infiltração de cada dente foi utilizado e classificado segundo escores pré estabelecidos de 0 a 4. Para estudar o efeito do formato cavitário na infiltração marginal, cavidades foram preparadas em forma de taça, expulsivas e retentivas. Um pino de fricção foi enserido na base de cada cavidade usando uma técnica padronizada e o pino foi cortado abaixo das margens cavitárias com o auxílio de uma broca. Depois de 24 horas de imersão em água, os espécimes foram 
avaliados. Sevriton e Dakor mostraram menor infiltração marginal no período de imersão de 24 horas. A estocagem das restaurações em água por 3 meses antes da exposição ao corante, geralmente resultou em aumento da infiltração, exceto para Addent que diminuiu e para o Dakor que não sofreu mudança. Todos os materiais mostraram o máximo de infiltração depois da ciclagem térmica. Não houve diferença na infiltração marginal quando se avaliaram os critérios da profundidade e do formato cavitário. Segundo os autores, a espessura do esmalte nas margens da cavidade pode ser um fator mais determinante na infiltração, do que a profundidade em dentina. $O$ uso de pino em cavidades retentivas geralmente resultou em menor infiltração do que as cavidades em forma de taça e expulsiva para todos os materiais.

LOUISELLE et al. ${ }^{114}$, em 1969, relataram a grande variedade de testes realizados em laboratório para investigar infiltração ao redor de restaurações; dentes humanos ou animal, extraídos, corantes coloridos, radiosótopos e bactérias. E questionaram se a remoção do órgão dental do organismo não poderia ter efeito sobre a penetração marginal. Avaliaram comparativamente, neste estudo, a infiltração marginal ao redor de restaurações de amálgama em cavidades classe $V$ em testes "in vivo" e "in vitro", utilizando como corante a solução de fluoreceina a $2 \%$. Com base nos resultados obtidos o teste "in vitro" apresentou uma infiltração bem mais severa tanto em humanos (média 2,5) como em hamster $(2,3)$, comparados com os resultados "in vivo" de humanos $(0,2)$ e hamster $(0,2)$. Sugeriram que os testes de infiltração marginal deveriam ser determinados "in vivo", pois são mais aproximados do normal.

GUSMAN; SWARTZ; PHILLIPS ${ }^{88}$, em 1969, estudaram os efeitos do estresse térmico na adaptação marginal de quatro materiais submetidos às mesmas condições. O efeito de outras variáveis, como a idade das restaurações e a influência do verniz cavitário sob o amálgama também foram investigados. Preparos cavitários de classe $\mathrm{V}$ foram confeccionados no terço médio da face vestibular de dentes humanos extraídos. Os preparos cavitários foram restaurados com amálgama, cimento de silicato, resina e com resina 
epóxica. Nas restaurações de amálgama, uma parte dos espécimes foi forrado com verniz e outra não. A adaptação marginal de cada restauração foi medida depois de uma semana, um mês, e três meses de estocagem em água, submetendo os dentes restaurados em uma solução radioativa de $\mathrm{Ca}$. O grau de penetração de isótopo ao longo da interface dente/restauração foi medida por meio de autoradiografias. Foram utilizadas 27 restaurações para cada material restaurador testado em cada intervalo de tempo. Nove restaurações não foram submetidas a ciclos de temperatura, e foram utilizados como controle. Nove foram submetidas à 50 ciclos térmicos, e os nove remanescentes submetidos a 500 ciclos. Os banhos foram de $15 \pm 10^{\circ} \mathrm{C}$ e $45 \pm$ $10^{\circ} \mathrm{C}$, e o tempo de cada banho de 30 segundos. Depois da ciclagem, os dentes foram expostos à solução de isótopo e a seguir seccionados longitudinalmente e analisados. Baseados nos resultados obtidos, os autores concluíram que a infiltração ao redor das restaurações de amálgama com uma semana de idade foi maior quando submetidas a 500 ciclos, os espécimes com três meses exibiram um melhor selamento e não foi afetado pela ciclagem térmica. As restaurações de amálgama que apresentaram verniz forrador, mostraram pouca ou nenhuma penetração marginal em todos os períodos testados, e a qualidade destas restaurações não foram afetadas pelo estresse térmico. O cimento de silicato e as duas resinas apresentaram um considerável grau de eficácia até o período de três meses neste estudo. A adaptação marginal não foi prejudicada pela magnitude do estresse térmico empregado pelos autores neste estudo.

Em 1970, RETIEF ${ }^{159}$, por meio de uma extensa revisão da literatura, analisou as várias pesquisas que tentaram produzir um material restaurador que se unisse adequadamente a estrutura dentária e previnisse infiltração marginal. Fez considerações sobre a dificuldade em se obter adesão intra-oralmente devido à natureza destrutiva do ambiente oral. Incluiu como problemas para esta adesão a heterogeneidade da superfície do esmalte e da dentina, o ambiente aquoso que faz com que o adesivo seja capaz de se unir ao dente sem que a água interfira nas suas propriedades, a rugosidade dos preparos cavitários, possibilitando a formação de bolhas de ar reduzindo a área 
de contato entre o adesivo e o dente, representando locais de concentração de estresse e de pouca resistência adesiva, a presença de "debris" na superfície, as forças mastigatórias, as variações rápidas do $\mathrm{pH}$ oral, as variações térmicas e o potencial tóxico do próprio material foram os aspectos enfocados e considerados para determinar as características do adesivo dentinário ideal. Segundo o autor, este adesivo ideal deveria apresentar as seguintes características, produzir uma união permanente com o esmalte e a dentina, polimerizar-se à temperatura bucal com o mínimo de contração, minimizar a expansão ou sorpção de água, ser eficientemente forte para resistir às forças mastigatórias, possuir o mesmo coeficiente de expansão térmica da estrutura dentária, não ser tóxico à polpa e aos tecidos gengivais e, resistir a qualquer tipo de degradação na cavidade oral.

BROWN; JACOBS; THOMPSON ${ }^{25}$ em 1972, descreveram alguns resultados do efeito do estresse térmico em dentes, especialmente os resultados da fadiga térmica dos dentes. Para isto dentes humanos e bovinos foram submetidos a uma ciclagem térmica em uma máquina que continha água em temperaturas de 140 e $90^{\circ} \mathrm{F}$, simulando as mudanças encontradas na boca, cada banho foi de 30 segundos. A raiz dos dentes foram cobertas com resina epóxica para simular as propriedades térmicas de proteção da gengiva. Antes de começarem os testes, os dentes foram submetidos a uma inspeção visual para tomarem conhecimento de trincas e fraturas pré-existentes. Utilizaram um corante fluorescente para detectar estas trincas antes dos testes e durante os intervalos de inspeção do teste. Os resultados das análises mostrou que os dentes bovinos são mais susceptíveis a trincas e fraturas do que os dentes humanos. Pequenas fraturas em dentes humanos aumentaram muito depois de 2000 ciclos enquanto os bovinos com 1/3 destes ciclos já exibiram o mesmo fenômeno. Concluíram que a fadiga térmica causa um estresse suficiente para deteriorar dentes humanos e bovinos, e que diferenças térmicas de $50^{\circ} \mathrm{C}$, que são comumente vivenciadas clinicamente, criam um alto estresse, suficiente para causar fraturas ao esmalte depois de 1000 ciclos. Finalizaram ainda dizendo que se uma pessoa realiza 10 mudanças de temperatura por dia, no 
final de um ano totalizaram-se 3.650 ciclos, o que indica que fraturas seriam causadas no esmalte dentinário.

Em 1972, GOING ${ }^{82}$, apresentou um resumo sobre microinfiltração ao redor de restaurações e tentou responder duas questões práticas como: 0 que as pesquisas nesta área têm contribuído para a prática do dentista e qual é o futuro dos estudos da microinfiltração. Fez uma revisão dos estudos sobre microinfiltração mostrando, muitas técnicas engenhosas desenvolvidas para estudar permeabilidade marginal da interface dente e restauração. Todos estes estudos enfatizaram o fato de que as margens das restaurações não são fixas, inertes e impenetráveis. Discorreu sobre vários métodos de medir a microinfiltração como isótopos radioativos, o qual considerou ser um método bastante usado e aceito como um traçador para demonstrar a incapacidade de selamento dos materiais restauradores e, que a maior crítica para o uso deste traçador para estudos de infiltração marginal que o autor encontrou, foi o fato de que a interpretação das autoradiografias permite apenas um julgamento qualitativo da profundidade e o caminho de penetração do traçador. Por meio da literatura revisada, afirmou ser o uso dos corantes um dos métodos mais antigos e freqüentemente utilizados para o estudo de microinfiltração. Os corantes mais utilizados são: eosina, azul de metileno, metil violeta, crismatoxilina, fucsina básica, cromotrope $2 \mathrm{R}$, cristal violeta, e fluoresceina. Considerou os corantes fluorescentes bastante úteis pois apresentam um grande contraste com a estrutura dentária, permitindo uma visualização bastante fácil. Com relação aos testes que utilizam a penetração de bactérias, considerou-os mais empregados clinicamente porque podem relatar o processo carioso e cárie recorrente, e os resultados também são descritos com bases qualitativas. Citou como vantagens do método que utiliza ar pressurizado para estudar microinfiltração como sendo um método muito preciso e os dados são quantificativos, o fator limitante deste método é que somente pode ser realizado "in vitro" e não simula condições presentes na cavidade oral. Os estudos que medem a percolação marginal, submetem os dentes extraídos a mudanças de temperatura ocorridas na boca para quantificar a abertura e o fechamento das margens da restauração. O microscópio eletrônico de 
varredura é um meio de observação visual direta das margens do preparo cavitário, este estudo tem profundidade de foco e aumenta a área a ser examinada. As limitações deste método se restringem ao método de avaliação dos dentes fora do ambiente oral e não orienta a difusão e penetração como outros métodos. Os dados analisados das fotomicrografias são baseados na medida dos tamanhos das fissuras entre a restauração e o dente. $O$ uso da análise por ativação de neutron representa algum progresso no entendimento do fenômeno da microinfiltração. Esta técnica proporciona um meio de estudar o processo de difusão na boca e permite acumular dados para ser quantificado e reproduzido. Uma limitação desta técnica reside no fato de que os dentes têm que ser extraídos para a irradiação e análise imediatamente depois do período "in vivo", portanto somente dentes com problemas periodontais são avaliados. Além do custo deste estudo ser relativamente alto quando comparado a outras técnicas. Estes testes demonstraram aos clínicos que os materiais restauradores não possuem uma união química à estrutura dental e alertam os clínicos para o fato da microinfiltração ser inerente aos materiais restauradores comumente usados. Por este motivo, os clínicos devem se esforçar para compensar as deficiências dos materiais usando-os com prudência, disciplina e técnicas corretas. Quanto ao futuro dos métodos para pesquisar infiltração, o autor relatou que estes deveriam ser aplicados "in vivo" e que pudessem ser facilmente duplicados. Enfatizou ainda que até a influência do ambiente oral no mecanismo de difusão ser melhor entendido, pequenos avanços podem ser antecipados em pesquisas fora da boca.

ASMUSSEN; JORGENSEN ${ }^{4}$, em 1972, mediram a contração de polimerização e a expansão devido à absorção de água de alguns materiais plásticos considerando estes fatores como uma das maiores dificuldades na aplicação clínica destes materiais. Os materiais investigados foram: Adaptic, Addent XV, Blendant, Concise, D.F.R., Palakav, Palakav encapsulado, TD71, Palavit 55, Sevritron simplificado e Swendon. Os materiais foram colocados em preparos cavitários cilíndricos em dentes humanos extraídos. As mudanças dimensionais dos materiais restauradores foram medidas em um microscópio, e esta investigação foi realizada sempre em temperatura ambiente de $37^{\circ} \mathrm{C}$. As 
restaurações foram examinadas logo após o endurecimento inicial ou depois de variados períodos de imersão em água. Imediatamente depois do endurecimento inicial o microespaço marginal em esmalte e dentina foi observado. O polimento das restaurações logo após o endurecimento inicial resultou em áreas de fratura no esmalte de 20-40 $\mu \mathrm{m}$. Quando as restaurações foram estocadas em água, a largura dos "gaps" marginais reduziu. Para algumas marcas de resina os "gaps" foram completamente fechados em 32 dias. O polimento das restaurações depois de fechados os "gaps" da contração de polimerização resultou em um mínimo de fraturas nas margens do esmalte.

BOEHM $^{16}$, em 1972, realizou um estudo experimental na tentativa de definir a temperatura na cavidade oral, do dente humano durante a abertura da boca na respiração. Idealizou um aparato para medir esta temperatura e o acoplou a superfície lingual dos incisivos e caninos. Foram feitas medidas da variação de temperatura do ambiente e do coeficiente de transferência de calor. As variações foram pequenas devido a proteção, exceto nos arredores dos incisivos e caninos. Como resultados da evaporação, a temperatura durante a inalação foi significantemente mais baixa do que a temperatura do dispositivo de medir a temperatura quando seco em muitas situações. Isto dependeu da umidade do ambiente e foi mais severa em ocasiões de pouca umidade. Durante a exalação, a temperatura do ambiente aproximou à temperatura do corpo. Sobre estas circunstâncias, pequenas trincas nos dentes foram formados. Os resultados deste estudo mostraram que a temperatura pode ser afetada consideralvemente pela temperatura ambiente, umidade ambiente, e pouca umidade da cavidade oral.

Em 1973, GRIEVE ${ }^{86}$, descreveu uma pesquisa na qual lesões cariosas artificiais foram produzidas ao redor de restaurações de amálgama em dentes extraídos e expostos a uma gelatina acidificada. Utilizou 70 pré-molares extraídos, realizou preparos cavitários de classe $\mathrm{V}$ e os dividiu em três grupos que se diferenciaram pelo tratamento cavitário antes da inserção do amálgama. O grupo 1 recebeu uma camada de verniz copal, o grupo 2 uma camada de Tubulitec (verniz contendo hidróxido de cálcio óxido de zinco e 
monofluorfosfato de cálcio) e o grupo 3 nenhum forramento prévio. Após restaurados, os dentes foram estocados por 24 horas em água a temperatura ambiente e a seguir cobertos com uma camada de verniz exceto $0,5 \mathrm{~mm}$ ao redor das restaurações. Depois disto então, os dentes foram novamente estocados só que em uma gelatina acidificada por 24 horas. Esses dentes foram então seccionados e observados em um microscópio de luz polarizada. A análise mostrou uma extensa cárie artificial ao redor das restaurações que possuíam verniz como forrador, entretanto bem menores do que as do grupo que não recebeu verniz como forramento. De posse dos resultados o autor conclui que este estudo sugere que o uso de verniz cavitário reduz a extensão da lesão cariosa ao redor de restaurações de amálgama, mas não a previne totalmente. E o uso de um verniz contendo flúor não mostrou vantagens sobre o verniz copal.

O propósito do estudo de ASMUSSEN $^{2}$, em 1974, foi de investigar a relação entre redução de temperatura e o tamanho dos "gaps" marginais assim como, estudar o efeito de uma elevação inicial da temperatura na formação de "gaps" durante o subseqüente resfriamento da restauração de resina. As resinas utilizadas foram as seguintes: Adaptic (A); Blendant (B); Concise (C); Optow (D); Sevriton Simplified (E); e Swedow (F). As restaurações foram realizadas em dentes humanos extraídos. O tempo de estocagem em água dos dentes antes do polimento foi de 1, 8 ou 64 dias para a marca E, e 8 ou 64 dias para as marcas A,B,C,D e F. Cinco restaurações de cada marca foram examinadas com o polimento realizado depois de 1 ou 8 dias, $10 \mathrm{com}$ o polimento realizado depois de 64 dias. Imediatamente depois do polimento, a área marginal das restaurações foi inspecionada por um microscópio e em todos os casos foi confirmado que o "gap" entre a restauração e o dente foi fechado. A inspeção foi feita em um termostato em temperatura ambiente à $37^{\circ} \mathrm{C} \pm 11^{\circ} \mathrm{C}$ e por aproximadamente 2 minutos. Depois disto as restaurações foram sucessivamente colocadas em água a $23 \pm 1^{\circ} \mathrm{C}$, $15 \pm 1^{\circ} \mathrm{C}, 10 \pm 1^{\circ} \mathrm{C}$ e $2+1^{\circ} \mathrm{C}$. Depois de cada temperatura os microespaços foram medidos e expressos em porcentagem do diâmetro da cavidade. A seguir os dentes restaurados foram colocados em água a $50 \pm 1^{\circ} \mathrm{C}$ por 2 minutos $\mathrm{e}$ 
depois novamente em água a $60 \pm 1^{\circ} \mathrm{C}$ por 2 minutos. Depois de cada aquecimento o "gap" marginal foi medido em água a $2^{\circ} \mathrm{C}$. "Gaps" com 0,4 $\mu \mathrm{m}$ foram medidos. Depois de 64 dias de absorção de água as restaurações $A, B, C, D$ e $E$ resfriados de $37^{\circ} \mathrm{C}$ a $10^{\circ} \mathrm{C}$ não formaram "gaps". Com a marca $F$ os "gaps" ao redor das restaurações apareceram quando foram resfriados a $23^{\circ} \mathrm{C}$. O autor concluiu que as restaurações podem ser resfriadas a certas temperaturas sem formar "gaps" marginais. O tamanho dos "gaps" a $2^{\circ} \mathrm{C}$ foi menor quando previamente aquecidas à $50^{\circ} \mathrm{C}$. O aquecimento a $60^{\circ} \mathrm{C}$ aumentou o "gap" a $2^{\circ} \mathrm{C}$ somente nas resinas não compostas.

RAFEI; MOORE ${ }^{156}$, em 1975, avaliaram o selamento marginal das resinas compostas Nuva-fil e Adaptic. Para isto confeccionaram cavidades de Classe V na superfície vestibular e lingual de 50 incisivos extraídos, superiores e inferiores. Os materiais foram utilizados de acordo com as instruções do fabricante. Depois de restaurados, os espécimes foram submetidos a ciclagem térmica e corantes, foram imersos em banhos de água a $60^{\circ} \mathrm{C}$ por um minuto e imediatamente transferidos a uma solução de corante azul a $2 \%$ por um minuto à $40^{\circ} \mathrm{C}$. Este processo se repetiu por 25 vezes. Terminada a ciclagem, os dentes foram seccionados no centro das restaurações. Avaliados por meio de um microscópio e classificados segundo escores de 0 a 4 . Os resultados mostraram que $28 \%$ das restaurações com Adaptic mostraram grau 0 de penetração e os espécimes remanescentes variaram na profundidade de penetração do corante; e todas as cavidades restauradas com Nuva-fil apresentaram grau 0 de penetração do corante.

Em 1975, ASMUSSEN ${ }^{3}$, investigou a possibilidade da relação entre a composição da resina composta e a contração de polimerização parede/parede. As marcas investigadas continham BISGMA diluído com várias quantidades de um ou dois monômeros de baixa viscosidade. A concentração parede/parede foi medida microscopicamente, a medida foi do máximo da largura da fenda na dentina da cavidade em dentes humanos extraídos. Uma correlação positiva entre a largura da fenda e a quantidade de monômeros diluídos foi encontrado pelo autor, com resinas compostas comerciais, com 
resinas não compostas e com uma resina experimental. A adição de $75 \%$ em peso de uma partícula inorgânica misturada ao monômero similar àqueles encontrados em compósitos comerciais não afetaram a largura da fenda. $O$ autor concluiu que a composição da fase orgânica é de importância primária para o tamanho da contração parede/parede de resinas compostas.

Por meio de uma revisão de literatura, KIDD ${ }^{104}$, em 1976, definiu a microinfiltração como a passagem de bactérias, fluídos, moléculas ou íons entre as paredes cavitárias e o material restaurador. Como conseqüência da microinfiltração citou problemas como cárie secundária, descoloração marginal, hipersensibilidade pós-operatória, alterações pulpares e biocompatibilidade dos materiais. Afirmou o fato de ainda não existir um material restaurador capaz de aderir quimicamente à superfície dentária, proporcionando um selamento perfeito capaz de resistir à umidade da cavidade oral e às constantes mudanças térmicas que são submetidos intra-oralmente. Muitas técnicas têm sido desenvolvidas com o intuito de se estudar a permeabilidade marginal da interface dente/restauração e, o resultado destes estudos enfatizam que as margens das restaurações não são fixas, inertes e com bordas impenetráveis, mas sim, um microespaço que permite o tráfego constante de íons e moléculas. Com relação às restaurações de amálgama, a autora relata que o verniz cavitário aplicado previamente ao material restaurador é efetivo em reduzir a microinfiltração inicial. Ao discorrer sobre as resinas compostas e acrílicas, relatou que a termociclagem parece destruir rapidamente o selamento inicial, embora nesta época existissem poucos estudos na literatura sobre o comportamento das resinas compostas. Admitiu a diferença de comportamento dos materiais provavelmente à diferença no seus coeficientes de expansão térmica. Concluiu ainda, que a avaliação da microinfiltração, com as diversas técnicas existentes, se faz necessária para prognosticar o desempenho dos materiais restauradores no ambiente oral.

BRADEN; CAUSTON; CLARKE $^{19}$, em 1976, relataram as medidas por peso, da sorpção de água e da evaporação de água de vários materiais resinosos restauradores. Para determinar a quantidade de água 
absorvida e evaporada, os espécimes foram pesados até que se chegasse a uma medida constante. Os autores concluíram que a medida do coeficiente de difusão da água nos materiais resinosos mostrou que o mesmo diminui com o aumento da concentração de água, o que leva a um equilíbrio natural. Portanto, o processo de difusão em compósitos restauradores segundo os autores, parece ser um processo controlado.

Em 1976, GALAN JR; MONDELLI; CORADAZZI ${ }^{74}$, avaliaram a capacidade de selantes no selamento das margens de restaurações composta "in vitro", utilizando duas resinas compostas e seus respectivos selantes. Preparos cavitários de classe $V$ foram realizados na face vestibular de 50 caninos e, pré-molares humanos extraídos. Depois de preparados, os dentes foram separados dentro de cinco grupos e cada um com 2 subgrupos de cinco dentes cada. Cinco subgrupos foram restaurados com Concise e os outros cinco subgrupos com Nuva-Fil. O grupo 1 não recebeu condicionamento; 0 grupo 2 foi condicionado e restaurado com Concise ou Nuva Fil; no grupo 3, dois milímetros do esmalte vestibular foram condicionados com ácido e os selantes de Concise e Nuva-seal foram aplicados; no grupo 4 dois milímetros da superfície vestibular do esmalte periférico das margens cavitárias foram condicionadas com ácido e uma camada de selante Nuva-seal ou Concise foi aplicado em todas as paredes cavitárias internas; no grupo 5 os selantes e materiais foram aplicados como o método do grupo 4 e então $2 \mathrm{~mm}$ da superfície vestibular do esmalte foram condicionados novamente, e os selantes Nuva-seal ou Concise foram aplicados sobre a restauração. Depois os dentes foram preparados e imersos em solução de iodo (131) e $\mathrm{Na}$ por 24 horas. Passado este período, os espécimes foram lavados e seccionados longitudinalmente ao meio e montados sobre um filme de raio $\mathrm{X}$ por 36 horas. Em seguida, os filmes foram examinados seguindo o critério de escores de Hirsch e Weinreb's de 0 a 3 . Analisando os resultados obtidos os autores concluíram que se o selante é usado no interior da cavidade antes da colocação da restaurações e depois do polimento sobre as mesmas, a microinfiltração é eliminada. 
JÖRGENSEN; MATONO; SHIMOKOBE ${ }^{102}$, em 1976, estudaram a deformação de alguns tipos de cavidades com cargas axiais em dentes humanos, e o possível efeito desta deformação na qualidade da restauração destas cavidades. Dentes recém extraídos sem nenhum defeito visível na estrutura foram utilizados. Preparos pequenos de classe III e cavidades grandes de classe III foram preparados em incisivos superiores, enquanto cavidades MO, MOD e classe $\mathrm{V}$ foram realizados em pré-molares superiores. Para a segunda parte de estudo várias cavidades, condicionadas ou não condicionadas, foram restauradas com resina composta. Montados em um microscópio, os dentes sofreram carregamentos simulando a mordida ou mastigação. Cavidades restauradas eram aceitas somente quando nenhum microespaço marginal fosse encontrado. Os resultados mostraram uma deformação de cavidades vazias proporcional às que sofreram carregamento com $16 \mathrm{Kg}$, o aumento ou decréscimo em diâmetro variou de $0,1-1,0 \mu \mathrm{m} / \mathrm{Kg}$, dependendo do tipo de cavidade. A simulação da mastigação em dentes com cavidades restauradas, resultaram em "gaps" permanentes ou transitórios. A instabilidade dimensional das cavidades em dentes que sofreram carregamentos, indicam um severo risco de percolação para várias restaurações e fratura marginal de restaurações frágeis.

Em 1977, MORLEY; STOCKWELL ${ }^{133}$, enfatizaram a necessidade de simular as condições reais da cavidade oral, particularmente às mudanças de temperatura que ocorrem como resultado da ingestão de líquidos e alimentos quentes e frios, na avaliação do comportamento de materiais restauradores. Descreveram um aparelho simples designado à realizar estas mudanças automaticamente. $O$ instrumento descrito promove um método acelerado de testar os efeitos da ciclagem térmica e um meio de comparar a capacidade adesiva dos materiais. $\mathrm{O}$ aparelho consiste de 2 simples containers e dois banhos de temperaturas controladas de $60^{\circ} \mathrm{C}$ e $4^{\circ} \mathrm{C}$. Este aparelho necessita somente de água e eletricidade, e trabalha completamente automática ao longo do período de teste. 
O estudo de LLOYD; McGINLEY; BROWN ${ }^{113}$, em 1978, teve como objetivo medir a influência de mudanças térmicas na formação de trincas e fraturas nos dentes. Os fatores considerados neste estudo foram: a- variação do tipo e geometria dos dentes (molar, pré-molar, etc.), b- idade dos dentes, cpropriedades materiais dos dentes, $d$ - magnitude da mudança na temperatura do ambiente que envolve os dentes; e e- a resistência térmica entre o dente e o ambiente que envolve o dente. Os dentes foram submetidos a um estresse térmico e a presença de trincas e rachaduras no esmalte foram detectadas por análise dos dentes submetidos a um corante de penetração fluorescente. Foi possível concluir que a ingestão de bebidas extremamente geladas causa um estresse térmico excessivo que eventualmente pode levar ao aparecimento de trincas, que nem sempre levam a um efeito deletério, mas com certeza enfraquecem a estrutura dentária.

Em 1978, KIDD; HARRINGTON; GRIEVE ${ }^{105}$, avaliaram a capacidade de selamento de restaurações de resina composta utilizando uma técnica artificial de desenvolvimento de cárie, com a difusão controlada de um gel acidificado. Utilizaram 40 pré-molares extraídos, nos quais confeccionaram preparos cavitários de classe $\mathrm{V}$ e os restauraram com a resina composta Concise (3M). Os dentes foram então divididos em dois grupos. Os espécimes do grupo 1 foram ciclados entre banhos de água de $60^{\circ} \mathrm{C}$ e $4^{\circ} \mathrm{C}$, permanecendo por 1 minuto em cada banho, num total de 200 ciclos. No grupo 2, um banho adicional e intermediário foi acrescentado de $37^{\circ} \mathrm{C}$ e a ciclagem foi de $60^{\circ} \mathrm{C}$; $37^{\circ} \mathrm{C}, 4^{\circ} \mathrm{C}$ e $37^{\circ} \mathrm{C}$, também com 200 ciclos e permanecendo 1 minuto em cada banho. Terminada a ciclagem os espécimes foram estocados por 10 semanas em um gel ácido e em seguida seccionados, examinados em um microscópio de luz polarizada e a profundidade das lesões medidas por um micrômetro calibrado. O exame dos espécimes do grupo controle mostrou pequena evidência de infiltração marginal. Comparados com o grupo controle, os espécimes do grupo 2 mostraram uma redução ou nenhuma mudança no padrão de infiltração. O que sugere que a percolação térmica pode não ser de significância clínica em relação as restaurações com compósitos. 


\section{Em 1979, GLYN JONES; GRIEVE; HARRINGTON ${ }^{78}$,} apresentaram um novo modelo de máquina para ciclagem térmica que consistia de um mecanismo mais seguro e preciso do que o modelo apresentado por KIDD, em 1978. Esta máquina também apresenta quatro banhos na seguinte ordem: $37^{\circ} \mathrm{C}$ por 4 minutos, a baixa temperatura por 1 minuto; $37^{\circ} \mathrm{C}$ por 4 minuto e a alta temperatura por 1 minuto. O número de ciclos é controlado mecanicamente e a máquina é movido a eletricidade. Utilizaram esta máquina para pesquisar a infiltração marginal de alguns materiais: - Concise, Cosmic, e ASPA. Em 100 pré-molares extraídos confeccionaram cavidades de classe $\mathrm{V}$ com o ângulo cavo-superficial em $90^{\circ}$. 20 dentes foram restaurados com Concise e outros 20 com o mesmo material depois de condicionar as paredes com ácido fosfórico . O material Cosmic foi utilizado para restaurar 20 dentes e um outro grupo de 20 dentes foi restaurado com o mesmo material depois de ter sido aplicado o líquido Cosmic Bond. Todos estes espécimes foram estocados em água destilada a $37^{\circ} \mathrm{C}$ por 24 horas. Um outro grupo de 20 dentes foi restaurado com o cimento de ionômero de vidro ASPA. As cavidades foram condicionadas com ácido cítrico à $50 \%$ por 30 segundos. Estes espécimes foram armazenados da mesma maneira dos outros grupos. Depois disto os dentes foram preparados para a ciclagem térmica, e 10 dos 20 dentes de cada grupo foram termociclados. As temperaturas foram as seguintes: $37^{\circ} \mathrm{C}$ por 4 minutos; $15^{\circ} \mathrm{C}$ por 1 minuto; $37^{\circ} \mathrm{C}$ por 4 minutos e $45^{\circ} \mathrm{C}$ por 1 minuto, por aproximadamente 150 ciclos. Terminados os ciclos, os espécimes foram imersos em solução de fluorocromo a $0,1 \%$ por 72 horas à $37^{\circ} \mathrm{C}$. Os espécimes foram então seccionados e analisados em um microscópio por meio de uma escala de escores previamente estabelecida de 1 a 4 . Os autores ao analisarem o desempenho da nova máquina de ciclagem, consideraram-na muito boa, conseguiu manter as temperaturas constantes e contornou os efeitos da evaporação da água. Com relação aos materiais testados, os autores concluíram que o adesivo utilizado com a resina Cosmic, não reduziu a infiltração marginal. $E$ a ciclagem térmica não afetou a infiltração marginal ao redor das resinas compostas, sugeriram que a variação de temperatura não tem significância clínica nestes materiais restauradores. 
ORTIZ; PHILLIPS; SWARTZ; OSBORNE ${ }^{144}$, em 1979, investigaram "in vitro" a eficácia dos agentes de pré-tratamento (agentes de união) com relação ao selamento marginal das restauração das resinas compostas sobre superfícies de esmalte condicionadas e não condicionadas. Utilizaram três resinas compostas: - Simulate, Adaptic e Concise e seus respectivos agentes de união e soluções condicionadoras. Preparos cavitários classe $\mathrm{V}$ foram realizadas no terço médio de dentes caninos humanos extraídos. Um mínimo de 15 dentes foram restaurados com cada uma das resinas compostas e divididos em quatro grupos, com procedimentos diferentes para cada um: 1) resina composta; 2) agente de união + resina composta; 3) esmalte condicionado + resina composta; 4) esmalte condicionado + agente de união + resina composta. Depois de restaurados, os dentes eram imersos em água e armazenados em $37^{\circ} \mathrm{C}$ por duas semanas; durante a segunda semana de armazenamento 10 dos dentes de cada grupo de teste eram submetidos a 2500 ciclos de temperatura em dois banhos de água com diferença de $40^{\circ} \mathrm{C}$ entre elas. No final do período de duas semanas, o selamento marginal das restaurações foi testado através da imersão dos dentes numa solução aquosa de $\mathrm{CaCl}_{2}$ em uma concentração de $100 \mu \mathrm{Ci} / \mathrm{ml}$ com $\mathrm{pH}$ 5,5. Removidos do isótopo, os dentes foram seccionados longitudinalmente e colocados num filme de RX para a produção de auto-radiografias. Como era de se prever, a ciclagem térmica provou ser um teste mais potente do que o armazenamento em $37^{\circ} \mathrm{C}$. Com poucas exceções, a resistência de união resina-esmalte foi mais baixa entre os espécimes termociclados do que entre aqueles armazenados em uma temperatura constante. Os resultados deste estudo indicam que o condicionamento ácido do esmalte antes da inserção da resina composta geralmente diminui a microinfiltração e também aumenta a resistência de união da resina ao esmalte. Por outro lado, o uso de um agente de união sobre o esmalte não condicionado tem pouco efeito sobre a microinfiltração. Para o Adaptic e Concise, o agente de união aplicado ao esmalte condicionado não aumentou significantemente a resistência de união resina-esmalte, além do conseguido pelo condicionamento apenas. 
Em 1980, HARPER et al. ${ }^{93}$, provocaram estímulos térmicos na superfície de restaurações "in vivo", e mediram as mudanças de temperatura na parede pulpar de restaurações de amálgama sem base e com base de duas espessuras diferentes, assim como embaixo de restaurações de resina composta e silicato. Confeccionaram cavidades de Classe $\mathrm{V}$ em incisivos centrais superiores não cariados e que seriam extraídos por problemas periodontais. Pares termoelétricos foram colocados em contato com a parede pulpar e as restaurações realizadas. Os estímulos térmicos foram em dois extremos $0^{\circ} \mathrm{C}$ e $54^{\circ} \mathrm{C}$ por um período de 10 segundos, enquanto isto, a temperatura era monitorada por um galvanômetro. A difusão térmica foi muito alta através do amálgama e bem mais lenta através das restaurações de resina. A proporção de difusão através das resinas compostas e cimento de silicato permaneceu entre os extremos. As bases de cimento de fosfato de zinco e óxido de zinco e eugenol reduziram a proporção de mudanças térmicas no assoalho das cavidades restauradas com amálgama. A mudança de temperatura foi geralmente menor embaixo de uma base de $1 \mathrm{~mm}$ do que de uma base de $0,5 \mathrm{~mm}$. Bases usadas embaixo de restaurações não metálicas, não reduziram a magnitude das mudanças térmicas no assoalho cavitário.

Em 1981, CRIM; MATTINGLY49 ${ }^{49}$, se propuseram a investigar a diferença entre dois métodos "in vitro" de promover infiltração marginal. 40 cavidades de classe $V$ foram confeccionadas nas faces $V$ e $L$ de pré-molares humanos e restaurados com resina composta (Concise -3M). 20 dentes restaurados foram submetidos a ciclagem térmica em banhos de fucsina básica a $0,5 \%$, por 1500 ciclos. Um ciclo consistiu de 4 segundos em $60^{\circ} \mathrm{C}, 23$ segundos em $37^{\circ} \mathrm{C}, 4$ segundos em $5^{\circ} \mathrm{C}$ e 23 segundos em $37^{\circ} \mathrm{C}$. Os outros 20 dentes permaneceram por 25 horas em uma solução igual de fucsina. Depois deste passo, os dentes foram seccionados e avaliados em um microscópio com 20 vezes de aumento, seguindo escores de 0 e 4 . Neste estudo, demonstraram uma significante diferença na microinfiltração do grupo que sofreu ciclagem térmica para o que não foi ciclado. 
DOUGLAS; ZAKARIASEN ${ }^{59}$, em 1981, avaliaram a infiltração apical de raízes, de acordo com um método "in vitro" por espectrofotometro, que determina o volume do corante infiltrado. Neste método, os dentes testados são obturados com cera exceto o foramen apical e submergidos em uma solução de azul de metileno a $2 \%$. Depois remove-se a cera e o dente é dissolvido em ácido nítrico. Utilizando-se uma relação linear que existe entre a concentração de corante e a leitura do espectrofotômetro, a concentração da solução testada é determinada. Com isto o volume de corante que penetrou no interior do canal é calculado. Dentro deste teste existe a possibilidade da estrutura da raiz absorver o corante por outro local que não seja o ápice, e neste caso, o volume de infiltração calculado pode ser incorreto. Os autores afirmam que este tipo de teste tem sido bastante utilizado em vários estudos de microinfiltração, classificando-se como um método fácil de ser utilizado, sujeito a mínimo erro humano, e permite determinar o volume da infiltração, em vez de medir linearmente.

SILVA FILHO; SIMÕES ${ }^{180}$, em 1981, estudaram comparativamente a infiltração marginal na interface dente/restauração, com três resinas restauradoras: convencional (Texton), composta (Adaptic) e aerosil (Isopast). Outras variáveis foram consideradas como, a expansão higroscópica devido à sorpção de água e ciclagem térmica. As cavidades foram preparadas em dentes extraídos e livres de cáries. Depois de restauradas as cavidades seguindo instruções dos fabricantes, foram submetidos à seguinte seqüência de ciclagem térmica : 1) 60 minutos à $37^{\circ} \mathrm{C}$; 2) 15 segundos à $10^{\circ} \mathrm{C}$ por 15 segundos em cada temperatura por 10 ciclos; 3) novamente 60 minutos à $37^{\circ} \mathrm{C}$; 4) 10 ciclos de 15 segundos à $50^{\circ} \mathrm{C}$ e $37^{\circ} \mathrm{C}$; 5) 6 horas em $37^{\circ} \mathrm{C}$; 6 repetiu-se os itens 2 e 3.Todos os ciclos foram realizados em solução de Rodamina $B$ à $0,2 \%$. A infiltração marginal foi avaliada pelo critério de Bassiouny, que classifica de 0 a 10 os graus de infiltração, baseado na penetração do corante na interface dente/restauração. Concluíram que todos os materiais utilizados sofreram infiltração nas margens, em vários graus e que a resina convencional foi a que sofreu maior infiltração e a aerosil, a menor. A 
sorpção de água reduziu a infiltração marginal, enquanto a ciclagem térmica aumentou-a.

NAKABAYASHI; KOJIMA; MASUHARA ${ }^{138}$, em 1982, sugeriram que uma engrenagem mecânica formada pela penetração de prolongamentos de resina, "tags", dentro dos túbulos dentinários poderia resultar em uma adesão diferente pela falta de união entre estes e as paredes dos túbulos. Afirmaram ser necessário aproveitar as características hidrofílicas e hidrofóbicas de monômeros que contenham metacrilatos (Phenyl-P, 4-Meta, Co-polímero MMA/TTB) com a capacidade de infiltrar a rede de fibras colágenas expostas na dentina intra e intertubular para promover e aumentar a força de união. Por isso, estudaram a efetividade do monômero 4-Meta em MMA/TBB na adesão de um ciclindro de acrílico ao esmalte e dentina bovina e humana condicionadas com uma mistura aquosa de ácido cítrico e cloreto férrico. Após a ciclagem térmica, foram realizados testes de resistência à tração e uma análise com o microscópio eletrônico de varredura. Descobriram que o monômero infiltrava nas fibras colágenas expostas e polimerizava-se no local, formando uma zona mista, ácido resistênte, da resina permeada pelo monômero. Foi denominada camada híbrida e considerada determinante na união da resina composta à dentina aumentando a resistência de união. Descreveram portanto, uma adesão micromecânica que ocorre pela infiltração do monômero da resina na superfície dentária, e quando esse monômero se polimeriza, produz uma dentina reforçada por resina que é composta por colágeno da dentina e hidroxiapatita que está infiltrada e circundada pelo polímero.

Devido à diferença de coeficiente de expansão das resinas convencionais e de micropartículas, RETIEF; RUTLAND; JAMILSON ${ }^{165}$, em 1982, avaliaram "in vitro" a microinfiltração de dois sistemas de resina. Preparos cavitários de classe $\mathrm{V}$, com margem cavo-superficial em ângulo reto no meio da face vestibular da coroa de 80 pré-molares humanos, não cariados; foram confeccionados. Os preparos foram condicionados com ácido fosfórico. 40 preparos foram restaurados com Concise e 40 com resina de micropartícula 
Silar. 10 dentes de cada grupo foram submetidos a mudanças ciclícas de temperatura entre 5 e $55^{\circ} \mathrm{C}$ por $1.000,2.500$ ou 5.000 ciclos, respectivamente, e 10 dentes de cada grupo não foram ciclados (controle). Depois da restauração, os dentes foram imersos em solução de $\mathrm{Ca}^{45}$ por 18 horas. $\mathrm{A}$ microinfiltração foi avaliada através de escores de 0 a 3, nas margens cervical e oclusal das restaurações. Os autores concluíram que a microinfiltração nas restaurações de resina composta classe $\mathrm{V}$ foi significativamente maior nas margens cervical do que nas margens oclusal.

Em 1982, HANSEN ${ }^{90}$, investigou a contração de polimerização, o padrão de contração e a expansão higroscópica de 4 resinas fotopolimerizáveis (Durafill, Heliosit, Silux, Visio Dispers) e uma química (Silar), quando usadas em cavidades não condicionadas e sem bisel no esmalte. Cavidades cilindrícas com aproximadamente $2,5 \mathrm{~mm}$ de diâmetro e $1,5 \mathrm{~mm}$ de profundidade foram confeccionadas na raiz de dentes extraídos, as cavidades depois de prontas foram lavadas com Tubulicid e os autores não utilizaram nenhum material de proteção na parede axial. Depois disto, as cavidades foram restauradas. Os "gaps" marginais foram medidos por meio de uma Camera Microscópica Universal Reichert $\mathrm{M}$ e F, com uma ocular com possibilidade de observar

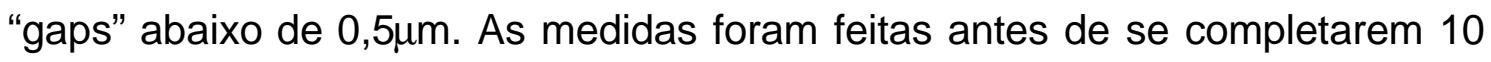
minutos depois da polimerização inicial, e as restaurações foram divididas em 5 grupos diferentes de acordo com o modo de leitura: grupo 1: os dentes foram desgastados e polidos imediatamente após a polimerização inicial e a profundidade de registro foi de $100 \mu \mathrm{m}$ Realizaram de 16 a 24 medidas em locais diferentes das margens e o microespaço para cada quadrante foi calculado; grupo 2: os dentes foram colocados em solução de $\mathrm{NaCl}$ a $0,9 \%$ por 1 minuto, depois da polimerização inicial. A superfície das restaurações não foram mais tocadas e depois de 7 dias \pm 30 minutos de absorção de água, 0 microespaço marginal foi medido como no grupo 1; grupo 3- as medidas dos microespaços foram feitas depois de 28 dias \pm 1 hora de absorção de água e a profundidade de registro foi de $100 \mu \mathrm{m}$; grupo 4: as restaurações foram desgastadas e polidas imediatamente após a polimerização inicial com o registro do microespaço em $100 \mu \mathrm{m}$, em seguida a restauração foi desgastada e 
polida em várias profundidades e os microespaços medidos em cada uma delas (200, 300, 500, 800 e 1.200 $\mu \mathrm{m}$ ); grupo 5: o padrão de contração da resina química foi registrada como no grupo 4. Concluíram que todas as resinas mostraram uma pronunciada contração de polimerização, sendo que o Visio-Dispers contraiu quase 3 vezes mais que o Heliosit. Heliosit e Silux não apresentaram diferenças significantes entre si.

RETIEF; WOODS; JAMISON ${ }^{166}$, em 1982, avaliaram "in vitro" o efeito das técnicas restauradoras incluindo alguns fatores que possivelmente influênciam a infiltração marginal em restaurações de resina composta, como por exemplo: o formato do ângulo cavo-superficial, condicionamento ácido, e utilização de resinas de baixa viscosidade. Para tanto, cavidades de Classe V foram confeccionadas em 60 caninos superiores humanos, que foram limpos e armazenados em etanol a $70 \%$. Os materiais utilizados foram a resina composta Adaptic e o agente de união Adaptic de baixa viscosidade. Os preparos no sentido mésio-distal mediam aproximadamente $4 \mathrm{~mm}$ e com largura de $2 \mathrm{~mm}$. A margem gengival foi localizada em esmalte a $2 \mathrm{~mm}$ da junção cemento/esmalte e com $2 \mathrm{~mm}$ de profundidade. 30 espécimes permaneceram com o ângulo cavo-superficial em $90^{\circ} \mathrm{C}$ e os outros 30 , tiveram o mesmo ângulo biselado em $45^{\circ} \mathrm{C}$. Depois de terminados os preparos e restaurados, os dentes foram preparados e levados a ciclagem térmica em banhos de vermelho fluorescente; a ciclagem contou com 100 ciclos que foram realizados manualmente em temperaturas de $5^{\circ} \mathrm{C}$ e $55^{\circ} \mathrm{C}$, permanecendo 1 minuto em cada temperatura. Após a ciclagem, os dentes foram estocados em solução corante a $37^{\circ} \mathrm{C}$ por uma semana. Passado este período, os espécimes foram seccionados em vários cortes no sentido longitudinal vestíbulolingualmente. As secções foram examinadas em microscópio e fotografadas com filme Ektachrome. Os slides foram projetados e avaliados por escores préestabelecidos de 0 a 3 . Analisando os resultados obtidos, os autores concluíram que: o condicionamento das paredes do esmalte em preparos com ângulo cavo-superficial biselado reduziu significativamente a infiltração marginal na margem incisal; a aplicação de uma resina adesiva de baixa viscosidade às paredes condicionadas do esmalte dos preparos antes da 
inserção da resina composta não foi necessária para obter uma mínima infiltração na interface resina composta/esmalte; a configuração do cavosuperficial e as técnicas restauradoras usadas neste estudo afetaram o grau de micro-infiltração até certo grau, mas não a eliminaram.

BOWEN; RAPSON; DICKSON ${ }^{18}$, em 1982, consideraram a contração de polimerização das resinas compostas como uma das causas das falhas marginais das restaurações, por dificultar a obtenção de uma adequada adesividade. Avaliaram além dessa propriedade, a expansão higroscópica das resinas compostas. Para verificar se a expansão dos materiais era suficiente para compensar a contração de polimerização inicial testaram quatro resinas comerciais: Adaptic, Cervident, Concise e Nuva-Fil; uma resina acrílica: Servitron; e três resinas experimentais com $75 \%$ de carga inorgânica. A diferença entre os materiais testados era o monômero diluente (TEGMA, HEMA e Silano). Realizados os testes, obtiveram como resultado que todos estes materiais contraem durante a polimerização e expandem quando submersos em água. No entanto, apenas os espécimes de resina acrílica e de uma das resinas compostas experimentais, que possuíam o monômero HEMA, expandiram o suficiente para compensar a contração inicial. Os autores concluíram que a expansão higroscópica pode contribuir para aliviar as tensões acumuladas durante a contração de polimerização, sendo portanto, possível formular resinas compostas que permitam uma expansão higroscópica suficientemente alta para compensar a contração inicial sofrida pelo material.

Em 1982, SHORTALL ${ }^{178}$, publicou um artigo de revisão de métodos desenvolvidos para medir microinfiltração. Comentou que muitas investigações de microinfiltração "in vitro" parecem ter duvidosa relevância clínica assim como, pequenas diferenças na microinfiltração demonstrada entre diferentes técnicas restauradoras e materiais. Muitas das diferenças nos resultados entre os estudos podem ser parcial ou totalmente devido a variações nas técnicas experimentais, e aconselhou uma padronização dos testes de microinfiltração para que se pudesse comparar resultados de diferentes estudos. Julgou os testes de microinfiltração importantes para se 
testar "in vitro" novos materiais restauradores. Descreveu o ambiente oral como tendo um profundo significado no sucesso e longevidade de algumas restaurações e que portanto, o ideal seria aguardarmos os resultados de testes clínicos longitudinais de técnicas e materiais restauradores para obtermos um melhor entendimento da significância clínica dos achados das investigações "in vitro".

Em 1984, CHALKLEY; JENSEN ${ }^{37}$, estudaram os efeitos de alguns fatores no padrão de microinfiltração de uma resina composta de micropartícula ativada pela luz. As variáveis incluídas foram: diferentes preparos do ângulo cavo-superficial (reto e biselado), agente adesivo (Scotchbond e Enamel bond), tempo de polimento (imediato, depois de 5 minutos e de 20 minutos) e localização (oclusal e gengival). 120 cavidades padronizadas de $2,5 \mathrm{~mm}$ de diâmetro foram confeccionadas em terceiros molares e pré-molares extraídos. Metade das amostras receberam um bisel de $0,5 \mathrm{~mm}$ e a margem de todos os preparos ficou localizada em esmalte; o esmalte sempre foi condicionado e a resina utilizada foi a Silux. Depois de sofrerem os polimentos conforme os tempos determinados, os dentes foram estocados em água por uma semana e termociclados por 540 ciclos em banhos de $5^{\circ} \mathrm{C}$ e $55^{\circ} \mathrm{C}$. Para detectar a infiltração marginal foi utilizada a prata. Com base na análise estatística concluíram que: 1- a microinfiltração foi não influenciada pelo tempo esperado para o polimento; 2- o biselamento do ângulo cavo-superficial produziu significantemente menor infiltração do que em ângulo reto; 3- o Scotchbond reduziu a infiltração marginal; 4- um pior selamento marginal esteve presente na margem cervical que na oclusal, mesmo com todas as margens em esmalte.

WILLIAMS; SVARE ${ }^{203}$, em 1984, se preocuparam com um dos problemas dos testes "in vitro" para testar força adesiva entre esmalte e resina composta, que segundo os autores é o possível efeito da duração da estocagem dos dentes antes da adesão. Relataram ser comum estes estudos descreverem que utilizam "dentes recém extraídos", ou "dentes extraídos" mas sem especificar quando. Neste estudo, portanto, avaliaram o efeito de dentes 
estocados por cinco anos antes da adesão (24 dentes) e por 3 meses ou menos. Decorridos os tempos necessários, botões de resina com 2,3 mm de diâmentro foram aderidos ao esmalte usando condicionamento ácido e sistema fotopolimerizável. As amostras foram testadas na máquina de teste Instron, com velocidade de $0,5 \mathrm{~cm} / \mathrm{min}$. E célula de carga de $500 \mathrm{Kg}$. Os resultados mostraram que não foi significante a diferença da força adesiva entre os dentes estocados por 5 anos e os por 3 meses; a superfície lingual pareceu desenvolver uma maior adesão, e que ocorreram 54\% de fratura no esmalte. Concluíram que o tempo de estocagem antes do teste adesivo não afetou a união entre a resina e o esmalte.

BAUER; HENSON ${ }^{10}$, em 1984, revisaram aspectos da microinfiltração e o papel desta na avaliação da integridade da adaptação marginal de materiais restauradores. A ocorrência da microinfiltração tem sido amplamente utilizada para avaliar o sucesso de um procedimento e/ou material restaurador. Existem fatores que favorecem à infiltração marginal, afetando conseqüentemente, o desempenho clínico da restauração, e são: a presença de fendas interfaciais, propriedades físicas inadequadas do material (solubilidade, porosidade, contração e expansão térmica) e procedimentos restauradores incorretos. Clinicamente, os efeitos da microinfiltração manifestam-se por meio da hipersensibilidade dentinária, cárie secundária, descoloração marginal, entre outros. Diferentes técnicas laboratoriais têm sido utilizadas para medir a extensão da microinfiltração. Entre as mais empregadas estão o método de ar pressurizado, que demonstra a presença de bolhas na margem cavo-superficial, a penetração de corantes, isótopos radioativos e a presença de bactérias ou cáries. A maioria dos métodos mencionados utilizam a ciclagem térmica, expondo as restaurações a situações clínicas simuladas que normalmente criam estresse no selamento marginal, o que é importante quando o coeficiente de expansão térmica do material restaurador difere daquele da estrutura dentária.

Em 1984, PASHLEY ${ }^{147}$, publicou um trabalho apresentando várias considerações fisiológicas sobre a "smear layer". Definiu-a como uma 
camada de pequenas partículas de matriz orgânica fragmentada pela ação de instrumentos cortantes manuais ou ratatórios sobre os tecidos dentários durante a confecção do preparo cavitário. Apesar desse fenômeno também ocorrer em esmalte, é mais significativo em dentina. Afirmou que a espessura da "smear layer" era de aproximadamente 1 a $5 \mu \mathrm{m}$, mas variavél de acordo com o modo da dentina ser cortada, do tamanho e forma da cavidade, do tipo de instrumento empregado e do uso ou não de jatos de água. $O$ autor citou estudos que mostraram que a "smear layer" é importante porque diminui a permeabilidade dentinária, porém, a sua presença pode interferir na união de materiais capazes de se unirem quimicamente com a dentina. Existem ácidos fortes que removem a "smear layer" completamente, abrindo os túbulos dentinários, mas o condicionamento ácido da dentina aumenta o movimento de fluídos dentro do tecido, provocando sensibilidade dentinária. Portanto,existem dois pontos de vista que, segundo o autor, estão corretos e que deverão ser considerados para desenvolver 0 pré-tratamento do substrato e o material restaurador mais adequado. O primeiro explica que a "smear layer" é benéfica, pois produz uma cobertura natural das paredes cavitárias, com efetividade maior do que alguns vernizes. O segundo é que esta camada interfere na adaptação e adesão dos materiais com a dentina, podendo abrigar microorganismos e suas toxinas, os quais são agressivos ao tecido pulpar.

WELSH; HEMBREE ${ }^{201}$, em 1985 avaliaram a infiltração marginal de quatro materiais disponíveis para restaurações colocados em regiões de abrasão/erosão cervical simulada (Concise; Fuji ionomer cement; Den-Mat dentin bonding system e Clearfil). O Concise foi usado como controle positivo e o cimento de ionômero de vidro como controle negativo por se unir à superfície cemento/dentina. Setenta e dois pré-molares foram utilizados, uma área de abrasão/erosão foi mecanicamente produzida em cada dente com um disco de carborundum. A margem oclusal/incisal foi localizada em esmalte e a margem gengival em superfície de cemento/dentina. Depois das restaurações realizadas, os espécimes foram termociclados em água nas temperaturas de $4^{\circ} \mathrm{C}$ e $58^{\circ} \mathrm{C}$ por 100 ciclos, permanecendo 1 minuto em cada banho. Cada grupo foi testado em 1 semana, 3 meses e 6 meses, o que proporcionou 6 
espécimes de cada material em cada intervalo de tempo. Os espécimes foram, então, imersos por 2 horas em solução de isótopo de $\mathrm{Ca}^{45}$. A concentração do isótopo foi $0,1 \mathrm{~m} \mathrm{Ci} / \mathrm{ml}$ de solução na forma de cloreto de cálcio com pH 7 . Depois de removidos do isótopo e lavados com detergente foram embebidos em resina e seccionados longitudinalmente através da restauração, e colocados por 17 horas em um filme radiográfico para a produção de autoradiografias. Os filmes foram então classificados segundo escores de 0 a 4 para demonstrar o grau de infiltração. Houve mais infiltração nas margens gengivais em dentina e cemento do que nas margens incisais no esmalte. Os resultados deste trabalho indicam que apesar das alegações dos fabricantes, que as resinas utilizadas se unem perfeitamente ao cemento e dentina, e que não apresentam infiltração, isto ainda não foi conseguido; e o cimento de ionômero de vidro não apresentou infiltração significativa em qualquer período de tempo dos testes de avaliação.

Para comparar quatro métodos de termociclagem, CRIM; SWARTZ; PHILLIPS ${ }^{50}$, em 1985, utilizaram dois traçadores:- fucsina básica $0,5 \%$ e Ca. ${ }^{45}$ Além de diferentes traçadores, lançaram mão de dois sistemas de termociclagem: $1^{\circ}$ sistema: $4 \mathrm{~s}$. em $60^{\circ} \mathrm{C} ; 23 \mathrm{~s}$ em $37^{\circ} \mathrm{C}$; $4 \mathrm{~s}$ em $12^{\circ} \mathrm{C} ; 23 \mathrm{~s} \mathrm{em}$ $37^{\circ} \mathrm{C}$, por 1.500 ciclos; $2^{\circ}$ sistema: $60^{\circ} \mathrm{C}$ e $12^{\circ} \mathrm{C}$, $30 \mathrm{~s}$ em cada banho, por 1.500 ciclos. Confeccionaram preparos de Classe $\mathrm{V}$ nas cervicais vestibulares e linguais de 15 pré-molares e restauraram com a resina composta Concise. Antes da ciclagem térmica, os dentes foram selados com esmalte e papel prateado, deixando somente a restauração exposta, em seguida foram colocados em água a $37^{\circ} \mathrm{C}$ por 1 hora. Depois foram separados em grupos de 10 cavidades para serem submetidos aos métodos seguintes: Método $1 \mathrm{~A}$ : usou o primeiro sistema de ciclagem com uma solução aquosa de fucsina básica a 0,5\%; em cada um dos 4 banhos; Método 1B: usou o primeiro sistema de ciclagem com água livre de corante nos banhos, foram colocados em fucsina básica a 0,5\% depois da ciclagem em temperatura ambiente por 24 horas; Método 2A: usou o segundo sistema de ciclagem com banhos de água, depois da ciclagem foram colocados em solução corante por 24 horas; Método 2B: usou o segundo sistema de ciclagem com banhos em água, depois foram 
colocados em solução aquosa de $\mathrm{Ca}{ }^{45}$ em temperatura ambiente com concentração radiotiva de $0,1 \mathrm{mCi} / \mathrm{ml}$ e $\mathrm{pH}$ de 5,5 por 2 horas, em seguida foram expostos por 17 horas em filme radiográfico dental Kodak ultra-speed para produzir autoradiografias para avaliação da infiltração. Método 3: considerado grupo controle, não foram ciclados, mas foram imersos em corante por 24 horas. Terminados os tratamentos os espécimes foram analisados seguindo critérios de escores de 0 a 3 . Concluíram não haver diferenças significantes entre as quatro técnicas de termociclagem, assim como para os dois traçadores testados. Porém, todos os procedimentos envolvendo mudanças térmicas foram mais potentes para demonstrar infiltração do que o método que não foi ciclado.

O efeito da ciclagem térmica e do carregamento oclusal na união entre resina composta e dentina tratada com sistema adesivo foi testada por MUNKSGAARD; JÖRGENSEN; ITOH ${ }^{136}$, em 1985. Em dentes humanos extraídos confeccionaram cavidades cilíndricas com aproximadamente metade das margens em dentina. Metade dos espécimes tiveram sua parede de fundo protegidas com uma fina camada de $\mathrm{Ca}(\mathrm{OH})_{2}$ (Dycal) e foram tratados com dois sistemas adesivos, Gluma e Clearfil Bond, antes de restaurar com resina Silux. 40 espécimes foram ciclados 100 vezes entre $15^{\circ} \mathrm{C}$ e $50^{\circ} \mathrm{C}$, por 14 segundos em cada banho, iniciada 20 minutos após a polimerização e 24 horas após. Depois foram inspecionados em microscopia e não foi observado alterações na união entre a margem cavitária e a restauração de resina composta. Dentes com cavidades de classe III e V, 10 de cada, com as margens gengivais inteiramente em dentina, foram pré-tratadas e restauradas como acima. Os dentes foram cobertos com um corante durante 0 carregamento e descarregamento de maneira a simular a mastigação com cargas de 2, 4, 8, 12 e $16 \mathrm{Kg}$. A inspeção das margens cavitárias revelou ausência de percolação nas margens de dentina. Concluíram a efetividade dos adesivos, e que estes são necessários para prevenir os "gaps" em restaurações de resina onde as margens estão localizadas totalmente ou parcialmente em dentina 
HEMBREE JR; TAYLOR ${ }^{97}$, em 1985 avaliaram, no laboratório, a infiltração marginal de restaurações de resina composta usando uma combinação de resina convencional e de micropartículas. A resina composta convencional utilizada foi a Estilux e a de micropartículas foi a Durafil. Prepararam 72 cavidades de classe V em dentes sadios, pré-molares e anteriores. Depois de limpos, os dentes foram divididos ao acaso em três grupos de 24 dentes cada. O primeiro grupo foi restaurado com resina composta convencional; o segundo, com resina de micropartículas, e o terceiro restaurado até aproximadamente $1 \mathrm{~mm}$ do ângulo cavo-superficial da cavidade com resina convencional e completado com resina de micropartículas. Antes dos testes, cada espécime foi termociclado alternadamente com spray de água por 1 minuto cada, à $4^{\circ} \mathrm{C}$ e $58^{\circ} \mathrm{C}$ por 100 ciclos. Cada grupo foi testado em intervalos de tempo de uma semana, 3 meses, 6 meses, e um ano. Para cada intervalo de tempo, 6 espécimes eram testados. A adaptação marginal foi determinada pela presença de isótopo na interface do dente com o material restaurador. Os espécimes eram imersos em solução de $\mathrm{Ca}^{45}$ por duas horas. Seis autoradiografias foram produzidas para cada material restaurador nos intervalos de tempo já citados. Os autores concluíram que a infiltração marginal foi eliminada ou grandemente reduzida com um ano utilizando resina composta convencional. Moderada ou grande infiltração foi demonstrada com uma resina composta de micropartículas. Quando associaram as duas, produziu uma mínima infiltração marginal. Clinicamente, segundo os autores, esta técnica controlou a infiltração marginal e produziu uma restauração com uma superfície lisa e estética. Os autores julgaram importante salientar que as resinas convencionais produzem menor infiltração marginal devido a seu coeficiente de expansão térmica linear ser mais próximo ao da estrutura dentária.

FUKS; HIRSCHFELD; GRAJOWER ${ }^{72}$, em 1985, investigaram por meio da penetração de corante o grau de infiltração marginal ao redor de restaurações cervicais em forma de V. Utilizaram 40 pré-molares extraídos e dividiram-nos em dois grupos. O grupo A, com 20 dentes foi preparado e restaurado com Silux, usando Scotchbond como sistema adesivo. O grupo B, depois de preparado foi restaurado com a mesma resina composta e um 
sistema adesivo convencional, somente na margem de esmalte oclusal. Depois de restauradas e polidas as restaurações, os espécimes foram armazenados por uma semana e então submetidos à ciclagem térmica. Ambos os grupos foram termociclados por 100 vezes entre $4^{ \pm} 2^{\circ} \mathrm{C}$ e $60{ }^{ \pm} 2^{\circ} \mathrm{C}$, permanecendo por 1 minuto em cada banho. Terminada a ciclagem, os dentes foram cobertos com esmalte para unha, exceto $5 \mathrm{~mm}$ ao redor das restaurações e imersos em fucsina básica a $2 \%$ por 24 horas. Os dentes foram então imersos em resina acrílica e seccionados em três secções no sentido vestíbulo-lingual. Cada secção foi fotografada por intermédio de um microscópio e a profundidade de penetração do corante avaliado por um critério de escores de 0 a 3 , para a margem oclusal e de 0 a III para a margem gengival. Os resultados deste estudo mostraram que a infiltração na margem gengival em dentina/cemento foi reduzida grandemente pelo Scotchbond quando testado uma semana depois das restaurações serem confeccionadas.

A microinfiltração de quatro resinas compostas (Herculite, PrismaFil, Silux e Visio-Fil) sobre uma base de cimento de ionômero de vidro (Ketacbond) em restaurações de Classe $V$ foi investigada por GORDON et al ${ }^{85}$, em 1985. Vinte molares humanos extraídos foram selecionados para este estudo. Depois do preparo cavitário, o cimento de ionômero de vidro foi aplicado na parede axial e gengival, entretanto a margem da parede gengival próxima ao ângulo cavo-superficial permaneceu sem o cimento de ionômero de vidro. $\mathrm{O}$ ácido fosfórico foi utilizado nas margens de esmalte e sobre o ionômero de vidro, e a seguir um adesivo de esmalte e dentina foi aplicado sobre todas as margens cavitárias (Sankin). Os espécimes foram então divididos em quatro grupos de acordo com o material restaurador utilizado. Terminadas as restaurações, a superfície dos dentes foram seladas com um esmalte para unha, exceto $2 \mathrm{~mm}$ ao redor das margens da restauração e os ápices dos dentes selados com amálgama. Os dentes foram então termociclados por 120 ciclos, e cada ciclo consistiu de 25 segundos em um banho intermediário de $37^{\circ} \mathrm{C}, 5$ segundos em $5^{\circ} \mathrm{C}, 25$ segundos em $37^{\circ} \mathrm{C}$, e 5 segundos em $55^{\circ} \mathrm{C}$. Depois da termociclagem, os dentes foram imersos em solução de nitrato de prata a $50 \%$ por duas horas e colocados em um revelador fotográfico sobre 
uma luz fluorescente por quatro horas. Os dentes foram então seccionados longitudinalmente no sentido vestíbulo-lingual, e examinados por meio de um microscópio com 25 vezes de aumento e classificados de acordo com escores pré-determinados de 0 a 4 . De acordo com os resultados obtidos, os autores concluíram que: 1- todos os materiais testados mostraram infiltração; 2- Silux + Ketac bond proporcionaram os menores graus de penetração do corante em ambas as margens do preparo; 3- nas margens da parede oclusal, a combinação dos materiais com Silux mostraram significantemente menor penetração de corante do que Visio Fil ou Herculite, e a Prisma Fil obteve significantemente menor penetração que a Visio Fil; 4- nas paredes gengivais, a combinação dos materiais com Silux mostrou significantemente menor penetração do corante do que o Prisma Fil ou Visio Fil; a Herculite também infiltrou significantemente menos que a Visio Fil; 5 - a penetração do corante foi significantemente maior nas paredes gengivais (cemento/dentina) do que na oclusal (esmalte).

EAKLE $^{61}$, em 1986, determinou o efeito da ciclagem térmica na força de fratura e na infiltração de dentes posteriores restaurados com resina composta e adesivo. Utilizou 40 pares de pré-molares superiores, onde foram preparadas cavidades MOD, com dimensões uniformes e restaurados com resina composta (Scotchbond/P-30). Os dentes foram divididos em 2 grupos, o grupo controle sem ciclagem térmica e o grupo teste ciclado entre $5{ }^{\circ} \mathrm{C}$ e $55^{\circ} \mathrm{C}$ por 480 ciclos, permanecendo $30 \mathrm{~s}$ em cada banho. Depois da ciclagem os dentes foram corados com solução de nitrato de prata, e então fraturados por uma carga oclusal na máquina universal de teste. Observou um decréscimo na força de fratura dos dentes ciclados quando comparados com o grupo controle, entretanto com relação a microinfiltração não encontrou diferenças, ela foi intensa em ambos os grupos. Sugeriu que neste teste "in vitro" as variações na temperatura podem reduzir a força de fratura ganha com o adesivo da resina composta e que a contração de polimerização pode produzir significante microinfiltração, independente da ciclagem térmica. 
Em 1986, STANINEC et al. ${ }^{185}$, avaliaram os efeitos das alterações da temperatura sobre a largura do espaço entre o material restaurador e a estrutura dentária em cavidades condicionadas. Assim como a relação das alterações térmicas com a infiltração marginal e fraturas do esmalte. Compararam uma resina composta convencional (Clearfil, Kuraray) que apresenta um coeficiente de expansão térmica relativamente baixo, com uma resina composta de micropartícula (Isopast, Vivadent), que possui um coeficiente de expansão térmica relativamente alto. Utilizaram 16 incisivos centrais humanos extraídos. Cavidades de classe $\mathrm{V}$ foram preparadas na face vestibular; a margem cervical foi localizada abaixo da junção amelo-dentinária e a incisal em esmalte e biselada em $45^{\circ} \mathrm{C}$. Depois de preparadas as cavidades, e restauradas, os dentes foram ciclados em banhos de $4^{\circ} \mathrm{C}$ e $60^{\circ} \mathrm{C}$ permanecendo 3 minutos em cada um, num total de 100 ciclos. Terminada a ciclagem, as faces vestibulares dos dentes foram replicadas por meio de moldagens em duas temperaturas diferentes, $4^{\circ} \mathrm{C}$ e $60^{\circ} \mathrm{C}$. Os dentes eram mantidos nessas temperaturas por 15 minutos antes de realizarem as impressões; e o material de moldagem também foi utilizado nestas mesmas temperaturas. As moldagens foram vazadas em resina epóxica. A seguir os dentes foram revestidos com uma camada de esmalte para unha, exceto a restauração e sua margem, permaneceram então imersos em temperatura ambiente em solução aquosa de metil violeta a 0,025\%, por uma noite. No dia seguinte eram lavados e seccionados vestíbulo-lingualmente, e a penetração do corante foi medida por meio de um estéreo-microscópio com 40 vezes de aumento. Os dentes eram novamente limpos com ultra-som e as secções moldadas para a obtenção de modelos das mesmas. Esses modelos foram revestidos com íons de ouro e examinados em microscópio eletrônico de varredura. Por meio dos resultados obtidos os autores concluíram que os efeitos da temperatura foram mais pronunciados em restaurações de resina com micropartículas, devido ao coeficiente de expansão térmica destas serem mais alto que das resinas compostas convencionais. O espaço nas paredes oclusal e cervical aumentaram no estado frio, indicando contração do material restaurador; enquanto o espaço na parede axial aumentou no estado quente, indicando a expansão do material e movimento na direção vestibular. A 
infiltração marginal correlacionou-se a grosso modo com a presença e tamanho dos espaços interfaciais. As fraturas de esmalte foram encontradas mais freqüentemente em resinas de micropartículas e pareceram estar relacionadas à maior contração durante a polimerização e mais alto coeficiente de expansão térmica.

Em 1986, ERICKSON; JENSEN ${ }^{65}$, compararam os efeitos de cargas ciclícas e o término marginal na microinfiltração ao redor de restaurações de compósitos. 3 grupos foram testados: 1) Classe $V$ com bisel; 2) Classe II MOD com bisel, e 3) Classe II MOD com ângulo reto. As margens terminaram em esmalte sadio e em superfície de raiz. As restaurações foram realizadas com o adesivo Scotchbond e resina P-30. Cada grupo foi dividido em espécimes de teste e controle. Os grupos testes foram montados em um material de metilmetacrilato, submersos em solução de $\mathrm{Ag} \mathrm{NO}_{3}$ a $50 \%$ e, 2000 cargas ciclícas foram aplicadas usando a máquina Universal Instron entre 0 e 9 $\mathrm{Kg}$ durante 2 horas. Então foram colocados no revelador por 10 minutos. Os dentes foram seccionados e avaliados. Nas restaurações de classe $V$ não encontraram diferenças estatísticas entre os grupos controle e ciclados quando as margens estavam em esmalte, já nas margens em raiz houve diferença estatística entre o controle $(1,3 \pm 6)$ e o ciclado $(2,4 \pm 1,2)$. No grupo das restaurações de classe II com margens retas não houve diferenças entre 0 grupo controle $(1,0 \pm 1,4)$ e ciclados $(1,0 \pm 1,2)$. Entretanto existiu diferença significante entre este e o grupo de classe II com margens biseladas (controle $0,3_{ \pm 0}, 8$ e ciclado $\left.0,5_{ \pm} 1,1\right)$. Indicando que bisel nas margens de preparo para classe II pode reduzir a microinfiltração.

Em 1986, SPIERINGS; VARST; PETERS ${ }^{183}$, tentaram obter uma descrição matemática da temperatura no ambiente do dente induzida pelo consumo de bebida quente, em função do tempo. Bebendo uma bebida aquecida a $60^{\circ} \mathrm{C}$, a temperatura ambiente do dente foi relatada por um par termoelétrico de cobre fixado no lado palatino dos dentes posteriores. Simultaneamente, a temperatura também foi relatada em um pôntico de resina assimétrico na região de pré-molar. A experiência foi repetida cuidadosamente 
cinco vezes com duas pessoas. O consumo desta bebida resultou em uma curva de temperatura com a média máxima da temperatura de $48,5 \pm 3,7^{\circ} \mathrm{C}$, decrescendo com o tempo. O experimento descreveu dados exatos sobre os primeiros 60 segundos depois da ingestão do líquido. Utilizando estes resultados, a distribuição da temperatura dentro do modelo matemático do pôntico foi calculado usando análise do elemento finito. Boa concordância foi encontrada entre a análise do elemento finito e o experimento "in vivo".

Em 1986, DERKSON; PASHLEY; DERKSON ${ }^{55}$, descreveram um novo método para medir microinfiltração "in vitro" ao redor de materiais restauradores e avaliaram por comparação a microinfiltração de restaurações de amálgama e resina. Este método quantifica a permeabilidade dentinária e a microinfiltração. $O$ dispositivo contêm gás nitrogênio a uma pressão de 5 a 12 psi, que é aplicado a um reservatório contendo um beker plástico de solução salina tamponado contendo fluresceina a $0,2 \%$. Uma pequena bolha de ar em uma micropipeta permite que o fluído se movimente e seja quantificado. Os autores utilizaram molares e executaram cavidades oclusais e restauraram com resina composta, amálgama associado ao verniz e amálgama somente. Depois de avaliarem os resultados concluíram que: 1- a medida da permeabilidade da dentina pode ser aplicada para medir a microinfiltração; 2- a medida pode ser feita longitudinalmente e quantitativamente; 3 - as restaurações de amálgama com verniz infiltraram menos do que as restaurações de amálgama sem verniz; 4- este estudo foi incapaz de determinar os fatores responsáveis pela grande falha, nas restaurações de resina composta; e 5- a ciclagem térmica não alterou significantemente a magnitude do padrão de microinfiltração do amálgama ou da resina composta.

A microinfiltração de restaurações de resina composta posteriores foi avaliada por FAYYAD; SHORTALL ${ }^{68}$, em 1987. Sua investigação "in vitro" avaliou a infiltração marginal de preparos classe II (MOD) extensos que haviam sido restaurados com resinas compostas posteriores fotopolimerizáveis, usando somente adesivos ou bases de cimento de ionômero de vidro. Dividiram 40 dentes extraídos em quatro grupos, onde foram utilizados 
diferentes materiais restauradores e de bases para cada um deles. Cada preparo apresentou uma das caixas proximais com o término cervical a $1 \pm 0,25 \mathrm{~mm}$ aquém da junção cemento-esmalte e a outra, $1 \pm 0,25 \mathrm{~mm}$ além dessa mesma junção. Quinze minutos após o término das restaurações, eram realizados os procedimentos de acabamento e polimento e os dentes eram colocados em água destilada por 1 semana à $37^{\circ} \mathrm{C}$ antes, da ciclagem térmica. A ciclagem térmica foi realizada em solução de $1 \%$ de azul de metileno, consistiu de 150 ciclos e as temperaturas eram as seguintes: $37^{\circ} \mathrm{C}$ por 4 minutos; $15^{\circ} \mathrm{C}$ por 1 minuto; $37^{\circ} \mathrm{C}$ por 4 minutos e $45^{\circ} \mathrm{C}$ por 1 minuto. Após a ciclagem, os dentes foram seccionados ao meio no sentido mesio-distal e a penetração do corante na interface dente/restauração foi avaliada e quantificada em $\mathrm{mm}$ usando a microscopia de imagem digital. Pelos resultados obtidos, os autores observaram que a infiltração foi maior na área de cemento e que nenhum dos materiais impediu a penetração do corante, porém o cimento de ionômero de vidro reduziu significantemente a microinfiltração nas margens das restaurações.

CRIM, G.A.; GARCIA-GODOY ${ }^{48}$, em 1987, compararam o efeito da estocagem dos dentes restaurados antes da ciclagem térmica e o número de ciclos na microinfiltração de resina composta. Realizaram preparos de classe $V$ nas cervicais (vestibular e lingual) de 20 pré-molares, as margens cavo-superficiais dos preparos foram localizadas todas em esmalte. A resina utilizada para a restauração foi a Prisma-fill. Depois de devidamente selados com esmalte de unha e papel alumínio, os dentes foram proporcionalmente divididos em grupos e tratados pelos seguintes métodos: Método A- os dentes restaurados foram imediatamente submetidos a 100 ciclos térmicos; Método Bos dentes restaurados foram imediatamente submetidos a 1500 ciclos térmicos; Método $C$ e D- os dentes foram estocados em temperatura ambiente por 24 horas depois ciclados por 100 ou 1500 cilclos, respectivamente. Um ciclo térmico consistiu de $23 \mathrm{~s}$. em $37^{\circ} \mathrm{C} ; 4 \mathrm{~s}$ em $54^{\circ} \mathrm{C}, 23 \mathrm{~s}$ em $37^{\circ} \mathrm{C}$ e $4 \mathrm{~s} \mathrm{em} 12^{\circ} \mathrm{C}$. Depois da ciclagem os dentes foram submersos em fucsina básica por 24 horas, e cada dente foi seccionado longitudinalmente na direção vestíbulolingual no centro das restaurações e avaliados com relação a quantidade de 
microinfiltração por meio de escores de 0 a 3 . 0 resultado deste trabalho revelou que o tempo de estocagem ou quantidade de ciclos não tem impacto significante no padrão de microinfiltração de resina composta.

PEARSON; LONGMAN ${ }^{150}$, em 1987, avaliaram os efeitos externos da aplicação de calor a um compósito durante a polimerização com relação à microinfiltração. Utilizaram 137 dentes extraídos, confeccionaram cavidades com $2 \mathrm{~mm}$ de diâmetro no terço médio desses dentes, nas faces vestibular e lingual. As cavidades foram restauradas por quatro métodos diferentes: 1) com bisel e sem condicionamento ácido; 2) cavidades iguais ao grupo 1 e o material misturado a $22^{\circ} \mathrm{C}$ e inserido, seguido da aplicação de um jato de ar quente de $65^{\circ} \mathrm{C}$ por 30 segundos; 3 ) depois do condicionamento ácido e bisel nas margens de esmalte da cavidade, o material foi manipulado e inserido seguindo instruções dos fabricantes; 4) cavidades iguais ao grupo 3 , mas o material e a inserção do mesmo como o grupo 2. Os dentes foram imediatamente polidos e termociclados em banhos de azul de metileno a $1 \%$ nas seguintes temperaturas e tempo de permanência; 4 segundos em $5^{\circ} \mathrm{C} ; 30$ segundos em $32^{\circ} \mathrm{C} ; 8$ segundos $65^{\circ} \mathrm{C}$ e 30 segundos em $32^{\circ} \mathrm{C}$. Os ciclos completos foram os seguintes: - 48 vezes em 1 hora; 22 horas representando 1 mês; 68 horas representando 3 meses; 136 horas representando 6 meses, e 272 horas representando 12 meses, "in vivo". Depois de termociclados os dentes foram seccionados longitudinalmente no sentido vestíbulo-lingual em no máximo três secções. As secções foram observadas com 20x e 100x de aumento e avaliadas seguindo escores de 1 a 4 . $O$ máximo de escore para a penetração do corante foi utilizado para cada restauração. Os autores concluíram que a infiltração parece ser cumulativa e está relacionada com o tempo. $O$ condiciomento ácido das margens em esmalte não parece ser efetivo para prevenir a microinfiltração após 3 meses de condições orais simuladas. A aplicação de calor antes da polimerização tem um efeito muito limitado na redução da infiltração. Após 12 meses de termociclagem simulada, nenhuma diferença foi notada em infiltração nos 4 grupos testados. O regime de termociclagem adotado apresentou infiltração consideravelmente maior do que outros estudos têm relatado. 
RETIEF $^{160}$, em 1987, com a finalidade de padronização dos métodos de avaliação da microinfiltração nas restaurações adesivas, revisou a literatura questionando a efetividade das técnicas adesivas na prevenção ou diminuição deste fator. Definiu adesão como o estado no qual duas superfícies se mantêm unidas pelas forças interfaciais químicas, mecânicas ou ambas. $O$ autor definiu o adesivo como sendo a substância capaz de manter os materiais unidos pela área que estão em contato. Caracterizou então o fenômeno adesivo como sendo resultante de uma união mecânica ou adesiva, onde as interações físico-químicas são estabelecidas entre um adesivo e a estrutura dentária. Avaliou inúmeros trabalhos sobre métodos de avaliação de microinfiltração "in vitro" de restaurações de resina composta e cimento de ionômero de vidro, e concluiu que na presença de esmalte, principalmente quando este se apresenta com uma boa espessura, o condicionamento ácido elimina a microinfiltração. Sugeriu então que os trabalhos realizados com este objetivo, tivessem suas margens cavitárias localizadas em dentina, apresentando uma forma não retentiva, e que os materiais empregados fossem utilizados conforme as instruções dos fabricantes. Com relação a técnica de inserção da resina composta, indicou a técnica oblíqua, com a qual se consegue aproximadamente $25 \%$ de redução das fendas marginais, e que as restaurações devem ser polidas pelo tempo mínimo de 15 minutos após a polimerização final do material. Para que os dentes sejam submetidos à ciclagem térmica, devem permanecer armazenados em água destilada por 24 horas para que ocorra a absorção de água pelo material, reduzindo assim o espaço entre o dente e o material restaurador. $O$ autor indicou que a ciclagem térmica deveria ser realizada preferencialmente em solução corante, por 500 ciclos e em temperaturas de $50^{\circ} \mathrm{C}$ e $8^{\circ} \mathrm{C}$, permanecendo em cada temperatura por 15 segundos, que segundo o autor no meio intrabucal as temperaturas não se mantêm por intervalos mais longos.

Em 1987, TROWBRIDGE ${ }^{196}$, discutiu em um artigo as causas da microinfiltração, examinou as condições sobre as quais a microinfiltração pode ser aumentada ou diminuída, fez uma revisão suscinta de técnicas que têm sido desenvolvidas para examinar falhas que se formam ao redor de 
restaurações, e considerou também os efeitos adversos da microinfiltração no esmalte, dentina e polpa. Sobre as causas da microinfiltração citou como a maior, a pobre adaptação dos materiais restauradores a estrutura dentinária, assim como a inexperiência do operador em inserir o material restaurador, a deformação elástica do material frente às forças mastigatórias, a profundidade e localização das cavidades e a extensão da infiltração marginal. Com relação aos métodos de avaliação de microinfiltração realizou uma breve revisão sobre os mais empregados, e os dividiu em três grandes categorias: 1) testes laboratoriais envolvendo passagem de corante isótopos radioativos, bactérias, ou ar através da fenda ao redor da restauração; 2) visualização direta do "gap"; 3) testes clínicos nos quais os efeitos biológicos são descritos. O autor considerou a ciclagem térmica um assunto não totalmente definido na literatura, mas ressaltou que a quantidade de microinfiltração observada em espécimes termociclados certamente não ocorre em condições clínicas. Conclui que as causas e conseqüências da microinfiltração requerem estudos adicionais. Para assegurar o papel da microinfiltração como um fator etiológico de doenças pulpares, mais informações são necessárias considerando a natureza, concentração, e toxicidade das substâncias que alcançam a polpa por meio dos túbulos dentinários. Crescentes evidências suportam a teoria de que, além da microinfiltração permitir que as bactérias se alojem nas paredes cavitárias, a maioria dos materiais restauradores são bem tolerados pela polpa.

BULLARD; LEINFELDER; RUSSEL ${ }^{26}$, em 1988, relataram a extensão da microinfiltração relacionando com a expansão e contração sofridas por alguns materiais quando submetidos a mudanças de temperatura. Seis diferentes materiais com coeficiente de expansão térmica linear variadas foram selecionados para serem avaliados (Tabela1). 
TABELA 1: Materiais utilizados e seus coeficiente de expansão térmico

\begin{tabular}{c|c|c}
\hline Material & Tipo & $\begin{array}{c}\text { Coeficiente de Expanção } \\
\left.\text { Térmico (10 }{ }^{-6}{ }^{\circ} \mathbf{C}\right)\end{array}$ \\
\hline Sevriton & Resina Acrílica & 80 \\
Silux & Resina Composta de Micropartículas & 5 \\
Fynal & Óxido de Zinco e Eugenol & 35 \\
Occlusin & Resina Composta & 21 \\
Gluster & Amálgama & 22 \\
Ketac-Fil & Ionômero de Vidro & 11 \\
\hline
\end{tabular}

Sessenta molares extraídos foram utilizados. Cavidades de classe V padronizadas foram confeccionadas, geralmente na face vestibular desses dentes (distância $M-D=5 \mathrm{~mm} ; 0-G=3 \mathrm{~mm}$ e profundidade $2 \mathrm{~mm}$ ). Todas as margens da cavidade foram localizadas em esmalte e não foram biseladas. Os dentes foram então divididos em 6 grupos e restaurados com os materiais selecionados. Os materiais foram manipulados de acordo com as recomendações do fabricante, somente nos casos em que foram usadas resinas compostas nenhum condicionamento ácido foi utilizado. Depois disto, os dentes tiveram seus ápices selados com amálgama e todas as suas superfícies cobertas com duas camadas de esmalte para unha, exceto $2 \mathrm{~mm}$ ao redor da restauração. Foram então estocados em água deionizada a $37^{\circ} \mathrm{C}$. Os dentes foram submetidos a termociclagem imersos em solução de fucsina básica, à temperatura de $5^{\circ} \mathrm{C}$ e $55^{\circ} \mathrm{C}$, permanecendo 1 minuto em cada banho, num total de 125 ciclos. Terminada a termociclagem, os dentes foram seccionados em dois planos diferentes e cada secção foi avaliada em um microscópio com 3 vezes de aumento e classificadas seguindo uma escala de escores graduados de 0 a 7 . Foram então examinadas duas secções de cada amostra, nas margens oclusal e gengival. Em ordem decrescente de microinfiltração, os materiais classificaram-se na seguinte ordem: Sevriton, com a média de penetração do corante 6.00; Silux, com 5.63; Fynal, com 4.85; Occlusin, com 4.20; Gluster, com 2.05; e Ketac-Fil, com 1.55. Depois de analisados estatisticamente, os resultados deste estudo sugeriram uma forte 
correlação entre o coeficiente de expansão térmica linear e a microinfiltração. Entretanto, muitos outros fatores contribuem com isso para os problemas clínicos, o coeficiente de expansão térmica linear poderia ser considerado como o fator principal.

A efetividade de um agente adesivo e um cimento de ionômero de vidro em reduzir a microinfiltração marginal das margens de restaurações de resina composta de Classe II foi examinado por DARBYSHIRE; MESSER; DOUGLAS ${ }^{52}$, em 1988. O efeito de cargas ciclicas (térmica e carregamento) na microinfiltração dessas restaurações também foram avaliadas. As cavidades foram restauradas em pré-molares, humanos, extraídos, com a margem cervical localizada aproximadamente $1 \mathrm{~mm}$ abaixo da junção amelo-dentinária. Combinações de sistemas adesivos, cimento de ionômero de vidro, e um controle (sem forramento) foram usados como medidores entre resina e dentina. Todas as restaurações foram inseridas incrementalmente com 40 segundos de fotopolimerização por incremento e o acabamento foi realizado com ponta diamantada em alta velocidade. Metade das amostras de cada grupo receberam cargas axiais cíclicas e a outra metade não. Todas as amostras foram termocicladas a $5^{\circ}$ e $55^{\circ} \mathrm{C}$ por 500 ciclos, permanecendo 1 minuto em cada banho, corados por 4 horas em $50 \%$ de $\mathrm{AgNO}_{3}$, e seccionados para exame da penetração do corante. A análise foi seguindo escores préestabelecidos. Todas as restaurações exibiram microinfiltração e não foram afetadas pelos carregamentos cíclicos. O sistema adesivo e o cimento de ionômero de vidro reduziram significantemente a microinfiltração. Quando o cimento de ionômero de vidro estava presente, a presença adicional do adesivo não promoveu uma diferença estatisticamente significante na redução da microinfiltração.

SMITH et al. ${ }^{181}$, em 1988 avaliaram a microinfiltração de dois novos sistemas adesivos. Preparos de Classe $V$ sem retenção mecânica foram feitos em 120 pré-molares. 60 dos dentes foram restaurados com o sistema restaurador Gluma/Lumifor seguindo instruções dos fabricantes. Os outros 60 dentes foram restaurados com o sistema restaurador Tenure/Perfection, 
seguindo também as instruções dos fabricantes. 15 restaurações de cada grupo foram polidas 15 minutos depois e submetidas a 250 ou 500 ciclos; 15 restaurações polidas depois de 24 horas e submetidas a 250 ou 500 ciclos em $0,5 \%$ de fucsina básica entre $7^{\circ}$ e $50^{\circ} \mathrm{C}$. A seguir, quatro secções foram feitas de cada restauração e a microinfiltração medida por escores de 0 a 4 em esmalte e cemento. 59 restaurações com o sistema Gluma/Lumifor não mostraram microinfiltração nas margens de esmalte enquanto 16 não mostraram na margem de cemento. A microinfiltração no cemento das restaurações foi significantemente maior do que nas margens de esmalte. Tempo de acabamento e número de ciclos não tiveram diferenças significantes no efeito da microinfiltração.

\section{Em 1988, TORSTENSEN; BRANNSTRÖM ${ }^{195}$, avaliaram as} variações dimensionais das fendas marginais nas restaurações com resinas compostas, quando submetidas a variações de temperatura. Cavidades de Classe $V$ com margens gengivais estendidas $1 \mathrm{~mm}$ além da junção esmaltecemento foram preparadas nas faces livres de noventa e dois molares humanos, sendo os mesmos divididos em dois grupos. O primeiro destinado ao estudo da largura do microespaço resultante após o armazenamento dos espécimes em água e, o segundo com a finalidade de avaliar a dimensão do microespaço na interface das restaurações, após os espécimes terem sido expostos a baixas temperaturas. Foram utilizadas resinas compostas híbridas e de micropartículas, foto e quimiopolimerizáveis. As interfaces das restaurações foram impregnadas com uma solução fluroscente adicionada a um adesivo para esmalte e, posteriormente, os espécimes armazenados em água destilada a $37^{\circ} \mathrm{C}$ por duas ou três semanas, as interfaces dos espécimes que sofreram resfriamento foram novamente impregnadas com corante fluorescente. Pelos resultados, observou-se que as resinas compostas de micropartículas apresentaram um índice reduzido de infiltração marginal após o armazenamento em água por três semanas, o que se deve provavelmente à sua melhor propriedade de expansão higroscópica. Para as resinas híbridas, a maioria dos espécimes não apresentaram redução da infiltração, sendo esta levemente minimizado em poucas restaurações. Com relação aos espécimes 
expostos ao frio, não houve diferença quanto ao índice de infiltração marginal para os tipos de resina estudadas (Scotchbond/Silar e Brilliant/Margin Bond).

HANSEN; ASMUSSEN ${ }^{91}$, em 1988, realizaram uma pesquisa para determinar qual seria o intervalo de tempo adequado para dar acabamento e polimento em restaurações de resina composta. Usaram dentes humanos extraídos e materiais restauradores adesivos. Encontrando valores diferentes no tamanho das fendas marginais dos materiais, concluíram que era necessário aguardar o fechamento desta interface pela expansão hidroscópica da resina antes de dar acabamento e polimento, e que isto levaria mais de 60 minutos.

\section{Em 1989, LITKOWSKI; McDONALD; SWIERCZEWSKI ${ }^{12}$,} compararam a influência da termociclagem na microinfiltração de três adesivos dentinários Scotchbond II, Gluma e Tenure. Confeccionaram cavidades circulares em superfícies radiculares e restauraram com Herculite, as cavidades foram divididas em 3 grupos de acordo com o adesivo utilizado. Metade das amostras de cada grupo foram termocicladas em $5^{\circ} \mathrm{C}$ e $55^{\circ} \mathrm{C}$, 50.000 vezes e permaneceram 60s em cada temperatura. A outra metade foi mantida à $37^{\circ} \mathrm{C}$ pelo mesmo tempo. Analisando os resultados, concluíram que a termociclagem influenciou significantemente, aumentando a microinfiltração dos adesivos Scotchbond II e Gluma, o que não ocorreu com o Tenure.

Em 1990, KOIKE et al. ${ }^{106}$, avaliaram o efeito da alteração do volume dos compósitos causada pela sorpção de água na adaptação às paredes cavitárias. Utilizaram a medida da largura do microespaço entre a resina composta e a parede dentinária da cavidade. Prepararam cavidades cilíndricas na face proximal de molares extraídos e limpos com EDTA a 0,5M por 60 segundos. Os dentes foram divididos em grupos. O grupo controle foi restaurado com resina composta fotoativada sem o uso de primer ou resina intermediária. Depois de restaurados, os espécimes foram estocados em água à temperatura ambiente; passadas 0.5, 24 e 48 horas de estocagem, as restaurações foram polidas. A largura do microespaço de contração foi medida 
por um micrômetro montado na ocular de um microscópio com aumento de 1024 vezes. A contração do compósito foi indicada em porcentagem. Nos grupos experimentais, a dentina foi limpa com EDTA e pré-tratada com três primers experimentais (um para cada grupo): solução aquosa de hydroxietilmetacrilato à 35\% (HEMA); mistura aquosa de 35\% de HEMA e 5\% de glutaraldeído; ou solução aquosa de gliceril metacrilato a 35\% (GM) por 60 segundos. As cavidades foram então secas com um jato de ar, e uma fina camada de Clearfil New bond foi aplicado antes do material restaurador. $O$ microespaço de contração foi medido com o mesmo aparato do grupo controle, mas após 1, 2, 4 e 6 horas de estocados em água. Para medir o microespaço de contração após a ciclagem térmica, os espécimes foram preparados da mesma forma dos citados anteriormente para os grupos experimentais e estocados em água à $10^{\circ} \mathrm{C}$ por $1,2,4$ e 6 horas. Depois disto foram ciclados 60 vezes em banhos de água a temperaturas de $10^{\circ} \mathrm{C}$ e $45^{\circ} \mathrm{C}$, permanecendo 30 segundos em cada banho. Imediatamente após a ciclagem, os microespaço de contração foram medidos da mesma forma já descrita. Analisando os resultados, os autores encontraram que no grupo controle onde não utilizaram nenhum primer nem adesivo, o microespaço de contração inicial fechou completamente após 48 horas pela sorpção da água, no grupo experimental com o primer GM, um completo selamento foi obtido em todos os espécimes testados uma hora depois da polimerização do compósito. Além disso a adaptação conseguida com este primer não foi destruída depois da ciclagem térmica. Nos outros dois grupos experimentais o microespaço de contração fechou rapidamente e depois de seis horas de estocados em água e termociclados, nenhum microespaço foi observado. Concluíram também que o uso de primers e adesivos dentinários reduzem significantemente 0 microespaço de contração inicial.

MOMOI et al. ${ }^{131}$, em 1990, mediram o efeito do stresse térmico na infiltração marginal de restaurações de resina composta em dentes bovinos por meio de ciclagem térmica e um método de condutibilidade elétrica. Quatro resinas para dentes posteriores foram utilizadas para restaurar cavidades cilíndricas confeccionadas na face vestibular de incisivos bovinos, seguindo 
instruções do fabricante. As resinas utilizadas foram as seguintes - uma resina quimicamente fotopolimerizável - Clearfil Photo Posterior, e três fotopolimerizáveis - Clearfil Photo Posterior, P-30 e P-50. A ciclagem térmica foi aplicada aos espécimes por sete semanas, totalizando 9000 ciclos, e cada ciclo constituido das seguintes temperaturas: 1 minuto em $37^{\circ} \mathrm{C}$; 8 minutos em $4^{\circ} \mathrm{C}$; 1 minuto em $37^{\circ} \mathrm{C}$ e 2 minutos em $60^{\circ} \mathrm{C}$. Pelo mesmo período 19 espécimes foram mantidos em solução salina a $37^{\circ} \mathrm{C}$ sem ciclagem térmica e foram considerados como o grupo controle. A infiltração marginal foi medida para todos os grupos antes da ciclagem com 1, 25, 50, 75, 100, 1000 e 9000 ciclos. Antes do início da ciclagem térmica as resinas compostas testadas apresentavam pequena infiltração marginal, sendo que a resina quimicamente polimerizável foi a que apresentou menor infiltração. Com o stresse térmico de apenas um ciclo não houve aumento na infiltração marginal. Depois de 25 ou 50 ciclos, a infiltração marginal em todos os espécimes mostraram significante aumento e assim aumentando gradualmente até os 9000 ciclos. As quatro resinas compostas testadas mostraram um grau similar de infiltração marginal. Os espécimes com as maiores infiltrações marginais antes da aplicação do stresse térmico, mostraram os maiores aumentos na infiltração marginal com stresse térmico e vice-versa. Não houve diferenças significantes entre as quatro resinas compostas. No grupo controle não foi encontrado aumento na infiltração marginal, com o período testado.

Com a finalidade de avaliar e comparar a capacidade de união dos sistemas adesivos Scotchbond 2/Silux, Gluma/Lumifor e Tenure/Perfection, RIGSBY et al. ${ }^{167}$, em 1990, determinaram a microinfiltração qualitativa e quantitativa, além do tamanho das fendas marginais em restaurações de classe $\mathrm{V}$, padronizadas e confeccionadas usando estes sistemas. Um total de 90 caninos humanos extraídos foram utilizados neste estudo, sendo distribuídos em 30 para cada teste. Os sistemas adesivos dentinários foram aplicados seguindo as recomendações dos fabricantes e as restaurações das cavidades realizadas com as respectivas resinas compostas. Para os testes de microinfiltração, selaram os espécimes com restaurações de verniz/amálgama e aplicaram duas camadas de esmalte sobre toda a superfície do dente, $1 \mathrm{~mm}$ 
além da margem da restauração, com objetivo de que o corante penetrasse somente nesta área. Antes de avaliar a microinfiltração qualitativa, os dentes foram termociclados (500 ciclos) embebidos em fucsina básica a $0,5 \%$ entre $8^{\circ} \mathrm{C}$ e $55^{\circ} \mathrm{C}$, sendo usado o mesmo procedimento no caso da microinfiltração quantitativa porém trocando o corante por azul de metileno a $2 \%$. A dimensão das fendas marginais foi observada através do microscópio eletrônico de varredura. Os resultados revelaram que o Scotchbond 2 apresentou os valores mais baixos em todos os testes, não apresentando diferenças estatisticamente significantes com o Tenure, mas ambos apresentaram valores mais baixos que o Gluma.

Com a finalidade de determinar a capacidade de vedamento marginal de cinco sistemas restauradores adesivos, SOUZA JÚNIOR et al. ${ }^{182}$, em 1991, empregaram 40 pré-molares humanos extraídos onde prepararam cavidades de Classe II (MOD) padronizadas, com a parede gengival localizada $2 \mathrm{~mm}$ acima da junção cemento/esmalte em uma das caixas proximais e $2 \mathrm{~mm}$ abaixo na outra caixa. Cinco grupos de oito dentes foram restaurados seguindo as instruções dos fabricantes para cada sistema. Posteriormente os dentes foram isolados com duas camadas de Araldite e uma de esmalte cosmético aplicadas sobre toda a superfície dentária, $2 \mathrm{~mm}$ além da margem da restauração. Em seguida, os espécimes foram armazenados em saliva artificial a $37^{\circ} \mathrm{C}$ por 24 horas. Depois foram submetidos a 105 ciclos térmicos $\left(5^{\circ} \mathrm{C} \mathrm{e}\right.$ $55^{\circ} \mathrm{C}$ ) por uma semana, sendo o último ciclo no corante (Rhodamina B a $0,1 \%$ ). Após seccionados, os dentes foram observados em microscópia por meio da técnica de fluorescência. Dos grupos avaliados, para as margens de esmalte, comportaram-se melhor as combinações ionômero de vidro/Scotchbond/P30, Scotchbond/P30 e Bondilite/Herculite, quando comparados com o sistema Gluma/Lumifor. Nas margens de cemento, o sistema ionômero de vidro/Scotchbond/P30, foi o que apresentou um melhor desempenho ao ser comparado com os sistemas ARM/Adaptic e Gluma/Lumifor. Concluíram que nenhum dos sistemas restauradores adesivos estudados foi capaz de impedir totalmente a microinfiltração, sendo esta mais significante nas margens de cemento. 
$\mathrm{Na}$ tentativa de padronizar os testes de adesão de laboratório devido à grande variação de metodologias que dificulta e não permite a comparação dos resultados dos diferentes estudos, RETIEF ${ }^{161}$, em 1991, descreveu a metodologia de testes de cizalhamento, microinfiltração marginal e avaliação da dimensão do microespaço marginal na interface dente/restauração. Com relação aos testes de cisalhamento, o autor considera que as forças sofridas pela restauração clinicamente não são reproduzidas em laboratório, mas os considera atualmente mais precisos, apesar de concordar que a resina composta unida à superfície de dentina ao sofrer carregamento ou tensão, tem o stresse distribuido ao longo da interface de forma extremamente irregular. Quanto ao fato de alguns pesquisadores estarem usando dente bovino em testes de adesão pela dificuldade de se conseguir dentes humanos extraídos e intactos, cita vários resultados de trabalhos que concluíram não haver diferenças significantes entre os testes de cisalhamento no esmalte e dentina de ambos. O período de estocagem dos dentes até a realização dos preparos também foi comentado, e com base em alguns estudos concluíram não haver diferença na estocagem de dois dias e 6 meses. Os líquidos para estocagem mais comum são:- formalina, cloramina, álcool, soro fisiológico e timol, de acordo com o autor, somente ocorreram diferenças significantes nos testes de cisalhamento quando os dentes foram estocados em álcool $70 \%$. Considerou como decisivo a seleção da área do dente a ser preparado devido ao tamanho dos túbulos, relatou que nas superfícies proximais de molares não foram notadas diferenças significantes, quando comparados com a dentina da superfície oclusal. A rugosidade superficial da dentina também pode influenciar nos testes de cisalhamento, entretanto considerou este fator muito controverso na literatura. Outro parâmetro crítico que afeta consideravelmente a adesão, segundo o autor, é a espessura da dentina depois de preparada, vários estudos comprovaram que quanto mais próximo da polpa, menores os valores encontrados, provavelmente pelo diâmetro e número dos túbulos dentinários desta região. A área de demarcação para a união também pode afetar a adesão, e o excesso de material nas margens desta área pré-determinada pode aumentar significantemente o valor do teste, citou como diâmetro ideal para o teste uma área circular de $3 \mathrm{~mm}$. A aplicação do sistema adesivo, de 
acordo com o autor deve seguir as instruções do fabricante. Sua última consideração sobre os testes de cisalhamento foi sobre as bases aplicadoras da força que pode ser retangular ou em forma de ponta de faca, alguns estudos mostraram que a segunda apresentou resultados maiores. Sugeriu que para ficar mais fácil a comparação entre os dados de trabalhos diferentes, os resultados fossem expressos em Mpa. Ao examinar a literatura com relação aos testes de microinfiltração encontrou uma enorme variação de testes, a começar pela localização das margens do preparo que podem ser abrangendo esmalte e dentina ao longo da junção amelo-dentinaria, entretanto a ADA, estipulou que para testes com materiais adesivos dentinários, o preparo deverá ser exclusivamente em dentina. Os procedimentos restauradores devem seguir as instruções do fabricante e a restauração realizada em 2 fases e a resina aplicada de forma oblíqua que reduz em aproximadamente 25\% o microespaço marginal. O acabamento das restaurações pode ser realizado 15 minutos após o final da polimerização e depois estocado em água destilada por 24 horas antes da ciclagem, diminuindo substancialmente o microespaço marginal. A ciclagem ideal segundo o autor seria de 500 ciclos com banhos entre $\pm 50^{\circ} \mathrm{C}$ e $\pm 8^{\circ} \mathrm{C}$, permanecendo 15 segundos em cada banho, isto porque nenhum alimento permanece intra-oralmente por um tempo maior que este. Com relação a metodologia de leitura da infiltração citou os métodos qualitativo e quantitativo, sendo este último mais preciso. Finalmente ao analisar testes que avaliam a dimensão dos microespaços marginais na interface dente/restauração recomendou o método de van Dijken e Horstedt, que utilizam réplicas de resina epóxica.

BURKE $^{31}$, em 1991, publicou uma revisão do modo de ação dos adesivos dentinários e detalhes de técnicas clínicas para algumas aplicações. Depois de discorrer sobre estes assuntos, o autor concluiu que os adesivos de $3^{\mathrm{a}}$ geração mostraram-se promissores como materiais adesivos, aumentando a união a dentina quando comparados com materiais anteriores. Alguns sistemas têm sua técnica mais sensível e consomem mais tempo que outras e cabe a cada dentista a escolha do sistema a que melhor se adaptar, e ao sistema de maior custo-benefício. A adesão dos novos adesivos com relação ao esmalte 
não sofreu grandes melhoras. Entretanto, eles são de grande valia em situações clínicas onde há pouco esmalte, e em lugar de grandes áreas de dentina, ou situações onde há pequenas áreas críticas de dentina (como na caixa proximal de cavidades profundas de Classe II). Nestas circunstâncias, parece que os adesivos dentinários podem ser de grande valia para otimizar o uso dos materiais compósitos.

Em 1991, MANDRAS; RETIEF; RUSSELL ${ }^{116}$, avaliaram a microinfiltração do sistema adesivo Scotchbond 2, em várias condições experimentais. Neste estudo "in vitro", restaurações de Classe V envolvendo esmalte e cemento foram confeccionadas na superfície vestibular de 54 caninos extraídos e na superfície vestibular e lingual de 8 molares inferiores. Os caninos foram divididos em três grupos que diferenciaram-se nas condições da termociclagem e tempo de estocagem do corante. Grupo A: 18 dentes restaurados e termociclados por 250 ciclos em solução de fucsina básica em temperaturas de $8^{\circ} \mathrm{C}$ e $55^{\circ} \mathrm{C}$ com 15 segundos em cada banho; Grupo B: 18 dentes restaurados, termociclados 500 vezes nas mesmas condições do Grupo A e então estocados por uma noite em solução de fucsina básica a $0,5 \%$. No dia seguinte foram termociclados uma segunda vez por 500 ciclos e novamente estocados por uma noite em solução corante; Grupo C: 18 dentes restaurados, termociclados 500 vezes em água destilada nas mesmas condições do Grupo A. Eles foram então estocados por uma noite em solução de fucsina básica a $0,5 \%$. No dia seguinte, os dentes foram lavados e termociclados uma segunda vez por mais 500 ciclos e então novamente estocados por mais uma noite em solução corante. Um quarto grupo foi confeccionado com os molares, foram realizadas as cavidades de Classe $\mathrm{V}$ na vestibular e lingual destes dentes e eles foram montados em cilindros com resina acrílica e cargas verticais de $8 \mathrm{MPa}$ por 66 vezes de 10s cada foi aplicado à superfície oclusal destes, e em seguida foram termociclados por 250 ciclos em solução de fucsina básica a 0,5\%, como no Grupo A. Depois deste, os espécimes foram seccionados, avaliados e classificados por escores de 0 a 4 . Não houve diferença estatística na microinfiltração das restaurações dos grupos; entretanto, a microinfiltração 
do grupo dos molares submetidos a estresse oclusal foi significantemente maior.

Em 1991, CASTAÑEDA ${ }^{35}$, verificou a influência da contração de polimerização presente em restaurações de resina composta, associada a algumas variáveis, sobre a habilidade de selamento em restaurações de classe V seguindo a técnica do "sandwich". Os preparos cavitários apresentaram margens em esmalte e em dentina/cemento. Os dentes humanos após restaurados, sofreram termociclagem $\left(5^{\circ} \mathrm{C}-55^{\circ} \mathrm{C}\right)$ e foram imersos em solução de fucsina básica a $2 \%$ por 24 horas. O grau de microinfiltração foi observado através do microscópio óptico e registrada com critérios qualitativos de 0 a 3 , nas margens de esmalte, de 0 a 4 nas margens de dentina e de 0 a 1 na interface resina/ionômero de vidro. Os resultados demonstraram que o cimento de ionômero de vidro utilizado como único material restaurador, não foi capaz de prevenir a microinfiltração severa em ambas as margens. As restaurações com a técnica do "Sandwich" foram significantemente melhores, também em ambas as margens porém a microinfiltração foi menos freqüente no esmalte. Concluiu que o cimento de ionômero de vidro, o desenho cavitário e a termociclagem não modificaram a intensidade da microinfiltração.

Em 1992, RETIEF et al. ${ }^{162}$, determinaram os efeitos do condicionamento ácido com ácido fosfórico em dentina na resistência ao cisalhamento e na microinfiltração quantitativa em um sistema adesivo dentinário experimental, e avaliaram os efeitos dos procedimentos restauradores na dentina por meio de microscópio eletrônico de varredura. 30 primeiros e segundos molares permanentes foram usados para a avaliação da resistência ao cisalhamento. Em 15 desses dentes foi aplicado Dentina Conditioner na dentina por 30 segundos $(A)$, enquanto nos outros 15 dentes remanescentes a "smear layer" foi removida pela aplicação de $\mathrm{H}_{3} \mathrm{PO}_{4}$ à $37 \%$ por 20 segundos (B). Os primers 1 e 2 foram misturados e aplicados como condicionador dentinário seguido da aplicação do adesivo dentinário antes da colocação em três incrementos da resina Bisfil-M. Os espécimes foram estocados em soro fisiológico a 37\%, por 24 horas antes da aplicação do 
carregamento para o teste de cisalhamento na máquina Instron com velocidade de $0,5 \mathrm{~mm} / \mathrm{min}$. Preparos de classe $V$ circulares foram realizados na raiz de 30 caninos permanentes, 15 restaurados usando o Dentin Conditioner (C) e 15 remoção da "smear layer" com o $\mathrm{H}_{3} \mathrm{PO}_{4}(\mathrm{D})$. Depois de restaurados, os dentes foram colocados em solução salina a temperatura ambiente por 24 horas. Passado este período, os mesmos foram polidos e preparados para a ciclagem térmica. A ciclagem foi realizada em solução de azul de metileno a $2 \%$ em temperaturas de $8^{\circ} \mathrm{C}$ e $50^{\circ} \mathrm{C}$, permanecendo 15 segundos em cada banho por 500 vezes. A microinfiltração foi determinada quantitativamente por meio de um método espectofotométrico. Os autores encontraram os seguintes resultados: A) $14.2 \pm 2.2 \mathrm{MPa}$; B) $7.2 \pm 4.2 \mathrm{MPa}$ : C) $30.0 \pm 28.6 \mu \mathrm{g}$ de corante por restauração: D) $10.3 \pm 8.2 \mu \mathrm{g}$ de corante por restauração. Concluíram então que a remoção da "smear layer" com $\mathrm{H}_{3} \mathrm{PO}_{4}$ reduziu a resistência ao cisalhamento da dentina mas diminuiu a microinfiltração significantemente.

Com o propósito de avaliar a interferência da "smear layer" na união da dentina, DAVIS et al. ${ }^{54}$, em 1992, compararam a resistência de união de sistemas adesivos dentinários (All bond, Prisma Universal Bond 2, Mirage Bond e Scotchond 2) que atuam sobre a "smear layer" sem removê-la, aplicando-os na superfície da dentina tratada seguindo instruções dos fabricantes; condicionando com ácido fosfórico a 10\%; com ácido poliacrílico a $40 \%$, ou eliminando totalmente a "smear layer". A dentina oclusal exposta de 120 molares humanos extraídos foi cortada com uma broca, produzindo uma textura superficial e uma "smear layer" similar às encontradas clinicamente. Depois de aplicados os adesivos, foram condensados e fotopolimerizados cilindros de resina composta através de dispositivos apropriados. Prontos, os corpos de prova foram armazenados em água a $37^{\circ} \mathrm{C}$ por 24 horas, sendo realizados posteriormente os testes de resistência ao cisalhamento. Os menores valores de resistência de união apareceram nos grupos condicionados com ácido poliacrílico quando comparados com os outros dois grupos, os quais foram similares estatisticamente. Os autores concluíram que o ácido fosfórico prepara melhor a dentina para os agentes adesivos do que o ácido poliacrílico. Também observaram que o emprego destes sistemas 
adesivos, como indica o fabricante, sem remover totalmente a "smear layer", somente tratando-a, resultou em valores semelhantes ao da sua completa eliminação.

TAYLOR; LYNCH ${ }^{191}$, em 1992, publicaram uma revisão dos diferentes métodos utilizados para avaliar a microinfiltração na interface dente/material restaurador. Consideraram as vantagens e desvantagens das técnicas empregadas, tais como: testes usando bactérias, ar comprimido, traçadores radioativos ou químicos, testes eletroquímicos, microscopia eletrônica de varredura e análise da penetração de corantes. Esta última, sendo a mais utilizada de todas. Comentaram que a técnica de penetração de corantes permite avaliar a infiltração por meio de substâncias que produzem cores contrastantes com a superfície do dente e da restauração sem precisar de uma reação química ou radiação, como no caso, por exemplo, dos traçadores químicos. Porém, é uma técnica considerada sensível, subjetiva na interpretação e difícil de padronizar, além de que uma fatia do dente só permite uma análise bidimencional e não tridimencional da restauração. A solução de fucsina básica tem sido um dos corantes mais usados. Afirmaram que os estudos da microinfiltração têm sido realizados com ciclagem térmica e mecânica, com diferenças na seleção dos ciclos e temperaturas pelos pesquisadores. Concluíram que seria muito importante continuar trabalhando para alcançar padronização e aperfeiçoamento para os métodos de avaliação da microinfiltração.

Em 1992, CHRISTENSEN ${ }^{41}$, enumerou e discutiu vários fatores clínicos que interferem na adesão ao dente. Fatores tais, que podem ser ou não controlados pelo dentista. Entre eles, citou a contaminação indesejável por saliva e/ou sangue da superfície adesiva, o que produz inadequada união mesmo em dentina úmida. Também explicou sobre os efeitos da contaminação da água e óleo provenientes da seringa, do ar ou da peça de mão (alta rotação), assim como dos efeitos da desidratação dentinária, o uso de bases ou forramentos em relação à influência dos componentes dos cimentos temporários. Afirmou que a presença de rugosidades nas superfícies dos 
tecidos dentinários aumenta a área para adesão sendo um fator favorável como as retenções secundárias que evitam o deslocamento da restauração. Concluiu que os profissionais devem permanecer atentos a esses fatores $\mathrm{e}$ orientar a prática clínica ao controle dos mesmos para atingir o sucesso dos serviços por eles prestados.

A microinfiltração em restaurações de resina composta de classe $\mathrm{V}$ submetidas a ciclagens de temperatura e de carregamentos axiais foi avaliada por RIGSBY et al. ${ }^{168}$, em 1992. Os preparos foram feitos nas superfícies mesial e distal de 29 primeiros e segundos molares. As margens de esmalte foram biseladas, condicionadas, lavadas e secas. O sistema adesivo XR Bonding (Kerr) foi aplicado à dentina e ao esmalte condicionado e a resina Herculite polimerizada em dois incrementos. Os dentes foram estocados em solução salina por 7 dias, termociclados por 500 vezes em fucsina básica à $0,5 \%$ entre $8^{\circ} \mathrm{C}$ e $50^{\circ} \mathrm{C}(\mathrm{A})$; submetidos a carregamento oclusal de $34 \mathrm{MPa}$ no corante sem termociclagem (B); ou seguindo por termociclagem (C). A microinfiltração foi avaliada por escores de 0 a 4 na superfície do esmalte e de cemento. Por este estudo concluíram que não ocorreu microinfiltração nas margens em esmalte das restaurações submetidas ao estresse térmico ou de carregamento ou com a combinação de ambos; nas margens em cemento a microinfiltração não foi significantemente diferente, quando os dentes foram submetidos aos estresses térmicos e de carregamento, mas foi significantemente aumentada, quando submetidos a ambos, a tensão nas margens de esmalte de restaurações de classe $\mathrm{V}$ em dentes submetidos a estresse oclusal foram geralmente menores que a observada nas margens em cemento das restaurações.

Para determinar o efeito do aumento de ciclos da termociclagem na força de união da resina composta com a dentina utilizando um agente de união com NTG-GMA/BPDM (All Bond), BURGER; COOLEY; GARCIAGODOY $^{30}$, em 1992, utilizaram 50 molares humanos com a superfície vestibular cortada com uma lixa 600 em dentina. 10 espécimes foram preparados para cada grupo e os adesivos utilizados de acordo com instruções 
do fabricante. Uma matriz de formato cilíndrico foi usada para a inserção da resina composta sobre a superfície de dentina tratada e polimerizada por $30 \mathrm{~s}$. Depois de estocados por 24 horas em água deionizada a $37^{\circ} \mathrm{C}$, os espécimes foram termociclados a $6^{\circ} \mathrm{C}$ e $60^{\circ} \mathrm{C}$, em cinco grupos diferentes com 100, 500, 2.000 e 4.000 ciclos. A força de união foi determinada com a máquina Instron em uma velocidade de $0,5 \mathrm{~mm} /$ minuto. Os autores concluíram que o aumento no número de ciclos não afetou a força de união do sistema adesivo testado.

MANDRAS; RETIEF; RUSSELL ${ }^{117}$, em 1992, avaliaram a microinfiltração de adesivos dentinários "in vitro", usando uma técnica com corante e espectrofotometria. Realizaram preparos de classe $V$ com $3 \mathrm{~mm}$ de diâmetro e 1,5mm de profundidade, na superfície vestibular das raízes de 90 caninos permanentes extraídos. Os grupos foram os seguintes: AGluma/Pekafill; B- Tripton/Opalux; C- Syntac/Heliomolar; D- Prisma Universal Bond 2/Prisma AP.H; E- Prisma Universal Bond 3/Prisma AP.H; F- Clearfil Photo Bond/Photo Clearfil Bright. Os dentes foram ciclados 500 vezes em azul de metileno a $2 \%$, depois as raízes foram seccionadas e colocadas em $\mathrm{HNO}_{3}$ a $50 \%$ para extração do corante, e a concentração do corante foi determinado por um espectrofotometro. A solução padrão utilizada foi obtida por uma raiz sem restauração. Os dados foram analizados pelo teste ANOVA e Duncan's e os resultados expressos em $\mu \mathrm{g}$ de corante/restauração. Concluíram que os adesivos Clearfil Photo Bond e Prisma Universal Bond 3 mostraram significantemente menos infiltração que os outros sistemas avaliados.

Em 1992, WENDT; McINNES; DICKINSON ${ }^{202}$, avaliaram o efeito da termociclagem na penetração do corante "in vitro" com microinfiltração em compósitos. 50 molares humanos não cariados, estocados em 75\% de etanol, divididos em 5 grupos. Realizaram preparos MOD onde uma margem cervical localizava-se em cemento e a outra em esmalte. As margens em esmalte foram condicionadas, lavadas e secas e a resina inserida e polimerizada em múltiplos incrementos. O grupo A não foi termociclado e foi imerso em fucsina básica a $0,5 \%$ por 24 horas à $37^{\circ} \mathrm{C} \pm 1^{\circ} \mathrm{C}$; grupo $\mathrm{B}$ foi termociclado em banhos de água e imerso em corante como o grupo $A$; o grupo $C$ foi termociclado em banhos de 
fucsina básica. A termociclagem constituiu em 250 ciclos de $15 \mathrm{~s}$ em temperaturas de $5^{\circ} \mathrm{C}$ e $50^{\circ} \mathrm{C}$. Em seguida os dentes foram montados em acrílico e seccionados em múltiplos cortes. A penetração do corante foi avaliado por uma escala de 0 (sem infiltração) à 4 (infiltração na parede pulpar) e a média foi calculada para cada superfície e dentes. Neste estudo, não houve diferença significante na microinfiltração quando usada a termociclagem, nem em banhos com água ou corante, quando comparada com restaurações não termocicladas.

Em 1992, CHAN; GLYN JONES ${ }^{38}$, compararam quatro testes de infiltração marginal comumente usados e avaliaram sua adaptabilidade para o uso em restaurações de superfície radicular. 40 pré-molares extraídos foram utilizados, depois de suas raízes serem limpas com pedra-pomes e água, cavidades de classe $\mathrm{V}$ foram preparadas nestas regiões com ângulo cavosuperficial em $90^{\circ} \mathrm{com}$ as faces vestibular, lingual e distal de cada dente, sempre abaixo da junção cemento-esmalte. Cada uma das quatro cavidades foi restaurada com um material diferente:- amálgama ANA 2000; cimento de ionômero de vidro Ketac-Fil; adesivo Tripton e resina hibrida Opalux; adesivo Gluma e resina de micropartícula PeKalux. Depois de restaurados os dentes foram colocados em solução salina a temperatura ambiente por 24 horas e então as restaurações, com exceção do amálgama, foram polidas com discos soft-lex. Todos os dentes foram submetidos à ciclagem térmica por 24 horas (aproximadamente 150 ciclos) com as seguintes temperaturas e tempo de banho:- $45^{\circ} \mathrm{C}$ ( 1 minuto); $37^{\circ} \mathrm{C}$ (4 minutos); $15^{\circ} \mathrm{C}$ (1 minuto); $37^{\circ} \mathrm{C}$ (4 minutos). Em seguida os dentes foram armazenados por 1 semana em solução salina à temperatura ambiente. Depois disto, os ápices foram selados com cera e a superfície do dente coberta com duas camadas de esmalte para unha, exceto 1 $\mathrm{mm}$ ao redor da restauração. Os dentes foram então divididos arbitrariamente em 4 grupos com 10 dentes cada: Grupo 1: os dentes foram imersos por 1 hora em corante de eosina a 5\% com pH 7,4; Grupo 2: imersos em solução de nitrato de prata a $50 \%$ por 2 horas. Lavados e expostos à luz natural e fluorescente por 3 horas; Grupo 3: imersos em gelatina com pH ajustado em 4,5 com adição de 0,02M de ácido lático e hidróxido de sódio por 8 semanas: 
Grupo 4 - imersos em uma solução radioativa de cloreto de cálcio com $0,1 \mathrm{~m} \mathrm{Ci}$ $\mathrm{ml}^{-1}$ por 2 horas, o pH foi ajustado em 7,0 para evitar a desmineralização do cemento. Os dentes do grupo 1, 2 e 3 foram seccionados transversalmente no meio das restaurações. Os grupos 1 e 2 foram analisados em um microscópio com 2 vezes de aumento. Secções de aproximadamente $80 \mu \mathrm{m}$ foram produzidas dos espécimes expostos à gelatina acidificada, e foram examinadas por um microscópio de luz polarizada com 25 vezes de aumento. Os espécimes expostos ao radiocálcio foram seccionados com discos de diamante e as secções foram colocadas diretamente no filme Ultra-speed e foram examinadas com 2 vezes de aumento. $O$ sistema de escores utilizado variou de 0 a 4 . Um mesmo operador avaliou os cortes em três ocasiões diferentes, o escore mais alto de cada restauração foi utilizado para a análise. Ocorrendo desacordo na leitura ou grande disparidade, a média dos escores foi usada. De posse dos resultados, os autores concluíram que:- nenhum dos testes avaliados pareceu ser ideal para demonstrar infiltração marginal associado com restaurações radiculares, embora o corante eosina tenha sido considerado o método mais apropriado para o uso com os materiais selecionados; o teste com radiocálcio foi associado com vários problemas e o seu uso não foi justificado; o uso do nitrato de prata com restauração de amálgama é inapropriado e os testes deste traçador com restaurações de cimento de ionômero de vidro devem ser tratados com cuidado; a gelatina ácida falhou em demonstrar infiltração marginal; e sugeriram que os resultados dos estudos "in vitro" deveriam ser comparados com um longo acompanhamento "in vivo".

DAVIDSON; ABDALLA ${ }^{53}$, em 1993, analisaram a estabilidade da adaptação gengival de restaurações classe $V$ de resina composta antes $e$ depois dos espécimes sofrerem estresse térmico e de carregamento. Utilizaram 96 molares humanos extraídos, onde confeccionaram cavidades oclusoproximais, com as margens cervicais localizadas abaixo da junção amelodentinária e as margens em esmalte biseladas em $45^{\circ} \mathrm{com} 1 \mathrm{~mm}$ de largura. Os dentes foram então divididos em 6 grupos: Grupo1: as cavidades foram limpas com Tubulicid, as paredes dentinárias foram protegidas com Tubulitec liner, a seguir o esmalte foi condicionado com ácido fosfórico, lavado, seco e o adesivo 
Heliobond aplicado em todas as paredes da cavidade e em seguida foram restauradas com a resina composta Heliomolar em dois incrementos; Grupo 2: as cavidades foram limpas com spray de ar/água, secas e as paredes dentinárias protegidas com Vitrebond (cimento de ionômero de vidro) até próximo da margem gengival, a técnica restauradora foi a mesma utilizada no grupo 1; Grupo 3: as margens de esmalte foram condicionadas com ácido fosfórico, sobre as paredes dentinárias foi aplicado Scotchprep primer, e a resina composta utilizada para a restauração foi a P-50, em dois incrementos. Grupo 4: exatamente como o Grupo 3, mas utilizando o Vitrebond; Grupo 5: todo o preparo foi condicionado por ácido fosfórico, lavado e seco, uma camada de Clearfil Photobond foi aplicada em toda a cavidade e a restauração feita com Clearfil Photoposterior, em dois incrementos; Grupo 6: idem ao Grupo 5, mas utilizando também o Vitrebond. As restaurações foram polidas imediatamente após serem confeccionadas. Os dentes foram estocados em água a $37^{\circ} \mathrm{C}$ por 1 a 2 semanas. Depois deste período, 8 dentes de cada grupo sofreram ciclagem térmica entre $5^{\circ} \mathrm{C}$ e $55^{\circ} \mathrm{C}$ permanecendo 3 minutos em cada banho, até completar 500 ciclos. Estes mesmos dentes foram levados à máquina de testes para sofrerem carregamento oclusal. $O$ carregamento aplicado foi de forma intermitente e de $12,5 \mathrm{Kg}$, completando 52 ciclos por minuto, totalizando 400 ciclos. Este procedimento foi realizado com os espécimes imersos em solução de azul de metileno a $2 \%$. Os espécimes restantes foram pintados com esmalte e imersos na mesma solução corante por 24 horas. Terminados estes procedimentos os dentes foram seccionados ao meio e a infiltração marginal avaliada por meio de escores de 0 a 4 . $O$ efeito do carregamento na estrutura dentária e na restauração foi avaliada pelo SEM. A análise estatística dos resultados mostrou que não houve diferença significante na penetração do corante nas restaurações que utilizaram cimento de ionômero de vidro como proteção, quando sofreram carregamento oclusal ou não. Entretanto, as restaurações feitas com sistema adesivo somente, demonstraram um significante aumento na microinfiltração depois da ciclagem térmica e carregamento oclusal. Os autores concluíram que o cimento de ionômero de vidro utilizado pode proteger restaurações de resina composta classe II de deterioração marginal. 
STANINEC; KAWAKAMI ${ }^{184}$, em 1993, se propuseram a estudar comparativamente a efetividade de dois sistemas adesivos dentinários de baixa viscosidade que contêm éster fosfato baseados em 1) Bis-GMA/HEMA e 2) PMDM/NTG-GMA, e examinaram 0 efeito da baixa viscosidade destes sistemas. Os testes realizados foram: 1) cisalhamento e tração em vários intervalos de tempo depois de restaurados; e 2) microinfiltração por testes de penetração de corante. Utilizaram molares humanos. Para os testes de cisalhamento, o esmalte oclusal foi removido e a dentina ficou exposta, depois de preparada a área de união foi definida por uma matriz Mylar com $5 \mathrm{~mm}$ de diâmetro e um tubo de polietileno, a resina composta foi condensada em seu interior, proporcionando cilindros de $2 \mathrm{~mm}$ de altura. Estes espécimes foram divididos em 4 grupos de acordo com os materiais restauradores: -T-MMarathon-one; K-LVR-P- Clearfil photo posterior + resina de baixa viscosidade; K-P-Clearfil photo posterior; SB-P50-P50. Para os testes de tração, os dentes com a dentina oclusal exposta foram montados em um jig, a área de adesão foi delimitada com uma matriz Mylar de $5 \mathrm{~mm}$ de diâmetro, e uma cavidade biselada com $5 \mathrm{~mm}$ foi confeccionada sobre esta área. Nos testes de tração e cisalhamento foram utilizados 16 espécimes para cada grupo e foram determinados imediatamente após a fabricação. Os outros espécimes foram estocados em $100 \%$ de umidade em temperatura ambiente por 1 e 24 horas. Outros 16 espécimes para cada grupo foram estocados por 1, 3 e 6 meses antes dos testes de união. O teste de cisalhamento foi realizado com uma ponta em forma de faca movendo-se paralela à superfície testada, em uma máquina de teste à $0,5 \mathrm{~mm} /$ minuto. Para o teste de microinfiltração 40 molares humanos foram utilizados. Cavidades de classe $\mathrm{V}$ foram confeccionadas nas faces vestibular e lingual destes; a margem oclusal localizou-se em esmalte e a cervical em cemento. As cavidades foram divididas em 4 grupos de 20 dentes cada e restaurados com os mesmos materiais já citados. Depois de restaurados os dentes foram estocados em água destilada por 24 horas a seguir polidos com discos de Soflex. Em seguida foram termociclados por 1000 ciclos em banhos de $4^{\circ} \mathrm{C}$ e $60^{\circ} \mathrm{C}$, permanecendo 60 segundos em cada banho. Os dentes foram então cobertos com esmalte para unha, exceto a restauração e $0,5 \mathrm{~mm}$ ao seu redor em seguida imersos em solução de fucsina básica por 
24 horas a $37^{\circ} \mathrm{C}$. Depois de removidos da solução, foram lavados e seccionados no centro da restauração no sentido vestíbulo-lingual, as duas metades dos espécimes foram examinadas em um microscópio com $100 \mathrm{x}$ de aumento; os resultados foram expressos em $\mathrm{mm}$. Depois da análise dos resultados, os autores concluíram que: significantes mudanças na força de cisalhamento em relação ao tempo ocorreram entre os grupos T-M e SB-P50, mas não entre K-LVR-P e K-P. K-LVR-P e T-M, que tiveram menor infiltração marginal e a maior força de cisalhamento no teste imediato. A adição de resina de baixa viscosidade resultou em significante menor infiltração e maior força de cisalhamento no grupo K-LVR-P quando comparado ao grupo K-P. Nos testes de tração, mudanças com relação ao tempo entre cada grupo foram geralmente menores do que nos teste de cisalhamento. A quantidade de infiltração observada correlacionou com a força de cisalhamento.

BARNES et al. ${ }^{8}$, em 1993, se propuseram a estudar se existiam diferenças na microinfiltração que ocorre "in vivo" e a que ocorre "in vitro", em restaurações de resina composta de cavidades de classe $\mathrm{V}$ usando dois adesivos dentinários (Universal Bond 2 e Universal Bond 3). As cavidades foram preparadas em 24 pares de dentes nas superfícies vestibular e lingual. Um dente de cada par foi preparado e restaurado "in vivo" e o outro "in vitro". As amostras "in vivo" foram extraídas 6 semanas depois de restauradas. As amostras "in vitro" foram termocicladas por 540 ciclos entre $5^{\circ} \mathrm{C}$ e $55^{\circ} \mathrm{C}$, permanecendo 1 minuto em cada banho. Todos os dentes foram corados com nitrato de prata, divididos longitudinalmente e avaliados por critérios de escores de 0 a 4. Os autores não encontraram diferenças significantes na microinfiltração entre as restaurações que utilizaram os adesivos Universal Bond 2 e Universal Bond 3. Entretanto encontraram diferenças estatisticamente significantes, quando compararam "in vivo" e "in vitro", ocorreu uma maior microinfiltração nas restaurações "in vitro".

Em 1993, SWIFT; DENEHY; BECK $^{188}$, compararam várias concentrações de ácido fosfórico e o ácido maleico utilizado no Scotchbond Milti-Purpose como condicionadores de dentina. Utilizaram 15 molares 
humanos extraídos, a superfície proximal dos dentes foi desgastada com ponta diamantada para expor a dentina. Os dentes foram então montados em uma base de resina acrílica e divididos em 5 grupos de 10 espécimes cada e condicionados por 15 segundos com os seguintes agentes: Grupo 1: condicionador do Scothbond Multipurpose (ácido maleico a 10\%) e considerado o grupo controle; Grupo 2: Condicionador gel do Scotchbond (ácido fosfórico à 35\% com Sílica); Grupo 3: Uni-Etch (ácido fosfórico a 32\%); Grupo 4: All-Etch (ácido fosfórico a 10\%); Grupo 5:- Etch "N" Seal (ácido fosfórico à 25\% com cristais de oxalato de alumínio). O primer e o adesivo utilizado foi o do sistema do Scotchbond Multi-Purpose conforme instruções do fabricante. A resina composta utilizada foi a Z-100, que foi condensada dentro de um cilindro plástico de $2.9 \mathrm{~mm}$ de diâmetro e $3 \mathrm{~mm}$ de profundidade e fotopolimerizada por 60 segundos. Os moldes foram então removidos e os espécimes estocados em água destilada por 48 horas e depois termociclados 300 vezes em banhos de água de $5^{\circ} \mathrm{C}$ e $55^{\circ} \mathrm{C}$, por 30 segundos em cada temperatura, entre os banhos havia um intervalo de 10 segundos. Terminada a termociclagem os espécimes foram levados à máquina Instron em uma velocidade de $0,5 \mathrm{~cm} / \mathrm{min}$. Depois de fraturados os espécimes foram analisados com microscopia eletrônica (SEM). Os resultados foram expressos em MPa e foram os seguintes: Grupo 1: 17.3; Grupo 2: 17.2; Grupo 3: 15.2; Grupo 4: 13.6 e Grupo 5: 5.2. Os autores concluíram então que o condicionador recomendado pelo Scochbond Multipurpose (ácido maleico 10\%) obteve uma força de adesão semelhante ao ácido fosfórico nas concentrações de 10\%, 32\%, ou 35\%; e que o uso do condicionador do Scotchbond Multi-Purpose necessita de maiores investigações.

HALLER et al. $^{89}$, em 1993, investigaram o efeito de diferentes meios de estocagem na eficácia de cinco sistemas adesivos com diferentes mecanismos de adesão. A efetividade destes foi determinada pela capacidade de prevenir infiltração marginal. 125 terceiros molares humanos foram usados imediatamente após a extração (grupo controle) ou depois de um período de 3 a 4 semanas de estocagem em cloramina a $1 \%$, etanol a $70 \%$; formalina a $10 \%$; ou timol a $0,1 \%$. Cavidades de classe $\mathrm{V}$ com margem cervical em 
cemento ou dentina foram preparadas e restauradas com uma resina composta de microparticulas usando cinco adesivos dentinários diferentes. Depois da termociclagem, que consistiu de 1440 ciclos em banhos de $5^{\circ} \mathrm{C}$ e $55^{\circ} \mathrm{C}$, e do corante fucsina básica, a profundidade de penetração do corante nas margens gengivais foi determinada e classificados em uma escala de 0 a 4. Restaurações de classe $\mathrm{V}$ em dentes estocados em formalina mostraram significantemente menos microinfiltração (média de escores $=1,7$ ) do que as restaurações em dentes recentemente extraídos (grupo controle, média = 3,1). Os escores em dentes estocados em cloramina (média $=2,7$ ), etanol (média = 3,0 ) ou timol (média $=3,2$ ) não foram significantemente diferentes dos escores de microinfiltração do grupo controle. A melhora da eficácia "in vitro" dos adesivos dentinários quando usados em dentes extraídos estocados em formalina é provavelmente o resultado da união ao colágeno do formaldeído. Desde que uma alteração da dentina não reflita a condição do substrato "in vivo", dentes extraídos para avaliações "in vitro" de adesivos dentinários não deveriam ser estocados em formalina. Os dentes estocados em cloramina à $1 \%$ demonstraram resultados comparáveis aos dentes recentemente extraídos.

De acordo com os resultados destes trabalhos os autores concluíram que a estocagem dos dentes em solução de cloramina a $1 \%$ é recomendada para testes de laboratório para microinfiltração de adesivos dentinários.

Com o intuito de verificar a possibilidade de se utilizar o ácido fosfórico para condicionamento total, quando utilizado o sistema adesivo Scotchbond Multi-Uso, BECK; SWIFT; DENEHY ${ }^{11}$, em 1993, avaliaram a resistência ao cisalhamento desse adesivo, na dentina condicionada com ácido fosfórico a 35\%, 32\% e 10\% e com Etch' n' Seal (ácido fosfórico 35\% com oxalato de alumínio), e os compararam com o ácido maleico a 10\%. Utilizaram a dentina proximal de molares humanos extraídos e o tempo de condicionamento foi de 15 segundos. Os espécimes foram submetidos à ciclagem térmica em água com 300 ciclos, variando entre $5^{\circ} \mathrm{C}$ e $55^{\circ} \mathrm{C}$. A análise estatística mostrou que a medida dos valores da resistência de união do Etch' n'Seal, foi significantemente menor que os demais agentes, os quais obtiveram valores semelhantes entre si. A análise da microscópia eletrônica de varredura 
demonstrou que tanto o ácido maleico como o ácido fosfórico (10\%, 32\% e $35 \%$ ) removem completamente a "smear layer" e descalcifica a dentina subjacente, entretanto o Etch'n'Seal, promoveu a formação de um precipitado na superfície obliterando os túbulos dentinários. Concluíram que o uso do ácido maleico e fosfórico determina semelhante resistência adesiva quando usado o sistema adesivo Scotchbond Multi-Uso.

Em 1993, HASEGAWA; RETIEF ${ }^{95}$, avaliaram a microinfiltração quantitativa de cavidades de Classe $\mathrm{V}$ em cemento (dentina) reatauradas com seis sistemas adesivos dentinários, "in vitro". Noventa pré-molares extraídos foram utilizados, e os preparos foram confeccionados na raiz vestibular destes dentes. Os preparos foram restaurados com 1) sistema adesivo dentinário contendo $2 \%$ de HEMA e BISGMA e uma resina composta de micropartículas fotopolimerizáveis; 2) o mesmo material somente substituindo a base META/MMA e o monômero TBB pelo BISGMA; 3) um sistema adesivo dentinário contendo $35 \%$ de HEMA com a base META/MMA e catalisador TBB, e uma resina de micropartícula fotopolimerizável; 4) o mesmo material com uma resina composta híbrida experimental fotopolimerzável; 5) o mesmo sistema adesivo dentinário somente substituindo o gliceril metacrilato a $35 \%$ pelo HEMA a 35\% e usando uma resina composta de micropartículas; e 6) um sistema previamente descrito com uma substituição de 0,5 mol de EDTA por 10\% de ácido cítrico- 3\% de $\mathrm{FeCL}_{3} ; 15$ dentes foram restaurados com cada procedimento. As restaurações foram acabadas 15 minutos depois com broca carbide de 12 lâminas, os dentes foram estocados em solução salina a $37^{\circ} \mathrm{C}$ por 24 horas, polidos com Soflex e termociclados em solução de azul de metileno a $2 \%, 500$ vezes entre $50^{\circ} \mathrm{C}$ e $8^{\circ} \mathrm{C}$ permanecendo 15 segundos em cada banho. Microinfiltração quantitativa foi determinada por um método de espectrofotometria e os resultados expressos em $\mu \mathrm{g} /$ corante/restauração. Os dados foram analisados e os autores chegaram aos seguintes resultados: a microinfiltração quantitativa dos dentes restaurados com os sistemas adesivos contendo $35 \%$ de gliceril metacrilato foi significantemente reduzida, entretanto o mecanismo de união deste adesivo ainda não é conhecido. 
GRIEVE; SAUNDERS; ALANI" ${ }^{87}$, em 1993, comparam "in vitro" os efeitos de quatro adesivos dentinários na infiltração marginal de resina composta posterior depois de estocado por dois anos. Cimento de ionômero de vidro também foi incluído neste estudo. Utilizaram 484 pré-molares sem cáries, prepararam cavidades de Classe $\mathrm{V}$ na face vestibular, com dimensões padronizadas. Em metade dos dentes que foram restaurados com resina composta, o ângulo cavo-superficial foi determinado em aproximadamente $90^{\circ}$ e o restante biselados em $45^{\circ}$. A resina composta utilizada foi a Occlusin e os adesivos: Scotchbond; Experimental; Bonding agent; Topaz e Gluma. O cimento de ionômero de vidro, Chem fil II foi usado em cavidades sem bisel. Depois de restaurados os dentes foram estocados em água deionizada a $37^{\circ} \mathrm{C}$. Imediatamente antes do teste de infiltração os dentes foram termociclados a $5^{\circ} \mathrm{C}, 37^{\circ} \mathrm{C}, 55^{\circ} \mathrm{C}$ e $37^{\circ} \mathrm{C}$, por 10 segundos em cada temperatura, por 24 horas, somando 2110 ciclos. As restaurações foram testadas depois de 6 meses, 1 ano e 2 anos, usando uma técnica de isótopo radioativo e avaliados segundo uma escala de escores de 0 a 4 . Com base nos resultados concluíram que alguma infiltração ocorreu para todos os materiais em cada intervalo de tempo. As cavidades biseladas mostraram significantemente menos infiltração que as cavidades não biseladas. Entretanto, a diferença entre os vários sistemas adesivos foi pequena. As restaurações de ionômero de vidro mostraram significantemente menos infiltração que as de resina composta e sistema adesivo em cavidades sem bisel.

Com o propósito de estudar a permeabilidade dentinária dos agentes adesivos, PASHLEY et al. ${ }^{149}$, em 1993, observaram através do microscópio eletrônico de varredura (MEV), o efeito produzido pela aplicação do ácido fosfórico a 37\% por 30 segundos sobre a superfície de dentina oclusal humana, coberta ou não por "smear layer", deixando, ainda a mesma superfície, após condicionada e lavada, seca usando jatos de ar por 30 segundos ou visivelmente úmida. Para controle utilizaram metade da superfície dentinária de cada espécime, de ambos os grupos, a qual não foi descalcificada. As microfotografias mostraram que na superfície da dentina fraturada sem "smear layer", seca ou úmida, houve um aumento no diâmetro 
dos túbulos dentinários, pela perda da dentina peritubular e no número das porosidades na dentina inter e intratubular. Com maior aumento, constataram a presença de muitas fibras colágenas expostas. Porém observaram que a área descalcificada embaixo da superfície, era ainda mais porosa, já que no topo, as fibras colágenas se condensavam e colapsavam formando uma fina cobertura (similar a crosta) ainda maior nos espécimes que foram secos com ar. No caso do grupo onde a dentina estava coberta por "smear layer", as imagens demonstraram que após aplicação do ácido eram eliminados completamente aqueles "debris", inclusive a "smear layer", acompanhado de um aumento dos túbulos dentinários e do número de porosidades na superfície dentinária subjacente. No entanto, dentro deste grupo, os espécimes que foram secos com ar, apresentaram uma superfície com regiões alternadas porosas e não porosas. As fibras colágenas superfíciais apareciam mais condensadas e cobertas por uma camada amorfa de colágeno solto residual ("smear layer" de colágeno) proveniente da descalcificação da "smear layer" o que, segundo os autores, complicava a penetração da resina adesiva. Concluiram que o condicionamento ácido restringe o potencial de porosidades na dentina pela criação de uma fina camada de fibras colágenas condensadas na superfície e zona descalcificada que aumenta quando existe a "smear layer" de colágeno residual, diminuindo ainda o número de porosidades especialmente quando se utiliza ar para secar a dentina. Portanto, o substrato dentinário ideal para conseguir uma boa penetração da resina adesiva será aquela dentina descalcificada visivelmente úmida. Se a dentina desmineralizada se mantém úmida, as fibras colágenas não se condensam. As fibras colapsadas podem reexpandir-se com água e também com a aplicação de monômeros hidrofílicos como o HEMA.

Considerando a interface dente/restauração, DUKE $^{60}$, em 1993, constatou que o desenvolvimento tem ocorrido em vários sistemas adesivos dentinários com "primers" hidrofílicos, permitindo uma maior penetração de adesivo na superfície da dentina condicionada com ácidos, promovendo um aumento na resistência de união à contração de polimerização e mudanças térmicas. Dentro destes sistemas adesivos, o autor menciona o Scotchbond 
Multi-Uso (3M) que utiliza como condicionador o ácido maleico a $10 \%$ seguido de um "primer" hidrofílico (HEMA) e do adesivo, criando uma união mecânica pela formação da camada híbrida. Comenta que ainda existem controvérsias se deve-se ou não eliminar a "smear layer". Conclui que a microinfiltração pode ser reduzida significativamente usando um adesivo pré-polimerizável e a técnica incremental para condensar a resina composta.

ROULET $^{172}$, em 1994, fez uma análise do significado clínico dos estudos "in vitro" da integridade marginal. Relata que a integridade marginal das restaurações é um parâmetro importante, uma vez que a formação de espaço marginal está associado às cáries recorrentes e doença pulpar. Os testes "in vitro" são vistos com incertezas devido às interações e problemas de interpretação. Para a avaliação "in vitro" da qualidade das margens, as restaurações são realizadas em dentes extraídos sob condições clínicas simuladas, ou sob condições especiais especificamente adaptadas para o teste pretendido. Estas restaurações geralmente sofrem estresse térmico (termociclagem com 2000 ciclos de $5^{\circ}$ a $55^{\circ} \mathrm{C}$ ) ou mecânico ou ainda por um ataque ácido com gel acidulado. Os dados obtidos nestes testes são analisados estatisticamente por testes não paramétricos (MannWhitney, Wilcoxon, KrusKall-Wallis ou Nemenyi) que são os preferidos pela distribuição normal dos dados. Estes testes são baseados na penetração de corantes (por exemplo fucsina), íons (por exemplo nitrato de prata) ou isótopos radioativos (por exemplo $\mathrm{Ca}^{45}$ ) entre a interface da restauração e o dente. Estes métodos requerem a destruição das amostras por seccionamento, portanto estudos longitudinais não podem ser realizados. $O$ autor considera que as avaliações realizadas pela análise quantitativa das margens pelo microscópio eletrônico de varredura é mais precisa por ser baseada em réplicas. Quando a interpretação dos dados é através da qualidade marginal, os pesquisadores, segundo o autor, encontram problemas, pois esta depende do tamanho molecular (corante, isótopo, toxina, microorganismos), polaridade molecular, interação da superfície entre o corante e o material restaurador, capilaridade e o tempo. $\mathrm{O}$ método utilizado pelo pesquisador influenciará significantemente nos resultados. Depois de avaliar estes fatores o autor concluiu que os testes "in 
vitro" são essenciais para comparação com os achados clínicos. Entretanto, sugere aos pesquisadores entenderem as limitações destes testes e aceitar que podem errar no julgamento de um bom material e avaliar positivamente materiais ruins.

PRATI et al. ${ }^{155}$, em 1994, avaliaram longitudinalmente a microinfiltração de vários sistemas de resina composta que têm se mostrado superiores em relação à microinfiltração em restaurações extensas de cavidades de classe II (MOD), em vários períodos da inserção, por 10 meses e seguidos de ciclagem térmicas e carregamento oclusal. Compararam também a microinfiltração determinada por pressão de fluidos com a microinfiltração determinada pela penetração de corante. Três diferentes combinações de adesivos dentinários e resina composta posterior foram utilizadas. Vitrebond/Scotchbond 2/P50; Triptron/Occlusin e Clearfil Photo bond/Clearfil Photo posterior. Os preparos foram realizados em $3^{\text {os }}$ molares recentemente extraídos; todas as margens foram terminadas $2 \mathrm{~mm}$ abaixo da junção cemento-esmalte. Um fluído sobre pressão foi conectado com a câmara pulpar de cada dente para avaliar a permeabilidade e infiltração marginal das restaurações de $0.069 \mathrm{MPa}$. A microinfiltração foi testada depois da inserção das restaurações 2, 15, 45 e 150 minutos; 1, 2, 7 e 14 dias; 1, 2 e 3 meses; com 3 meses também foi realizada a ciclagem térmica que consistiu de 240 ciclos em temperatura de $4^{\circ} \mathrm{C}$ e $55^{\circ} \mathrm{C}$ por 30 segundos em cada banho. Depois da ciclagem os dentes foram novamente levados ao aparelho para medir a permeabilidade. Passados 7 meses a microinfiltração foi novamente medida e a seguir os espécimes foram submetidos a carregamento oclusal cíclico de 17 $\mathrm{Kg}$ de 10 em 10 segundos. Terminados estes procedimentos os espécimes foram expostos à solução de nitrato de prata para medir a microinfiltração pela penetração do corante. Imediatamente depois da inserção das restaurações, todos os materiais mostraram uma maior microinfiltração do que 1 e 2 dias. Depois de 4 e 8 semanas, todos as restaurações exibiram um aumento na permeabilidade sugerindo que a expansão higroscópica não foi suficiente para suprir a degradação hidrolítica das restaurações. Segundo os autores, nem a termociclagem nem o stresse oclusal aumentou a microinfiltração das 
restaurações, e que ambos os métodos para detectar infiltração possuem vantagens e desvantagens e podem ser usados para avaliar infiltração.

Em 1994, BARKMEIER; ERICKSON ${ }^{7}$, avaliaram a resistência ao cisalhamento da união de uma resina composta (P50) ao esmalte e à dentina utilizando o sistema adesivo Scotchbond Multi-Purpose. As forças adesivas foram testadas em esmalte e dentina humanos e bovinos. Para os dentes humanos foram utilizados 50 dentes, que depois de serem preparadas as superfícies vestibulares foram divididos em 5 grupos de 10 dentes cada e receberam tratamentos diferentes em esmalte. A união à dentina também foi testada em um grupo com 10 espécimes. (Tabela 1).

TABELA 1: Tratamentos do esmalte e dentina humanos.

\begin{tabular}{c|c|c|c|c}
\hline Grupos & Condicionador & Primer & Adesivo & $\begin{array}{c}\text { Mat. } \\
\text { Restaurador }\end{array}$ \\
\hline Esmalte & & & & \\
\hline $\mathbf{1}$ & $\mathrm{H}_{3} \mathrm{PO}_{4} 37 \%$ & - & Enamel Bond & $\mathrm{P} 50$ \\
$\mathbf{2}$ & $\mathrm{H}_{3} \mathrm{PO}_{4} 37 \%$ & - & Adesivo SBMP & $\mathrm{P} 50$ \\
$\mathbf{3}$ & $\mathrm{H}_{3} \mathrm{PO}_{4} 37 \%$ & SBMP Primer & Adesivo SBMP & $\mathrm{P} 50$ \\
$\mathbf{4}$ & Àc. maleico 10\% & - & Adesivo SBMP & $\mathrm{P} 50$ \\
$\mathbf{5}$ & Àc. maleico 10\% & SBMP Primer & Adesivo SBMP & $\mathrm{P} 50$ \\
\hline Dentina & & & & \\
\hline $\mathbf{6}$ & Àc. maleico 10\% & SBMP Primer & Adesivo SBMP & P50 \\
\hline
\end{tabular}

$\mathrm{Na}$ avaliação do esmalte e dentina bovina também testaram o efeito da secagem extrema com ar do Primer e a secagem agressiva do Adesivo para diminuir sua espessura. Utilizaram 50 incisivos bovinos. Depois de preparados para o teste foram divididos em dois grupos para esmalte e três para dentina. Cada grupo recebeu um tratamento diferente (Tabela 2). 
TABELA 2: Tratamento do esmalte e dentina bovino.

\begin{tabular}{|c|c|c|c|c|}
\hline Grupo & Condicionador & Primer & Adesivo & $\begin{array}{c}\text { Mat. } \\
\text { Restaurador }\end{array}$ \\
\hline \multicolumn{5}{|l|}{ Esmalte } \\
\hline 7 & $\mathrm{H}_{3} \mathrm{PO}_{4} 37 \%$ & - & SBMP & P50 \\
\hline 8 & Àc. maleico & - & SBMP & P50 \\
\hline \multicolumn{5}{|l|}{ Dentina } \\
\hline 9 & Àc. maleico & Primer SBMP & SBMP & P50 \\
\hline 10 & Àc. maleico & $\begin{array}{c}\text { Primer SBMP } \\
\text { (secagem extrema) }\end{array}$ & SBMP & P50 \\
\hline 11 & Àc. Maleico & Primer SBMP & $\begin{array}{l}\text { SBMP(afinamento } \\
\text { agressivo) }\end{array}$ & P50 \\
\hline
\end{tabular}

Depois de preparados os espécimes foram estocados em água destilada a $37^{\circ} \mathrm{C}$ por 24 horas e a seguir levados à máquina de ensaio Instron a uma velocidade de $5 \mathrm{~mm} /$ minutos. A força foi aplicada paralela e exatamente na área de união. Os resultados foram calculados em MPa e a área de união depois de fraturada, observada em um microscópio para detectar o tipo de falha. Os autores obtiveram os seguintes resultados: a mais alta resistência ao cisalhamento com relação ao esmalte foi encontrado no grupo 4 (38.3 \pm 80 $\mathrm{MPa})$ e no grupo $2(38.0 \pm 65 \mathrm{MPa})$. Não houve diferença significante na resistência ao cisalhamento entre os grupos 1, 2, 3 e 4, e houve uma diferença significante entre os grupos 4 e 5 e entre os grupos 2 e 5 . Não encontraram diferenças significantes também entre os grupos 1, 3 e 5. Com relação ao tipo de fratura os espécimes do grupo 2 apresentaram um grande número de falhas coesivas (50\%). Nos grupos 3 e 4, 30\% das falhas foram coesivas. Os grupos 1 e 5 apresentaram o menor número de falhas coesivas (10\%). O grupo 6 que avaliou a resistência ao cisalhamento em dentina, apresentou resultado semelhante $(25.5 \pm 7.5 \mathrm{MPa})$ ao grupo 5 onde o sistema adesivo foi utilizado seguindo instruções do fabricante. Quanto ao tipo de fratura, $40 \%$ dos espécimes falharam coesivamente. Nos grupos onde foram utilizados os dentes bovinos, a resistência ao cisalhamento no esmalte foi idêntica para os dois grupos condicionados com ácido fosfórico (grupo 7: $25.6 \pm 5.4 \mathrm{MPa}$ ) ou ácido maleico (grupo 8: $24.8 \pm 4.1 \mathrm{MPa}$ ). Não houve diferença estatística entre 
estes grupos. Encontraram uma alta resistência adesiva na dentina bovina do grupo $9(23.4 \pm 4.9 \mathrm{MPa})$. No grupo 10 encontraram um leve declínio na força

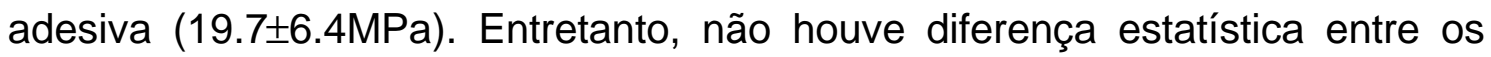
grupos 9 e 10. O grupo 11 apresentou uma força adesiva bem mais baixa (10.1 $\pm 6.6 \mathrm{MPa}$ ) e significantemente mais baixa que os grupos 9 ou 10. O tipo de fratura observado nos grupos 9 e 10 foi essencialmente coesiva (60\%). Analisando os resultados obtidos, os autores chegaram a algumas conclusões:1) os resultados sugerem que o condicionamento do esmalte com ácido maleico a 10\% e ácido fosfórico a 37\% promovem resistências adesivas iguais; 2) o uso do primer do SBMP no esmalte humano condicionado com ácido maleico a $10 \%$ ou ácido fosfórico a $37 \%$ reduziu a resistência de união; 3) a resistência de união do esmalte bovino foi aproximadamente $35 \%$ mais baixa que ao esmalte humano; 4) a resistência de união da dentina bovina foi similar à encontrada na dentina humana quando o sistema adesivo foi utilizado seguindo as instruções do fabricante; 5) a redução da união à dentina encontrada com a secagem agressiva com ar do adesivo, aconteceu provavelmente devido à polimerização inadequada do adesivo por causa da inibição pelo oxigênio.

CHAN; GLYN JONES ${ }^{39}$, em 1994 determinaram a significância da ciclagem térmica na microinfiltração do corante eosina associado com uma variedade de materiais restauradores, localizados inteiramente em superfície radicular. 20 pré-molares foram utilizados, preparos cavitários de classe $\mathrm{V}$ foram preparados nas superfícies vestibular, lingual, mesial e distal de cada dente. As quatro cavidades de cada espécime foram proporcionalmente restauradas com um material restaurador diferente. Material 1: amálgama ANA 2000 foi condensado dentro da cavidade; Material 2:- um cimento de ionômero de vidro- Ketac-Fil; Material 3: resina composta hibrida - Opalux; Material 4: resina composta de micropartículas - Pekalux. Todos os materiais foram utilizados de acordo com as instruções do fabricante. Imediatamente depois da restaurações, todos os espécimes foram estocados em uma solução salina. As restaurações de resina e ionômero de vidro foram polidas após 24 horas e foram arbitrariamente divididas em 2 grupos. O grupo 1 foi submetido a 150 
ciclos de $45^{\circ} \mathrm{C}$ ( 1 minuto); $37^{\circ} \mathrm{C}$ (4 minutos), $15^{\circ} \mathrm{C}$ ( 1 minuto), $37^{\circ} \mathrm{C}$ (4 minutos). O grupo 2 não foi submetido a estresse térmico, foi mantido em temperatura ambiente por uma semana em solução salina. Antes de serem imersos no corante os ápices selados com cera e duas camadas de esmalte para unha foram aplicado sobre todo o dente, exceto $1 \mathrm{~mm}$ ao redor da restauração. Os dentes foram imersos em corante eosina a 5\%, com pH 7.4, por 1 hora em temperatura ambiente. Depois de removidas do corante, as raízes foram seccionadas transversalmente, separando todas as restaurações. As restaurações foram seccionadas ao meio e avaliadas utilizando um estéreo microscópio com 2 vezes de aumento e classificadas seguindo sistema de escores de 0 a 4 . As duas paredes cavitárias foram avaliadas e consideradas, e a de maior escore é que foi levada para a análise. O mesmo avaliador leu os espécimes em 3 ocasiões diferentes, quando não ocorreu concordância entre os escores, o mais freqüente foi considerado, ou então a média deles. Analisando os resultados obtidos, os autores concluíram que todos os materiais restauradores testados demonstraram infiltração; o corante eosina teve capacidade para descriminar o comportamento da microinfiltração dos quatro materiais, mais efetivamente quando o teste foi realizado em temperatura constante; a ordem da microinfiltração associado com os quatro materiais variou de acordo com a temperatura adotada durante o teste; o grupo 1 (com ciclagem térmica) exibiu diferenças na performance da microinfiltração para os quatro materiais, mas nenhuma destas diferenças foi estatisticamente significante a nível de 0,05; o grupo 2 (não ciclado) demonstrou que a microinfiltração com o amálgama foi significantemente maior do que a do Opalux e Pekalux, e o Ketac-Fil mostrou significantemente mais infiltração que o Pekalux; a comparação entre os grupos 1 e 2 não mostrou diferenças estatísticas para cada material restaurador; e afirmaram que os resultados dos testes de microinfiltração "in vitro" deveriam ser interpretados com cautela com menores variações em condições experimentais, pois podem afetar significantemente os achados.

FUTATSUKI; NAKATA ${ }^{73}$, em 1994, investigaram "in vitro", a infiltração marginal de restauração de classe II de resina composta com 
estresse térmico nas margens cervical proximal vestíbulo-lingual e mésio-distal de pré-molares extraídos. Os materiais utilizados foram: 1) Occlusin com Bonding Agent; 2) Palfique Light-S com Light Bond; 3) P-50 com Dentin Primer e Scotchbond 2, e 4) P-50 vitrabond e Scothbond 2. Estes grupos foram representativos de um (1) agente convencional; (2) agente adesivo hidrofílico; (3) primer dentinário ou agente condicionante com um agente adesivo hidrofílico, e (4) cimento de ionômero de vidro usado no térmico do Sanduich, cada grupo foi formado por 10 dentes. A infiltração marginal foi avaliada pela penetração de solução de fucsina básica. Os resultados mostraram que o selamento da margem cervical foi significantemente melhor com o uso de adesivos dentinários do que quando comparados com um agente adesivo convencional (esmalte). A margem proximal geralmente apresenta menor efetividade de selamento do que a oclusal (vestíbulo-lingual e mésio-distal). Em adição, as margem mésio-distal mostraram um resultado mais favorável do que as vestíbulo-lingual, estas diferenças podem ser devido à eficácia do biselamento ao longo do ângulo cavo-superficial oclusal, a diferente espessura do esmalte cavitário, e a ordem da exposição da luz. Observaram também que o cimento de ionômero de vidro previne a penetração do corante na dentina, na técnica do sanduich, entretanto ocorreu infiltração marginal no esmalte deste grupo.

Analisando os adesivos com relação a prevenção da infiltração marginal, $\mathbf{R E T I E F}^{163}$, em 1994, por meio de uma revisão, relatou que todas as resinas compostas contraem durante a polimerização, resultando no desenvolvimento de tensão e/ou estresse na interface dente/restauração. A maior parte do estresse de contração ocorre nos primeiros 15 minutos depois da iniciação da polimerização mas com as resinas ativadas pela luz ela ocorre segundos após a irradiação. A tensão de estresse pode romper a união adesiva do sistema restaurador das paredes cavitárias resultando em microinfiltração na interface dente/restauração. As propriedades das resinas que incluem contração de polimerização durante o endurecimento, diferenças no coeficiente de expansão térmico dos dentes e restauração, e sorpção de água da restauração exposta ao ambiente oral, ocupam um importante papel 
na determinação das dimensões do microespaço marginal e daí a microinfiltração. A microinfiltração na interface esmalte/restauração tem sido eliminada pela técnica do condicionamento ácido. Entretanto, a microinfiltração na interface dentina/restauração, é muito mais difícil de ser eliminada. Nenhum dos sistemas adesivos restauradores elimina a microinfiltração da margem gengival das restaurações que se estendem ou são localizadas abaixo da junção cemento/esmalte. Segundo o autor, a microinfiltração é reduzida pelo uso da técnica incremental de restauração mas é aumentada quando o dente restaurado é submetido a estresse mastigatório ou carregamento oclusal. Nenhum dos sistemas adesivos previne o desenvolvimento de microespaços marginais na interface dentina/restauração quando avaliados 10 minutos depois de colocados na cavidade, mas a expansão higroscópica resultante da imersão em água ou solução salina resulta em uma significante redução das dimensões dos microespaços marginais. Um aumento nas margens cavosuperficiais por meio do bisel reduz as dimensões dos microespaços marginais mas não é dependente da profundidade da cavidade. A proporção do volume da cavidade para a área das paredes cavitárias e o volume da restauração têm uma influência significante nas dimensões do microespaço marginal. A utilização de uma técnica restauradora incremental e o atraso no acabamento e polimento da restauração reduzem significantemente as dimensões dos "gaps" marginais.

MIRANDA JÚNIOR ${ }^{126}$, em 1994, verificou, "in vitro", a infiltração nas margens (esmalte e dentina) das caixas proximais de pré-molares humanos extraídos restaurados com diferentes adesivos universais e resinas compostas. Utilizou resinas compostas associadas com três sistemas adesivos (All Bond 2, Scotchbond Multi-Uso e Optibond), aplicados sobre a superfície dentinária úmida ou seca. Após restaurados, os dentes foram armazenados em água a $37^{\circ} \mathrm{C}$ por uma semana, sendo que alguns grupos sofreram novo condicionamento ácido com aplicação de uma resina fluída (Fortify) na interface dente/restauração. Em seguida, foram realizadas a ciclagem térmica e a mecânica e a imersão em solução de nitrato de prata a 50\%. Três avaliadores estabeleceram o grau de infiltração (0-4). Quando a superfície 
dentinária ficou visivelmente úmida, houve uma diminuição no grau de microinfiltração para todos os adesivos.

Em 1994, GALE; DARVELL; CHEUNG $^{77}$, se propuseram a reconstituir com alta resolução, com computador um modelo tridimensional do padrão de infiltração do traçador, usando restauração de resina composta em dentina. Os testes de penetração de corante são muito comumente usados para detectar a ausência de um selamento da interface dente/restauração. A retenção de ar no "gap" marginal, permeabilidade dos traçadores durante o processo, e a falha de somente algumas poucas secções para permitir a interpretação do padrão, limitam estes testes pela baixa reprodutibilidade e precisão. Cavidades cilíndricas de Classe $\mathrm{V}$ em dentina foram confeccionadas na face vestibular e restauradas com resina. Foram termocicladas por 1000 ciclos, entre $8^{\circ} \mathrm{C}$ e $55^{\circ} \mathrm{C}$, permanecendo 30 segundos em cada banho, e então coradas com prata usando inicialmente vácuo $(100 \mathrm{mmHg})$. Cada restauração foi desgastada, produzindo 30 superfícies de aproximadamente 0,15 mm. As imagens das superfícies foram capturadas, e agrupadas por um programa de computador que analisa imagens e dá o padrão de penetração do corante tridimensionalmente. O máximo de profundidade de penetração do traçador abaixo da superfície foram $3 \mathrm{~mm}, 2.09 \mathrm{~mm}, 3.16 \mathrm{~mm}$ e $2.29 \mathrm{~mm}$ para os quatro espécimes. Projeções dos modelos foram vistas por várias direções com secções em várias localizações. Segundo os autores este método permite a criação de uma alta resolução tridimensional do padrão de penetração do traçador.

WATANABE; NAKABAYASHI ${ }^{200}$, em 1994, descreveram os métodos "in vitro" utilizados para medir adesão dentinária, considerando a eficiência, vantagens e desvantagens dos mesmos. O substrato dentinário, as condições de armazenagem, assim como os métodos utilizados para análise de microscopia eletrônica de varredura para testar resistência de união e microinfiltração são alguns dos fatores que podem influir quando se examina a união à superfície dentinária em laboratório. Explicaram que a ciclagem térmica permite estudar o efeito da diferença entre os coeficientes de expansão térmica 
dos tecidos dentinários e o material restaurador sobre a microinfiltração e a estabilidade adesiva, sendo o ideal, a utilização de temperaturas entre $5^{\circ} \mathrm{C}$ e $60^{\circ} \mathrm{C}$ e 15 segundos em cada banho porque simula de maneira mais próxima as condições "in vivo". Concluíram que ainda estão investigando condições experimentais padronizadas "in vitro" que possam simular as condições " in vivo"

BARREIROS; ARAÚJO; NAGEM FILHO ${ }^{9}$, em 1994 avaliaram a adaptação marginal das resinas compostas Herculite XRV e Z100 em cavidades padronizadas em dentina de molares humanos extraídos. Para isto, consideraram a eficiência de quatro sistemas adesivos diferentes (Scothbond Multi-Purpose, All Bond 2, Optibond, Prisma Universal Bond 3) na prevenção da formação das fendas marginais, assim como a influência do adiamento, por períodos de 10 minutos, 7 dias e 21 dias, da realização do acabamento e polimento das restaurações, no posterior fechamento dessas fendas marginais. Os adesivos que apresentaram melhor comportamento foram Optibond, Prisma Universal Bond 3 e o All Bond 2, porém, nenhum demonstrou ser eficiente no fechamento da fenda marginal da interface dentina/resina composta. Dos resultados obtidos, pode-se concluir que o acabamento das restaurações de resina composta é adequado se realizado 21 dias após, ou mais, para que através da expansão higroscópica das resinas ocorra o fechamento das fendas marginais, evitando a introdução de detritos e material de polimento que prejudique a restauração.

Com o objetivo de examinar a dentina condicionada e a estrutura da camada híbrida por meio de um microscópio eletrônico de varredura, TITLEY et al. ${ }^{194}$, em 1995, utilizaram terceiros molares superiores e inferiores recém extraídos, e incisivos bovinos extraídos. Depois de exposta a dentina destes dentes por meio de desgaste, foram divididos em quatro grupos de dentes humanos e quatro grupos de dentes bovinos para examinar o efeito dos agentes condicionadores e a infiltração dos adesivos. Grupos de oito dentes bovinos por sistema de resina foram preparados e usados no teste de cisalhamento. Para examinar o efeito do condicionamento, as dentinas bovina 
e humana foram tratadas com os seguintes materiais: a- ácido fosfórico gel a 35\% por 60 segundos; b- ácido fosfórico gel a 32\% por 15 segundos; c- ácido fosfórico gel a 10\% por 15 segundos; d- ácido maleico gel 10\% por 15 segundos; e- solução aquosa de ácido maleico a 25\% por 45 segundos; e fScotchbond 2 (contém ácido maleico a 2.5\% e HEMA). Todos os materiais foram utilizados seguindo instruções do fabricante. Dois espécimes de cada grupo foram secos com ar e deixados secar por duas horas com ar. Os outros dois espécimes remanescentes foram colocados em água antes do ponto crítico de secagem. Em um experimento subseqüente, quatro dentes humanos e quatro bovinos foram expostos ao ácido maleico gel 10\% por 15 segundos, lavados por 30 segundos, imersos em uma solução de etanol e HEMA por 30 segundos, e então lavados por mais 30 segundos. Para examinar a penetração do adesivo, duas camadas de SBMP foram aplicadas de acordo com instruções do fabricante. Dois espécimes foram deixados secar com ar e outros dois foram imersos em água como descrito previamente. Para os testes de cisalhamento, grupos de oito dentes bovinos foram usados para cada material citado a seguir: o preparo da superfície da dentina foi de acordo com instruções do fabricante e os materiais All/Bond 2, Scotchbond 2, Scotchbond Multipurpose, e Prisma Universal Bond 3. As resinas utilizadas foram Silux Plus e Z100. Os espécimes foram então estocados em água destilada a $37^{\circ} \mathrm{C}$ por um período de 1 dia, 7 dias ou 180 dias, depois de cada período, os dentes foram testados. Os dentes foram analisados em SEM. Esta análise mostrou que a aplicação de várias concentrações de ácidos na superfície da dentina removeram a "smear layer" e produziram vários graus de desmineralização na dentina intertubular e intratubular. O exame dos espécimes naturalmente secos tratados com ácido fosfórico e ácido maleico demostrou uma desmineralização da camada de colágeno colapsada, com isto produzindo uma superfície densa com nenhuma porosidade entre as fibras colágenas. Com base nos resultados os autores concluíram que o excesso de dessecação da dentina condicionada por ar ou por prolongado período de secagem natural causa um colapso do colágeno da dentina inter e intratubular, a qual resulta em uma aparente redução na porosidade da superfície. Os resultados também sugerem que o grau de colapso existente na zona de interdifusão, pode atuar como um 
impedimento da difusão da resina, independente da molhabilidade que 0 monômero hidrofílico confira ao colágeno. Essas observações indicam que com os sistemas resinosos examinados por este trabalho, uma interpenetração micromecânica de união é estabelecida entre o adesivo e o colágeno da zona de dentina desmineralizada. Embora múltiplas aplicações do primer pareçam aumentar a força de união, encontraram pequenas evidências que sugerem que a molhabilidade do colágeno é aumentada por este processo, desde que não se tenham observado evidências de aumento de penetração do adesivo apesar de um aumento significante na força de união. Como resultado destes achados, os autores questionaram se um extenso grau de desmineralização produzido pela concentração dos ácidos comerciais seja necessário, particularmente porque nenhum sistema adesivo testado infiltrou completamente a zona desmineralizada.

TITLEY et al. ${ }^{193}$, em 1995, examinaram "in vitro" a ultra estrutura e a composição dos "tags" de resina em dentina, usando o microscópio eletrônico de varredura e um corante vital. Utilizaram terceiros molares humanos extraídos e incisivos bovinos extraídos. A superfície dentinária dos dentes foi exposta para a realização dos testes. Para o tratamento da superfície dentinária utilizaram soluções aquosas de ácido maleico em várias concentrações: 10, 5, 2.5, 1 e 0,5\% e ácido fosfórico em concentrações de 37, 10, 5 e 1\%. Cada concentração do ácido foi aplicado em grupos de 13 dentes bovinos, 10 dos quais foram embebidos parcialmente em resina deixando a superfície condicionada livre, por 15 segundos e lavados por mais 30 segundos. A superfície foi levemente seca, sem provocar ressecamento na dentina e duas camadas de primer do SBMP foram aplicadas de acordo com as instruções do fabricante. Uma fina camada do adesivo do SBMP foi aplicada sobre esta área e a resina Z100 foi condensada por meio de uma matriz cilíndrica. Os dentes restaurados que foram embebidos em cilindros de resina foram estocados em água a $37^{\circ} \mathrm{C}$ por 24 horas antes do teste de cisalhamento. Os três dentes bovinos e os três terceiros molares humanos de cada grupo que não foram embebidos nos cilindros de resina foram tratados e restaurados como nos grupos anteriores. Estes três dentes foram preparados para ser 
examinados pelo SEM. Para o teste de cisalhamento, os dentes foram acoplados em uma Máquina Universal de testes, a ponta do teste foi colocada em contato com a interface dente/resina e a velocidade utilizada foi de $0,5 \mathrm{~cm} /$ minuto e a célula de carga de $50 \mathrm{Kg}$. Depois de avaliados os resultados, os autores concluíram que os "tags" de resina mostraram resina e glicosaminoglicans revestindo os túbulos dentinários. A análise no SEM sugeriu três mecanismos de formação de "tags" de resina, dois dos quais provavelmente se encontrem "in vivo".

MIEARSS JR.; CHARLTON; HERMESCH ${ }^{124}$, em 1995, avaliaram os efeitos da umidade da dentina e dois tempos diferentes de estocagem no cisalhamento, na união entre resina composta e dentina tratada com Scotchbond Multi-Purpose. A superfície de 60 molares humanos extraídos foi reduzida promovendo um "flat" na superfície dentinária, e então foram proporcionalmente divididos em quatro grupos de 15 espécimes cada. Os dentes foram condicionados, lavados, e então ou deixados com a superfície visivelmente úmida ou seca com ar. O primer e adesivo foram aplicados de acordo com as instruções do fabricante e os cilindros de resina composta foram unidos ao dente. Dois dos grupos (um úmido, um seco) foram estocados por 24 horas em água destilada a $37^{\circ} \mathrm{C}$ enquanto os outros dois grupos foram estocados por 90 dias em água destilada à $37^{\circ} \mathrm{C}$. Terminados os períodos de estocagem, os espécimes foram submetidos a um carregamento a $0,5 \mathrm{~mm} / \mathrm{min}$. Os valores médios da força de união e o desvio padrão foram medidos em MPa: dentina seca a 24 horas:-13.30 \pm 5.1 , dentina a 90 dias $13.07 \pm 3.8$, dentina úmida a 24 horas:-13.64 \pm 4.9 ; dentina à 90 dias:-15.58 \pm 5.3 . Não foram encontradas diferenças estatisticamente significantes para a união entre dentina úmida e seca ou diferentes tempos de estocagem.

TAY et al. ${ }^{190}$, em 1995, comparam dois métodos de avaliação de microinfiltração ao longo da interface dente/restauração. Um utilizado por eles em seus laboratórios que utiliza estereomicrocoscópio para a leitura do padrão de infiltração ao longo da interface dente/restauração e comparam a extensão da penetração de prata ao longo desta interface antes e depois da ácido 
desmineralização. Cavidades cilíndricas com diâmetro aproximado de $4 \mathrm{~mm}$ foram confeccionadas nas superfícies vestibulares e linguais de pré-molares e molares recentemente extraídos. As margens oclusais das cavidades foram biseladas em $45^{\circ} \mathrm{e}$ as gengivais não. Avaliaram diferentes materiais restauradores, que foram utilizados de acordo com as instruções do fabricante. Depois de restaurados e polidos os dentes foram mantidos a $37^{\circ} \mathrm{C}$ por 7 dias. $\mathrm{A}$ seguir, termociclados em banhos de $5 \pm 2^{\circ} \mathrm{C}$ e $55^{\circ} \mathrm{C} \pm 2^{\circ} \mathrm{C}$, permanecendo 1 minuto em cada banho, num total de 300 ciclos. Terminada a ciclagem, os dentes tiveram seus apíces selados com Vitremer, cobertos com esmalte exceto $1 \mathrm{~mm}$ ao redor da restauração e então colocados em solução aquosa de nitrato de prato a $50 \%$ por 2 horas, no escuro. Decorrido este tempo foram lavados, imersos em solução fotoreveladora e expostos a luz fluorescente por 6 horas para a completa redução dos íons prata. Depois de removidos desta solução foram lavados por 2 horas e imersos em acetona por 5 minutos para dissolver a camada de esmalte de unha. Os espécimes foram então descalcificados por imersão em solução de Kristensen's, trocado diariamente para facilitar o processo. Radiografias dos espécimes foram feitas para determinar o final completo da descalcificação. Os espécimes sofreram desidratação pelo etanol a 70\%, 80\% e 95\%, para prevenir retenção de áreas de capacidades que poderiam impedir a visualização da microinfiltração dos espécimes. Os espécimes depois de completamente desmineralizados e desidratados foram imersos em metil salicilato até esta solução tornar-se ambar, tornando possível a observação em 3-D na cor preta ao longo da interface, examinados por um estereomicroscópio e classificados de acordo com critérios pré-estabelecidos. Na segunda parte deste estudo, 15 espécimes foram restaurados com diferentes materiais e submetidos à termociclagem e ao corante prata como o método já citado. Foram seccionados por um disco diamantado e a microinfiltração de cada secção fotografada e digitalizada para ser analisada pelo software da Macintosh-PC expressando a porcentagem do comprimento total da interface e as médias foram calculadas. Depois das fotografias os espécimes foram desmineralizados e as medidas repetidas. A análise estatística dos dados obtidos não mostrou diferenças estatísticas na 
microinfiltração dos métodos testados. Este estudo confirmou também que a microinfiltração não é uniforme ao longo das margens da restaurações.

O propósito do estudo de ROSSOMANDO; WENDT ${ }^{170}$, em 1995, foi avaliar o efeito de dois diferentes tempos de imersão dos espécimes durante a termociclagem na análise de infiltração de alguns materiais. Utilizaram para isto 90 restaurações diretas em terceiros molares extraídos, divididos em três grupos. Realizaram preparos de classe $\mathrm{V}$ com $2 \mathrm{~mm}$ de largura na junção cemento-esmalte e com $2 \mathrm{~mm}$ de profundidade. Uma das margens foi localizada em esmalte e outra em cemento. Os materiais utilizados foram: resinas Heliomolar, Syntac e $\mathrm{APH}$, e o amálgama de alto conteúdo de cobre da marca Tytin. As cavidades foram restauradas seguindo instruções dos fabricantes. Depois de restaurados, os dentes foram preparados com uma obturação retrógrada de amálgama e cobertos por duas camadas de esmalte para unha, com exceção de $1 \mathrm{~mm}$ ao redor das restaurações. As amostras nos dois grupos experimentais foram submetidas ao corante fucsina básica durante toda a termociclagem. A exposição ao corante no grupo controle foi equivalente ao total de exposição das amostras que foram termocicladas. Depois disto os dentes foram seccionados em dois cortes de $1 \mathrm{~mm}$ cada. Somente as margens em cemento foram avaliadas, porque no esmalte a infiltração mostrou-se mínima. Os dois lados de cada secção foram lidos por um estereomicroscópio. A média das quatro leituras obtida para cada amostra é que foi utilizada para se avaliar a microinfiltração. A análise da infiltração seguiu o critério de escores pré-estabelecidos de 0 a 3. Observaram que não houve diferenças significantes na microinfiltração dos materiais testados para os três grupos. Mas, com o aumento do tempo de imersão ocorreu maior infiltração em todos os grupos, embora não significante do ponto de vista estatístico. Portanto, com o aumento do tempo de imersão, consequentemente a duração do insulto térmico é maior, anula as propriedades isolantes dos materiais restauradores, e o potencial para microinfiltração aumenta. Entretanto, tempos mais longos de imersão não poderiam ser considerados clinicamente relevantes. 
Sabendo que a permeabilidade dentinária afeta a adesão, CAMPS et al. ${ }^{33}$, em 1995, compararam o efeito de diferentes concentrações do ácido maleico, e diferentes tempos de exposição na permeabilidade dentinária. 130 terceiros molares recentemente extraídos foram utilizados. Os dentes foram divididos em cinco grupos. No primeiro grupo, a "smear layer" não sofreu tratamento. Nos três outros grupos, soluções de ácido maleico a 0.10, 0.25 ou $0.5 \mathrm{M}$ foram aplicadas na dentina por 15, 30 ou 60 segundos. Nos outros grupos, o condicionador do sistema adesivo Scotchbond Multi-Purpose foi aplicado por 15, 30 ou 60 segundos. De posse da avaliação estatística dos resultados os autores observaram que com 60 segundos de exposição, o condicionador dentinário do Scotchbond Multi-Purpose ou a solução de $0.1 \mathrm{M}$ de ácido maleico foi tão efetivo no aumento da permeabilidade de dentinária quanto as soluções de $0.25 \mathrm{M}$ e $0.5 \mathrm{M}$. O máximo de permeabilidade foi conseguido com 15 segundos da solução de ácido maleico com $0.25 \mathrm{M}$ e $0.5 \mathrm{M}$, depois de 30 segundos com Scotchbond Multi-Purpose e depois de 60 segundos com solução de ácido maleico a $0,1 \mathrm{M}$. Durante os primeiros 30 segundos, a solução de ácido maleico a $0.1 \mathrm{M}$ não aumentou a permeabilidade dentinária e não removeu totalmente a smear layer. Ressaltaram ainda, que a recomendação do fabricante de utilizar o condicionador do Scotchbond MultiPurpose por 15 segundos, produz um condicionamento moderado da dentina, e aumenta a permeabilidade dentinária em $1 / 4$ do valor máximo obtido neste estudo.

DIETSCHI et al. ${ }^{57}$, em 1995, avaliaram a adaptação marginal e o selamento de restaurações de resina composta classe II direta e indireta (inlay), realizadas com Z100/Scotchbond MP ou Herculite/Optibond. Foram comparadas também com ou sem bases de cimento de ionômero de vidro convencional ou cimento de ionômero de vidro modificado por resina. Depois de restaurados os dentes foram estocados por 24 horas em solução salina a $37^{\circ} \mathrm{C}$ e em seguida submetidos a 5000 ciclos com banhos de $5^{\circ} \mathrm{C}$ e $55^{\circ} \mathrm{C}$, permanecendo 1 minuto em cada banho. A análise da infiltração foi realizada por um microscópio eletrônico de varredura e pela infiltração de corante. Nas condições em que foi realizado o trabalho, a técnica de inlay indireta provou 
superioridade sobre o método direto. A qualidade da margem dentinária das restaurações realizadas com Z100/Scotchbond MP mostraram-se levemente melhores. Tanto o cimento de ionômero de vidro convencional como o modificado por resina, quando utilizados como base, aumentaram a infiltração e pioraram a adaptação marginal. Concluíram também que a união com os adesivos modernos parece ser o mais eficiente caminho para elevar a qualidade marginal das restaurações diretas e indiretas.

ORTEGA; SOUZA JÚNIOR ${ }^{143}$, em 1995, avaliaram a resistência adesiva do sistema Scotchbond Multi Uso/Z-100, em esmalte, empregando ácido fosfórico nas concentrações de 37\%, 10\% e ácido maleico a 10\% como condicionadores. Observaram que não houve diferenças estatisticamente significantes na resistência ao cisalhamento entre os grupos onde o ácido fosfórico foi empregado. Entretanto, a utilização do ácido maleico a 10\%, levou a uma significante redução da resistência adesiva em relação aos grupos testados.

Considerando os princípios que regem e controlam as variáveis que geram os estresses desenvolvidos nas interfaces das restaurações de resina composta, CARVALHO et al. ${ }^{34}$, em 1996, por meio de uma revisão de literatura, descreveram os fatores que podem interferir na infiltração da resina adesiva no interior da camada desmineralizada, e a influência desta infiltração na adesão entre o material restaurador e a estrutura dentária. A contração de polimerização sofrida pela resina poderá criar estresses que rompem a união junto às paredes cavitárias e essa competição entre o estresse mecânico sofrido pela polimerização e a união dos adesivos às paredes cavitárias, consiste em uma das principais causadas das falhas marginais e subsequente microinfiltração nestas restaurações. Os autores explicaram os efeitos da "smear layer" e a desidratação da superfície dentária desmineralizada. Relataram que o grau de estresse desenvolvido poderá ser controlado pela extensão e configuração da cavidade (fator $\mathrm{C}$ ), pelo emprego da bases, tamanho, forma e posição dos incrementos do material. Deve ser considerada ainda a natureza química ou fotopolimerizável das resinas compostas, 
considerando que o tipo de polimerização influencia a capacidade de escoamento do material. As resinas fotopolimerizáveis apresentam polimerização rápida ou imediata, o que permite menor escoamento quando comparadas às resinas de ativação química, por não existir um tempo maior correspondente à fase gel. Teoricamente, quanto menor o escoamento, maior será o estresse gerado durante a contração de polimerização, fator que, pode ser decisivo para o sucesso da restauração. Como conclusão, os autores relatam que os estresses gerados nas resinas compostas e nos agentes de união são bem mais complexos sob condições clínicas. Os altos valores de estresses gerados pela contração de polimerização, resultantes de alguns estudos, cujas cavidades possuem configurações específicas, superaram a força adesiva da resina à dentina esclarecendo talvez o alto e freqüente índice de falhas e de formação de "gaps" observados em vários estudos utilizando sistemas adesivos. Por outro lado, existem vários fenômenos e procedimentos relacionados à configuração, ao emprego de resinas quimicamente ativadas de baixo módulo linear e tempo de sorpção de água, os quais, caso bem entendidos e aplicados, contribuem para reduzir a contração de polimerização, oferecendo às restaurações melhor qualidade e longetividade.

Em 1996, MILLER et al. ${ }^{125}$, avaliaram vários materiais restauradores na tentativa de determinar o ideal para ser usado como incremento gengival na caixa proximal de preparos cavitários classe II, para minimizar a microinfiltração, quando se utiliza matriz metálica. Utilizaram 60 dentes extraídos, nos quais preparos cavitários padronizados mésio-oclusal ou disto-oclusal foram realizados com as margens $1 \mathrm{~mm}$ abaixo da junção amelodentinária. Os preparos foram divididos ao acaso em 6 grupos de 10 dentes cada, diferindo de acordo com o material restaurador utilizado Grupo 1: foi restaurado com a resina composta Heliomolar em 3 incrementos; Grupo 2: o incremento gengival foi realizado com a resina quimicamente ativada Bisfil $2 \mathrm{~B}$, seguindo de dois incrementos de Heliomolar; Grupo 3: o incremento gengival foi realizado com o ionômero de vidro resinoso Vitremer, seguido de dois incrementos de Heliomolar; Grupo 4: foi restaurado com a resina composta Tetric em 3 incrementos; Grupo 5: Bisfil 2B no incremento gengival +2 
incrementos de Tetric; Grupo 6: Vitremer no incremento gengival + dois incrementos de Tetric. $O$ polimento das restaurações foi imediato e os espécimes foram estocados em água destilada à temperatura ambiente por aproximadamente 2 semanas e então a 3 intervalos de termociclagem de 100 vezes em banhos de $5^{\circ}$ e $55^{\circ} \mathrm{C}$ por 8 segundos cada, intercalados com duas seqüências de carregamento oclusal de 25.000 vezes com 7,26 Kg. Os dentes foram cobertos com esmalte para unha exceto $1 \mathrm{~mm}$ ao redor das margens da restauração e então imersos em solução de nitrato de prata a 50\% por 4 horas. Depois de devidamente preparadas as restaurações foram seccionadas no sentido mesio-distal em cinco partes, as quais foram avaliadas em um microscópio com 40 vezes de aumento. O método utilizado foi o de escores pré-estabelecido de 0 a 3 . O escore mais alto de cada espécime foi utilizado para análise. Depois de avaliados os resultados, os autores concluíram que os ionômeros resinosos podem ser um método prático para reduzir a microinfiltração, e que os materiais de baixa viscosidade e polimerização química (Bisfil 2B) têm menor probalidade de infiltração quando comparados aos de alta viscosidade e fotopolimerizáveis (Tetric e Heliomolar). E não ocorreram diferenças significantes na microinfiltração entre a resina hídrida (Heliomolar) e a de micropartícula (Tetric).

DÉJOU; SINDRES; CAMPS $^{56}$, em 1996, compararam e explicaram os métodos estatísticos empregados para avaliar "in vitro" a eficiência do selamento de sistemas adesivos. Utilizaram 206 pré-molares humanos extraídos e dividiram-nos proporcionalmente em 13 grupos. Realizaram preparos cavitários de classe $\mathrm{V}$ na junção amelo-cementário na face vestibular de cada dente. As margens oclusais dos preparos foram biselados, e então restaurados com 13 sistemas adesivos: (Scotchbond-SB1; Scotchbond 2-SB 2; Syntac; Scotchbond Multi-purpose - SBMP pela técnica seca e úmida; Gluma Bond; Gluma 2000; All Bond 2 -aplicado de quatro formas diferentes: Prisma Universal Bond 2- PUB 2; Prisma Universal Bond 3PUB3). As resinas compostas utilizadas para restauração foram as seguintes: Pekalux, Helioprogress; Silux; Silux Plus; Prisma Fil; Pekafill; Bis-fil e Z100. Depois de restaurados os dentes foram estocados em solução de saliva a $4^{\circ} \mathrm{C}$ 
por 24 horas, e finalmente polidos. Os dentes foram então termociclados 100 vezes, a temperatura de $5^{\circ} \mathrm{C}$ e $55^{\circ} \mathrm{C}$ com um tempo de imersão de 30 segundos em cada temperatura. Terminada a ciclagem, os dentes foram cobertos com esmalte para unha, exceto $0.5 \mathrm{~mm}$ ao redor das restaurações e imersos em solução de fucsina básica à $0,5 \%$ por 24 horas a $37^{\circ} \mathrm{C}$. A seguir, foram lavados, secos e embebidos em resina epóxica e seccionados no sentido vestíbulo-lingual em três secções. Criando seis interfaces que foram examinadas com 100 vezes de aumento por um microscópio. Para examinar as secções, cinco critérios foram utilizados: média de 6 dados de medida de penetração do corante em cada dente, mediana destes 6 dados, moda destes 6 dados, máxima penetração do corante para dente, e porcentagem de dente em cada grupo sem nenhuma penetração de corante nas seis interfaces. A distribuição normal de cada dado nos 13 grupos (primeira validade de critérios nos testes paramétricos) foi checado com o teste Kolmogorov-Smirnov. A igualdade de variâncias (segundo critério de validade dos testes paramétricos) foi então avaliada pelo teste de Cochran. Independente do critério de avaliação, a melhor classificação dos sistemas utilizados foi: Prisma Universal Bond 3, Gluma Bond, e All-Bond depois de condicionamento total e dentina úmida. Por outro lado, 3 sistemas restauradores foram classificados muito diferentes de acordo com o critério de avaliação:- Scotchbond Mult-purpose com dentina úmida, Scotchbond 2 e Syntac. O Scotchbond Multi-purpose úmido foi o melhor classificado quando o critério foi a média, mediana ou moda e uma pobre classificação quando o critério foi a penetração máxima de corante ou a porcentagem de dentes em cada grupo sem nenhuma penetração do corante. O mesmo acontecendo com Scotchbond 2 e Syntac que foram melhores classificados quando o critério foi a média, mediana ou moda. Avaliando os resultados obtidos os autores concluíram que: 1) os resultados poderiam ser considerados como testes comparativos do máximo de infiltração que pode ser teoricamente esperado "in vivo"; 2) os resultados dependem do formato experimental e particularmente dos materiais restauradores: há uma relação entre a classificação relativa dos sistemas adesivos e o volume de material restaurador 3 ) os resultados também dependem da seleção do critério de 
avaliação. O critério que utiliza o máximo de penetração do corante pareceu ser o melhor critério de avaliação.

A interface resina/dentina formada por dois adesivos, Optibond e Scotchbond Multipurpose, foi ultramorfologicamente examinada por um microscópio de transmissão por VAN MEERBEEK et al. ${ }^{197}$, em 1996. As informações ultraestruturais das secções não desmineralizadas e desmineralizadas foi correlacionada. Foi hipotetizado que a diferença na formulação química dos dois adesivos poderia resultar em uma diferente aparência morfológica da camada híbrida. O exame da ultraestrutura pelo TEM provou que cada um dos dois sistemas adesivos foi capaz de estabelecer uma união micromecânica entre dentina e resina com a formação de uma camada híbrida. O Optibond apresentou uma camada híbrida com uma ultraestrutura relativamente uniforme, e ácido resistente. Estes três parâmetros foram encontrados com mais variáveis na camada híbrida formada pelo SBMP. Uma característica do SBMP foi a identificação de uma fase amorfa depositada na superfície externa da camada híbrida. Ambos os adesivos testados utilizam o conceito do condicionamento total, suas formulações químicas específicas resultam em diferenças na ultraestrutura interfacial que provavelmente promovem diferentes mecanismos de interligação adesivas. Os autores relataram porém que a significância clínica destes achados morfológicos ainda era desconhecida.

CORREA $^{43}$, em 1996, avaliou a influência de diferentes formas de tratamento da umidade remanescente nos preparos cavitários após lavagem do condicionador ácido, na infiltração marginal de restaurações adesivas. Utilizou o sistema adesivo Scotchbond Multi Uso/ Z-100. Preparou cavidades M. O. D., em 50 pré-molares humanos extraídos, com ambas paredes gengivais localizadas $1 \mathrm{~mm}$ abaixo da junção cemento/esmalte. Dividiu os espécimes em 5 grupos de 10 dentes cada. Após lavar o condicinador àcido e previamente à aplicação do sistema adesivo, a umidade remanescente nas cavidades foi tratada de diferentes formas: G.A- aplicação de jatos de ar por 10 seg.; G.B(controle) aplicação de jatos de ar por 3 seg.; G.C- emprego de papel 
absorvente; G.D- aplicação de jatos de ar por 10 seg., seguido de reumedecimento e jatos de ar por 3 seg.; G.E- aplicação de jatos de ar por 10 seg., seguido de reumedecimento e emprego de papel absorvente. Em seguida seguiram-se os passos para a restauração. Concluídas as restaurações, os dentes foram submetidos à termociclagem, em temperaturas de $5^{\circ} \mathrm{C}$ e $55^{\circ} \mathrm{C}$, com 15 seg. em cada imersão, em um total de 500 ciclos. A seguir, os espécimes foram isolados e imersos em uma solução de fucsina básica a 0,5\% por 24 horas. A seguir foram seccionados em 4 ou 5 fatias e analisados segundo o grau de penetração do corante por escores pré-estabelecidos, por um microscópio com 40x de aumento. Analisados estatisticamente os resultados, o autor concluiu que: nenhum dos grupos experimentais foi capaz de bloquear totalmente a infiltração; não houve diferença estatística no grau de infiltração entre os cinco grupos; o grupo que recebeu secagem ostensiva de jatos de ar, apresentou uma maior porcentagem de índice máximo de infiltração. O autor ainda faz a observação de que nos grupos onde a dentina permaneceu visivelmente úmida, antes da aplicação do "primer", apresentaram uma maior quantidade de índice zero de infiltração. Sugerindo que a cavidade deve ficar visivelmente úmida antes da aplicação do "primer" para diminuir a infiltração marginal das restaurações de resina composta.

PASHLEY; CARVALHO ${ }^{148}$, em 1997, revisaram a literatura com o propósito de discorrer sobre a relação existente entre a permeabilidade dentinária e a difusão dos agentes adesivos, indicando a importância das características estruturais e morfológicas da dentina na criação de uma engrenagem mecânica ou camada híbrida e a influência dos procedimentos adesivos. Tanto a permeabilidade intratubular como a intertubular na dentina condicionada foram por eles consideradas indispensáveis para que a resina pudesse penetrar os túbulos e a rede de fibras colágenas expostas. Secar com ar é um procedimento que tem sido sempre usado, mas que pode produzir um efeito adesivo sobre esta permeabilidade devido à contração da rede de fibras colágenas expostas, aumentando a rigidez das mesmas, diminuindo as dimensões dos espaços interfibrilares (porosidades) e, assim comprometendo a completa e adequada interpretação dos agentes adesivos para formar a zona 
de dentina impregnada de resina. Manisfestaram, portanto, a importância de reumedecer a dentina desidratada com ar ou deixá-la visivelmente úmida antes da aplicação do primer. A presença de água permite a manutenção das fibras colágenas expandidas e melhor atuação dos agentes "primers" hidrofílicos. Acreditam também que o uso de um sistema que seja condicionador e "primer" ao mesmo tempo daria resposta às complicações dos sistemas com procedimentos separados.

Em 1997, CHAN et al. ${ }^{40}$, avaliaram a resistência ao cisalhamento de resina/dentina bovina por um período curto de estocagem (24 horas) e, por um período longo de estocagem (180 dias), a dentina foi condicionada com várias diluições de soluções aquosas de ácido fosfórico (1.0; 5.0; 10.0 e 37.0\%) e ácido maleico $(0.5 ; 1.0 ; 2.5 ; 5.0$ e 10.0\%) e ácido maleico a 10.0\% em forma de gel. A superfície da dentina foi preparada usando disco de papel com granulação 600 irrigada com água. A superfície da dentina foi condicionada em grupos de 10 dentes usando as várias diluições do ácido fosfórico e maleico. Usando o sistema Scotchbond Multipurpose e a técnica úmida de condicionamento da superfície, o primer e o adesivo foram aplicados sobre a superfície da dentina confinados ao cilindro de gelatina. Um cilindro de resina Z100 foi então fotopolimerizado e os espécimes foram então estocados em água por 24 horas ou 180 dias antes do teste de cisalhamento. Os resultados mostraram que uma alta força de união foi conseguida usando ácidos mais diluídos do que os comercialmente avaliados. Indicaram também que o ácido fosfórico não é o ácido de escolha para o sistema SBMP, e que o ácido maleico parece ser o condicionador de escolha para o sistema SBMP.

Em 1997, CAGIDIACO; FERRARI; DAVIDSON ${ }^{32}$, investigaram as diferenças entre a dentina condicionada com ácido orgânico e inorgânico, em condições clínicas e laboratoriais. Para o teste "in vitro" utilizaram 16 dentes anteriores extraídos por problema periodontal. Cavidades cilíndricas com diâmetro de $3 \mathrm{~mm}$ e profundidade de $2 \mathrm{~mm}$ foram confeccionadas e divididas em 2 grupos. O grupo 1 foi condicionado com ácido fosfórico em gel a 36\% por 15 segundos e lavados por 20 segundos. As amostras foram secas e fixadas com 
solução de formaldeído a $10 \%$ por 12 horas, e então seccionadas ao meio seguindo o longo eixo dos dentes na superfície lingual e depois fraturados com instrumentos manuais. O grupo 2 seguiu os mesmos passos do grupo $1 \mathrm{com}$ exceção do ácido, que neste grupo utilizaram a solução aquosa de ácido maleico a 10\%. Para o teste "in vivo" os autores utilizaram 8 dentes anteriores com sérios problemas periodontais indicados para extração, entretanto com vitalidade pulpar. As mesmas etapas seguidas para o teste "in vitro" foram seguidas para os testes "in vivo". O Grupo 3 foi condicionado como o Grupo 1; e o Grupo 4 como o Grupo 2. Depois foram cuidadosamente extraídos e tratados como nas amostras "in vitro". As amostras foram examinadas e comparadas por meio de um microscópio eletrônico de varredura. Depois de observadas as fotomicrografias os autores concluíram que os dois condicionadores ácidos são similarmente efetivos na completa remoção da smear layer e na desmineralização da dentina, proporcionando porosidades na rede de fibras colágenas; o condicionamento "in vitro" e "in vivo" produzem dentina micromorfologicamente similares e que o ácido fosfórico a 36\% e ácido maleico a $10 \%$ foram similarmente efetivos na desmineralização dentinária.

OWENS ${ }^{145}$, em 1997, avaliou "in vitro" a microinfiltração de restaurações em preparos de classe $\mathrm{V}$, utilizando ácido maleico a 10\% e resina composta. Distribuiu 30 molares humanos aleatória e proporcionalmente em 3 grupos. Os preparos foram confeccionados de forma circular com $1.5 \mathrm{~mm}$ de profundidade de $3 \mathrm{~mm}$ de diâmetro. O ângulo cavo-superficial foi localizado todo em esmalte e biselado. Depois de pronto, os preparos foram divididos em grupos de acordo com o preparo das paredes cavitárias: o Grupo1 recebeu condicionamento com ácido maleico a $10 \%$ por 15 segundos; o grupo 2 condicionamento com o mesmo ácido por 30 segundos e o Grupo 3 condicionamento por 60 segundos seguindo da aplicação do primer e adesivo do sistema Scothcthbond multi-purpose e então restaurados com a resina composta Z100 (3M). O acabamento e polimento foram realizados imediatamente com discos seqüenciais de Soflex. Os dentes restaurados foram armazenados em água deionizada por 7 dias e termociclados em banhos alternados de $4^{\circ} \mathrm{C}$ e $58^{\circ} \mathrm{C}$ por 100 ciclos, permanecendo 1 minuto em cada 
banho. Os dentes foram então cobertos por 2 camadas de esmalte para unha exceto $1 \mathrm{~mm}$ ao redor da restauração e colocados em uma solução de azul de metileno a $5 \%$ por 4 horas, lavados e secos. A seguir foram seccionados verticalmente no centro da restauração e as duas metade foram avaliadas segundo o critério de escores de 0 a 4. Depois de avaliados estatisticamente os resultados, o autor pôde concluir que a microinfiltração ocorreu em todos os grupos e que este estudo revelou que o ácido maleico a $10 \%$ mostrou resultados estatisticamente melhores quando utilizado por 30 segundos. Quando a dentina e o esmalte foram atacados por somente 15 segundos os dentes restaurados mostraram uma enorme infiltração. O autor sugere então que ao usar este ácido como condicionador, este seja utilizado por 30 segundos.

ALANI; TOH ${ }^{1}$, em 1997 fizeram uma revisão de várias técnicas usadas em estudos de microinfiltração como um guia para futuras investigações assim como auxiliar a avaliação clínica de pesquisas. Analisaram as várias técnicas utilizadas para teste de selamento cavitários "in vivo" e "in vitro". Observaram que os estudos "in vitro" incluem o uso de corantes, traçadores químicos; isótopos radioativos, pressão a ar; bactérias; ativação de newtrons; microscópio eletrônico de varredura, técnicas de cárie artificial, e condutibilidade elétrica. Com relação ao uso de corantes a revisão realizada pelos autores demonstrou que este é um dos métodos mais antigos e mesmo assim o mais comum para detectar infiltração "in vitro". Em geral são utilizadas soluções corantes ou suspensão de partículas de tamanhos diferentes. A concentração dos corantes variam entre $0,5 \%$ a $10 \%$, enquanto o tempo de imersão entre 4 horas a 72 horas ou mais. Os corantes fluorescentes são usados como traçadores por serem detectáveis em concentrações diluídas, não são caros, nem tóxicos e podem ser usados seguramente por clínicos, assim como em pesquisas laboratoriais. Notaram pouca ênfase aos diferentes tamanhos das moléculas e partículas dos corantes. Na revisão feita pelos autores sobre traçadores, perceberam que o método que utiliza o nitrato de prata é uma técnica bastante aceitável; entretanto vários testes mostraram que o tamanho dos íons de prata é extremamente menor $(0.059 \mu \mathrm{m})$, quando 
comparado com o tamanho das bactérias, portanto penetram mais, e que o sistema que previne a infiltração da prata também previne a infiltração de bactérias. De acordo com a revisão, algumas das vantagens do uso desta técnica são:- maior objetividade nas medidas, e poder coletar dados quantitativos para análise estatística paramétrica. Alguns estudos indicaram que os problemas encontrados com traçadores químicos são similares aos estudos que utilizam corantes, especialmente para interpretar os resultados. Um outro método bastante comum é o que envolve o uso de isótopos radioativos. Esse método permite detectar a quantidade de infiltração, e suas moléculas são bem menores $(40 \mathrm{~nm})$ que as partículas dos corantes que possuem o menor tamanho (120nm). Os traçadores mais usados são $\mathrm{Ca}^{45}$; $\mathrm{C}^{14} ; \mathrm{I}^{131} ; \mathrm{S}^{35}$, e $\mathrm{Na}^{22}$. A desvantagem deste método é a mesma de quando se utiliza corantes, ou seja, os resultados são subjetivamente avaliados pela extensão da infiltração demonstrada, e depende do plano da secção usada. Além de que os isótopos são bastantes caros, a técnica para utilização muito sensível com a possibilidade de penetração do isótopo por outros lugares que não seja a interface dente/restauração como por exemplo, trincas do esmalte dos espécimes. Os testes que utilizam bactérias para estudar infiltração produzem apenas resultados qualitativos, dependendo apenas da ausência ou presença de bactérias na fatia de dentina examinada. Este tipo de estudo é mais usado em experimentos clínicos, porque podem ser associados com processos cariosos e cáries recorrentes. Todos os testes bacterianos têm a desvantagem de que os resultados são descritos qualitativamente e não quantitativamente. O outro método de pressão a ar, foi introduzido por Harper em 1912. O exame microscópio da liberação de bolhas de ar das margens das restaurações, submergidas promove uma análise subjetiva do selamento marginal. A maior vantagem deste teste é o fato dos espécimes não necessitarem ser destruídos para a leitura. Um fator limitante seria o de não ser possível detectar se a infiltração foi completa do assoalho para as margens da cavidade . O método de cárie artificial tem sido produzido "in vitro" usando culturas bacterianas ou sistemas químicos, as técnicas de gel acidificado. As lesões produzidas por esta técnica são estudadas em luz polarizada, e duas partes são descritas: uma externa das lesão e uma na parede cavitária. A lesão 
externa resulta de ataque primário da superfície do esmalte adjacente à restauração enquanto as lesões da parede cavitária são formadas por microinfiltração de íons da gelatina acidificada ao redor das restaurações. $O$ uso desta técnica de avaliação demonstra a vantagem de que a microinfiltração pode ser unida diretamente com uma de suas possíveis conseqüências, isto é o desenvolvimento e extensão de cáries secundárias. A quantificação dos resultados é possível onde a profundidade da penetração da lesão é escolhida como um parâmetro mensurável e o grau de desmineralização pode também ser medido quantitativamente ou semi-quantitativamente. Essa técnica apresenta certas vantagens: - elimina as variáveis externas (substrato e microflora) associadas com a formação de cáries naturais, é eficiente em criar uma lesão cariosa dentro de um tempo relativamente curto, e a viscosidade do gel simula uma camada de placa. O uso do microscópio eletrônico de varredura promove, um método direto de visualização da adaptação do material restaurador às margens cavitárias devido a alta magnitude e profundidade do foco. Tem sido criticado pelo potencial de introduzir erros e artefatos, relativos à secagem, fraturas, distorção e seccionamento. É limitado para avaliação dos dentes fora do ambiente oral, a não ser quando usadas réplicas. Neste caso para medir a formação do microespaço entre as restaurações e paredes e assoalho da cavidade. Réplicas podem ser repetidas muitas vezes em diferentes intervalos de tempo e não muda a estrutura a ser avaliada. É difícil também quantificar os resultados desta técnica, e a técnica é limitada a demonstrar defeitos marginais. A análise de ativação de neutron é usada para testes "in vitro" e "in vivo". Os dentes restaurados são imersos em uma solução aquosa de um sal de magnésio não radioativo. Todo o sal aderido do lado do dente é então removido e o dente é colocado em um reator nuclear. Isto resulta em $\mathrm{Mn}^{55}$ não radioativo sendo ativado por $\mathrm{Mn}^{56}$, e a emissão de raio $\mathrm{x}$ do $\mathrm{Mn}^{56}$ formado durante a irradiação é então medida. O número de radioatividade contado é proporcional à quantidade de $\mu$ n por dente. Um ponto de vantagem deste estudo é que os resultados podem ser quantificados, mas segundo os autores as limitações das técnicas têm que ser ressaltadas, é uma técnica de alto custo e complexidade. A técnica que utiliza a condutibilidade elétrica tem sido usada para pesquisas endodônticas, é sensível e os resultados podem ser 
quantificados. O teste não demanda destruição dos espécimes e nem mudanças na dimensão do interespaço em períodos diferentes de tempo. Com relação à utilização dos testes de ciclagem térmica para o estudo da microinfiltração, os autores fizeram uma extensa revisão e observaram que quanto à necessidade do uso deste teste para se estudar microinfiltração, os trabalhos exibiram opiniões diversas, uns achavam necessário e outros não. As temperaturas usadas variam de $0^{\circ} \mathrm{C}$ e $68^{\circ} \mathrm{C}, 15^{\circ} \mathrm{C}$ e $45^{\circ} \mathrm{C} ; 4^{\circ} \mathrm{C}$ e $60^{\circ} \mathrm{C}, 5^{\circ} \mathrm{C}$ e $55^{\circ} \mathrm{C}$. Quanto ao tempo de imersão encontraram 10 segundos; 15 segundos; 30 segundos; 60 segundos e 120 segundos. Citam alguns autores que encontraram diferenças na penetração do corante em restaurações de amálgama, entretanto não encontraram o mesmo em restaurações de resina composta; concluíram então que durante a análise da microinfiltração, a necessidade da termociclagem vai depender da condutibilidade térmica do material. As pesquisas recomendaram também que os testes de termociclagem iniciassem somente depois de 24 horas para que a estocagem dos espécimes permita a sorpção de água pela resina primeiramente. O número de ciclos encontrados pelos autores também variam bastante na literatura de 1 a 2.500 . Uma das pesquisas analisadas mostrou não haver diferença na microinfiltração de compósitos termociclados com 250 e 1.000 ciclos. Alguns autores analisados mostram que os ciclos mecânicos podem aumentar a quantidade de deformação permanente ou somente enquanto o dente está sendo submetido a estresse. Outros autores sugerem que, na avaliação da microinfiltração em estudos no laboratório, dentes restaurados deveriam ser submetidos a estresse térmico e oclusal assim como no ambiente intra-oral, assim simulam mais rigorosamente o que acontece clinicamente. Depois da revisão feita, os autores chegaram à conclusão de que nenhum dos métodos é ideal para detectar a microinfiltração, provavelmente o mais prático método seja o de penetração de traçadores. Entretanto, os traçadores têm algumas desvantagens, mas quando comparados com outros métodos, eles promovem um efetivo método "in vitro" para comparação entre materiais restauradores e técnicas. Os isótopos radioativos têm vantagens sobre corantes e traçadores por sua presença ser detectada em pequenas concentrações. Quanto aos testes que usam microinfiltração são melhores examinados "in vivo". 
MATOS et al. ${ }^{118}$, em 1997, verificaram a ação de soluções ácidas na superfície dentinária, assim como avaliaram e mediram a extensão da desmineralização em profundidade, usando microscopia eletrônica (SEM). Discos de dentina de $3 \mathrm{~mm}$ de espessura foram obtidos do terço médio de terceiros molares humanos extraídos. Todos os discos de dentina foram preparados com ponta diamantada para formação da "smear layer". Em seguida foram aplicados vários ácidos sobre a superfície da dentina. Em um grupo utilizaram ácido fosfórico à $10 \%$ e nos outros à $35 \%$ e $37.5 \%$, e em outro ácido maleico a $10 \%$, por 15 segundos, lavados e secos. O grupo controle não recebeu tratamento algum. Os discos de dentina foram então fraturados, observados na superfície horizontal e também na superfície fraturada para avaliar a profundidade da desminerização. Os espécimes foram imersos em $4 \%$ de glutaraldeído fosfonado, e preparados para exame em SEM a 2000 vezes e 4000 vezes de aumento. Fotomicrografias foram realizadas para analisar a superfície horizontal da remoção da "smear layer" e a superfície fraturada para observar a profundidade da desmineralização. Depois de analisar as fotomicrografias os autores observaram que ocorreu a remoção da "smear layer" e a desmineralização e abertura dos túbulos dentinários com todas as concentrações de ácido fosfórico testadas mas com o ácido maleico a $10 \%$ ocorreu somente a remoção superficial da smear layer. O maior grau de desmineralização foi encontrado com o ácido fosfórico na concentração de $10 \%$ e $35 \%$ e uma menor desmineralização com 37,5\%, encontrando uma média de desmineralização em profundidade de $9,83 \mu \mathrm{m}$. Enquanto que com o ácido maleico ocorreu a remoção da "smear layer", mas não do "smear plug", portanto não desmineralizando a dentina em profundidade.

Em 1997, SCHUCKAR; GEURTSEN ${ }^{175}$, investigaram a influência da localização das margens próximo-cervicais na adaptação marginal de cavidades de Classe II restauradas com compósito; assim como a existência ou não de uma correlação entre o tipo ou qualidade do padrão de condicionamento ácido ou padrão de "tag" de resina na dentina e o selamento das restaurações próximo-cervicais. Sessenta molares humanos extraídos foram utilizados, o término cervical de suas cavidades foram os seguintes:- 
$1 \mathrm{~mm}$ ou $0,5 \mathrm{~mm}$ acima da junção cemento-esmalte, na junção cementoesmalte, e 0,5mm abaixo da junção cemento-esmalte. Todas as cavidades foram restauradas com uma resina composta híbrida (Tetric). A adaptação próximo-cervical e o selamento foram determinados antes e depois da termociclagem (2000 ciclos, $5-55^{\circ} \mathrm{C}$ ) com a utilização de microscopia eletrônica de varredura e testes de penetração de corante (solução de fucsina a 1\% por 24 horas). Depois das aplicações, os dados foram avaliados estatisticamente e foi encontrada uma diferença estatisticamente significante dependendo da localização das margens da cavidade. Quando esta se localizou $1 \mathrm{~mm}$ acima da junção amelo-cementária um excelente selamento marginal foi encontrado antes e depois da termociclagem; entretanto todos os outros grupos revelaram uma significante deterioração na integridade marginal depois da termociclagem. A utilização de adesivos dentinários melhorou significantemente o selamento marginal nas cavidades localizadas na junção amelo-cementária antes e depois da termociclagem, todavia a qualidade marginal não foi obtida como nos casos de estrutura de esmalte normal $1 \mathrm{~mm}$ acima da junção amelo-cementária com condicionamento ácido. Nas margens 0,5mm acima da junção amelo-cementária o adesivo dentinário somente melhorou a adaptação cervical antes da termociclagem. A avaliação das interfaces dente/restauração revelou que não houve correlação estatisticamente significante entre o padrão de condicionamento ácido e o padrão de "tag" de resina no interior da dentina e selamento marginal.

MIYAZAKI et al. ${ }^{127}$, em 1998, investigaram a influência da termociclagem na força de união à dentina de sistemas adesivos. Os sistemas adesivos utilizados foram os sistemas self-atching Fluoro Bond (FB). Liner Bond II (LB), e Mac Bond II (MB); e sistemas adesivos self-primer. One-step (OS). Optibond Solo (OB), Prime \& Bond 2.0 (PB) e Single Bond (SB). Utilizaram incisivos bovinos e as superfícies do esmalte e da dentina foram tratadas conforme instruções do fabricante, assim como a aplicação dos sistemas adesivos. A resina foi condensada em um molde de Teflon ( $4 \times 2 \mathrm{~mm}$ ), colocado sobre a superfície da dentina e fotoativado. Os espécimes foram divididos em quatro grupos: (a) estocado em água a $37^{\circ} \mathrm{C}$ por 24 horas; (b) 
estocados em água a $37^{\circ} \mathrm{C}$ por 24 horas seguido de ciclagem térmica entre $5^{\circ} \mathrm{C}$ e $60^{\circ} \mathrm{C}$ por 3.000 vezes; (c) 10.000 vezes e (d) 30.000 vezes. Cada grupo consistiu de 12 espécimes, testados com uma velocidade de $1 \mathrm{~mm} /$ minuto. Para os grupos FB, LB e MB, uma pequena diminuição na força de união foi observada e não houve diferenças significantes com os grupos termociclados. Para os adesivos OS, OB, PB e SB, uma significante diminuição na força de união foi observada para os grupos ciclados com 30.000 ciclos. As mudanças na força de união depois de termociclados foram diferentes para os sistemas adesivos.

GOES et al. ${ }^{80}$, em 1998, compararam as mudanças micromorfológica na superfície de esmalte e dentina depois do condicionamento por 15 ou 60 segundos com ácido fosfórico a 35\% e 10\%, e ácido maleico a 10\%, todos em forma de gel. 36 molares humanos extraídos foram utilizados, todos com a face vestibular hígida. As raízes dos dentes foram removidas e cada coroa foi montada horizontalmente com a face vestibular exposta. Os espécimes foram então divididos em dois grupos (Grupo I- esmalte e Grupo II= dentina) com 18 dentes cada grupo. Estes dentes foram então divididos dentro de 3 subgrupos de 6 dentes cada, baseados no tipo e concentração do ácido usado e o tempo de aplicação. Depois de preparados, a superfície do esmalte e da dentina receberam os seguintes tratamentos: ácido fosfórico a 35\%; ácido fosfórico a $10 \%$ e ácido maleico a $10 \%$. Os condicionadores foram aplicados por 15 e 60 segundos. Depois de condicionados os espécimes foram lavados com água destilada por 15 segundos e secos com ar por mais 15 segundos. A seguir os espécimes foram preparados para serem analisados ao microscópio eletrônico de varredura. Fotomicrografias foram então realizadas para as observações e comparações. Observaram que todas as superfícies condicionadas (esmalte e dentina) sofreram mudanças micromorfológicas independente do tipo do ácido, tempo e concentrações do condicionador. A superfície do esmalte atacado com ácido fosfórico a 35\% e 10\% por 15 e 60 segundos mostrou padrão de condicionamento similar. $O$ corpo dos prismas foi preferencialmente removido deixando a periferia dos prismas relativamente intactos, o mesmo acontecendo 
na superfície da dentina. O ácido maleico a $10 \%$ necessita de um tempo maior de condicionamento para promover retentividade no esmalte. E o mesmo ácido na dentina revelou resíduos de "smear layer" na superfície depois de 15 ou 60 segundos de aplicação, provavelmente porque o ácido é orgânico e tem alto peso molecular o que requer um tempo maior para reação na superfície da dentina.

OPDAM, ROETERS; BURGERSDIJK ${ }^{142}$, em 1998, investigaram algumas alternativas de sistemas adesivos na redução da microinfiltração em pequenos preparos tipo caixa de classe II. Os preparos foram confeccionados em 84 pré-molares humanos extraídos. A margem cervical foi localizada $2 \mathrm{mn}$ acima da junção cemento-esmalte. Todo ângulo cavo-superficial proximal foi biselado em $45^{\circ}$ com aproximadamente 0.5 a $1 \mathrm{~mm}$ de largura. Terminados os preparos, os dentes foram montados em mandíbula artificial com contato proximal, divididos em seis grupos que se diferenciaram de acordo com 0 tratamento do esmalte dentina (Tabela1).

TABELA 1: Seqüência restauradora dos grupos.

\begin{tabular}{l|c|c|c|c|c}
\hline \multicolumn{1}{c|}{ Grupo } & $\begin{array}{c}\text { Cimento } \\
\text { forrador }\end{array}$ & Condicionador & Primer & Adesivo & $\begin{array}{c}\text { Resina } \\
\text { Composta }\end{array}$ \\
\hline A (controle) & - & ác. fosfórico & - & Photo Bond & Clearfil Posterior \\
B & Vitrebond & ác. fosfórico & - & Photo Bond & Clearfil Posterior \\
C & - & ác. maleico & SBMP & SBMP & P50 \\
D & Vitrebond & ác. maleico & SBMP & SBMP & P50 \\
E & - & ác. fosfórico & SBMP & SBMP & P50 \\
F & - & - & Liner Bond 2 & Liner Bond 2 & Clearfil Posterior \\
\hline
\end{tabular}

Em seguida uma matriz transparente e uma cunha reflectiva foram adaptadas ao dente para que se pudessem realizar as restaurações. Ao final das restaurações, os dentes foram removidos das mandíbulas artificiais, receberam polimento, foram estocados em água por 24 horas e então termociclados (500 ciclos, $5^{\circ} \mathrm{C}$ e $55^{\circ} \mathrm{C}$ ). Depois da termociclagem os dentes foram cobertos com 2 camadas de esmalte para unha e imersos em fucsina básica por 24 horas. Passado este período foram embebidos em resina acrílica 
e seccionados no sentido M-D. As seções dos dentes foram avaliadas por 2 examinadores e classificadas segundo um critério de escores de 0 a 4 para infiltração marginal. O mais alto valor de infiltração encontrado para cada dente é que foi considerado para análise estatística. Obtiveram os seguintes resultados após a análise estatística: 1) na margem cervical, a infiltração foi ausente ou mínima para o grupo controle (PhotoBond/Clearfil Posterior); 2) na margem cervical houve um significante aumento na infiltração dos grupos $D$ (ácido maleico/ Vitrebond/SBMP/P50) e C (ácido maleico/SBMP/P50); 3) na margem oclusal, o grupo controle não apresentou infiltração; 4) na margem oclusal houve um significante aumento de infiltração nos grupos D (ácido maleico/ Vitrebond/SBMP/P50), C (ácido maleico/SBMP/P50), E (ácido fosfórico/SBMP/P50) e F (Liner Bond 2/Clearfil Posterior). A partir destes resultados puderam concluir que, para este tipo de restauração, os mais modernos adesivos dentinários não são os materiais de escolha do ponto de vista da microinfiltração. Os sistemas adesivos fosfonados usando a técnica do condicionamento com ácido fosfórico sem o uso de um primer produziram melhores resultados. A utilização de uma base de cimento de ionômero de vidro não contribuiu para a redução da microinfiltração.

Em 1999, LAMOSA et al. ${ }^{108}$, avaliaram o efeito da termociclagem na adesão de um adesivo de $5^{\mathrm{a}}$ geração (Prime \& Bond 2.1-Dentsply) à dentina de dentes humanos, pré-molares extraídos, através da medida da resistência ao cisalhamento e da infiltração marginal. Para o teste de cisalhamento, prepararam 20 corpos de prova, divididos em dois grupos $1 \mathrm{~A}$ e 1B, diferenciando-se na termociclagem. A resina utilizada foi a TPH Spectrum (Dentsply). Para os testes de infiltração marginal, outros 20 pré-molares extraídos foram utilizados, divididos também em dois grupos, $2 \mathrm{~A}$ e $2 \mathrm{~B}$, prepararam cavidades de Classe $\mathrm{V}$ com metade do cavo-superficial em esmalte e outra em cemento. Os materiais utilizados foram os mesmos dos outros grupos já citados. Metade dos corpos de prova foram submetidos à termociclagem, por 150 ciclos. Os corpos de prova 1A e 1B, foram testados na máquina Instron Universal, à uma velocidade de $5 \mathrm{~mm} / \mathrm{min}$.; e os grupo $2 \mathrm{~A}$ e 2B foram corados com solução de nitrato de prata a $50 \%$ e a infiltração 
avaliada por dois avaliadores, seguindo escores de 0 a 3 . As médias dos grupos $1 \mathrm{~A}$ e $1 \mathrm{~B}$ foram, respectivamente, $15,38+8,21$ e $17,70+6,74$. $\mathrm{E}$ os postos médios dos grupos $2 A$ e 2B foram, respectivamente, 28,19 e 30,56. Com os resultados obtidos, os autores concluíram não haver diferenças na resistência ao cisalhamento e infiltração marginal dos espécimes ciclados e não ciclados.

GALE; DARVELL ${ }^{76}$, em 1999, citaram a ciclagem térmica como um dos muitos fatores que simulam em testes laboratoriais o que acontece no ambiente oral para traçar penetração de bactérias, "gap" marginal e testes de união. Entretanto, as mudanças térmicas têm raramente sido confirmadas com as conseguidas "in vivo" e entre muitos estudos, sugeriram então uma padronização do teste. Estudaram dados de mudanças térmicas de 130 estudos laboratoriais de ciclagem térmica de 99 autores selecionados de 25 periódicos. Dentre estes a variação de técnicas utilizadas foi grande, e a comparação entre elas bastante difícil. Relataram que os efeitos da ciclagem térmica são freqüentemente contraditórios, mas geralmente aumentam a infiltração marginal, mas nunca demonstraram relevância nas falhas clínicas. Definiram como padronização cíclica a seguinte; $35^{\circ} \mathrm{C}$ (28 segundos), $15^{\circ} \mathrm{C}(2$ segundos), $35^{\circ} \mathrm{C}$ (28 segundos), $45^{\circ} \mathrm{C}$ (2 segundos). Não evidenciaram 0 número de ciclos prováveis para experiência "in vivo" e sugeriram investigações sobre isto, mas um número estimado de número de ciclos por ano de 10.000 foi sugerido. Afirmaram que o estresse térmico da interface das restaurações somente tem valor quando a união inicial é conhecida para ser considerado seguro. $E$ isto não é comum em materiais restauradores.

Em 1999, BENDERLI; YÜCEL ${ }^{13}$, compararam quatro ácidos, com dois tempos de aplicação cada e o seu efeito na resistência à tração de uma resina composta. Utilizaram terceiros molares recém extraídos e armazenados em solução salina a $4^{\circ} \mathrm{C}$ por um tempo de três semanas. Os dentes foram seccionados em 3 partes e o terço central foi utilizado para os testes. Este disco de dentina foi ainda dividido em 4 partes iguais e cada parte foi desgastada até se obter um disco de dentina de $3 \mathrm{~mm}$ de altura e $5 \mathrm{~mm}$ de 
diâmetro . Quatro diferentes ácidos foram aplicados passivamente em cada porção de dentina exposta (ácido fosfórico/ ácido maleico; Na- EDTA; ácido cítrico ), e dois tempos diferentes (15 e 60 segundos). O adesivo dentinário utilizado foi o Prisma Universal Bond 2 e a resina logo a seguir foi a Heliolux. Depois de prontos os espécimes foram armazenados em água destilada a $37^{\circ} \mathrm{C}$ por uma semana. $\mathrm{O}$ grupo controle recebeu os mesmos procedimentos com exceção da aplicação do ácido. Passado o período de estocagem, os espécimes foram levados até a máquina de testes Universal e a resistência à tração foi medida em uma velocidade de $1 \mathrm{~mm} /$ minuto, e o resultado expresso em $\mathrm{MPa}$. O ácido fosfórico aplicado por 15 segundos obteve uma resistência de $129 \mathrm{MPa}$, e com 60 segundos, $63 \mathrm{MPa}$; o ácido maleico com 15 segundos de aplicação $90 \mathrm{MPa}$, com 60 segundos, 149MPa; o $\mathrm{Na}$-EDTA com 15 segundos, $58 \mathrm{MPa}$; com 60 segundos, $69 \mathrm{MPa}$; o ácido cítrico com 15 segundos obteve uma resistência de $196 \mathrm{MPa}$ e com 60 segundos, $56 \mathrm{MPa} /$ e o grupo controle $57 \mathrm{MPa}$. Analisando os resultados os autores concluíram que: a aplicação de ácidos fortes (ácido cítrico ou fosfórico) na superfície de dentina por 15 segundos deram significantemente maiores valores de união do que com a aplicação de 60 segundos; a utilização de ácidos fracos (maleico ou $\mathrm{Na}$ EDTA) na dentina por 15 segundos diminuiu significantemente os valores de adesão comparados com 60 segundos de aplicação; os maiores valores de adesão foram obtidos com a aplicação do ácido maleico por 60 segundos ou ácido fosfórico por 15 segundos ou ácido cítrico por 15 segundos; o aumento do tempo de aplicação resultou em um aumento significante de união para os ácidos fracos mas uma diminuição significante para ácidos fortes.

YAMAUTI $^{204}$, em 1999, avaliou a microinfiltração marginal de restaurações em resina composta utilizando duas técnicas de inserção do material e formas de fotoativação distintas. Foram confeccionadas cavidades de Classe $V$, em forma circular, nas faces vestibular e lingual de dentes terceiros molares humanos extraídos. As cavidades foram restauradas com o sistema adesivo Single Bond/Z-100 (3M do Brasil). Os dentes foram divididos em 10 grupos de aproximadamente 10 dentes cada, que diferiram entre si de acordo com a técnica de inserção da resina no interior da cavidade e de acordo 
com a forma de fotoativação do material, da seguinte forma: G1- inserção única com intensidade máxima $\left(560 \mathrm{~mW} / \mathrm{cm}^{2}\right)$; G2- inserção única com fotoativação gradual, partindo de uma intensidade mínima $\left(180 \mathrm{~mW} / \mathrm{cm}^{2}\right)$ por 20 seg. até atingir a intensidade máxima por 40 seg.; G3- inserção única com fotoativação gradual a partir de intensidade média $\left(280 \mathrm{~mW} / \mathrm{cm}^{2}\right)$ por $20 \mathrm{seg}$. até a máxima por 40 seg.; G4, G5 e G6- inserção incremental e fotoativação de acordo com G1, G2 e G3, respectivamente; G7- inserção única com uma distância de 10 $\mathrm{cm}$ entre a extremidade da ponta ativa da unidade fotoativadora por $29 \mathrm{seg}$. até atingir a superfície da restauração em 40 seg.; G8- inserção única com distância de $5 \mathrm{~cm}$, durante os mesmos períodos de tempo; G9 e G10- inserção incremental com a mesma forma de fotoativação que os grupos G7 e G8, respectivamente. Os espécimes foram submetidos à termociclagem $\left(500 \mathrm{x}, 5^{\circ} \mathrm{C}\right.$ e $55^{\circ} \mathrm{C}$, com duração de $30 \mathrm{seg}$. cada ciclo) e imersão em solução de nitrato de prata a $50 \%$. Cada dente foi seccionado em cortes de $0.5 \mathrm{~mm}$ e foi escolhido o corte de maior infiltração, no qual foi medido o grau de infiltração linear do corante, em $\mathrm{mm}$, de cada corte. Os resultados mostraram que as formas de inserção e de fotoativação independem entre si no que se refere à infiltração marginal. A fotoativação gradual, partindo de uma intensidade média até a máxima, obteve os menores graus de infiltração, apresentando melhor selamento marginal. Em seguida, em ordem crescente de infiltração, a autora classificou os resultados obtidos, da seguinte forma: fotoativação gradual de intensidade mínima a máxima, com distância de $5 \mathrm{~cm}$, com intensidade máxima e com distância de $10 \mathrm{~cm}$. Pode-se concluir que a forma de fotoativação gradual apresentou bom desempenho no selamento marginal das restaurações.

Com o objetivo de estudar a efetividade do vedamento marginal de diferentes materiais aplicados no terço cervical com término em cemento, em associação à restauração de resina composta de cavidades de Classe II, MONDELLI ${ }^{132}$, em 1999, avaliou o índice de infiltração marginal na interface cemento/material restaurador. Preparou cavidades M.O.D. com margens cervicais estendidas além da junção amelocementária em 60 pré-molares humanos, livres de cárie, os quais foram distribuídos em grupos de 10 dentes 
cada, correspondendo a 5 condições experimentais : G. controle- em todos os dentes, Scotchbond MP/Z-100; G1- Scotchbond MP/Concise/Scotchbond MP/Z-100; G2- Alpha Bond/ Natural Flow/ Scotchbond MP/ Z-100; G3- One Step/Aeliteflo/ Scotchbond MP/Z-100; G4- Prime \& Bond 2.1/DyractAP/Scotchbond MP/Z-100; G5- Verniz copalite/ Velvalloy/Scotchbond MP/ Z100. Após 48 horas, as restaurações foram polidas e submetidas à ciclagem por carregamento oclusal correspondendo a 200 ciclos. Terminada a ciclagem, os espécimes foram armazenados 24 horas em água destilada a $37^{\circ} \mathrm{C}$, e os dentes preparados para a termociclagem, que foi realizada em azul de metileno a $2 \%$, por 180 ciclos de 45 seg. cada, nas temperaturas de $58^{\circ} \mathrm{C}, 37^{\circ} \mathrm{C}$ e $55^{\circ} \mathrm{C}$. Os dentes foram então seccionados e avaliados por uma escala de escores pré-estabelecidos. O autor encontrou os seguintes resultados: o amálgama Velvalloy e a resina composta Z-100, usada como controle, apresentaram, respectivamente, os índices mais severos de infiltração marginal; houve diferença estatística significante entre o Dyract-AP e os demais materiais testados, que reduziu consideravelmente o índice de infiltração marginal nas interfaces; a resina quimicamente ativada Concise e as fluídas Aeliteflo e Natural Flow, ocuparam uma posição intermediária com relação à infiltração, com desempenho estatisticamente igual entre si e desfavorável em relação ao Dyract AP, mas sobressaíram-se positivamente quando comparadas como amálgama; entretanto, nenhum material testado impediu $100 \%$ a penetração do corante nas margens cervicais em cemento.

Também em 1999, BOTELHO ${ }^{17}$, estudou a efetividade do vedamento marginal de diferentes materiais aplicados no terço cervical com término em cemento, associados à resina composta, para restauração de cavidades de Classe II. Confeccionou cavidades do tipo M.O.D., com margens cervicais estendidas além da junção amelocementária em 84 dentes, premolares humanos livres de cárie, que foram distribuídos em grupos de 12 elementos cada e divididos em 7 grupos: G1- (controle) Scotchbond MP/Z-100; G2- verniz Copalite/ Dispersalloy/Scotchbond MP/Z-100; G3Vitremer/Scotchbond MP/Z-100; G4- Prime \& Bond 2.1/Dyract/Scotchbond MP/Z-100; G5- Prime \& Bond 2.1/Dyract-AP/Scotchbond MP/Z-100; G6- 
Stae/Freedom/Scotchbond MP/Z-100; G7- One Step/Bisfil-2B/Z-100. As restaurações foram polidas após 24 horas e a seguir submetidas a ciclagem térmica, por 500 ciclos de 20 seg. cada, nas temperaturas de $5^{\circ} \mathrm{C}$ e $55^{\circ} \mathrm{C}$. Imediatamente após a ciclagem os dentes foram preparados para serem imersos em solução de azul de metileno à $2 \%$, por 24 horas, mantidos à $37^{\circ} \mathrm{C}$. Os dentes foram então incluídos em resina e seccionados em aproximadamente 4. Os graus de penetração do corante foram avaliados por uma escala de escores pré- determinados. O autor obteve os seguintes resultados: nenhum material impediu totalmente a penetração do corante; 0 Dyract AP e o Vitremer promoveram respectivamente, os melhores resultados de selamento marginal, não havendo diferenças significantes entre eles; o Bisfil-2B, ocupou uma posição intermediária, diferenciando-se estatisticamente dos demais materiais, sendo porém de maneira desfavorável em relação ao Dyract-AP e ao Vitremer e favorável em comparação ao Dispersalloy, Z-100 e Freedom, os quais apresentaram, nesta ordem, os piores índices de infiltração marginal, não ocorrendo entre os mesmos diferenças estatísticamente significantes; com relação às interfaces entre os materiais resinosos testados, o autor observou, que se apresentaram praticamente isentas de infiltração, entretanto na interface amálgama/resina composta a infiltração foi severa.

RASKIN et al. ${ }^{157}$, em 2000, relacionaram e classificaram os fatores metodológicos que influenciam os resultados dos testes de microinfiltração. Estudaram 147 testes "in vitro" de microinfiltração, publicados em 14 revistas internacionais entre 1992 e 1998, correspondendo a 917 grupos experimentais. Realizaram um registro destes estudos com algums critérios selecionados na literatura: amostras (substrato, tempo de estocagem e meio depois da extração), cavidades (tipo, forma, bisel, dimensões), procedimentos restauradores (bases, adesivos, materiais, forma de polimerização, polimento), termociclagem e ciclagem mecânica (número de ciclos), avaliação (corante/traçador, critério, estatística). Observando os resultados, notaram que muitos destes fatores parecem influenciar na efetividade destes testes e merecem ser analisados: meio de conservação dos dentes após a extração, termociclagem, corante/traçador, estocagem do espécime em corante/traçador 
depois da restauração e número de secções. Das pesquisas avaliadas, os autores relataram as ocorrências mais freqüentes de alguns ítens avaliados: Estocagem do espécime após a extração: duração $(59,21 \%$ trabalhos não especificaram), meio de estocagem (34,52\% em água deionozada), temperatura de estocagem (53,34\% não especificaram), aditivos na estocagem (46,55\% não usam). Termociclagem: 88,05\% utilizam; espera antes da termociclagem (35,71\% esperam 24 horas), meio antes da termociclagem ( $26,65 \%$ em água deionizada), temperatura antes da termociclagem (47,39\% à $\left.37^{\circ} \mathrm{C}\right)$, meio em que realiza a ciclagem $(50,27 \%$ em água), número de ciclos (34,61\% de 250 a 500 ciclos), temperatura dos banhos (60,57\% realizam em $5^{\circ} \mathrm{C}$ e $55^{\circ} \mathrm{C}$ ), número de banhos (83,97\% em dois banhos), duração do banho (44,26\% por 30 segundos). Corante/traçador: tipo (40,68\% em fucsina básica), duração de imersão (39,80\% por 24 horas), e período de imersão $(64,12 \%$ depois da termociclagem). Secções: direção (81,13\% perpendicular), e número de secções (42,86\% em apenas uma). Depois de avaliarem estes dados, os autores concluíram que a complexidade de comparações de resultados, registrados neste estudo, é conseqüência da grande variabilidade de métodos usados. Conseqüentemente, é impossível realizar uma padronização dos testes de microinfiltração "in vitro".

Os mesmos autores do resumo acima, RASKIN et al. ${ }^{158}$, também em 2000, divulgaram após a análise dos inúmeros trabalhos realizados "in vitro", os critérios e métodos estatísticos utilizados. Classificaram os estudos de acordo com o método estatístico e número de dentes de cada amostra. Avaliaram 147 testes "in vitro", publicados em 14 revistas internacionais entre 1992 e 1998, correspondendo a 917 grupos experimentais. 


\begin{tabular}{l|c|l|c}
\hline \multicolumn{1}{c|}{ Critério de avaliação } & $\%$ & Método estatístico & $\%$ \\
\hline Média & 30.10 & Nenhum (N) & 4.25 \\
Mediana & 1.20 & Paramétrico (P) & 24.54 \\
Máximo & 22.68 & Não paramétrico (NP) & 65.87 \\
Mínimo & 0.22 & Param. e N. Param. (N\&NP) & 2.40 \\
Freqüência relativa & 6.43 & Estatística descritiva (D) & 0.11 \\
Outros & 8.61 & Não especificado (U) & 2.84 \\
Não especificado & 10.75 & & \\
\hline
\end{tabular}

\begin{tabular}{l|c|c|c|c|c|c}
\hline $\begin{array}{l}\text { Mét. Estatístico(\%) }-\mathbf{n}^{\circ} \text { de } \\
\text { dentes }\end{array}$ & $\mathbf{N}$ & $\mathbf{P}$ & $\mathbf{N P}$ & $\mathbf{N} \& \mathbf{N P}$ & $\mathbf{D}$ & $\mathbf{U}$ \\
\hline & 3.93 & 11.01 & 45.80 & 2.40 & 0 & 2.62 \\
$<\mathrm{ou}=10$ & 0.11 & 6.22 & 10.64 & 0 & 0.11 & 0.22 \\
$>10 \&<20$ & 0.22 & 7.31 & 3.40 & 0 & 0 & 0 \\
\hline
\end{tabular}

Com base nestes dados os autores concluíram que, mais de $30 \%$ dos estudos não especificam os critérios utilizados para avaliar a microinfiltração e os métodos estatísticos mais freqüentemente escolhidos, foram os não paramétricos, independente do número de dentes utilizados.

MOLL; WÖRLE; HALLER ${ }^{130}$, em 2000, avaliaram o efeito de diferentes corantes no resultado de testes de microinfiltração. Confeccionaram 90 cavidades de Classe V, com margen gengival em dentina. Os dentes foram divididos em 3 grupos, que se diferenciavam pelo sistema restaurador (RS): Optibonb FL/Herculite XRV (OPT/HER); Prime \& Bond NT/TPH Spectrum (P\&B/TPH); Prompt L-Pop/Pertac II (PLP/PER). Depois da termociclagem, os espécimes (sempre trinta de cada sistema restaurador) eram imersos em 
fucsina básica a 0,5\% (BF); azul de metileno a 0,5\% (MB) e nitrato de prata a $50 \%$ (SN). Os dentes foram então seccionados em 3 partes e a penetração do corante na interface dente material restaurador $(A)$ e até a polpa $(B)$, foi medida por um microscópio óptico. Os resultados estão descritos na tabela abaixo.

\begin{tabular}{lcc|c|c|c|c}
\cline { 2 - 7 } & \multicolumn{2}{c|}{ OPT/ KER } & \multicolumn{2}{c|}{ P\&B/ TPH } & \multicolumn{2}{c}{ PLPI PER } \\
\hline Corante & A (mm) & B (mm) & A (mm) & B (mm) & A (mm) & B (mm) \\
\hline BF & 0.06 & 0.01 & 0.82 & 0.24 & 2.57 & 0.84 \\
MB & 0.09 & 0.01 & 1.78 & 0.96 & 3.31 & 1.43 \\
SN & 0.70 & 0.23 & 3.74 & 1.17 & 2.88 & 0.98 \\
\hline
\end{tabular}

Analisando os resultados, os autores concluíram que o sistema Optibond FL/Herculite XRV apresentou menor grau de infiltração que os outros dois sistemas avaliados, e que o resultado da microinfiltração pode ser influenciado pelo corante usado. Em adição, salientaram que parece haver uma interação entre os corantes e o sistema restaurador, o que merece atenção em futuras pesquisas.

VERONEZI et al. ${ }^{198}$, em 2000, avaliaram a eficácia de dois selantes superficiais na prevenção de infiltração marginal de restaurações de resina composta. Confeccionaram cavidades circulares em 17 terceiros molares humanos extraídos, com a margem oclusal localizada em esmalte e a gengival em cemento. O sistema restaurador utilizado foi o Probond/TPH (Dentsply-Caulk). As restaurações foram polidas depois de 24 horas e divididas em três grupos: G.I: sem tratamento superficial das restaurações (controle); G. II: tratamento superficial com Fortify (BISCO); G. III: tratamento superficial com Protect-it (Jeneric/Pentron). Os dentes foram então submetidos a ciclagem térmica ( 200 ciclos de $5^{\circ} \mathrm{C}$ e $55^{\circ} \mathrm{C}$, por 15 segundos cada) e imersos em 
solução de fucsina básica à $0,5 \%$ por 24 horas. Depois disto, os dentes foram embebidos em resina e seccionados vestibulo-lingualmente em aproximadamente 4 cortes. A profundidade de penetração do corante foi expressa por escores pré-estabelecidos de 0 a 4 . A análise estatística dos resultados, permitiu aos autores concluir que os selantes superficiais mostraram-se estatisticamente superiores na prevenção de penetração do corante quando comparados com o grupo controle, entretanto não eliminaram totalmente a infiltração marginal. 
3 - PROPOSIÇÃO 


\section{3- Proposição}

Este trabalho teve como objetivo verificar a influência do número de ciclos no processo de termociclagem fenômeno de microinfiltração marginal de restaurações de resina composta, assim como, de comparar os métodos de avaliação quantitativos (medida linear e da área do corante penetrado na interface dente/restauração) e qualitativo (escores pré-estabelecidos) dos espécimes. 


\section{4 - MATERIAL E MÉTODOS}




\section{4- Material e Métodos}

\subsection{Preparo cavitário e restauração com resina composta}

Neste estudo foram utilizados 76 pré-molares humanos, extraídos por indicação ortodôntica. Depois de extraídos, os dentes foram limpos com curetas periodontais e armazenados em água destilada e mantida a $10^{\circ} \mathrm{C}$, por um período máximo de 6 meses até sua utilização. Os dentes foram aleatoriamente divididos em quatro grupos de 19 dentes cada um. Em cada dente foi preparada uma cavidade circular com o ângulo cavo-superficial localizado totalmente em cemento.

Estas cavidades eram confeccionadas de uma forma padronizada, inicialmente com ponta diamantada cone-invertida no 1036 (K.G. Sorensen) até que se conseguisse um diâmetro de $3 \mathrm{~mm}$, e a seguir aprofundava-se as cavidades até atingirem $1,5 \mathrm{~mm}$, com a broca carbide $n^{0} 245$ (S. S. White). As dimensões foram controladas com uma sonda milimetrada. Ambas, ponta diamantada e broca carbide foram utilizadas em alta velocidade e refrigeradas com spray ar/água e a cada cinco preparos eram substituídas. $O$ acabamento das cavidades foi executado com a mesma broca carbide if 245 (S. S. White) em baixa velocidade e recortadores de margem gengival, tomando-se o cuidado de não ampliar demasiadamente o diâmetro do preparo. (Figura 4.1) 


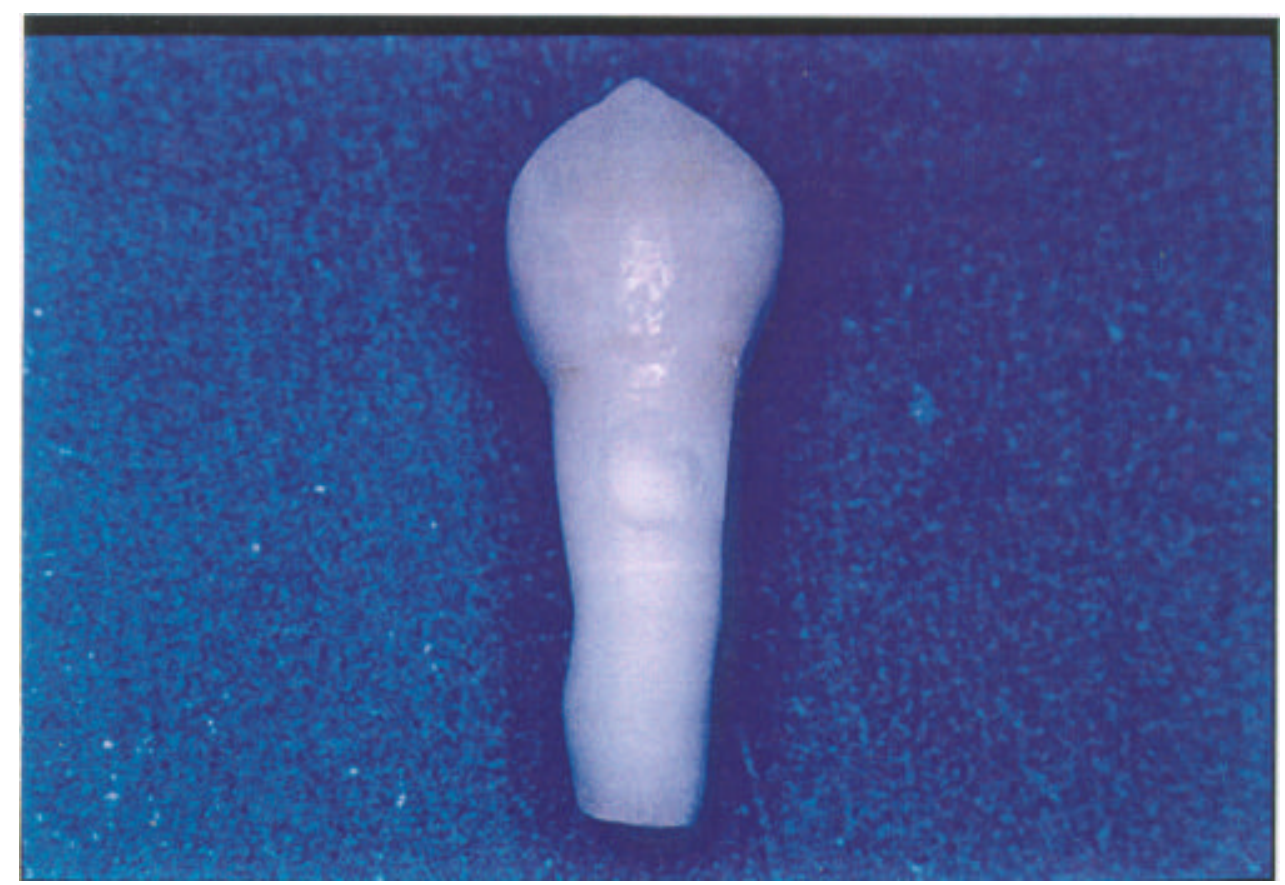

FIGURA 4.1. Aspecto do preparo cavitário realizado na superfície radicular (cemento).

A seguir, os preparos foram restaurados com resina composta $Z$ 100 (3M), cor C3, utilizando-se inicialmente o Sistema Adesivo Scotchbond Multi Uso Plus (3M) (Figura 4.2), de acordo com instruções do fabricante, ou seja, aplicação do ácido maleico à $10 \%$, por 15 segundos em toda a cavidade, lavagem por mais 15 segundos, e secagem da cavidade por 2 segundos com jato de ar, evitando-se assim o ressecamento da dentina e o colapso das fibras colágenas $^{43,138}$. Depois disso, o Primer foi depositado no interior da cavidade e um jato de ar foi aplicado por 5 segundos sobre o mesmo. A seguir, o adesivo foi pincelado sobre toda a cavidade e margens do preparo e um leve jato de ar foi aplicado para diminuir sua espessura e tornar esta camada mais homogênea para então ser fotopolimerizada (Curing Light XL 1500 - 3M Dental Products) por 20 segundos. 


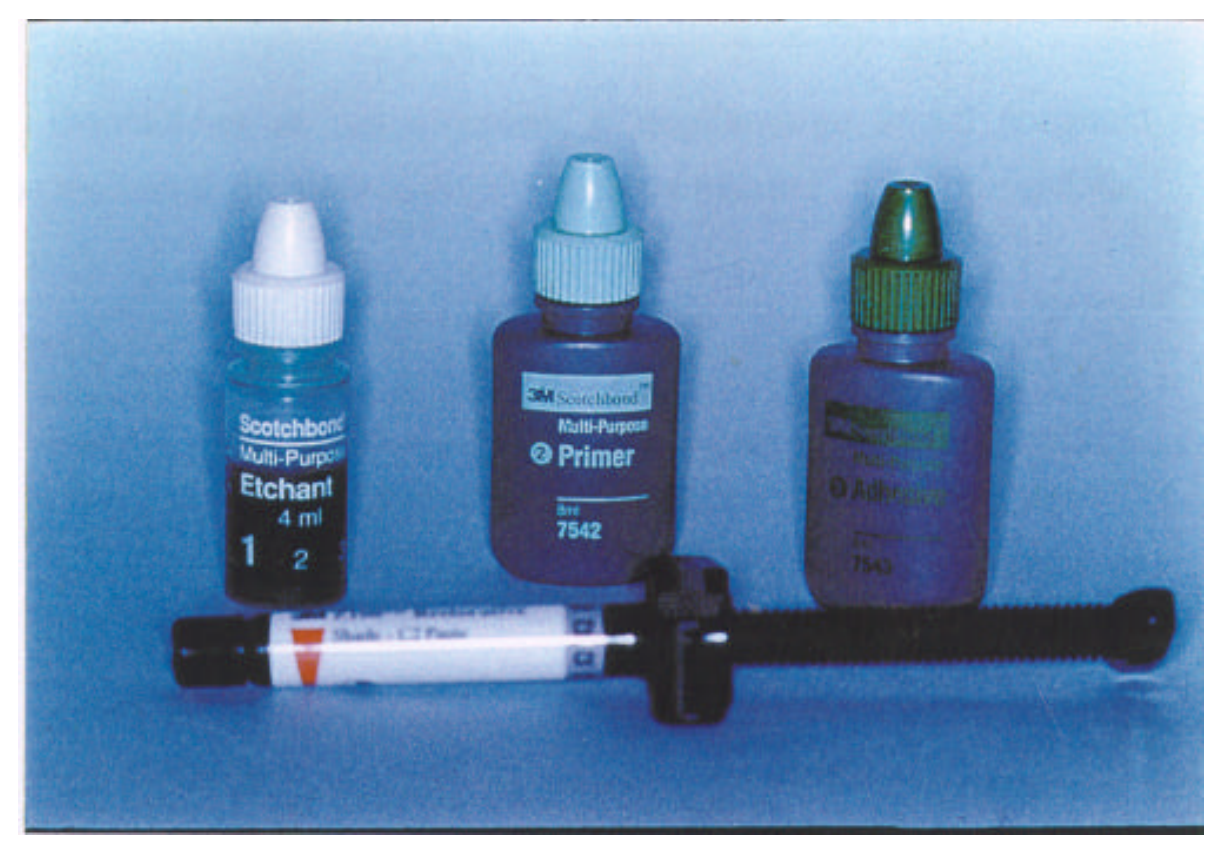

FIGURA 4.2. Sistema restaurador utilizado, Scotchbond Multi Uso Plus/Z-100.

E finalmente, a resina composta Z - 100 (3M), cor C3, foi inserida no interior da cavidade com espátula Teflon pela técnica incremental em três porções, e cada camada fotopolimerizada por 40 segundos de acordo com a Figura 4.3, na tentativa de diminuir o microespaço formado entre as paredes do preparo cavitário e o material restaurador.

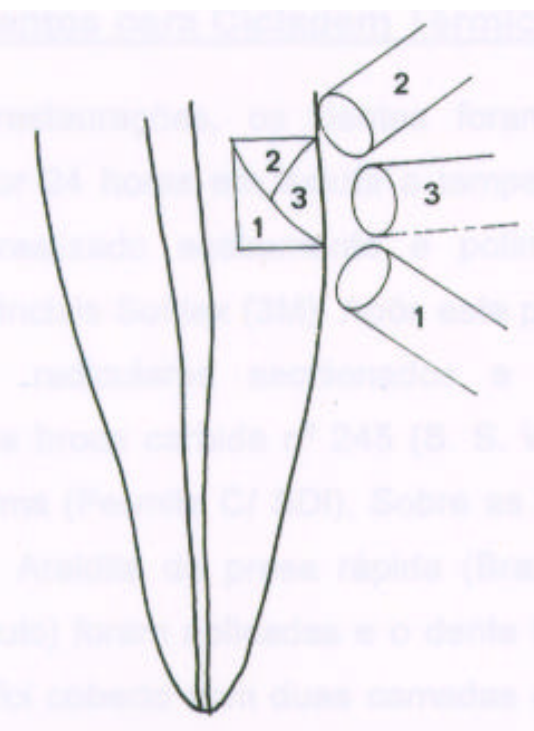

FIGURA 4.3. Seqüência de inserção e fotopolimerização das camadas de resina composta. 
Concluídas as restaurações, o acabamento inicial consistiu na remoção dos excessos grosseiros com lâmina de bisturi n. 15. (Figura 4.4)

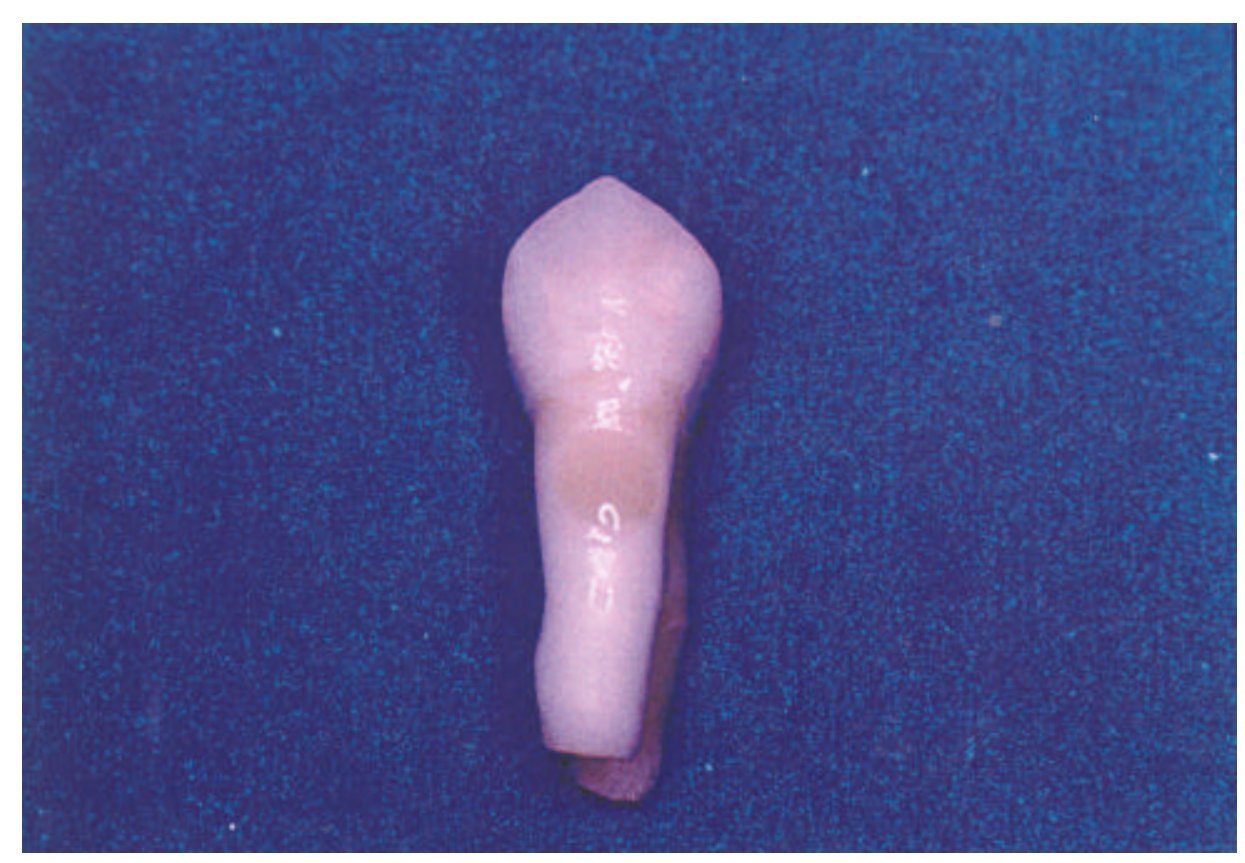

FIGURA 4.4. Aspecto do preparo cavitário restaurado.

\subsection{Procedimentos para Ciclagem Térmica}

Terminadas as restaurações, os dentes foram armazenados imersos em água destilada, por 24 horas em estufa a temperatura de $37^{\circ} \mathrm{C}$. Passadas as 24 horas foi realizado acabamento e polimento final das restaurações com discos seqüênciais Sof-lex (3M). Após este procedimento, os dentes tiveram seus ápices radiculares seccionados e seus condutos radiculares ampliados com uma broca carbide rf 245 (S. S. White) e em seu interior foi condensado amálgama (Permite C/ SDI). Sobre as restaurações de amálgama, duas camadas de Araldite de presa rápida (Brascola Ltda, São Bernardo do Campo - São Paulo) foram aplicadas e o dente todo, inclusive o ápice já previamente vedado, foi coberto com duas camadas de esmalte para unha (Colorama - CEIL. Coml. Exp. Ind. Ltda - São Paulo) em cores diferentes para cada grupo, deixando apenas $1 \mathrm{~mm}$ ao redor da restauração sem o devido 
isolamento, para que por esta área fosse possível a penetração do corante (Figura 4.5).

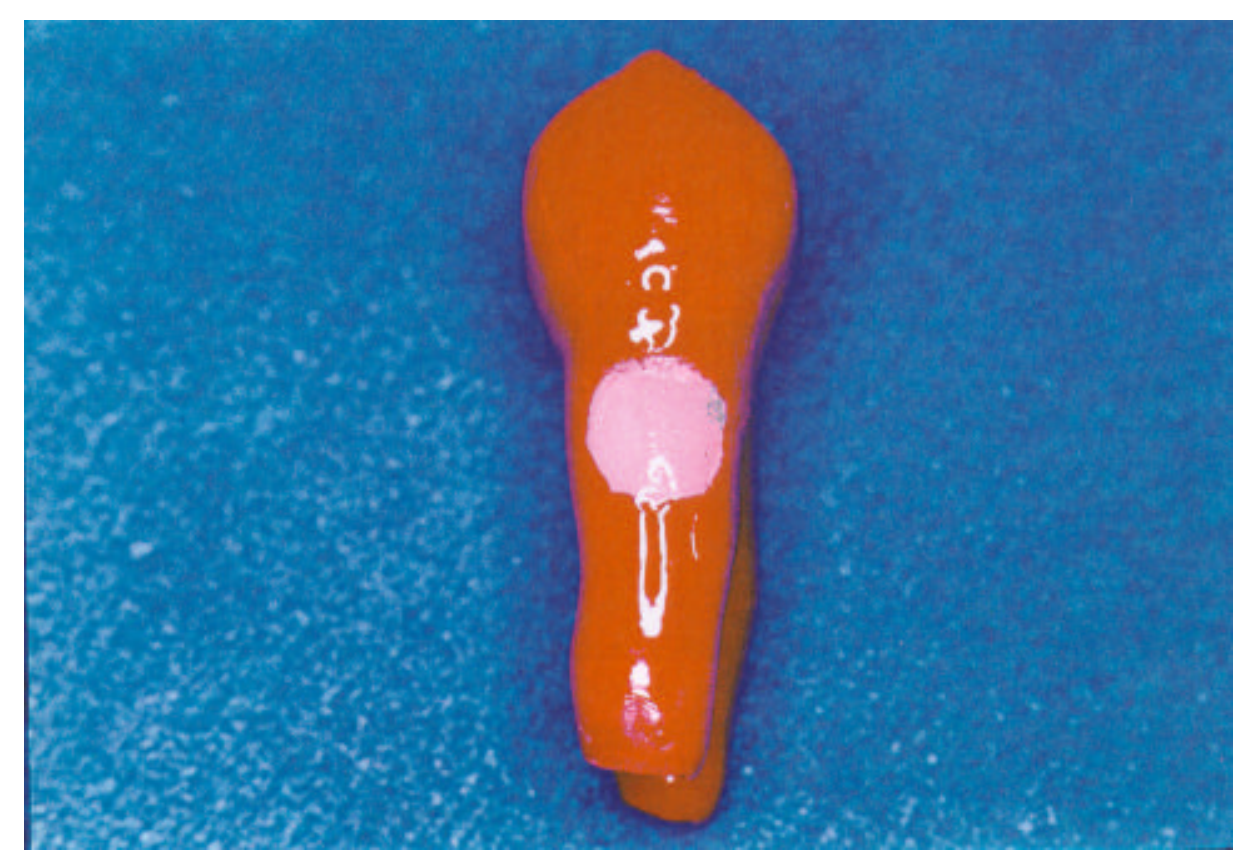

FIGURA 4.5. Espécime coberto por esmalte para unha, com exceção de $1 \mathrm{~mm}$ ao redor da restauração de resina composta.

Aguardou-se 1 hora para a secagem do esmalte e a seguir os dentes foram submetidos à ciclagem térmica em um aparelho próprio para este fim (Ética - Equipamentos Científicos S. A. - São Paulo).(Figura 4.6) 


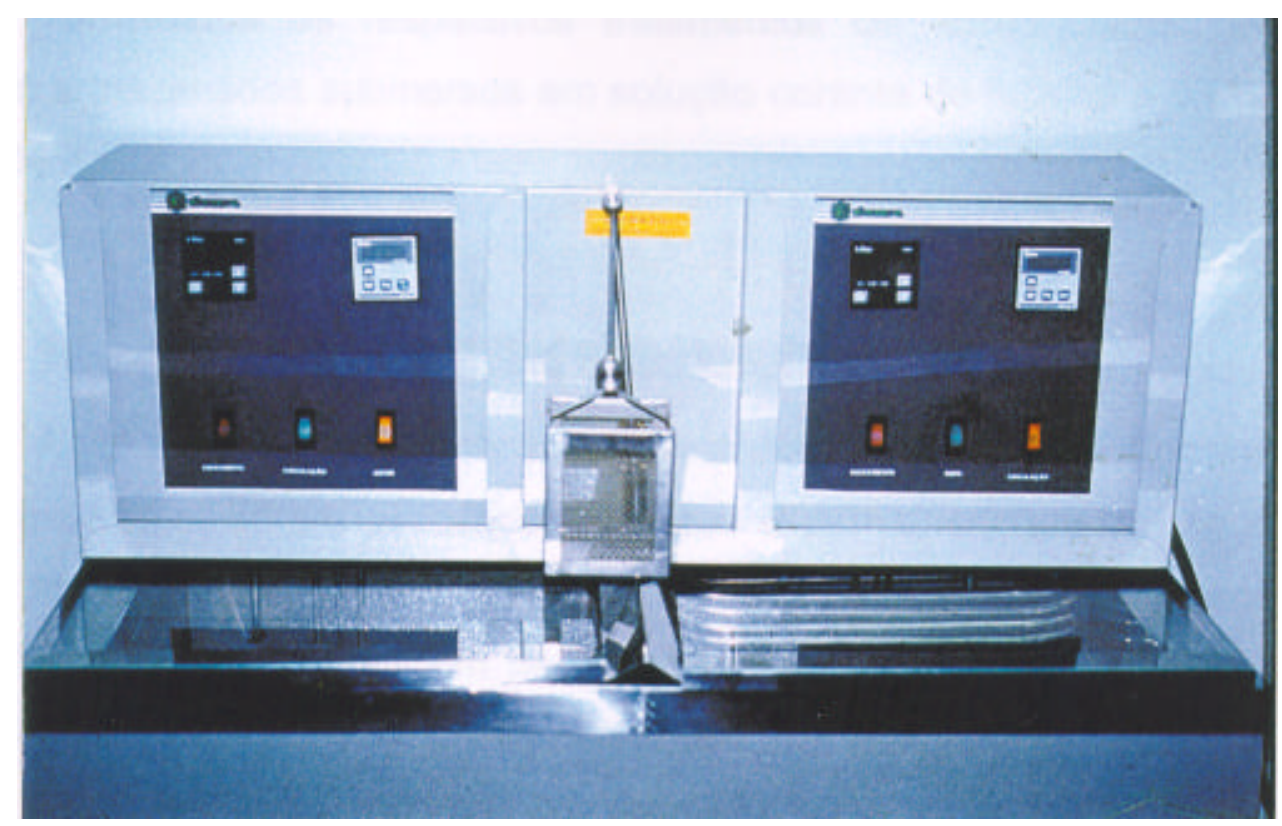

FIGURA 4.6. Máquina utilizada para ciclagem térmica dos espécimes (Ética - Equipamentos Científicos S. A. São Paulo) .

Foram utilizados quatro grupos de ciclagem térmica que se diferenciaram apenas no número de ciclos a que foram submetidos. Os grupos receberam o seguinte tratamento, terminadas as 24 horas em $37^{\circ} \mathrm{C}$ e executados os procedimentos de acabamento e polimento final das restaurações, os dentes sofreram ciclagem térmica em duas temperaturas, $5^{\circ} \mathrm{C}$, conseguida em uma das cubas da máquina de ciclagem e $55^{\circ} \mathrm{C}$, em uma outra cuba da mesma máquina. Em cada temperatura, controladas por um termômetro, os espécimes de todos os grupos permaneceram por 15 segundos, totalizando um ciclo completo em 30 segundos, até que se completasse o número de ciclos estabelecidos para cada grupo. O número de ciclos para cada grupo foi o seguinte:

Grupo 1: não submetido à ciclagem térmica e foi considerado como grupo controle;

Grupo 2: $\quad$ submetido a 100 ciclos;

Grupo 3: submetido a 200 ciclos e

Grupo 4: submetido a 1000 ciclos. 
Terminados os respectivos tratamentos de termociclagem os dentes foram armazenados submersos em solução corante de fucsina a $0,5 \%$, a $37^{\circ} \mathrm{C}$ por 24 horas.

\subsection{Técnica para o Seccionamento dos Dentes}

Após a ciclagem térmica e permanência no corante (fucsina básica), os espécimes foram escovados, lavados e permaneceram em água corrente por aproximadamente 6 horas para eliminação do excesso do corante e, depois, deixados a secar por um período igual em condições ambientes. Depois de completamente secos, a película de esmalte foi removida por raspagem e os dentes foram incluídos em um cilindro de resina poliestirênica (Resapol T208 - Difibra/Fiberglass Ltda., SP/Brasil), obtidos a partir de um molde pré-fabricado de silicona, com medidas apropriadas para adaptação na máquina de seccionamento de tecidos duros (EXTEC-“Division of Excel Tecnologies INC-Model 1010. Labcut Low Speed Diamond Saw"). Para a inclusão dos espécimes, a resina acrílica autopolimerizável (Clássico Jet Artigos Odontológicos) foi manipulada e inserida inicialmente em pequenas quantidades no interior das bases, até que fossem totalmente preenchidas. (Figura 4.7)

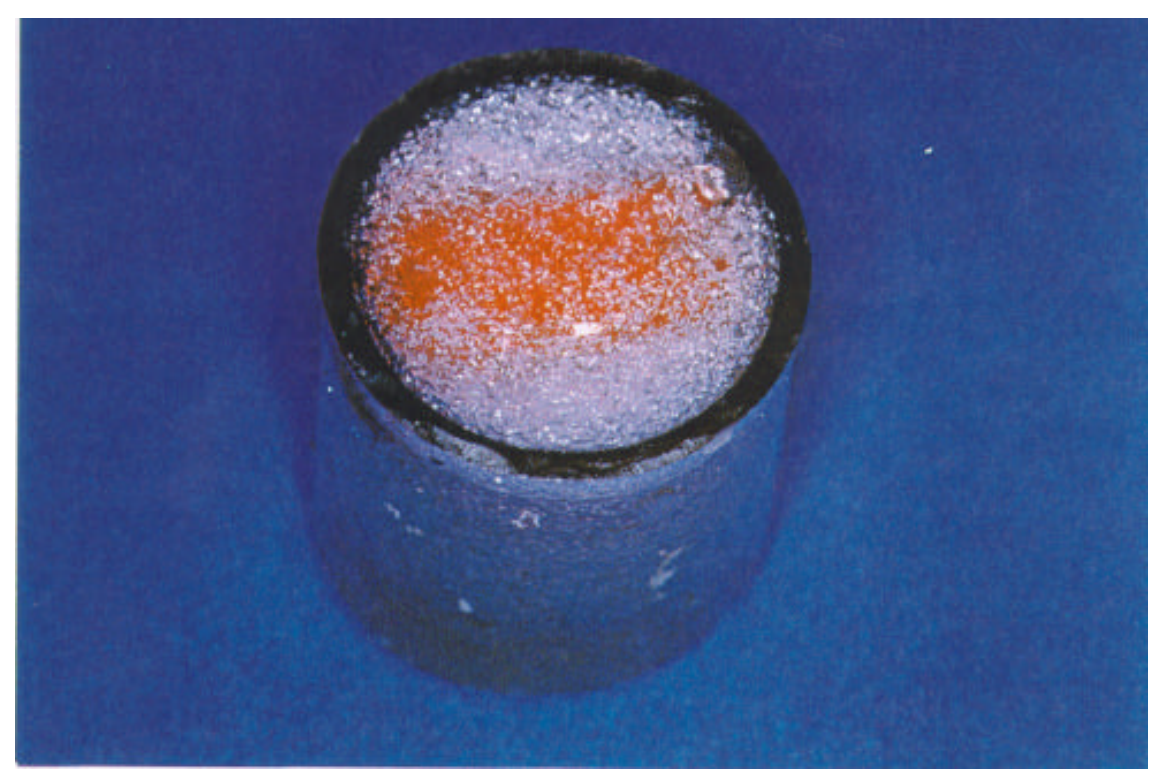

FIGURA 4.7. Espécime incluído no interior da base de resina. 
O conjunto foi preso à haste móvel do aparelho, e os dentes seccionados em cortes de aproximadamente $0,5 \mathrm{~mm}$, no sentido vestíbulolingual com disco diamantado montado na outra extremidade do aparelho a uma velocidade de 300 r.p.m., sempre refrigerado por um reservatório do próprio aparelho contendo água e óleo fornecido pelo fabricante. Para cada dente foram obtidas aproximadamente 4 secções.(Figura 4.8)

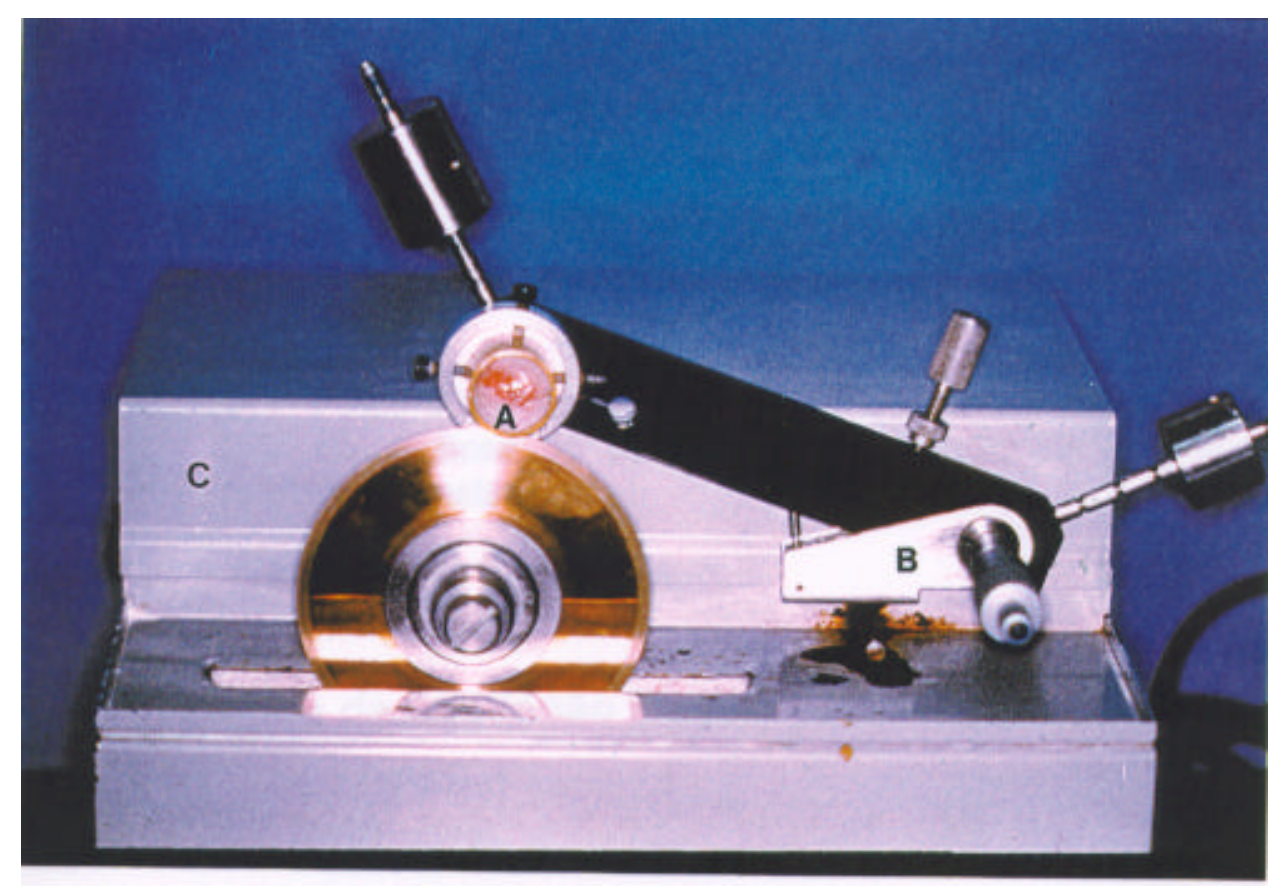

FIGURA 4.8. Espécime (A) adaptado a haste movél (B) da máquina de corte (C).

Depois de seccionados os dentes, as secções foram colocadas em contato com papel absorvente durante 30 minutos, para que a umidade fosse removida.(Figura 4.9) 


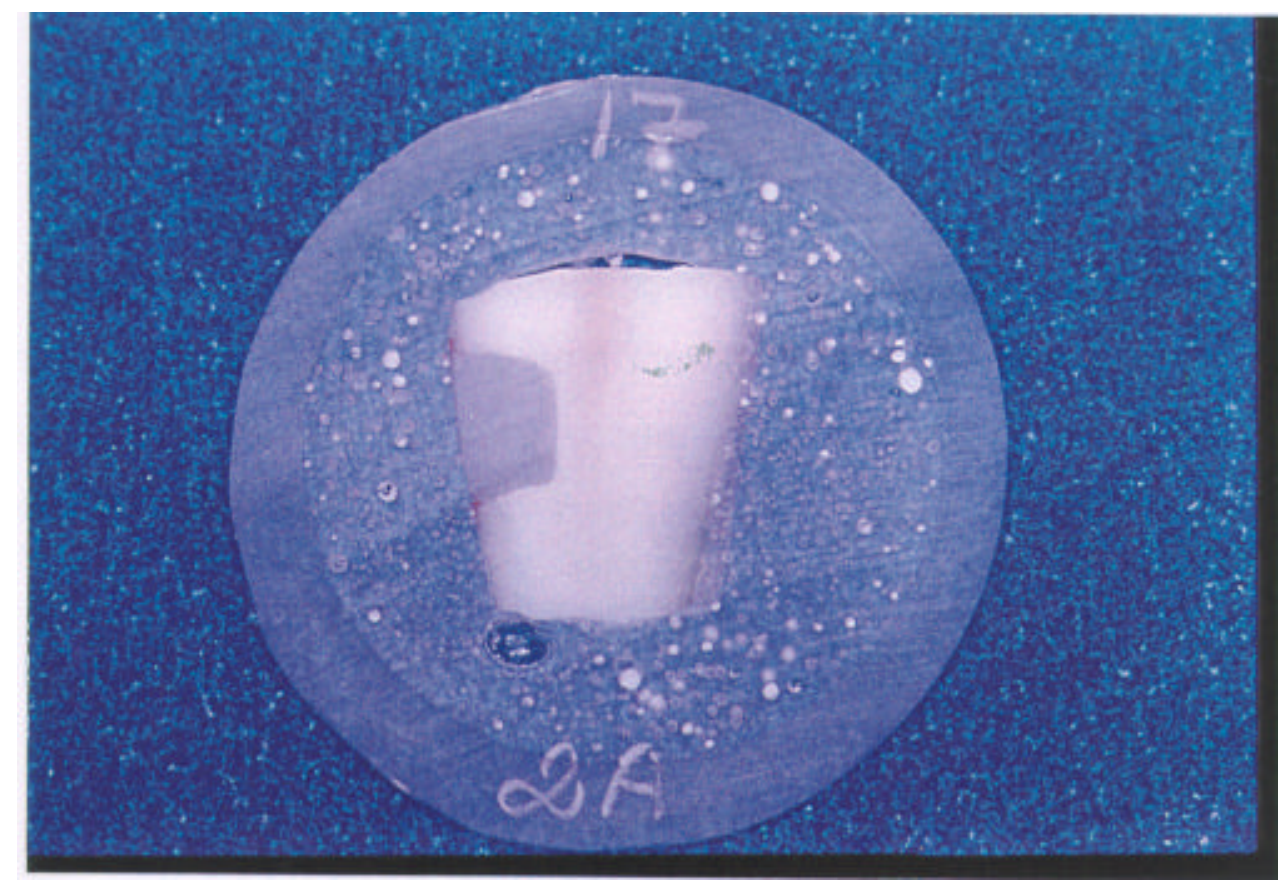

FIGURA 4.9. Fotografia ilustrativa do corte obtido para avaliação dos índices de penetração do corante na interface dente/restauração.

\subsection{Métodos de Avaliação da Microinfiltração}

\subsubsection{Método Qualitativo}

Para este método de avaliação as secções foram analisadas em microscópio com 40 vezes de aumento por dois examinadores calibrados e foram classificadas de acordo com o grau de penetração do corante (fucsina básica a $0,5 \%$ ). Todas as secções foram analisadas para que se pudesse comparar metodologias de avaliação de infiltração marginal que utilizam apenas a secção que obtêm o grau máximo de infiltração para cada espécime e as que utilizam a média de infiltração para cada espécime.

O grau de infiltração foi atribuído empregando-se o critério de escores modificados $8,35,38,39,53,87,89,116,126,142,145,202$ (Figura 4.10) com os seguintes valores de infiltração:

$$
\begin{array}{ll}
0= & \text { nenhuma infiltração } \\
1= & \text { infiltração até a metade da parede circundante }
\end{array}
$$


$2=\quad$ infiltração em toda a parede circundante

$3=\quad$ infiltração na parede circundante e axial

4= infiltração na parede circundante, axial e em direção à polpa.

Após as avaliações independentes de cada examinador, os índices foram confrontados. Em caso de discordância entre os resultados, uma nova avaliação foi realizada para se chegar a um resultado que fosse de consenso dos dois avaliadores. 

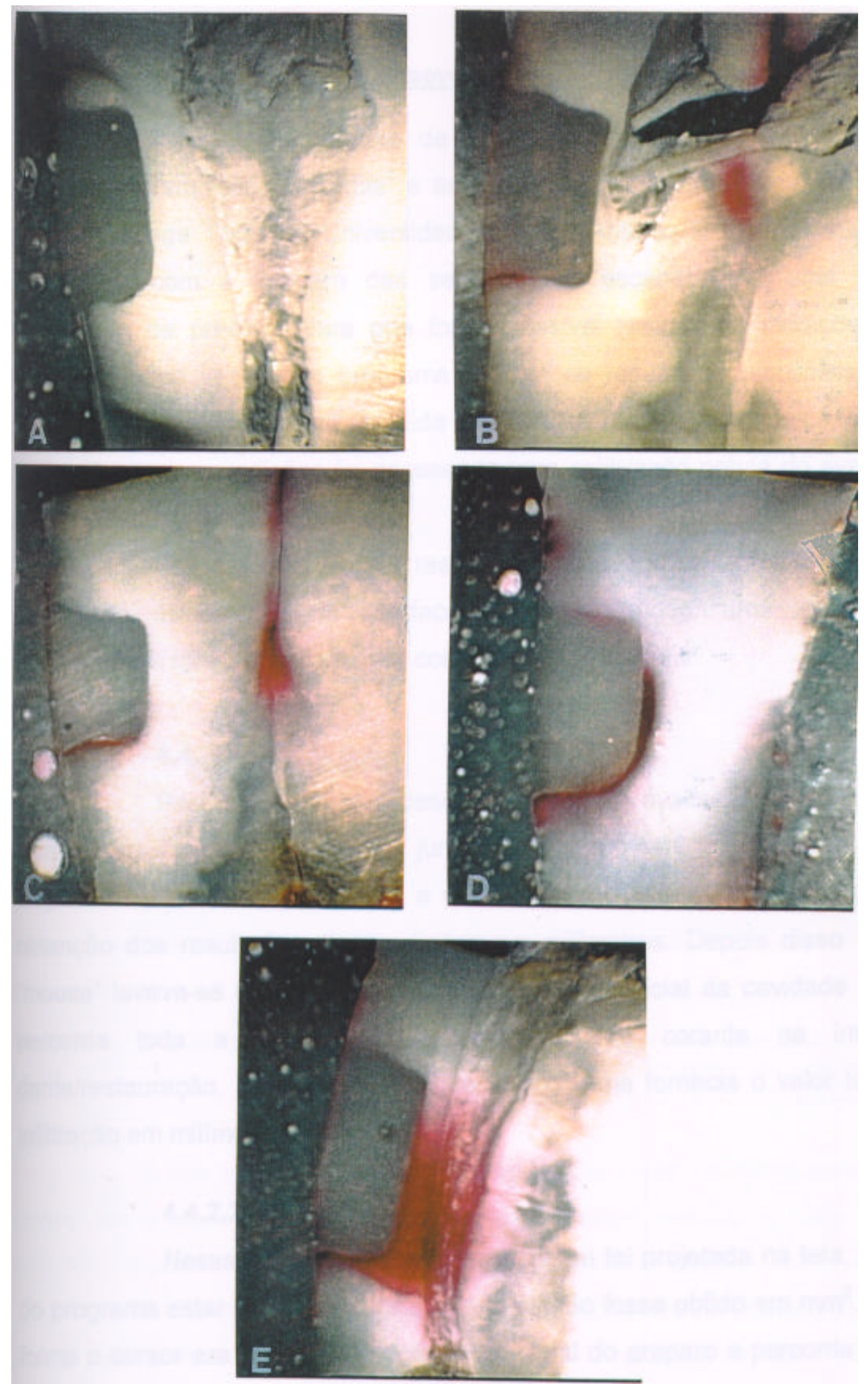

FIGURA 4.10. (A)- Grau 0 de infiltração marginal; (B)- Grau 1 de infiltração marginal; (C)- Grau 2 de infiltração marginal; (D) - Grau 3 de infiltração marginal; (E)- Grau 4 de infiltração marginal. 


\subsubsection{Métodos Quantitativos}

Para estes métodos de avaliação, as secções de todos os espécimes foram "escanerizadas" e as imagens obtidas foram analisadas no programa Image Tools da Universidade de San Antonio-Texas (UTHSCSH). Juntamente com a imagem das secções foi "escanerizada" uma régua milimetrada de precisão para que fosse possível realizar as medições em milímetros, uma vez que o programa fornece os resultados em pixels, mas permite a conversão desta medida em várias outras unidades. Para a realização destas medições foi necessário uma calibração prévia do avaliador no que se refere à acuidade visual.

Dessa forma, foram realizadas duas análises quantitativas da penetração do corante na interface dente/restauração, uma linear com resultados em $\mathrm{mm}$ e outra em área com resultados $\mathrm{em} \mathrm{mm}^{2}$.

\subsubsection{Medida linear}

Para a realização desse método de avaliação de infiltração marginal, a imagem da secção juntamente com a régua milimetrada foi projetada na tela do computador, e por meio do programa, calibrado para a obtenção dos resultados das medições em milímetros. Depois disso com o "mouse" levava-se o cursor até o ângulo cavo-superficial da cavidade e este percorria toda a extensão de penetração do corante na interface dente/restauração. Ao final da medição, o programa fornecia o valor total da infiltração em milímetros.

\subsubsection{Medida em área}

Nessa avaliação, a imagem também foi projetada na tela, depois do programa estar calibrado para que o resultado fosse obtido em $\mathrm{mm}^{2}$, dessa forma o cursor era levado até o cavo-superficial do preparo e percorria toda a área nítida de penetração do corante. Ao final da demarcação da penetração do corante o programa fornecia a área total de infiltração.

Também para esses dois métodos quantitativos foram utilizados, de cada espécime, a secção que obteve o grau máximo de infiltração e a média 
da infiltração de todas as secções para que se pudesse comparar essas duas metodologias de avaliação.

É importante salientar que os espécimes onde o corante penetrou pela margem descoberta ao redor das restaurações $(1 \mathrm{~mm})$ e não pela interface dente/restauração, foram considerados como infiltração zero.(Figura 4.11)

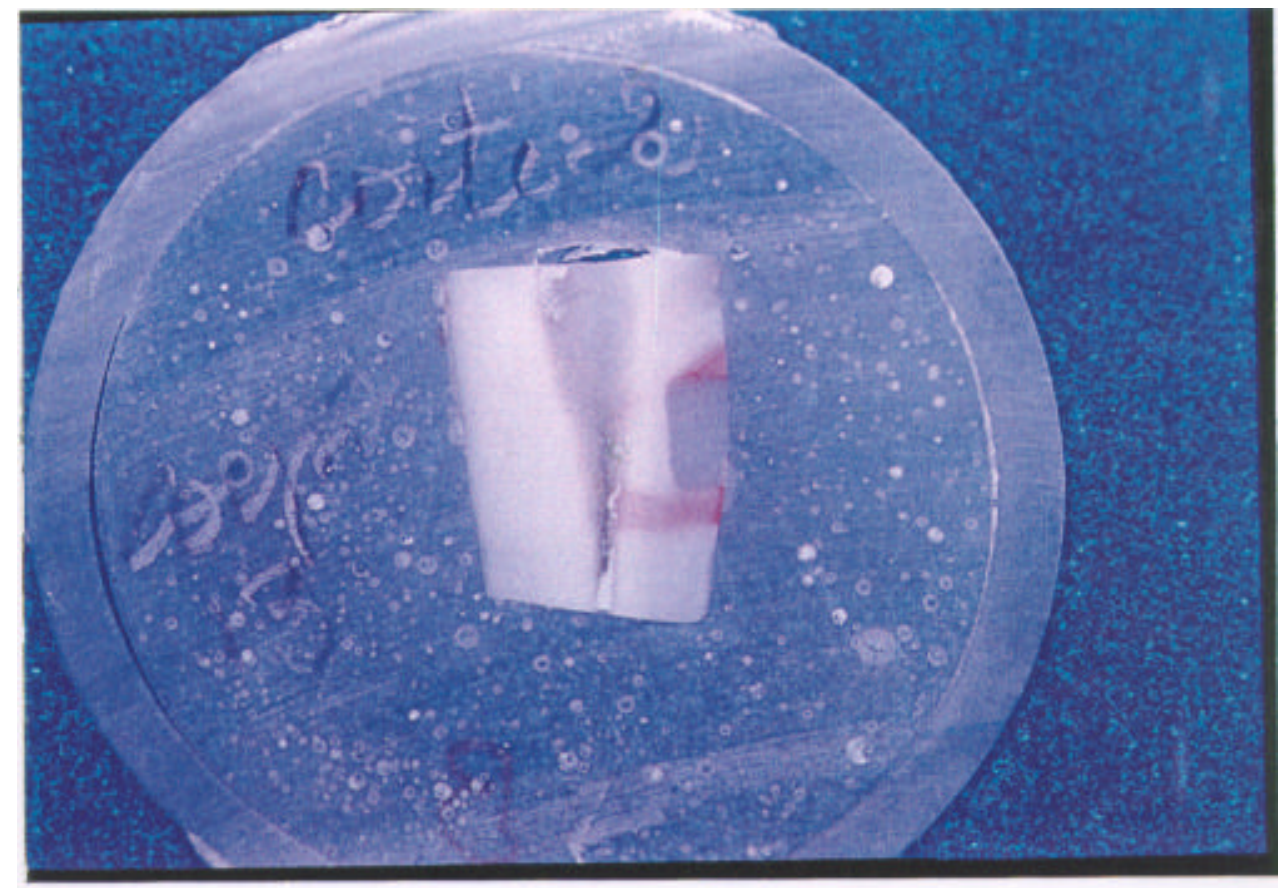

FIGURA 4.11. Aspecto fotográfico de um espécime com infiltração do corante pela margem descoberta ao redor da restauração. Considerado como Grau 0 de infiltração.

$E$ nos cortes onde a infiltração ocorreu nas margens oclusal e gengival da mesma cavidade, as medições foram realizadas nas duas interfaces, mas os resultados considerados de uma única secção.

Em uma segunda etapa deste trabalho, tentou-se utilizar um outro corante para demonstrar a infiltração marginal, o azul de metileno à $2 \%$, mantendo-se fixas as outras variáveis. Devido a impossibilidade de determinar os índices de infiltração marginal pela ocorrência de grande quantidade de corante na interface dente/restauração, essa etapa não foi considerada no presente trabalho e será discutida mais adiante. 
Os resultados obtidos foram analisados pelos testes estatísticos de Kruskall-Wallis para comparar os graus de penetração do corante dos quatro grupos em relação às seis medidas obtidas e pelo Coeficiente de correlação de Spearman para verificar a correlação entre os métodos de leitura do grau de penetração do corante. 
5 - RESULTADOS 


\section{5- Resultados}

Os índices individuais do grau de penetração do corante atribuídos aos quatro grupos testados, associados aos diferentes métodos de leitura estão dispostos nas Tabelas I, II, III e IV.

TABELA I- Valores médios e máximos de penetração do corante, obtido por meio de leitura por escores, medida linear e área atribuídos a cada um dos espécimes do Grupo 1 (não submetido à ciclagem térmica).

\begin{tabular}{c|c|c|c|c|c|c}
\hline Espécime & \multicolumn{3}{|c|}{ Valor Médio } & \multicolumn{3}{c}{ Valor Máximo } \\
\hline & $\begin{array}{c}\text { Escores } \\
(\mathbf{0} \text { a 4) }\end{array}$ & $\begin{array}{c}\text { Area } \\
\left(\mathbf{m ~ m}^{2}\right)\end{array}$ & $\begin{array}{c}\text { Linear } \\
(\mathbf{m m})\end{array}$ & $\begin{array}{c}\text { Escores } \\
(\mathbf{0} \mathbf{~ a ~ 4})\end{array}$ & $\begin{array}{c}\text { Área } \\
\left(\mathbf{m ~ m}^{2}\right)\end{array}$ & $\begin{array}{c}\text { Linear } \\
(\mathbf{m m})\end{array}$ \\
\hline $\mathbf{1}$ & 0.84 & 0.055 & 0.34 & 1 & 0.15 & 0.88 \\
\hline $\mathbf{2}$ & 0 & 0 & 0 & 0 & 0 & 0 \\
\hline $\mathbf{3}$ & 0 & 0 & 0 & 0 & 0 & 0 \\
\hline $\mathbf{4}$ & 0.84 & 0.0008 & 0.01 & 1 & 0.01 & 0.17 \\
\hline $\mathbf{5}$ & 0 & 0 & 0 & 0 & 0 & 0 \\
\hline $\mathbf{6}$ & 0.34 & 0.0125 & 0.08 & 1 & 0.07 & 0.39 \\
\hline $\mathbf{7}$ & 0 & 0 & 0 & 0 & 0 & 0 \\
\hline $\mathbf{8}$ & 0 & 0 & 0 & 0 & 0 & 0 \\
\hline $\mathbf{9}$ & 0.67 & 0.03 & 0.29 & 2 & 0.13 & 0.89 \\
\hline $\mathbf{1 0}$ & 0 & 0 & 0 & 0 & 0 & 0 \\
\hline $\mathbf{1 1}$ & 0.5 & 0.0175 & 0.13 & 1 & 0.05 & 0.46 \\
\hline $\mathbf{1 2}$ & 0.5 & 0.0175 & 0.16 & 1 & 0.07 & 0.54 \\
\hline $\mathbf{1 3}$ & 0 & 0 & 0 & 0 & 0 & 0 \\
\hline $\mathbf{1 4}$ & 0.25 & 0.0113 & 0.09 & 1 & 0.05 & 0.37 \\
\hline $\mathbf{1 5}$ & 0 & 0 & 0 & 0 & 0 & 0 \\
\hline $\mathbf{1 6}$ & 0.125 & 0.005 & 0.03 & 1 & 0.04 & 0.26 \\
\hline $\mathbf{1 7}$ & 0 & 0 & 0 & 0 & 0 & 0 \\
\hline $\mathbf{1 8}$ & 0.84 & 0.028 & 0.17 & 2 & 0.18 & 1.10 \\
\hline $\mathbf{1 9}$ & 0 & 0 & 0 & 0 & 0 & 0 \\
\hline Média & 0,218 & 0,009 & 0,068 & 0,580 & 0,039 & 0,266 \\
\hline $\mathbf{D . P .}$ & 0,303 & 0,015 & 0,105 & 0,692 & 0,057 & 0,359 \\
\hline Mediana & 0,000 & 0,000 & 0,000 & 0,000 & 0,000 & 0,000 \\
\hline & & & & & & \\
\hline & & & & & & \\
\hline
\end{tabular}


TABELA II- Valores médios e máximos de penetração do corante, obtido por meio de leitura por escores, medida linear e área atribuídos a cada um dos espécimes do Grupo 2 (submetido à ciclagem térmica - 100 ciclos).

\begin{tabular}{|c|c|c|c|c|c|c|}
\hline Espécime & & lor Méc & & & or Máxi & \\
\hline & $\begin{array}{l}\text { Escores } \\
(0 \text { a } 4)\end{array}$ & $\begin{array}{c}\text { Área } \\
\left(\mathrm{mm}^{2}\right)\end{array}$ & $\begin{array}{c}\begin{array}{c}\text { Linear } \\
(\mathrm{mm})\end{array}\end{array}$ & $\begin{array}{c}\text { Escores } \\
(0 \text { a } 4)\end{array}$ & $\begin{array}{c}\text { Área } \\
\left(\mathrm{mm}^{2}\right)\end{array}$ & $\begin{array}{c}\text { Linear } \\
(\mathrm{mm})\end{array}$ \\
\hline 1 & 1.34 & 0.995 & 2.17 & 4 & 4.72 & 5.18 \\
\hline 2 & 1.67 & 0.67 & 1.64 & 4 & 3.45 & 4.56 \\
\hline 3 & 0.57 & 0.037 & 0.28 & 3 & 0.14 & 1.11 \\
\hline 4 & 0 & 0 & 0 & 0 & 0 & 0 \\
\hline 5 & 1.67 & 0.235 & 0.91 & 4 & 1.16 & 3.97 \\
\hline 6 & 2 & 0.79 & 1.34 & 4 & 2.69 & 3.05 \\
\hline 7 & 0 & 0 & 0 & 0 & 0 & 0 \\
\hline 8 & 0 & 0 & 0 & 0 & 0 & 0 \\
\hline 9 & 0.25 & 0.01 & 0.18 & 1 & 0.05 & 0.62 \\
\hline 10 & 0 & 0 & 0 & 0 & 0 & 0 \\
\hline 11 & 0 & 0 & 0 & 0 & 0 & 0 \\
\hline 12 & 0 & 0 & 0 & 0 & 0 & 0 \\
\hline 13 & 0 & 0 & 0 & 0 & 0 & 0 \\
\hline 14 & 1.75 & 0.57 & 1.36 & 4 & 2.32 & 3.4 \\
\hline 15 & 0 & 0 & 0 & 0 & 0 & 0 \\
\hline 16 & 0 & 0 & 0 & 0 & 0 & 0 \\
\hline 17 & 0 & 0 & 0 & 0 & 0 & 0 \\
\hline 18 & 0.4 & 0.017 & 0.29 & 2 & 0.08 & 1.81 \\
\hline 19 & 0 & 0 & 0 & 0 & 0 & 0 \\
\hline Média & 0,508 & 0,175 & 0,430 & 1,368 & 0,769 & 1,247 \\
\hline D. P. & 0,748 & 0,322 & 0,689 & 1,801 & 1,432 & 1,819 \\
\hline Mediana & 0,000 & 0,000 & 0,000 & 0,000 & 0,000 & 0,000 \\
\hline
\end{tabular}


TABELA III- Valores médios e máximos de penetração do corante, obtido por meio de leitura por escores, medida linear e área atribuídos a cada um dos espécimes do Grupo 3 (submetido à ciclagem térmica - 200 ciclos).

\begin{tabular}{c|c|c|c|c|c|c}
\hline Espécime & \multicolumn{3}{|c|}{ Valor Médio } & \multicolumn{3}{c}{ Valor Máximo } \\
\hline & $\begin{array}{c}\text { Escores } \\
(\mathbf{0} \mathbf{~} \mathbf{4})\end{array}$ & $\begin{array}{c}\text { Área } \\
\left(\mathbf{m m}^{\mathbf{2}}\right)\end{array}$ & $\begin{array}{c}\text { Linear } \\
(\mathbf{m m})\end{array}$ & $\begin{array}{c}\text { Escores } \\
(\mathbf{0} \mathbf{~ a ~})\end{array}$ & $\begin{array}{c}\text { Área } \\
\left(\mathbf{m m}^{\mathbf{2}} \mathbf{)}\right.\end{array}$ & $\begin{array}{c}\text { Linear } \\
(\mathbf{m m})\end{array}$ \\
\hline $\mathbf{1}$ & 0 & 0 & 0 & 0 & 0 & 0 \\
\hline $\mathbf{2}$ & 0.25 & 0.014 & 0.07 & 1 & 0.09 & 0.32 \\
\hline $\mathbf{3}$ & 0 & 0 & 0 & 0 & 0 & 0 \\
\hline $\mathbf{4}$ & 0 & 0 & 0 & 0 & 0 & 0 \\
\hline $\mathbf{5}$ & 1 & 0.06 & 0.61 & 4 & 0.21 & 1.84 \\
\hline $\mathbf{6}$ & 0 & 0 & 0 & 0 & 0 & 0 \\
\hline $\mathbf{7}$ & 0 & 0 & 0 & 0 & 0 & 0 \\
\hline $\mathbf{8}$ & 0 & 0 & 0 & 0 & 0 & 0 \\
\hline $\mathbf{9}$ & 0.5 & 0.021 & 0.21 & 2 & 0.13 & 1.01 \\
\hline $\mathbf{1 0}$ & 0 & 0 & 0 & 0 & 0 & 0 \\
\hline $\mathbf{1 1}$ & 0 & 0 & 0 & 0 & 0 & 0 \\
\hline $\mathbf{1 2}$ & 1.81 & 0.83 & 1.63 & 4 & 4.17 & 4.06 \\
\hline $\mathbf{1 3}$ & 0.17 & 0.0075 & 0.03 & 1 & 0.06 & 0.21 \\
\hline $\mathbf{1 4}$ & 1 & 0.0375 & 0.28 & 2 & 0.14 & 1.11 \\
\hline $\mathbf{1 5}$ & 0.84 & 0.024 & 0.20 & 1 & 0.07 & 0.50 \\
\hline $\mathbf{1 6}$ & 1 & 0.0525 & 0.32 & 2 & 0.11 & 0.79 \\
\hline $\mathbf{1 7}$ & 0.91 & 0.034 & 0.22 & 1 & 0.07 & 0.32 \\
\hline $\mathbf{1 8}$ & 2.84 & 0.47 & 1.27 & 4 & 1.48 & 1.97 \\
\hline $\mathbf{1 9}$ & 1 & 0.064 & 0.50 & 2 & 0.09 & 0.88 \\
\hline Média & 0,596 & 0,085 & 0,281 & 1,263 & 0,348 & 0,684 \\
\hline $\mathbf{D . P}$ & 0,763 & 0,209 & 0,454 & 1,447 & 0,983 & 1,027 \\
\hline Mediana & 0,250 & 0,014 & 0,070 & 1,000 & 0,070 & 0,320 \\
\hline & & & & & & \\
\hline
\end{tabular}


TABELA IV- Valores médios e máximos de penetração do corante, obtido por meio de leitura por escores, medida linear e área atribuídos a cada um dos espécimes do Grupo 4 (submetido à ciclagem térmica - 1000 ciclos).

\begin{tabular}{c|c|c|c|c|c|c}
\hline Espécime & \multicolumn{3}{|c|}{ Valor Médio } & \multicolumn{3}{c}{ Valor Máximo } \\
\hline & $\begin{array}{c}\text { Escores } \\
(\mathbf{0} \mathbf{~} \mathbf{4})\end{array}$ & $\begin{array}{c}\text { Área } \\
\left(\mathbf{m m}^{\mathbf{2}}\right)\end{array}$ & $\begin{array}{c}\text { Linear } \\
(\mathbf{m m})\end{array}$ & $\begin{array}{c}\text { Escores } \\
(\mathbf{0} \mathbf{~ a ~} \mathbf{)}\end{array}$ & $\begin{array}{c}\text { Área } \\
\left(\mathbf{m m}^{\mathbf{2}}\right)\end{array}$ & $\begin{array}{c}\text { Linear } \\
(\mathbf{m m})\end{array}$ \\
\hline $\mathbf{1}$ & 0 & 0 & 0 & 0 & 0 & 0 \\
\hline $\mathbf{2}$ & 0 & 0 & 0 & 0 & 0 & 0 \\
\hline $\mathbf{3}$ & 0.92 & 0.08 & 0.48 & 3 & 0.28 & 1.43 \\
\hline $\mathbf{4}$ & 0 & 0 & 0 & 0 & 0 & 0 \\
\hline $\mathbf{5}$ & 0 & 0 & 0 & 0 & 0 & 0 \\
\hline $\mathbf{6}$ & 0 & 0 & 0 & 0 & 0 & 0 \\
\hline $\mathbf{7}$ & 1.75 & 0.435 & 1.43 & 4 & 1.62 & 4.24 \\
\hline $\mathbf{8}$ & 0 & 0 & 0 & 0 & 0 & 0 \\
\hline $\mathbf{9}$ & 0.84 & 0.10 & 0.62 & 2 & 0.33 & 1.66 \\
\hline $\mathbf{1 0}$ & 0.17 & 0.011 & 0.05 & 1 & 0.10 & 0.33 \\
\hline $\mathbf{1 1}$ & 0.375 & 0.009 & 0.10 & 1 & 0.03 & 0.41 \\
\hline $\mathbf{1 2}$ & 0.25 & 0.005 & 0.05 & 1 & 0.02 & 0.23 \\
\hline $\mathbf{1 3}$ & 1.08 & 0.14 & 0.73 & 4 & 0.87 & 3.85 \\
\hline $\mathbf{1 4}$ & 2.4 & 0.18 & 1.16 & 4 & 0.32 & 2.15 \\
\hline $\mathbf{1 5}$ & 0.75 & 0.054 & 0.39 & 2 & 0.14 & 1.11 \\
\hline $\mathbf{1 6}$ & 0.67 & 0.125 & 0.45 & 2 & 0.51 & 1.16 \\
\hline $\mathbf{1 7}$ & 0 & 0 & 0 & 0 & 0 & 0 \\
\hline $\mathbf{1 8}$ & 0.84 & 0.05 & 0.20 & 2 & 0.17 & 1.55 \\
\hline $\mathbf{1 9}$ & 0.25 & 0.0058 & 0.08 & 1 & 0.03 & 0.34 \\
\hline Média & 0,542 & 0,063 & 0,302 & 1,421 & 0,232 & 0,971 \\
\hline $\mathbf{D . ~ P .}$ & 0,665 & 0,106 & 0,423 & 1,465 & 0,405 & 1,285 \\
\hline Mediana & 0,250 & 0,009 & 0,080 & 1,000 & 0,030 & 0,340 \\
\hline & & & & & & \\
\hline
\end{tabular}

Para facilitar a comparação entre os valores obtidos nos métodos de leitura da penetração do corante, os dados foram agrupados, como vistos nas Figuras I, II e III (médias dos valores médios) e Figuras IV, V e VI (médias dos valores máximos). 
FIGURA I- Comparação das médias dos valores médios de penetração do corante, obtidos por meio da leitura por escores dos Grupos 1 (sem ciclagem), 2 (100 ciclos), 3 (200 ciclos) e 4 (1000 ciclos).

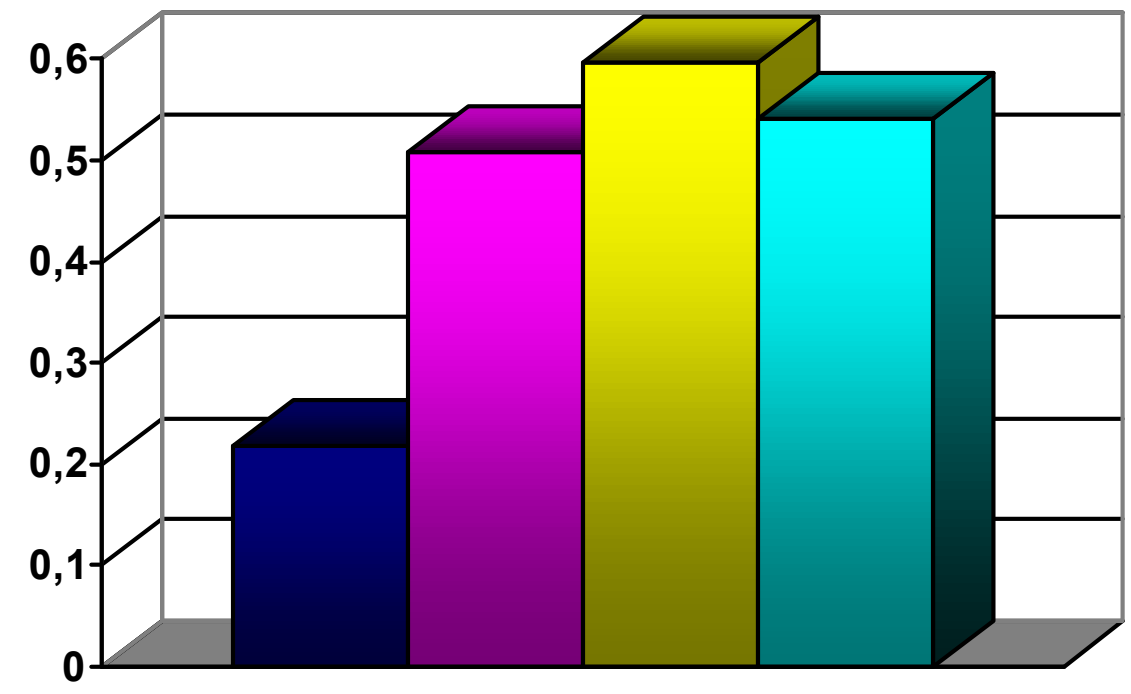

\begin{tabular}{|l|}
\hline Grupo 1 \\
$\square$ Grupo 2 \\
$\square$ Grupo 3 \\
$\square$ Grupo 4
\end{tabular}

FIGURA II- Comparação das médias dos valores médios de penetração do corante, obtidos por meio da leitura da medida linear dos Grupos 1 (sem ciclagem), 2 (100 ciclos), 3 (200 ciclos) e 4 (1000 ciclos).

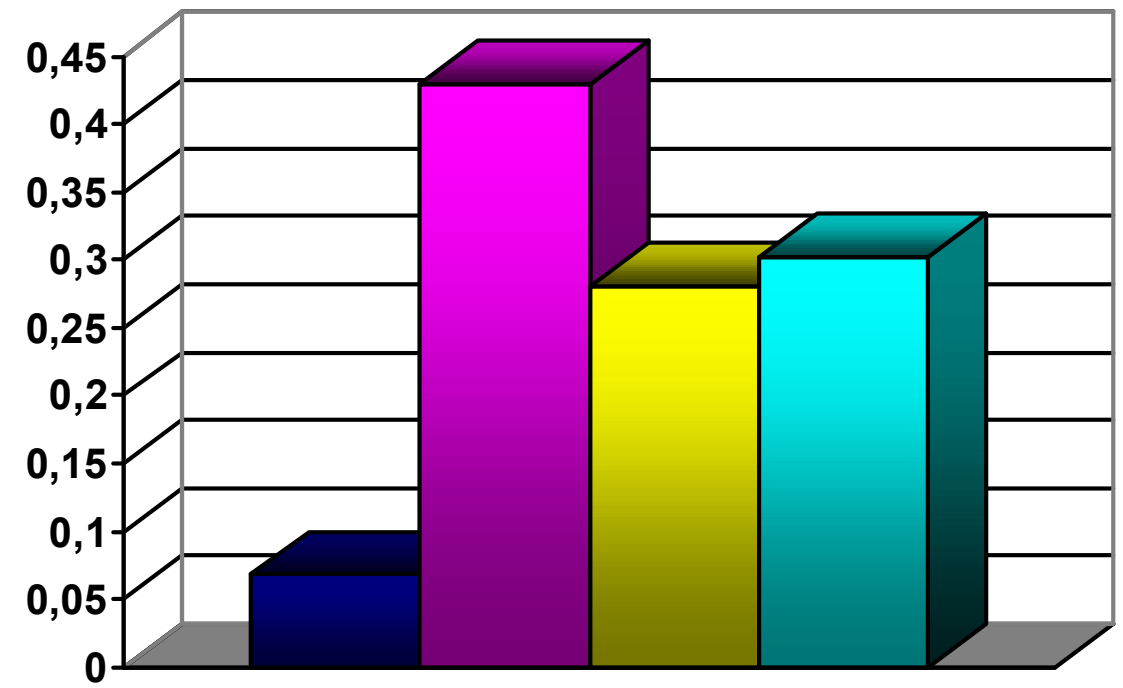

Grupo 1

$\square$ Grupo 2

$\square$ Grupo 3

$\square$ Grupo 4 
FIGURA III- Comparação das médias dos valores médios de penetração do corante, obtidos por meio da leitura da área dos Grupos 1 (sem ciclagem), 2 (100 ciclos), 3 (200 ciclos) e 4 (1000 ciclos).

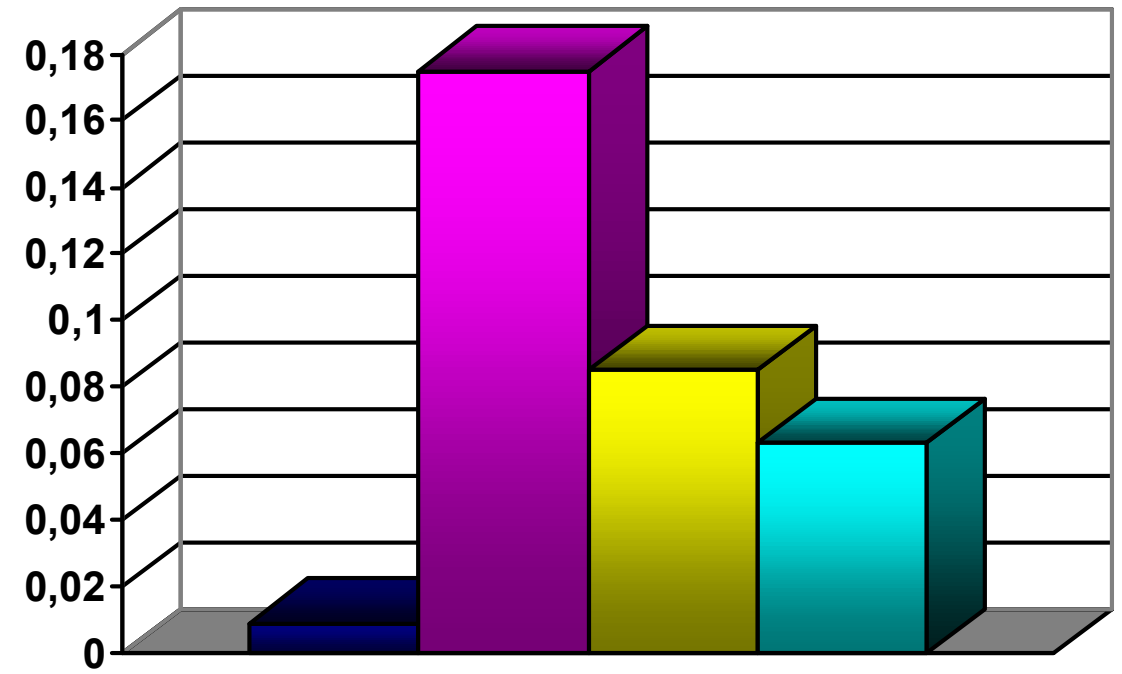

Grupo 1

$\square$ Grupo 2

$\square$ Grupo 3

$\square$ Grupo 4

FIGURA IV- Comparação das médias dos valores máximos de penetração do corante, obtidos por meio da leitura por escores dos Grupos 1 (sem ciclagem), 2 (100 ciclos), 3 (200 ciclos) e 4 (1000 ciclos).

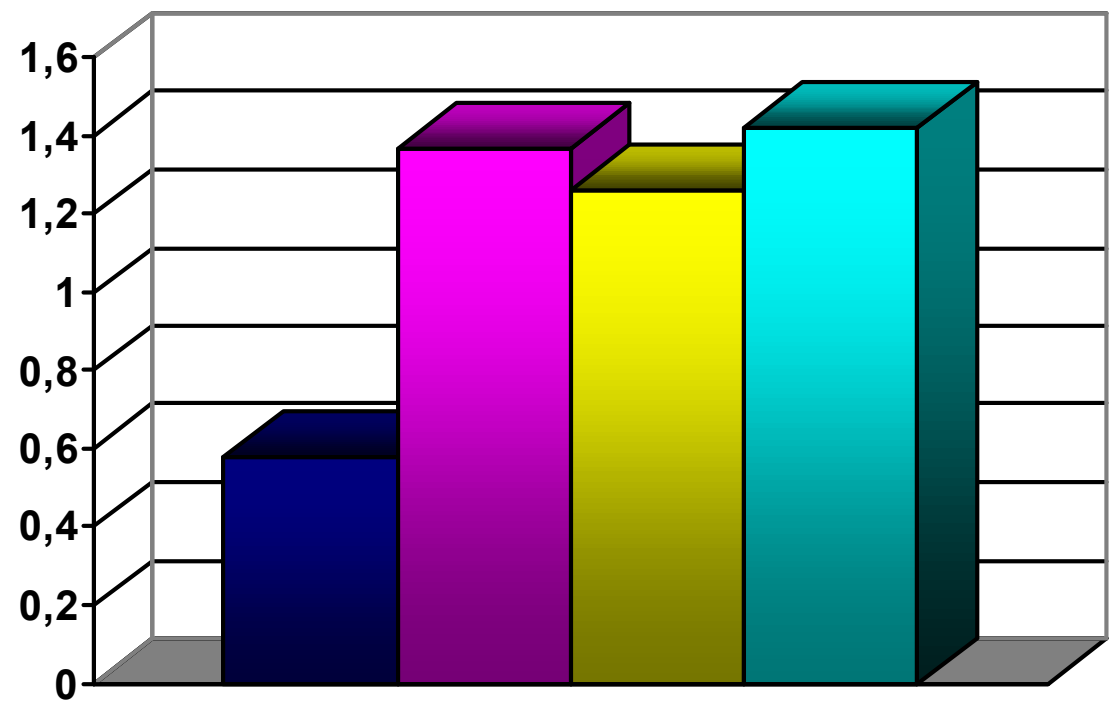

$\square$ Grupo 1
$\square$ Grupo 2
$\square$ Grupo 3
$\square$ Grupo 4 
FIGURA V- Comparação das médias dos valores máximos de penetração do corante, obtidos por meio da leitura linear dos Grupos 1 (sem ciclagem), 2 (100 ciclos), 3 (200 ciclos) e 4 (1000 ciclos).

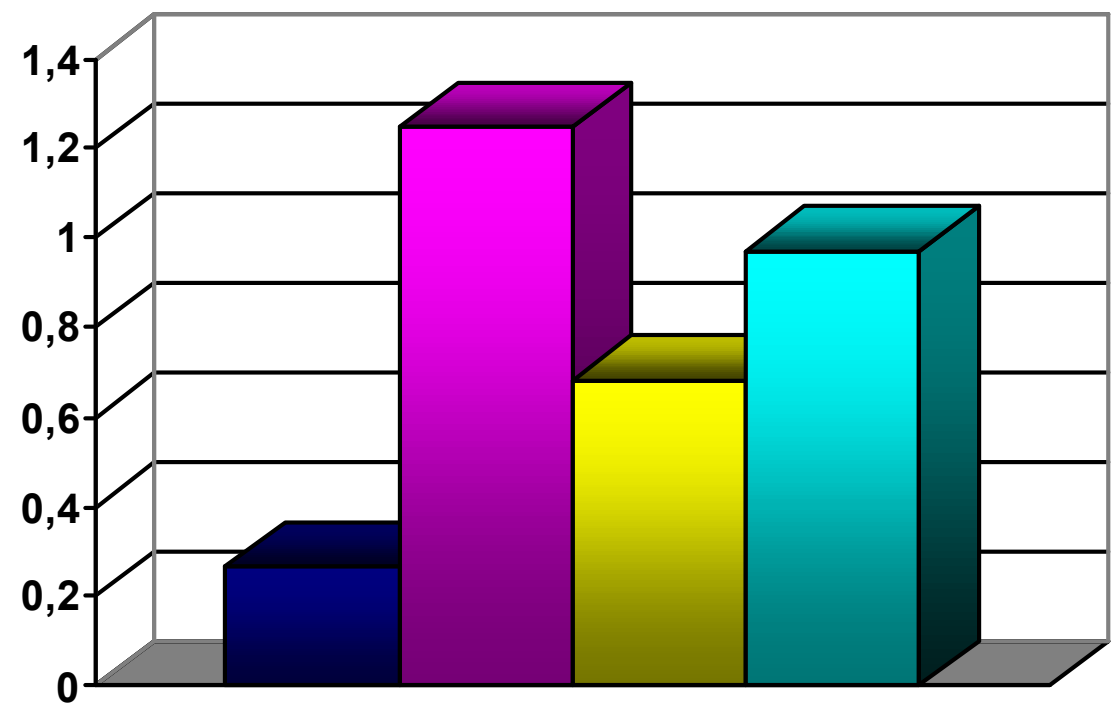

Grupo 1

$\square$ Grupo 2

$\square$ Grupo 3

$\square$ Grupo 4

FIGURA VI- Comparação das médias dos valores máximos de penetração do corante, obtidos por meio da leitura da área dos Grupos 1 (sem ciclagem), 2 (100 ciclos), 3 (200 ciclos) e 4 (1000 ciclos).

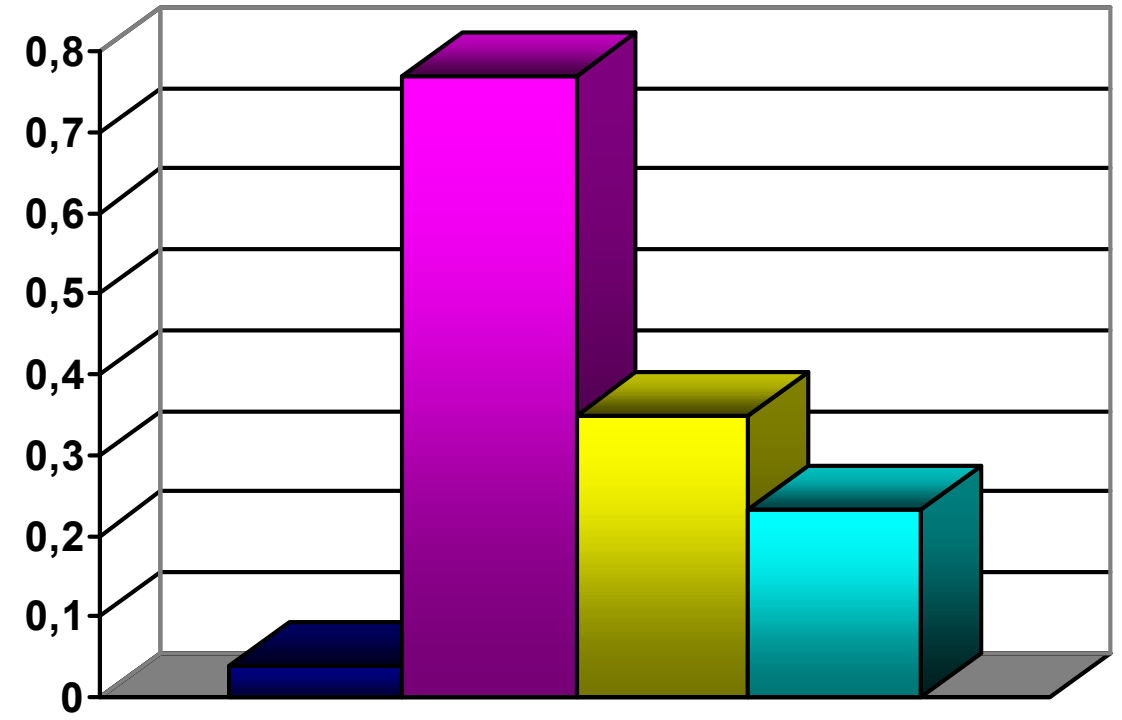


Com a finalidade de comparar os graus de penetração do corante dos quatro grupos em relação às seis medidas obtidas nas Tabelas I, II, III e IV, foi aplicado o teste não paramétrico de Kruskall-Wallis (Tabela V).

TABELA V- Teste de Kruskall-Wallis para comparação entre os quatro grupos de ciclagem em relação às seis medidas realizadas.

\begin{tabular}{c|c|c|c}
\hline MEDIDA & H & $\mathbf{P}$ & \\
\hline Média Escores & 2,95 & 0,399 & n.s. \\
Média Linear & 2,78 & 0,426 & n.s. \\
Média Área & 2,66 & 0,448 & n.s. \\
Máxima Escores & 2,83 & 0,418 & n.s. \\
Máxima Linear & 2,67 & 0,445 & n.s. \\
Máxima Área & 2,56 & 0,463 & n.s. \\
\hline
\end{tabular}

n.s. - diferenças não estatisticamente significante

Com base nos resultados obtidos, apesar do Grupo I apresentar um menor índice numérico de penetração de corante em relação aos outros grupos testados, esta diferença não mostrou-se estatisticamente significante ao nível de significância de 5\%.

Para se verificar a correlação entre os métodos de leitura do grau de penetração do corante (escores, linear e área), foi calculado o coeficiente de correlação de Spearman (Tabela VI).

TABELA VI- Coeficiente de correlação de Spearman entre os métodos de leitura de penetração do corante.

\begin{tabular}{l|c|c}
\hline \multicolumn{1}{c|}{ COMPARAÇÃO } & R & P \\
\hline Média Escores X Média Área & 0,989 & $<0,001^{*}$ \\
Média Escores X Média Linear & 0,986 & $<0,001^{*}$ \\
Média Área X Média Linear & 0,994 & $<0,001^{*}$ \\
Máxima Escores X Máxima Área & 0,980 & $<0,001^{*}$ \\
Máxima Escores X Máxima Linear & 0,984 & $<0,001^{*}$ \\
Máxima Área X Máxima Linear & 0,986 & $<0,001^{*}$ \\
\hline
\end{tabular}

* correlação estatisticamente significante. 
Analisando a Tabela VI, observa-se uma forte correlação entre os métodos de leitura de penetração do corante, ou seja, os métodos têm uma tendência a se equivalerem, significando que os métodos de leitura de penetração do corante utilizados neste trabalho podem ser comparados entre si. 
6 - DISCUSSÃO 


\section{6- Discussão}

\subsection{Da Metodologia}

Um dos maiores problemas que a dentística restauradora tem enfrentado é a dificuldade em se conseguir uma adesão perfeita dos materiais restauradores à estrutura dentária ${ }^{95,167,178,191}$, falta de união esta, que resulta na formação de um microespaço entre a restauração e as paredes cavitárias, permitindo $o$ ingresso de saliva e componentes salivares promovendo manchamento marginal, fratura das margens das restaurações, desenvolvimento de cáries secundárias na interface dente/restauração, sensibilidade pós-operatória e patologias pulpares s,3,10,21,23,82,95, 104,151,163,196, $^{1}$. Alguns autores ${ }^{1,44,207}$ relataram que o principal fator causal das inflamações pulpares é a microinfiltração após a inserção dos materiais restauradores. BRÄNNSTRÖM; NYBORG ${ }^{22}$, em 1971, sugeriram como uma possível causa de inflamação pulpar, a ocorrência de infiltração de microorganismos ao redor de restaurações, e comprovaram que sua prevenção poderia eliminar as inflamações pulpares; outros autores ${ }^{20,21,45,146,147,148,149,170,162,191}$ também concordaram com esta afirmação. COX et $a^{45}$, em 1987, demonstraram que os fatores químicos/tóxicos, assim como os ácidos e outros componentes dos materiais restauradores por si só, são menos significantes para a injúria pulpar do que a infiltração bacteriana ao redor das margens das restaurações. Outros estudos $^{1,152}$ também salientaram a importância de bactérias na inflamação pulpar associada às restaurações. De acordo com ALANI; TOH ${ }^{1}$, estas pesquisas suportam 0 fato de que muitas das propriedades irritantes anteriormente associadas unicamente com a ação química dos materiais restauradores, ocorrem primeiramente por infiltração bacteriana.

Clinicamente, a microinfiltração é definida como a passagem indetectável de bactérias, fluídos, moléculas ou íons entre as paredes cavitárias e o material restaurador aplicado ${ }^{104}$. A abertura deste espaço e a atividade bacteriana contribuem para a microinfiltração, e podem levar a cáries recorrentes. O tamanho médio de uma bactéria é de $2 \mu \mathrm{m}$ e portanto, é necessário um espaço de 2 a $20 \mu \mathrm{m}$ para que possa ocorrer a penetração e 
deposição de um filme bacteriano nesta interface. A incidência de cárie requer um espaço de pelo menos 50 $\mathrm{m}$; espaço este detectável por um instrumento manual como a sonda exploradora de extremidade bem afilada. Entretanto este espaço é o menor limite visível para o ser humano e por isto, a dificuldade de se avaliar clinicamente a microinfiltração nesta fase ${ }^{10,82,141}$. Além disso a microinfiltração também contribui para a corrosão, dissolução, ou descoloração de certos materiais restauradores ${ }^{196}$.

Este problema se apresenta com maior gravidade nas resinas compostas principalmente por algumas propriedades inerentes ao material como por exemplo a contração de polimerização, diferenças no coeficiente de expansão térmica do dente e da restauração, a sorpção de água do material restaurador quando exposto ao ambiente oral, qualidade da camada híbrida, técnica de inserção, e 0 fator $C$ de configuração das paredes cavitárias $^{4,18,21,26,88,90,98,103,123,137,163,195,205}$.

A microinfiltração tem sido intensamente investigada por muitos anos por teste "in vivo" ${ }^{69} \mathrm{e}$ "in vitro" 1,8,84,93,104,119,128,153. Em decorrência disto vários métodos para o seu estudo " in vitro" foram desenvolvidos. Entretanto alguns autores ${ }^{48,51,61}$, têm observado que os testes de microinfiltração "in vivo" parecem apresentar resultados menos severos que os realizados "in vitro".

A integridade marginal da interface dente/restauração depende de vários fatores, como o tipo do material restaurador, das propriedades físicas do material, da interação entre os materiais, das propriedades físicas dos tecidos dentários (esmalte, dentina e cemento) e da interação com o ambiente oral ${ }^{170}$. A grande maioria dos estudos "in vitro" $5,10,26,38,47,48,49,50,57,63,68,77,82,94,99,104,134,141,160,169,191,195$ tem demonstrado que a indução de mudanças térmicas às restaurações pode resultar na formação de um espaço entre o material restaurador e o dente, devido à diferença de coeficiente de expanção térmica entre os dois, que promove o rompimento do selamento entre o dente e o material restaurador. Um dos fatores que mais influenciam o coeficiente de expansão térmica é a temperatura e a duração da temperatura a que são expostos os materiais e a estrutura dentária ${ }^{202}$. 0 coeficiente de expansão térmica linear é definido como a mudança em extensão do material quando a temperatura é aumentada ou diminuida. 
Quando se trata do material resina composta, sua diferença na expansão térmica com relação a estrutura dentária induz a um estresse que leva ao rompimento da união entre ele ${ }^{53}$. Quando o coeficiente de expansão térmica linear do material restaurador é significantemente diferente da estrutura dentária, a redução da temperatura gera uma pressão interfacial negativa. Esta ação favorece o ingresso de fluídos orais para dentro das margens. O inverso, quando ocorre o aumento da temperatura, a pressão interfacial também aumenta $\mathrm{e}$, consequentemente os fluídos são forçados para fora dessa interface. O resultado de grandes diferenças no coeficiente de expansão térmico linear é uma grande mudança na pressão interna da superfície e como conseqüência, estudos sugerem uma relação definitiva entre este coeficiente e o grau de microinfiltração ${ }^{26}$.

A ciclagem térmica, definida como o processo "in vitro" de submeter dentes e restaurações a temperaturas extremas conforme aquelas encontradas na cavidade oral, é bastante utilizada para estes testes ${ }^{10,77,170}$. Segundo alguns autores $18,25,26,49,87,104,112,131,141,144,171,180,191,195$, é muito grande a influência da termociclagem nos resultados de avaliação da microinfiltração. Entretanto, alguns autores $35,39,48,50,55,61,78,79,88,105,127,155,170,202$ não encontraram diferenças significantes na microinfiltração quando compararam espécimes termociclados e não termociclados. Percebe-se com isto, que na literatura existe uma grande diversidade nos resultados obtidos pelos autores com relação a efetividade da ciclagem térmica no estudo da microinfiltração marginal $\left.\right|^{39,47,48,49,50,57,104,195}$, e várias são as hipóteses sugeridas para estas diferenças: as diferentes temperaturas utilizadas na ciclagem térmica, duração de cada banho, número de ciclos e, em qual substância os corpos de prova foram ciclados. Em algumas pesquisas as ciclagens térmicas foram realizadas em água

destilada $2,8,25,35,37,39,48,50,52,56,57,61,72,73,78,88,89,97,112,116,125,127,136,152,165,166,168,171,175,182,184,185,189$, 190,201,202 , outras em corantes $26,49,53,55,68,116,117,150,156,168,170,180,202$ e até mesmo em saliva artificial $^{5}$. Toda esta variedade de metodologias e resultados contraditórios com relação a ciclagem térmica demonstra a inexistência de um consenso a respeito deste assunto e a grande necessidade de padronização dos testes de microinfiltração ${ }^{157,178,191}$. 
Associado à ciclagem térmica vários métodos para se detectar e avaliar a microinfiltração ao redor das restaurações, têm sido discutidos por diferentes autores ${ }^{1,10,82,104,111,171,173,191,196,199}$, como infiltração de corantes orgânicos, agentes traçadores químicos, traçadores radioativos, bactérias, pressão positiva pelo uso de ar comprimido, produção de cáries artificiais, análises em microscópio eletrônico de varredura, análise por meio de ativação de neutrons e condução eletroquímica.

Uma parte da presente pesquisa, baseada em estudos prévios, avaliou a influência da termociclagem na microinfiltração de restaurações de resina composta, uma vez que, como já citado, os efeitos da ciclagem térmica na integridade marginal de restaurações de resina composta não é ainda muito clara na literatura, o que não permite comparações seguras entre os variados trabalhos existentes com metodologias diferentes. Procurou-se utilizar neste estudo as temperaturas mais citadas em outros trabalhos $8,16,17,26,35,37,52,53,56,57,61,89,93,112,125,165,166,170,175,182,190,200,204$, e que foram descritas como as mais aceitáveis por pacientes "in vivo", as de $5^{\circ}$ e $55^{\circ} \mathrm{C}$. O tempo de permanência nos banhos térmicos também foi o descrito na literatura como o suportável pelo ser humano, 15 segundos $^{35,116,160,168,182,200,202}$. A variável, então, foi o número de ciclos térmicos a que foram submetidas as restaurações $0,100,200$ e 1000 ciclos, na tentativa de se detectar diferenças na microinfiltração entre os grupos testados.

Como descrito acima, várias são as maneiras de se avaliar a microinfiltração em conjunto com a termociclagem mas, um dos meios mais usados e também um dos mais antigos é a utilização de corantes orgânicos ${ }^{1,26,35,38,39,48,49,50,53,55,56,59,68,72,73,89,117,150,156,166,167,170,175,180,181,184,189,202 . ~}$

Talvez por ser o de mais fácil aquisição, menos oneroso e segundo alguns autores com a vantagem de favorecer a avaliação em toda a periferia da restauração $0^{1,10,68,82,154,191}$, produzindo cores contrastantes com a superfície do dente e da restauração, sem necessitar de uma reação química ou radiação como no caso, por exemplo, dos traçadores químicos. Seguindo a metodologia de outros trabalhos e seguindo a afirmação de CRIM; SWARTZ; PHILLIPS ${ }^{50}$, que concluíram que o uso de corantes ou outras substâncias como isótopos, por exemplo, poderia ser estabelecido de acordo com a preferência do 
pesquisador, uma vez que ambos os métodos requerem uma técnica meticulosa e padronização de critérios de avaliação do grau de penetração dos mesmos e produzindo resultados equivalentes quando comparados, neste utilizou-se a fucsina básica $26,35,48,49,50,56,72,73,89,117,167,170,175,181,184,189,191,202$ como traçador da microinfiltração.

Para a realização de pesquisas "in vitro" os dentes mais comumente utilizados são os humanos extraídos, principalmente incisivos $^{93,97,156,185} \quad$,caninos $^{74,116,117,166,167}$, prémolares $^{17,38,39,48,49,50,52,56,78,81,87,95,97,105,108,132,165,167,181,182,190,201,204}$, molares $26,37,47,53,57,68,85,89,116,120,125,145,151,155,160,167,170,175,190,191,195,201,202,205$. Devido a facilidade em se obter pré-molares extraídos por razões ortodônticas, optouse então por realizar as restaurações nestes dentes.

Os tipos de preparos cavitários utilizados para estas pesquisas também variam muito na literatura. Alguns autores utilizam cavidades de Classe II estritamente proximal $\left.\right|^{6,32,53,73,125}$, e outros Classe II MOD $17,57,61,65,68,115,132,151,155,168,182,202$. A cavidade selecionada para este estudo foi a de Classe V, utilizada também por vários

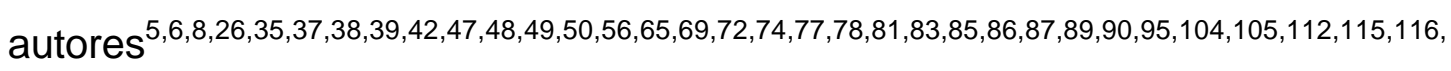
$117,136,137,138,144,145,150,151,152,153,155,156,160,165,166,170,171,167,177,185,189,191,195,201$. escolha recaiu para este tipo de preparo cavitário principalmente por ser este de fácil execução, portanto de fácil padronização, assim como a facilidade de padronização da técnica de inserção e polimerização da resina composta no interior da cavidade.

A localização das margens das restaurações também variam muito para este tipo de teste. Alguns autores utilizam cavidades com margem totalmente em esmalte $26,37,48,49,50,87,144,145,150,165,181$, outros com uma parte em $\begin{array}{lllll}\text { esmalte } & \mathrm{e} & \text { outra } & \mathrm{em} & \text { cemento }\end{array}$ dentina $35,53,56,65,68,72,73,85,89,116,127,136,166,167,170,175,182,185,190,201,202$, outros ainda com todas as margens em cemento e/ou dentina $17,38,39,43,52,77,95,112,125,132,155,204$. Seguindo a determinação da ADA, que estipulou que para testes com materiais adesivos dentinários, o preparo cavitário deveria ser localizado exclusivamente em dentina e/ou cemento ${ }^{161}$ e baseados em várias pesquisas ${ }^{17,120,151}$ que observaram que as margens localizadas em cemento e/ou dentina são mais 
propensas à infiltração marginal por serem estes tecidos mais complexos com relação ao seu preparo para adesão ao material restaurador, optou-se por realizar neste estudo preparos circulares de Classe $\mathrm{V}$ com todas as margens localizadas em cemento e/ou dentina.

O material restaurador escolhido para esta pesquisa foi a resina composta Z 100 ( 3M ) por ser uma resina bastante utilizada para restaurações de dentes anteriores e posteriores e o sistema adesivo empregado foi 0 Scotchbond Multi Purpose Plus ( $3 \mathrm{M}$ ). O fabricante deste sistema adesivo cita em seu encarte de instruções de uso que o ácido fosfórico à $37 \%$ e o ácido maleico à $10 \%$ quando usados em dentina por 15 segundos proporcionam 0 mesmo condicionamento (Figura 6.1).

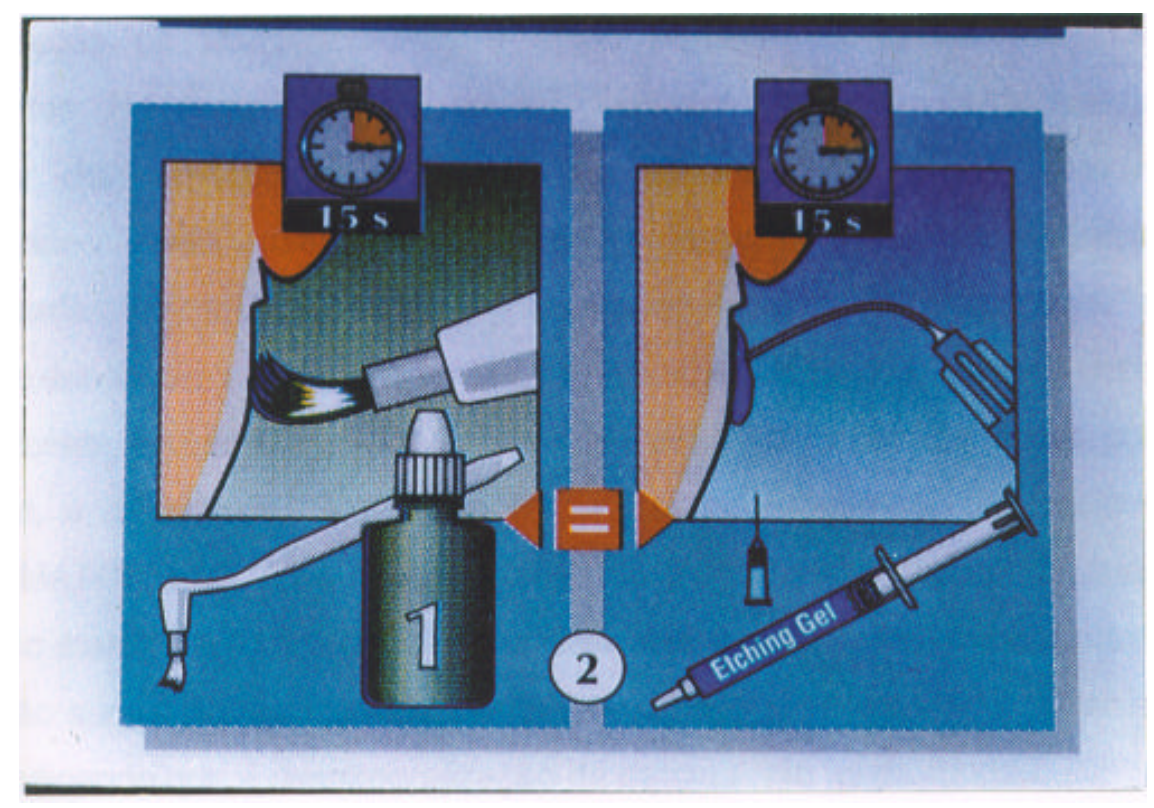

FIGURA 6.1: Encarte fornecido pelo fabricante juntamente com o Kit do Scotchbond Multi Purpose Plus (3M)

$\mathrm{Na}$ literatura, entretanto, existe uma controvérsia sobre o assunto. VAN MEERBEEK et $\mathrm{al}^{197}$, examinou ultramorfologicamente por meio de um microscópio de transmissão a interface resina/dentina formada por dois adesivos, o Optibond (Kerr), que utiliza como condicionador de dentina o ácido fosfórico e o Scotchbond Multipurpose (3M), que utiliza o ácido maleico a 10\% para condicionar dentina. Observaram que os dois sistemas adesivos foram 
capazes de estabelecer uma união micromecânica entre dentina e resina com a formação de uma camada híbrida. Entretanto o Optibond apresentou uma camada híbrida relativamente uniforme e ácido resistente. Estes parâmetros foram encontrados com mais variáveis na camada híbrida formada pelo Scothbond, além de uma fase amorfa depositada na superfície externa desta camada, o que permitiu aos autores detectar que as diferentes formulações químicas destes adesivos resultam em diferentes mecanismos de interligações adesivas. Porém relataram que a significância clínica destes achados morfológicos ainda não eram conhecidos.

Os estudos de GOES et al. ${ }^{80}$ e MATOS et al. ${ }^{118}$, que avaliaram a morfologia do esmalte e da dentina condicionados com diferentes concentrações de ácido fosfórico e ácido maleico, obtiveram resultados semelhantes. No esmalte, GOES et al. $^{80}$, concluíram que o ácido maleico necessita de um tempo maior de condicionamento para promover retentividades nesta estrutura. O mesmo autor analisando a dentina condicionada por este ácido, notou a presença de resíduos de "smear layer" na superfície depois de 15 ou 60 segundos de aplicação, e sugeriu que isto ocorre provavelmente porque este ácido é um ácido orgânico e possui um alto peso molecular, o que requer um tempo maior para a reação na superfície da dentina. MATOS et $\mathrm{al}^{118}$, ao observar fotomicrografias da dentina condicionada com ácido maleico à 10\%, por 15 segundos, observaram que ocorreu somente a remoção superficial da camada de "smear layer", permanecendo os "smear plugs", indicando que a desmineralização da dentina não foi profunda.

Em um estudo comparando a permeabilidade dentinária com diferentes concentrações e tempo de aplicação do ácido maleico, CAMPS et al. $^{33}$, relataram que a recomendação do fabricante de se utilizar o condicionador do Scotchbond Multi- Purpose (ácido maleico à 10\%) por 15 segundos, produz um condicionamento moderado da dentina, e aumenta a permeabilidade dentinária em apenas $1 / 4$ do valor obtido com 0 mesmo ácido por 60 segundos.

Avaliando a microinfiltração de restaurações de resina composta, utilizando o ácido maleico à 10\% como condicionador de dentina e de esmalte, em diferentes tempos de aplicação (15, 30 e 60 segundos), OWENS ${ }^{145}$, 
averiguou que quando ambas estruturas eram atacadas por somente 15 seg., como indica o fabricante, os dentes restaurados mostraram uma enorme infiltração. O autor sugeriu então, que ao usar este ácido, seja ampliada para 30 seg. sua aplicação, para se obter menor grau de infiltração marginal. Da mesma forma, OPDAM; ROETERS; BURGERSDIJK ${ }^{142}$, encontraram maior grau de infiltração marginal com a utilização do ácido maleico em comparação com o ácido fosfórico.

Por outro lado, BECK; SWIFT; DENEHY ${ }^{11}$, verificando a utilização do ácido fosfórico à 35\% e o ácido maleico à 10\% com relação a resistência ao cisalhamento do Scothbond Multi-Uso, em dentina, obtiveram resultados semelhantes para os dois condicionadores. A análise da superfície da dentina por microscopia eletrônica de varredura, demonstrou que os dois ácidos removem completamente a "smear layer" e descalcificam a dentina subjacente. O mesmo resultado foi encontrado por CAGIDIACO; FERRARI; DAVIDSON ${ }^{32}$, que compararam "in vivo" e "in vitro" a desmineralização dentinária obtida pelo condicionamento com ácido fosfórico à $36 \%$ e ácido maleico à $10 \%$. Ao comparar as amostras em um microscópio eletrônico de varredura, concluíram que os ácidos são similarmente efetivos na completa remoção da "smear layer" e na desmineralização da dentina, proporcionando porosidades na rede de fibras colágenas. Acrescentaram ainda, que o condicionamento "in vitro" e "in vivo" produzem dentina micromorfologicamente similares.

Frente a estes vários resultados obtidos na literatura, optou-se pela utilização do ácido maleico por ser este um ácido mais fraco e portanto menos agressivo ao órgão pulpar, aplicado por 15 segundos sobre a dentina, conforme recomendação do fabricante. Entretanto, quando foi realizada a segunda etapa da pesquisa, onde mudou-se o corante, que passou a ser o azul de metileno à $2 \%$ e as outras variáveis permaneceram as mesmas, notou-se a impossibilidade de leitura por ocorrer sempre uma grande infiltração do corante na interface dente/restauração. Algumas possíveis justificativas para a ocorrência deste fenômeno de infiltração total podem recair sobre o peso molecular do azul de metileno que é bem mais baixo que o da fucsina, o que permite que este penetre mais fácil e profundamente na interface dente/restauração. Aliado ao fato deste corante ser ácido ( $\mathrm{pH} 3.2$ ), o que 
provoca uma pequena desmineralização da superfície dentinária, permitindo uma maior penetração do corante na interface, já que todas as margens da cavidade se encontram em cemento e/ ou dentina. Uma opção seria a utilização do mesmo corante tamponado (não ácido), entretanto parece haver uma reação entre o adesivo e o corante, provavelmente com o ácido polialcenóico presente no adesivo, mascarando a infiltração real e impossibilitando a utilização deste corante com o adesivo usado nesta pesquisa. Além das hipótese levantadas acima existe ainda o fato de o ácido maleico, por ser um ácido fraco, não remover totalmente a "smear layer", deixando sempre o "smear plug" ${ }^{118}$ e, portanto ao se utilizar o sistema adesivo dentinário a camada híbrida formada torna-se bem mais fraca que a formada quando da utilização do ácido fosfórico à $37 \%{ }^{197}$, aumentando assim a microinfiltração. Alguns autores dizem que para que o condicionamento da dentina com ácido maleico à $10 \%$ tenha a morfologia semelhante do conseguido com o ácido fosfórico à $37 \%$, o tempo de aplicação do primeiro tem que ser aumentado ${ }^{33,80}$. Portanto, pode ter ocorrido uma interação de todos os itens acima citados, impedindo que se realizasse uma comparação dos dois corantes em relação a microinfiltração marginal conforme a forma desenvolvida neste trabalho.

Depois de submetidos às condições experimentais préestabelecidas pelo estudo, os dentes foram embebidos em cilindros de resina epóxica transparente, de tal forma que se pudesse identificar as faces vestibular e lingual. Depois disto, os espécimes foram seccionados em aproximadamente quatro cortes de $0,5 \mathrm{~mm}$ cada um, para que se pudesse observar a infiltração marginal do corante ao longo de toda a interface dente/restauração, assim como DÉJOU; SINDRE; CAMPS ${ }^{56}$ sugeriram, e não como em alguns trabalhos onde as restaurações são seccionadas longitudinalmente ao meio, promovendo apenas dois cortes para exame, e nem sempre a região de maior infiltração ao longo da interface se localiza no centro da restauração. O que pode mascarar ou alterar o resultado do teste.

Para avaliar os espécimes, existem os testes qualitativos e quantitativos. Como na literatura não existe uma concordância sobre qual seria o melhor método, ou se existiria alguma diferença entre eles, embora alguns 
autores citem os métodos quantitativos como mais precisos ${ }^{161,172}$, neste trabalho comparou-se também as duas formas de análises. Sendo a qualitativa realizada por meio de microscópio, e o índice de penetração do corante estabelecido por atribuição de escores, por dois examinadores. O método qualitativo, puramente visual, para a avaliação dos resultados e conseqüente adoção de uma escala empírica de cálculo de infiltração marginal, parece ser satisfatório somente para demonstrar o fenômeno da infiltração marginal. Quando se deseja estudar variáveis mais sutis, como a influência da rugosidade das paredes cavitárias na infiltração marginal, métodos de avaliação mais precisos são desejáveis ${ }^{126,173}$. A escala adotada por este trabalho foi graduada de 0 a 4, de acordo com a penetração do corante na interface dente/restauração, baseada em vários trabalhos encontrados na literatura $8,35,38,39,53,89,87,116,126,142,145,202$, pois pareceu ser a mais apropriada para as cavidades testadas. Ao se aumentar a graduação da escala, aumenta também o grau de dificuldade para a avaliação, pois o limite entre um grau e outro fica muito próximo, confundindo na maioria das vezes os examinadores.

Já a análise quantitativa foi realizada por dois métodos, medida linear da infiltração do corante na interface e a medida da área total da infiltração do mesmo; estas duas, por meio do programa de computador Image Tools da Universidade de San-Antonio - Texas (UTHSCSH). Os métodos que utilizam imagens digitalizadas para medir a quantidade de penetração do corante, em $\mathrm{mm}$ e em $\mathrm{mm}^{2}$, ao longo da interface dente/restauração, permitem uma forma mais objetiva de observar a extensão da infiltração marginal em comparação aos métodos tradicionais que utilizam meios qualitativos e não quantitativos para este fim ${ }^{68,165,204}$. Uma outra variável do trabalho, foi o valor utilizado para a análise da infiltração, utilizou-se o maior valor de infiltração de cada espécime (escore, linear e área), que segundo DËJOU; SINDRE; CAMPS $^{56}$, pareceu serem os melhores critérios para a avaliação de microinfiltração, e também a média de todas as leituras de cada espécime. Estes três métodos, após serem aplicados e avaliados estatisticamente foram comparados entre si (Tabela VI), observando-se uma grande correlação para todas as comparações, o que possibilita concluir que os métodos de avaliação se equivalem. 


\subsection{Da Termociclagem}

Os resultados deste estudo não demonstraram diferenças significantes entre as diversas variáveis testadas com relação a termociclagem.

Foi observado que não há concretas evidências de que a microinfiltração ocorreu por causa dos estresses térmicos utilizados, ou seja, 100, 200 e 1000 ciclos. Uma explicação poderia ser dada pelos achados de $E A K L E^{61}$, que conclui ser a contração de polimerização, responsável por produzir significante microinfiltração em restaurações de resina composta, independente da ciclagem térmica. $O$ mesmo autor ${ }^{61}$, também sugeriu que, em contraste com a rápida contração de polimerização da resina, o alívio do estresse causado por ela, por meio da expansão higroscópica, aconteceria mais lentamente. Em resumo, restaurações de resina composta, contraem durante a polimerização, resultando em indução de estresse na interface dente/restauração, a qual pode romper a interface adesiva. Subseqüentemente, ocorre a sorpção de água pela resina, melhorando a adaptação marginal das restaurações, mas não restabelecendo a união adesiva rompida pela contração de polimerização $0^{4,18,90,163}$.

Alguns autores ${ }^{49,186}$ acreditam que as mudanças térmicas podem danificar a adaptação das resinas compostas às paredes cavitárias, podendo ter algum efeito sobre a largura do microespaço formado.

A utilização de ciclos repetidos de estresse térmico no estudo de microinfiltração se deve, em grande parte, ao trabalho de NELSEN et al. ${ }^{141}$, que mostrou que dentes restaurados quando armazenados em água gelada, eliminam pequenas gotas de água das margens da restauração. Esta troca de fluídos se deve a diferença no coeficiente de expansão térmica linear entre a estrutura dentária e o material restaurador. Teoricamente, uma grande diferença entre o coeficiente de expansão térmica do material restaurador e o dente, causa uma enorme infiltração marginal, que ocorre durante as mudanças térmicas. Por exemplo, o alto coeficiente de expansão térmica das resinas (aproximadamente $80 \mathrm{ppm} /{ }^{\circ} \mathrm{C}$ ), comparado com o da estrutura dentária $\left(11 \mathrm{ppm} /{ }^{\circ} \mathrm{C}\right)$, é considerado uma séria deficiência destes materiais. $\mathrm{O}$ efeito da 
ciclagem térmica, causa alternadamente o aumento e a diminuição do espaço existente entre o material e a estrutura dentária ${ }^{82}$.

GUSMAN et al. ${ }^{88}$, relataram que o fenômeno da microinfiltração ou "percolação marginal" deu origem a teoria de que o coeficiente de expansão térmica linear dos materiais deveriam igualar-se tanto quanto possível, ao da estrutura dentária. Desta forma, até hoje, somente o cimento de silicato, 0 cimento de ionomêro de vidro e o ouro em folha vêm cumprindo este equilíbrio.

Em uma revisão da literatura, KIDD et al. ${ }^{104}$, notaram que resultados de experimentos utilizando ciclagem térmica tinham quase que invariavelmente um aumento na infiltração, e concluíram ser óbvia a necessidade do estresse térmico para trabalhos sobre infiltração marginal. Entretanto, um pouco mais tarde, KIDD et al. ${ }^{105}$, em um outro trabalho, sugeriram que a percolação térmica poderia não ter significância clínica em relação às resinas compostas.

Assim também GLYN-JONES; GRIEVE; KIDD ${ }^{79}$, afirmaram ser preciso ter em mente que o método de testar microinfiltração "in vitro", avalia a capacidade inicial do selamento cavitário, mas não necessariamente prediz o padrão de microinfiltração a longo tempo. Os resultados encontrados pelos autores com relação a ciclagem térmica dentro da realidade clínica de temperatura, não afetaram a microinfiltração em restaurações de resina. Com isto, conduziram a questionamentos sobre a questão da significância clínica do estresse térmico em relação a este material e, mais recentemente sugeriram outros fatores, como o módulo de elasticidade e difusibilidade térmica, por exemplo, como mais importante para o selamento cavitário de restaurações de resina, do que o coeficiente de expansão térmica, fato este que concordam KIDD; HARRINGTON; GRIEVE ${ }^{105}$. HAR.PER et al. ${ }^{93}$, também concordam com esta hipótese, indicando que há uma pequena mudança de temperatura embaixo da resina durante a ingestão de alimentos e bebidas, por causa da lenta difusão do calor através deste material. Isto sugere que mudanças dimensionais devido a expansão térmica podem não ser tão grandes quanto o coeficiente de expansão térmica parece produzir. O fato de ser improvável um paciente tolerar o contato direto de um dente vital com substâncias 
extremamente quentes ou frias, por um longo período de tempo, parece ser um fator de segurança intrínseca das restaurações em situações clínicas ${ }^{36,100,178}$.

BARNES et al. $^{8}$, sugeriram em virtude da grande controvérsia sobre a necessidade ou não da termociclagem, mais pesquisas com relação a diferentes números de ciclos durante a ciclagem térmica.

Outro fato interessante relatado por ROSSOMANDO; WENDT ${ }^{170}$, foi o de que os dentes restaurados com resina, quando termociclados imediatamente após ao término da restauração, apresentaram uma mais alta penetração do corante comparados com os espécimes que permaneceram estocados em água antes da ciclagem térmica. Isto foi atribuído ao potencial de sorpção das resinas e, foi então recomendado que os testes de microinfiltração deveriam ser realizados somente 24 horas depois dos espécimes permanecerem estocados, para permitir primeiramente a sorpção de água pela resina ${ }^{49}$. Este período, respeitado neste experimento, pode ser um dos fatores que colaboraram para que não houvessem diferenças significantes entre os números de ciclos testados, pois todos os grupos permaneceram estocados pelo mesmo período (24 horas), e por conseqüência, sofreram a mesma sorpção.

Deve-se levar em consideração também, o experimento realizado por HEMBREE ${ }^{96}$, que avaliou a microinfiltração em cavidades com diâmetros pequenos $(1,5 \mathrm{~mm})$ e com diâmetros maiores $(3 \mathrm{~mm})$, e encontrou infiltração marginal bem menor nas cavidades de pequeno diâmetro, e atribuiu isto a expansão do material, ou seja, em cavidades maiores a expansão é considerada pequena para compensar a grande contração de polimerização devido ao volume maior de material restaurador.

Os resultados obtidos neste trabalho, são coincidentes também com os de WENDT; Mc INNES; DICKINSON ${ }^{202}$ e de SMITH et al. ${ }^{181}$, que empregaram de 250 a 500 ciclos e períodos de imersão de 15 segundos em cada banho, e não notaram mudanças significantes nos padrões de infiltração marginal dos espécimes termociclados quando comparados com os não termociclados. O mesmo foi afirmado por outras pesquisas ${ }^{30,55,61,76,78,116,202}$.

CRIM; SWARTZ; PHILLIPS ${ }^{50}$, não encontraram diferenças significantes entre quatro técnicas de termociclagem. Entretanto, a semelhança 
dos resultados obtidos no presente trabalho, os espécimes que não foram submetidos a termociclagem exibiram numericamente uma microinfiltração bem menor do que os espécimes que receberam termociclagem.

É importante observar também, que nos resultados aqui obtidos, o padrão de infiltração entre os grupos que sofreram termociclagem, não obedeceram a seqüência esperada, ou seja, a quantidade de microinfiltração não aumentou proporcionalmente ao número de ciclos empregados, e pode ser claramente observado nas Figuras I, II, III, IV, V e VI, independente do método de avaliação utilizado. Por exemplo, na Figura I, que representa a média dos valores médios de penetração do corante, obtidos por meio da leitura por escores, pode-se observar que os espécimes de Grupo 3, submetidos a 200 ciclos, demonstraram uma infiltração maior $(0,596)$ que a do Grupo $4(0,542)$, submetido a 1000 ciclos. Fato semelhante ocorreu nas leituras pela média dos valores médios de penetração do corante por meio da leitura da medida linear (100 ciclos: 0,430mm; 200 ciclos: 0,281mm; 1000 ciclos: 0,302mm) (Figura II) e da área $\left(100\right.$ ciclos: $0,175 \mathrm{~mm}^{2} ; 200$ ciclos: $0,085 \mathrm{~mm}^{2} ; 1000$ ciclos: $0,063 \mathrm{~mm}^{2}$ ) (Figura III), assim como na média dos valores máximos por meio da leitura linear (Figura V) e da área (Figura VI), onde os espécimes do Grupo 2 (100 ciclos) apresentaram valores de infiltração maiores (linear:1,247mm e área: $0,769 \mathrm{~mm}^{2}$ ) que os Grupos 3 (200 ciclos) ( linear: 0,684mm e área: $0,348 \mathrm{~mm}^{2}$ ) e 4 (1000 ciclos) (linear: $0,971 \mathrm{~mm}$ e área: $0,232 \mathrm{~mm}^{2}$ ). E ao se comparar as médias dos valores máximos de penetração do corante por meio da leitura por escores (Figura IV), os Grupos 2 (100 ciclos: 1,368), 3 (200 ciclos: 1,263$)$ e 4 (1000 ciclos: 1,421$)$, obtiveram um grau de infiltração muito semelhante.

Entretanto, em todas as situações, o menor grau de infiltração marginal foi observado no grupo não ciclado (Figura I: 0,218; Figura II: 0,068mm; Figura III: 0,009 $\mathrm{mm}^{2}$; Figura IV: 0,508; Figura V: 0,266mm; Figura VI: $0,039 \mathrm{~mm}^{2}$ ). Embora esses valores tenham sido numericamente bem menores quando comparados aos dos grupos ciclados, como podemos observar pelos valores médios de infiltração de cada grupo, as diferenças entre eles não foram estatisticamente significantes. Isto pode ser explicado pela grande variabilidade dos valores de infiltração em um mesmo grupo (Tabelas I, II, III e IV). Ou seja, 
em um mesmo grupo, encontramos resultados extremos muito diferentes, o que proporciona uma curva de distribuição de valores que foge da normal, e com isto, a média obtida assume valores muito altos.

Quando a curva de resultados obtida por um teste não se apresenta de forma normal, o teste estatístico mais indicado para a comparação entre grupos é o não paramétrico ${ }^{172}$. Aqui, o teste utilizado foi o de Kruskall Wallis, e estes testes não se baseiam na média dos resultados, justamente para não incorrer em erros, influenciados pela grande variabilidade dos valores que faz com que estas médias sejam muito altas ou baixas, dependendo dos valores. Os testes não se baseiam na mediana dos valores, que nesta pesquisa, não se apresentaram altas e diferentes, conforme pode ser visto nas Tabelas I, II, III e IV.

Com os resultados deste trabalho podemos afirmar que, ocorreram diferenças numéricas entre os corpos ciclados e não ciclados observando as médias dos valores obtidos (Figuras I, II, III, IV, V e VI). Entretanto, conforme a Tabela $V$, que compara os grupos levando em consideração o número de ciclos, se fosse afirmado haver diferenças estatísticas entre o grupo não ciclado e os ciclados, teríamos uma chance de erro de $39 \%$ a $46 \%$, ao nível de $5 \%$ de significância. Portanto, diferenças numéricas existiram neste trabalho, mas o resultado com relação a ciclagem térmica, não pode ser conclusivo e estrapolado para outros testes, pois, estatisticamente não se mostraram significantes, nas condições em que foi desenvolvido.

Uma outra justificativa para este comportamento, talvez seja a de que estes números de ciclos não levam o material a ultrapassar o seu grau de fadiga, o que significa que este material, com estas termociclagens, não perdeu a capacidade de se expandir e contrair frente a estas mudanças térmicas. Quando um material entra em fadiga, não se altera volumetricamente frente a mudanças de temperatura ${ }^{*}, 25$. Devemos levar em consideração também o ácido utilizado (maleico a 10\%), que em alguns trabalhos ${ }^{80,118,197}$, mostrou-se incapaz de remover totalmente a "smear layer", deixando alguns detritos sobre a dentina, o que dificulta a formação de uma camada híbrida resistente, capaz de 
se romper facilmente, até mesmo pela contração de polimerização da própria resina e de igualar os valores de infiltração de todos os grupos, independentemente da influência da ciclagem térmica.

Alguns autores tem relatado que o efeito da termociclagem na microinfiltração pode ser severamente aumentado com a aplicação de carregamentos oclusais cíclicos. JÖRGENSEN ${ }^{101}$ foi o autor que introduziu o termo "percolação mecânica", para demonstrar fatores mecânicos no ambiente oral que pudessem produzir microespaços entre o material e a estrutura dentária.

Tem-se demonstrado que a ciclagem mecânica de dentes restaurados pode aumentar a quantidade de deformação permanente ${ }^{102,117}$. A instabilidade dimensional de restaurações em dentes que sofrem carregamentos cíclicos, indicam um severo risco de percolação para vários materiais restauradores, assim como levam a fraturas marginais ${ }^{178}$.

Entretanto, outros trabalhos encontraram que cargas cíclicas não têm efeito adicional na dimensão do microespaço marginal ${ }^{135}$. Com esta variedade de afirmações, MANDRAS; RETIEF; RUSSELL ${ }^{116}$, sugeriram que em avaliações laboratoriais de microinfiltração, os dentes deveriam ser submetidos a ambos estresses, térmico e carregamento oclusal, simulando mais rigorosamente as condições intra-orais. $O$ estresse mastigatório pode diminuir o tempo de vida de uma restauração adesiva "in vivo", como as cargas cíclicas podem induzir a falhas de adesão "in vitro"1,136.

Por outro lado, outros autores ${ }^{52,107,136}$ não encontraram diferenças significantes na microinfiltração entre espécimes termociclados, termociclados e com carregamento oclusal e somente com carregamento oclusal. PRATI et al. ${ }^{155}$, também não encontraram aumento na microinfiltração em restaurações que sofreram estresse térmico e oclusal.

Avaliando a microinfiltração como um processo inevitável de restaurações de resina composta, como confirmado na presente pesquisa, uma das maneiras de se minimizar este desagradável acontecimento, encontrados na literatura, é a utilização de uma base de cimento de ionômero de vidro sob a restauração de resina composta, já que é um procedimento restaurador que associa as características desejáveis do cimento de ionômero de vidro e da 
resina composta, compensando as deficiências de ambos $53,115,121,139,140,182,206$. Assim como a aplicação de um selante de superfície sobre a restauração de resina composta, técnica esta sugerida por alguns autores ${ }^{29,109,156}$. Sugestão comprovada no trabalho de MENDONÇA ${ }^{122}$, onde a aplicação de um selante sobre as restaurações de resina composta, eliminaram totalmente a microinfiltração. Em outros estudos, mais recentes, MIRANDA ${ }^{126}$ e VERONEZI et $\mathrm{al}^{198}$, utilizando selantes de superfície sobre restaurações de resina composta, após o polimento, também encontraram redução significante na infiltração marginal, porém não a eliminação completa desta.

\subsection{Dos Métodos de Avaliação}

Uma grande variedade de métodos tem sido descritos para avaliar a eficiência do selamento de restaurações ${ }^{191}$. Testes utilizando a penetração de corantes têm sido usualmente utilizados por serem métodos mais simples e rápidos ${ }^{56}$. A avaliação é realizada por meio da medida da profundidade de penetração do corante em uma ou em várias secções dos dentes restaurados e embebidos em resina epóxica. A natureza do critério de avaliação (quantitativo, qualitativo ou ordinal) determina a força do teste estatístico realizado e consequentemente, a chance de chegar a uma conclusão positiva sobre o que se está testando ${ }^{56}$. Isto também determina a validade das condições destes testes (distribuição normal dos dados, uniformidade de variâncias), especialmente em casos de um pequeno número de amostras ${ }^{176}$.

Uma maneira de não se incorrer em grandes riscos de erro de leitura, é o utilizado neste trabalho, onde um mesmo espécime foi seccionado várias vezes, aproximadamente 4 , o que permitiu avaliar a infiltração do corante em toda a extensão da interface da restauração. Não ficando restrito somente a uma área de leitura, que na maioria das vezes não coincide com a localização onde ocorreu a maior penetração do corante, mascarando assim, o resultado do teste. 
A avaliação qualitativa, ou seja, o método puramente visual pode não ser tão preciso para medir o quanto do corante penetrou na interface dente/restauração, pois adota uma escala empírica para este cálculo e depende muito da acuidade visual dos examinadores.

Além disso, a dificuldade para definir um nível aceitável de penetração do corante, e a quantidade deste que penetrou na interface é muito importante ${ }^{172}$. Levando em consideração este fato, os testes quantitativos que realmente medem a quantidade de corante que penetrou na interface, parecem ser os de escolha para testes de infiltração e os que retratam com mais precisão este fenômeno segundo alguns autores ${ }^{59,95,168}$.

As séries estatísticas podem também ser avaliadas segundo a média, mediana ou moda dos valores obtidos, segundo o grau máximo de penetração do corante ou ainda pela porcentagem de espécimes que obtiveram grau zero de penetração de corante.

Nestas condições, o conceito do nível máximo de penetração do corante, parece liderar a eliminação do critério que utiliza valores médios (média, mediana e moda) $^{56}$. Entretanto, RASKIN et al ${ }^{158}$, em sua revisão encontrou a média como o critério mais utilizado, em $30,10 \%$ dos estudos por eles analisados seguido pelo critério de valores máximos de infiltração do corante, em $22,68 \%$ dos estudos.

A mediana não utiliza valores numéricos das observações, mas a posição central destes valores, não dependendo dos valores extremos ou aberrantes. A extrema microinfiltração permite a penetração de bactérias ou produtos bacterianos no assoalho cavitário, através do microespaço formado na interface dente/restauração e atingindo a câmara pulpar, fato este muito importante para não ser relevado durante a avaliação ${ }^{149}$.

A média é mais influenciada por estes extremos ou valores aberrantes, e pelos mais baixos resultados. Portanto, o "ranking" dos sistemas restauradores que utilizam o máximo de penetração do corante, parece cumprir com o papel definido por PASHLEY ${ }^{149}$, de que o mais importante nestes testes, é o valor máximo de infiltração em cada espécime. O método que utiliza a porcentagem de dentes em cada grupo sem nenhuma penetração do corante parece avaliar uma propriedade 
oposta a que se deseja, pois somente os dentes com perfeito selamento marginal são selecionados. Entretando, usando este critério, elimina-se qualquer dente com microinfiltração, permitindo assim, chegar ao mesmo fim. Contudo, os procedimentos estatísticos são bem mais complexos porque sempre requerem uma transformação angular dos dados ${ }^{56}$.

Com base nos resultados aqui obtidos, onde foram utilizados a média e o valor máximo, aplicados aos graus de penetração do corante, ou seja, leitura linear e área, como métodos quantitativos e leitura por escores, como método qualitativo, demonstraram uma grande tendência a se equivalerem, conforme demonstra a Tabela VI. Significando que todos os métodos de leitura testados, acompanham um mesmo padrão de valores, ou seja, quando se encontrou um escore alto de penetração do corante para um espécime, também se encontrou uma medida da área e linear proporcional de infiltração.

Resumindo, os dados obtidos aqui, permitem dizer que os trabalhos existentes na literatura que utilizam as diferentes metodologias de leitura de penetração de corante na interface dente/restauração, testadas por este estudo, ao contrário do obtido para a termociclagem, podem ter seus resultados comparados. 
7 - CONCLUSÕES 


\section{7- $\underline{\text { Conclusões }}$}

Com base na análise estatística dos valores obtidos, pode-se afirmar que:

- a termociclagem, nas condições em que foi empregada no presente trabalho, não demonstrou influencia significante na microinfiltração de restaurações de resina composta, quando comparados os grupos não termociclados e os termociclados (100, 200 e 1000);

- as metodologias de leitura qualitativa (escores) e quantitativas (linear e área), para medir a penetração do corante na interface dente/restauração se equivaleram, tanto nas avaliações dos valores médios como dos máximos de penetração do corante. 


\section{REFERENNCIAS BIBLIOGRAFICAS}




\section{$\underline{\text { Referências Bibliográficas }}^{*}$}

1- ALANI, A.H.; TOH,C.G. Detection of microleakage around dental restorations: a review. Oper. Dent., v.22, p.173-85, 1997.

2- ASMUSSEN, E. The effect of temperature changes on adaptation of resin fillings I. Acta. odont. Scand., v.32, n.3, p.161-71, Feb. 1974.

3- ASMUSSEN, E. Composite restorative resins. Composition versus wall-towall polymerization contraction. Acta odont. Scand., v.33, n.6, p.33744, June 1975.

4- ASMUSSEN, E.; JORGENSEN, K.D. A microscopic investigation of the adaptation of some plastic filling materials to dental cavity walls. Acta. Odont. Scand, v.30, p.3-21, 1972.

5- ÁVILA JÚNIOR, G. Estudo comparativo da infiltração marginal, com ciclagem térmica em restaurações feitas com materiais plásticos. Bauru, 1979, 74p. Dissertação (Mestrado) - Faculdade de Odontologia de Bauru, Universidade de São Paulo.

6- BARBER, D.; LYELL, J.; MASSLER, M. Effectiveness of copal resin varnish under amalgam restorations. J.prosth.Dent., v.4, p.533-6, 1964.

7- BARKMEIER, W.W.; ERICKSON, R.L. Shear bond strength of composite to enamel and dentin using Scotchbond Multi-Purpose. Amer.J.Dent., v.7, n.3, p.175-9, June 1994.

\footnotetext{
* Normas recomendadas para o uso no âmbito da Universidade de São Paulo, com base no documento "Referências Bibliográficas: exemplos", emanado do Conselho Superior do Sistema Integrado de Bibliotecas da USP, em reunião de 20 de setembro de 1990.
} 
8- BARNES, D.M. et al. Microleakage of class $V$ composite resin restorations: a comparison between in vivo and in vitro. Oper. Dent., v.18, p.237-45, 1993.

9- BARREIROS. I.D.; ARAÚJO, P. A., NAGEM FILHO, H. Eficiência do sistema adesivo em restaurações com resina composta, com determinados períodos de acabamento e polimento. Rev. Fac. Odont. Bauru, v.2, n.2, p.8-13, abr/jun.1994.

10- BAUER, J. G.; HENSON, J.L. Microleakage: a measure of the performance of direct filling materials. Oper. dent., v.9, n.1, p.2-9, 1984.

11- BECK, M.D.; SWIFT, E.J.; DENEHY, G.E. Use of phosphoric acid etchants with Scotchbond Multi-Purpose. J. dent.Res., v.72, p.133, 1993. Special Issue. /Abstract n.240/

12- BEN-AMAR, A. et al. The effect on marginal microleakage of using a combination of cavity varnished and calcium hydroxide intermediary bases - an in vitro study. Quintecensse Int., v.16, n.12, p.821-5, Dez. 1985.

13- BENDERLI, Y; YUCEL, T. The effect of surface treatment on the bond strength of resin composite to dentin. Oper.Dent., v. 24, n.2, p.96-102, Mar/Apr. 1999.

14- BERRY, E.A.; N. VON DER LEHR, W.; HERRIN, H.K. Dentin surface treatments for the removal of the smear layer: an SEM study. J.Amer.dent.Ass., v.115, p.65-7, 1987.

15- BLACK, G.V. Operative Dentistry, v.2. 7ed. Ed. Medio Dental Publishing Co, Chicago, p. 207, 1937 
16- BOEHM, R.F. Thermal environment of teeth during open mouth respiration. J.dent.Res., v.51, n.1, p.75-8, 1972.

17- BOTELHO, A. M. Avaliação da infiltração marginal em cavidades de classe II restauradas com resina composta associada a outros materiais restauradores. Bauru, 1999. 263p. Tese (Doutorado) Faculdade de Odontologia de Bauru, Universidade de São Paulo.

18- BOWEN, R.L.; RAPSON, J.E.; DICKSON, G. Hardening skrinkage and hygroscopic expansion of composite resins. J.dent.Res., v.61, n.5, p.654-82, May 1982.

19- BRADEN, M.; CAUSTON, E. E.; CLARKE, R.L. Diffusion of water in composite filling materials. J.dent.Res., v.55, n.5, p.730-2, Sept/Oct. 1976.

20- BRÄNNSTRÖM, M. The cause of post-restorative sensitivity and its prevention. J.Endod., v.12, p.475-81, 1986.

21- BRÄNNSTRÖM, Infection beneath composite resin restorations: can it be avoided?. Oper.Dent., v.12, p.158-63, 1987.

22- BRÄNNSTRÖM, M.; NYBORG, H. The presence of bacteria in cavities filled with silicate cement and composite resin materials. Svensk.Tand., v.64, p.149-55, 1971.

23- BRÄNNSTRÖM, M.; VOJINOVIC, O. Response of the dental pulp to invasion of bacteria around three filling materials. J.Dent.Child., v.43, p.83-9, 1976. 
24- BRÄNNSTRÖM, M.; GLANTZ, P.O.; NORDENVALL, K.J. The effect of some cleaning solutions on the morphology of dentin prepared in different ways: an in vivo study. J. dent. child., v.46, p.291-5, July/Aug. 1979.

25- BROWN, W.S.; JACOBS, H.R.; THOMPSON, R.E. Thermal fadigue in teeth. J.dent.Res., v.51, n.2, p.461-7, Mar/Apr. 1972.

26- BULLARD, R.H.; LEINFELDER, K.F.; RUSSEL, C. M. Effect of coefficient of thermal expansion on microleakage. J.Amer. dent. Ass., v.116, p.871-4, June 1988.

27- BUONOCORE, M.G. A simple method of increasing the adhesion of acrylic filling materials to enamel surfaces. J. dent. Res., v.34, n.6, p.849-53, Dec.1955.

28- BUONOCORE, M.G.; WILEMAN; W.; BRUDEVOLD, F. A report on a resin composition capable of bonding to human dentin surface. J.dent.Res., v.35, n.6, p.846-51, Aug.1956.

29- BUONOCORE, M. G. et al. Evaluation of enamel adhesive to prevent marginal leakage: an in vitro study. J. Dent. Child., v. 40, p.119-24, 1973.

30- BURGER, K.M.; COOLEY, R.L.; GARCIA-GODOY, F. Effect of thermocycling times on dentin bond strength. J.dent. Res., v.71, p.137, 1992. Special Issue. /Abstract n.256/.

31- BURKE, F.J.T. Dentine bonding agents-optimizing the use of composite materials. Dent. Update, v.18, p.96-104, Apr. 1991. 
32- CAGIDIACO, M.C.; FERRARI, M.; DAVIDSON, C.L. Comparison of in vivo and in vitro demineralized dentin with phosphoric and maleic acid. J. Dent._Child., v.64, n.1, p.17-21, Jan./Feb. 1997.

33- CAMPS, J. et al. Influence of concentration and application time of maleic acid on dentin permeability. Dent. Mat., v.11, n.3, p.177-81, May 1995.

34- CARVALHO, R.M. et al. A review of polimerization contraction: the influence of stress development versus stress relief. Oper.Dent., v.21, n.1, 17-24, Jan./Feb. 1996.

35- CASTAÑEDA, J.C. Avaliação da microinfiltração em restaurações mistas de classe $V$. Influência da contração de polimerização da resina composta, associado ao desenho cavitário, ao tratamento da superfície do cimento de ionômero de vidro e à ciclagem térmica. Bauru, 1991. 201p. Dissertação (Mestrado)- Faculdade de Odontologia de Bauru, Universidade de São Paulo.

36- CAUSTON, B. E. et al. Dental materials: 1981 literature review. Part 1. J.Dent., v.12, n.1, p.1-28, 1984.

37- CHALKLEY, Y.; JENSEN,M. Composite resin microleakage: effect of bonding agents and polishing times. J.dent.Res., v.63, p.179, 1984. Special Issue. /Abstract n.74/.

38- CHAN, M. F.WY.; GLYN-JONES, J.C. A comparison of four in vitro marginal leakage tests applied to root surface restorations. J. Dent., v.20, n.5, p.287-93, Apr.1992.

39- CHAN, M. F.WY.; GLYN-JONES, J.C. Significance of thermal cycling in microleakage analysis of root restorations. J.Dent., v.22, n.5, p.292-5, Jan.1994. 
40- CHAN, A. R. et al. A short-and long-term shear bond strength study using acids of varying dilutions on bovine dentine. J.Dent., v.25, n.2, p.14552, 1997.

41- CHRISTENSEN, G. J. Clinical factors affecting adhesion. Oper. Dent.. v.17, p.24-31, 1992. Suplement n.5.

42- CHRISTEN, A. G.; MITCHELL, D. F. A fluorescent dye method for demonstrating leakage around dental restorations. J.dent. Res.,v.45, n.2, p.1485-92, 1966.

43- CORREA, I.L.V. Influência na infiltração marginal de diferentes formas de tratamento da umidade em cavidades restauradas com Scotchbond Multi-Uso/Z-100. Bauru, 1996. 140p. Dissertação (Mestrado) - Faculdade de Odontologia de Bauru, Universidade de São Paulo.

44- COX, C. F. FELTON, D.; BERGENHOLTZ, G. Histopathological response of infected cavities treated with Gluma and Scotchbond dentin bonding agents. Amer. J. dent., v.1, p.189-4, 1988.

45- COX, C. F. et al. Biocompatility of surface-scaled dental materials against exposed pulps. J. prosth. Dent., v.57, p.1-8, 1987.

46- COY, H. D. Direct resin fillings. J.Amer. dent. Ass., v.47, n.5, p.532-7, Nov. 1953.

47- CRIM, G. A.; Effect of immediacte versus delayed thermal stress on two adhesives. Quintessence Int., v.20, n.7, p.517-9, July 1989.

48- CRIM, G. A.; GARCIA-GODOY, F. Microleakage: the effect of storage and cycling duration. J.prosth.Dent., v.53, n.5, p.574-6, May 1987. 
49- CRIM. G. A.; MATTINGLY, S. L. Evaluation of two methods for assessing marginal leakage. J.prosth.Dent., v.45, n.2, p.160-3, Feb.1981.

50- CRIM, G. A. SWARTZ, M. L.; PHILLIPS, R.W. Comparison of four thermocyclin techiques. J.prosth.Dent.,v.53, n.1, p.50-3, Jan.1985.

51- CRIM, G. A.; ESPOSTIO, G.J.; CHAPMAN, K.W. Microleakage whith a dentine-bonding agent. Gen. Dent., v.33, p.232-4, 1985.

52- DARBYSHIRE, P.A., MESSER, L.B.; DOUGLAS, W.H. Microleakage in class II composite resin restorations bonded to dentin using thermal and load cycling. J.dent. Res, v.67, n.3, p.585-7, Mar. 1988.

53- DAVIDSON, C. L.; ABDALLA, A. I. Effect of thermal and mechanical load cycling on the marginal integrity of class II resin composite restauration. Amer.J.Dent., v.6, n.1, p.39-42, Feb. 1993

54- DAVIS E. L. Adhesion of dentin bonding agents after smear layer treatments. Amer.J.Dent., v.5, n.1, p.29-32, Feb. 1992.

55- DERKSON, G.D.; PASHLEY, D.H.; DERKSON, M.E. Microleakage measurement of selected restorative materials: a new in vitro method. J.prosth. Dent., v.56, n.4, p.435-40, 1986.

56- DÉJOU, J.; SINDRES, V.; CAMPS, J. Influence of criteria on the results of in vitro evaluation of microleakage. Dent. Mater., v.12, p.342-9, Nov. 1996.

57- DIETSCHI, D. et al. Influence of the restorative tecnique and new adhesives on the dentin marginal seal and adaptation of resin composite Class II restauration: an in vitro evaluation Quintessence Int., v.26, n.10, p.717-27, Oct. 1995. 
58- DOLVEN, R.C. Micromeasurement of cavity lining, using ultraviolet and reflected light, and the effect of the liner on marginal penetration, evaluated with $\mathrm{Ca}^{45}$. J.dent.Res., v.45, n.1, p.12-5, 1966.

59- DOUGLAS, W. H.; ZAKARIASEN, V. Volumective assessment of apical leakage utilizing a spectrophotometric, dye-recovery method. J.dent.Res., v. 60, n.1, p.438. Jan/Mar. 1981. Special Issue. /Abstract n.512/.

60- DUKE, E. S. Adhesion and its application with restorative materials. Dent.Clin.N.Amer., v.37, n.3, p.329-40, 1993.

61- EAKLE, W. S. Effect of thermal cycling on fracture strength and microleakage in teeth restored with a bonded composite resin. Dent.Mat., v.2, n.3, p.114-7,1986.

62- EICK, J.D. et al. The dentinal surface: its influence on dentinal adhesion. Pat.III. Quintessence Int., v.24, n.8, p.571-82, Aug.1993.

63- ELIADES, G. Clinical relevance of the formulation and testing of dentine bonding systems. J.Dent., v.22, n.2, p.73-81, 1994.

64- ELLIS, J. M., BROWN, L. R. Aplication of an in vitro cariogenic technic to study the development of carious lesions around dental restorations. J.dent Res., v.46, n.2, p.403-8, 1967.

65- ERICKSON, J.; JENSEN, M. E. Effect of pressure cycling on microleakage at composite restorations margins. J.dent. Res., v.65, n.2, p.825, 1986. Special Issue. /Abstract.895/.

66- FARAH, J.W. et al. Resinas compostas Dent. Adv., v.22, n.2, p.1-8, Apr.1995. 
67- FARNEZI, G.G. Contribuição ao estudo da sorpção da água, contração de polimerização e expansão higroscópica em resinas restauradoras. Araraquara, 1980. 87p. Dissertação (Mestrado) Faculdade de Odontologia de Araraquara, Universidade do Estado de São Paulo.

68- FAYYAD, M. A.; SHORTALL, C.C. Microleakage of dentine-bonded posterior composite restorations . J.Dent., v.15, n.2, p.67-72, 1987.

69- FERRARI, M. The micromorphologic relationship between resin and dentin in class V restorations: an "in vivo" and "in vitro" investigation. Quintessence Int., v.25, n.3, p.621-5, Sept. 1994.

70- FIASCONARO, J.; SHERMAN, H. A quant itative method for evaluating the cavity sealing properties of restorations. J.dent. Res., v.31, n.4, p.503, 1952. Special Issue. /Abstract 114/.

71- FINGER, W.J.; MANABE, A.; ALKER, B. Dentin surface roughness vs. bond strength of dentin adhesives. Dent. Mater., v.5, n.5, p.319-23 Sept. 1989.

72- FUKS, A.B., HIRSCHFELD, Z; GRAJOWER, R. Marginal leakage of cervical resin restorations with a bonding agent. J.prosth. Dent, v.54, n.5, p.654-7, Nov. 1985.

73- FUTATSUKI, M.; NAKATA, M. In vitro marginal leakage of Class II composite resin restorations by thermal cycling. J. clin. pediat. Dent., v.8, n.3, p.191-6, 1994.

74- GALAN JUNIOR, J.; MONDELLI, J.; CORADAZZI, J.L.. Marginal leakage of two composite restorative systems. J.dent.Res., v.55, n.1, p.74-6, 1976. 
75- GALE, M. S.; CHEUNG, G.S.P. 3-D reconstruction of microleakage pattern using an abrasion technique. J.dent.Res., v.72, p.114,1993 /Abstract 88/

76- GALE, M. S.; DARVELL, B.W. Thermal cycling procedures for laboratory testing of dental restorations. J.Dent., v.27, n.2, p. 89-99, Feb. 1999.

77- GALE, M. S.; DARVELL, B.W.; CHEUNG, G.S.P. Three-dimensional reconstruction of microleakage pattern using a sequencial grinding technique. J.Dent., v.22, n.6, p.370-5, 1994.

78- GLYN JONES, J.C.; GRIEVE, A. R.; HARRINGTON, E. A machine for thermal cycling in the investigation of marginal leakage. Brit. dent. J., v.146, p.207-11, 1979.

79- GLYN-JONES, J.C.; GRIEVE, A.R.; KIDD, E.A M. Na in vitro comparison of marginal leakage associated with three resin based filling materials. Brit.dent. J., v.145, p.299-302, 1978.

80- GOES, M.F. et al. Morphological effect of the type, concentration and etching time of acid solutions on enamel and dentin surfaces. Braz.dent.J., v.9, n.1, p.3-10, 1998.

81- GOING , R. E. Marginal penetrations of dental restorations as studied by crystal violet dye and I ${ }^{131}$. J.Amer.dent Ass., v.61, p.285-300, 1960.

82- GOING, R. E. Microleakage around dental restorations: a summarizing review. J.Amer.dent.Ass., v.84, p.1349-57, June 1972.

83- GOING , R. E.; MASSLER, M. Influence of cavity liners under amalgam restorations on penetration by radioactive isotopes. J.prosth. Dent., v. 11, n. 2, p.298-312, 1961. 
84- GOING, R. E.; MYERS, H. M.; PRUSSIN, S.G. Quantitative method for studing microleakage in vivo and in vitro. J.dent.Res., v.47, n. 6, p.1128-32, 1968.

85- GORDON, M. et al. Microleakage of four composite resins over a glass ionomer cement base in class V restorations. Quintessence Int., v.16, p.817-20, Dec.1985.

86- GRIEVE, A. R. The occurrence of secondary caries-like lesions in vitro. Brit. dent.J., v.134, n.19, p.530-6, June 1973.

87- GRIEVE, A. R.; SAUNDERS, W.P.; ALANI, A. H. The effects of dentine bonding agents on marginal leakage of composite restorations-long term studies. J.oral Rehab., v.20, p.11-8, 1993.

88- GUSMAN, H.J.; SWARTZ, M.L.; PHILLIPS, R.W. Marginal leakage of dental restorations subjected to thermal stress. J. prosth. Dent., v.21, n.2, p.166-75, 1969.

89- HALLER, B. et al. Effect of storage media on microleakage of five dentin bonding agents. Dent. Mat, v.9, p.191-7, May 1993.

90- HANSEN, E. K. Visible light-cured composite resins: polymerization, contraction pattern and hygroscopic expansion. Scand.J.dent.Res., v.90, p.329-35, 1982.

91- HANSEN, E.K.; ASMUSSEN, E. Effect of posponed polishing on marginal adaptation of resin used with dentin-bonding agent. J.dent.Res., v.96, n.3, Mar.1988. 
92- HARPER, W.E. The character of the adaptation of amalgam to the walls of cavities attained by present methods of instrumentation and the use of the best know alloys, as indicated by the air pressure test. Dent.Rev., v.26, p.1179, 1912.

93- HARPER, R. H. et al. In vivo measurements of thermal diffusion through restorations of various materials. J.prosth. Dent., v.43, n.2, p.180-5, Feb.1980.

94- HARASHIMA, I; UZAWA, T.; HIRASAWA, T. A new method for the assessment of marginal sealebility of dental restorations. Dent.Mat., v.11, p.150-7, 1992

95- HASEGAWA, T.; RETIEF, D.H. Quantitative microleakage of some dentinal bonding restorative systems. Dent. Mat., v.9, p.114-7, Mar. 1993.

96- HEMBRE, J. H. Microleakage of composite resin inserted over an experimental linear: a laboratory study. J.prosth. Dent., v.46, p.94, 1981.

97- HEMBRE, J. H.; TAYLOR, T. In vitro marginal leakage of composite resin restorations using a combination of conventional and microfilled resins. Quintessence. Int., v.16, p.813-5, Dec.1985.

98- ITIRASAWA, T. et al. Initial dimensional change of composites in dry and wet conditions. J. dent. Res., v.62, p.28-30, 1983.

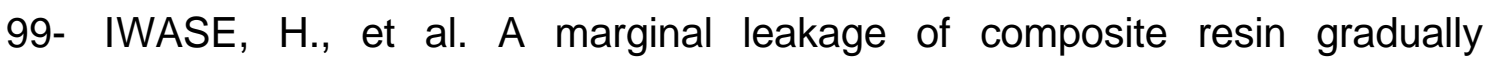
increased with thermal cycling. J.dent.Res., v.68, p.923, 1989. Special Issue. /Abstract 455/. 
100- JACOBSEN, P.H, The current status of composite restorative materials. Brit. dent.J., v.150, p.15-8, 1981.

101- JORGENSEN, K.D. Some observations on silicate cement. Acta. Odon. Scand., v.28, p. 117-27, 1970.

102- JORGENSEN, K.D.; MATONO, R.; SHIMOKOBE, H. Deformation of cavities and resin fillings in loaded teeth. Scand.J.dent.Res., v.84, p.46-50, 1976.

103- KANCA, J. A method for bonding to tooth structure. J.dent.Res., v.69, p.231,1990. Special Issue. /Abstract 984/.

104- KIDD, E. A. Microleakage: a review. J.Dent., v.4, n.5, p.199-206, Sept. 1976.

105- KIDD, E.A.M.; HARRINGTON. E.; GRIEVE, A. R. The cavity sealing ability of composite restorations subjected to thermal stress. J.oral Rehab., v.5, n.3, p.279-86, 1978.

106- KOIKE, T. et al. Effect of water sorption and thermal stress on cavity adaptation of dental composites. Dent.Mat, v.6, n.2, p.178-80, July 1990.

107- KREJCI, I.; KUSTER, M.; LUTZ, F. Influence of dentinal fluid and stress on marginal adaptation of resin composites. J. dent. Res., v. 72, p. 490-4, 1993.

108- LAMOSA, A.C. et al. Avaliação do efeito da termociclagem na adesão de adesivos dentinários de $5^{\mathrm{a}}$ geração. In: ENCONTRO BRASILEIRO DE PROFESSORES DE DENTÍSTICA, 13, Recife, 1999. Anais Recife, GB, 1999. 
109- LEE, H.L. An adhesive dental restorative material. J. dent. Res., v. 50, p.125-32, 1971.

110- LEE, H. L.; SWARTZ, M. L.; SMITH, F. F. Physical properties of four thermosetting dental restorative resins. J.dent.Res., v.48, n.4, p.52635, Aug. 1969.

111- LEINFELDER, K.F.; RUSSELL, C.M.; MUENINGHOFF, L.A. Use of $\mathrm{Ca}(\mathrm{OH})_{2}$ for measuring microleakage. Dent. Mat., v.2, p.121-4, 1986.

112- LITKOWSKI, L.J.; MCDONALD, N.J.; SWIERCZEWSKI, M. A comparison of thermalcycling methods for evaluating microleakage. J.dent.Res., v.68, n.1, p.207, 1989. /Abstract 208/.

113- LLOYD, B.A.; McGINLEY, M.B; BROWN,W.S. Thermal stress in teeth. J.dent.Res., v.57, p.571, 1978.

114- LOUISELLE, R. J., et al., Marginal microleakage an in vivo assessment. J.Amer.dent. Ass., v.78, p.758-60, 1969.

115- MANDERS, C.A; GARCIA-GODOY, F.; BARWELL, G.M. Effect of a copal varnish, ZOE or glass ionomer cement bases on microleakage of amalgam restorations. Amer. J. Dent., v. 3, n. 2, p. 63-6, 1990.

116- MANDRAS, R.S.; RETIEF, D.H.; RUSSELL, C.M. The effects of thermal and acclusal stress on the microleakage of the Scotchbond 2 dentinal bonding system. Dent. Mat., v.7, p.637, 1991.

117- MANDRAS, R. S.; RETIEF, D.H.; RUSSELL, C. M. A quantitative method of evaluating microleakage of dentinal bonding systems. J.dent. Res., v.71, p.112, 1992. /Abstract 49/. 
118- MATOS, A.B. et al. Effects of acid etching on dentin surface: SEM morphological study. Braz. dent. J., v.8, n.1, p.35-41, 1997.

119- MARINELLI, S.M.; EICHMILLER, F. Comparing three dimensional $x$ two dimensional evaluation of microleakage in composite restorations. J.dent.Res., v.72, p.197, 1993. /Abstract.748/.

120- MARTINS, F.F.; BRYANT, R.W. A acid etching of enamel cavity walls. Cuest. Dent. J., v.29, n.5, p.308-14, Oct. 1994.

121- Mc LEAN, J.W. et al. The use of glass-ionomer cements in bonding composite resins to dentin. Brit. dent. J., v. 158, n. 11, p.410-4, June 1985.

122- MENDONÇA, M.M. Avaliação da eficiência de selantes e glazeadores na prevenção da infiltração marginal, em restaurações de resinas compostas (classe V) após a escovação com dentifrícios. Bauru, 1976. 80p. Dissertação (Mestrado) - Faculdade de Odontologia de Bauru, Universidade de São Paulo.

123- MENEGALE, C. SWARTZ, P.L.; PHILLIPS, R.W. Adaptation of restorative materials as influenced by roughness of cavity walls. J.dent.Res., v.39, n.1, p.825-35, 1960.

124- MIEARS, J.R.; CHARLTON, D.G.; HERMESCH, C.B. Effect of dentin moisture and storage time on resin bonding. Amer. J. Dent., v.8, n.2, p.80-2, Apr.1995.

125- MILLER, M. B. et al. Effect of restorative materials on microleakage of class II composites. J.Esth.Dent, v.8, n.3, p.107-13, 1996. 
126- MIRANDA JUNIOR, W.G. Avaliação “in vitro" da infiltração nas caixas proximais de pré-molares humanos restaurados com diferentes adesivos universais e resinas compostas. São Paulo, 1994. 85p. Tese (Doutorado)- Faculdade de Odontologia da Universidade de São Paulo.

127- MIYAZAKI, M. et al. Influence of thermal cycling on dentin bond strength of two-step bonding systens. Amer.J.Dent., v.11, n.3, p.118-22, Jun 1998.

128- MIXON, J. et al. Comparison of two-surface and multiple-surface scoring methodologies for in vitro microleakage studies. Dent.Mat., v.7, p.1916, 1991.

129- MJÖR, I. A. Frequency of secundary caries at various anatomical locations. Oper.Dent., v.10, n.4, p.88-92, Apr. 1985.

130- MOLL, K.; WÖRLE, P.; HALLER, B. Microleakage of class V composite restorations: effect of dye. J. dent. Res., v. 78, p. 147, 2000. Special Issue. / Abstract n. 25/

131- MOMOI, Y. et al. Gradual increases in marginal leakage of resin composite restorations with thermal stress. J.dent.Res., v.69, n.10, p.1659-63, Oct. 1990.

132- MONDELLI, A. L Avaliação da infiltração marginal em cavidades de classe II restauradas com resina composta associada a outros materiais de inserção direta. Bauru, 1999. 226p. Dissertação (Mestrado) - Faculdade de Odontologia de Bauru, Universidade de São Paulo. 
133- MORLEY, F.; STOCKWELL, P.B. A simple thermal cycling device for testing dental materials. J.Dent., v.5, n.1, p.39-41, 1977.

134- MUNKSGAARD, E.C.; IRIE, M. Dentin-polymer bond established by Gluma and tested by thermal strees Scand.J.dent.Res., v.95, n.18590, 1987.

135- MUNKSGAARD, E.C.; IRIE, M. Effect of load-cycling on bond between composite fillings tested in vitro by thermo and load cycling. $\mathbf{J}$ dent. Res., v. 64, p. 114-6, 1988.

136- MUNKSGAARD, E.C.; ITHO, K.; JORGENSEN, K.D. Dentin-polymer bond in resin fillings tested in vitro by thermo-and load cycling. J.dent.Res.; v.64, n.2, p.144-6, Feb 1985.

137- MUNKSGAARD, E.C.; HANSEN, E.K.; ASMUSSEN, E. Effect of five adhesives on resin in dentin cavities.. Scand. J. dent. Res; v.92, p.544-8, 1984.

138- NAKABAYASHI, N.; KOJIMA, K.; MASUHARA, E. The promotion of adhesion by the infiltration of monomers into tooth substrates. J.Biomed. Mater. Res., v.16, n.3, p.265-73, May 1982.

139- NAVARRO, M. F. de L.; PASCOTTO, R.C. Uso em dentística. In: Cimentos de ionômero de vidro. Artes Médicas, São Paulo, 1998. Cap.5, p. 88-150.

140- NAVARRO, M.F. de L.; PALMA ,R,G,; DEL'HOYO, R.B. O que é preciso saber a respeito de ionômero de vidro? Inovações, vantagens, e desvantagens. In: FELLER,C.; BOTTINO, M.A., coord. Atualização na clínica odontológica: a prática da clínica geral. São Paulo, Artes Médicas, 1994. Cap.4, p.61-74. 
141- NELSEN, R. J.; WOLCOTT, R. B.; PAFFENBARGER, G.C. Fluid exchange at the margins of dental restoration. J.Amer dent.Ass., v.44, n.3, p.288-95, Mar.1952.

142- OPDAM, N.J.M.; ROETERS, J.J.M.; BURGERSDIJK, R.C.W. Microleakage of class II box-type composite restorations. Amer. J. Dent., v.11, n.4, p.160-4, Aug 1998.

143- ORTEGA, R. C. S; SOUZA JÚNIOR, M. H. S.. Influência de diferentes condicionadores ácidos na resistência adesiva de uma resina composta ao esmalte. In: JORNADA ODONTOLÓGICA DE BAURU, Bauru, 1995. Anais. Bauru, FOB-USP, 1995 /Resumo n.6/

144- ORTIZ R. F.; PHILLIPS, R.W.; SWARTZ, M. S.; OSBORNE, J.W. Effect of composite resin bond agent on microleakage and bond strength. J.Prosth. Dent., v.41, n.1, p.51-7, 1979.

145- OWENS, B.M. Microleakage of cervical restorations etched with a wear organic acid. J.Canad. dent. Ass., v.63, n.6, p.445-7, June. 1997.

146- PAFFENBARGER, G.C.; NELSEN, R. J.; SWEENEY, W.T. Direct and indirect filling resins: A review of some physical and chemical properties. J.Amer. dent. Ass., v.47, p.516-24, 1953.

147- PASHLEY, D.H. Smear layer physiological considerations. Oper. Dent., v.9, p.13-29, 1984. Supplement n. 3.

148- PASHLEY, D.H.; CARVALHO, R.M. Dentin permeability and dentin adhesion. J.Dent.,v.25, n.5, p.355-72, Sept 1997.

149- PASHLEY, D.H. et al. Permeability of dentin to adhesive agents. Quintessence Int., v.24, n.9, p.618-31, 1993. 
150- PEARSON, G.L.; LONGMAN. C.M. The effect on marginal leakage, in vitro, of curing a composite material at elevated temperatures with or without marginal etching of the cavity. J.Dent., v.15, n.4, p.171-4, 1987.

151- PEREIRA, M.A. Avaliação da infiltração marginal em cavidades de Classe II restauradas com dois tipos de resinas compostas. Efeito do carregamento oclusal e de técnicas de inserção. Bauru, 1999. 130p. Dissertação (Mestrado). Faculdade de Odontologia de Bauru, Universidade de São Paulo.

152- PETERSON, E. A. PHILLIPS, R.W.; SWARTZ, M. L. A comparison of the physical properties of four restorative resins. J.Amer.dent.Ass., v.73, p.1324-36, 1966.

153- PHILLIPS, R. W. et al. Adaptation of restorations in vivo as assessed by $\mathrm{Ca}^{45}$. J Amer.dent Ass., v .62, p.9-20, Jan. 1961.

154- PICKARD, H.M.; GAYFORD, J.J. Leakage at the margins of amalgam restorations. Brit.dent.J., v. 119, n.2, p.69-80, July 1965.

155- PRATI, C. et al. Permeability and microleakage of class II resin composite restorations. J.Dent., v.22, n.1, p.49-56, 1994.

156- RAFEI, S.A.; MOORE, D. L. Marginal penetration of composite resin restorations as indicated by a tracer dye. J. prosth. Dent., v.34, n.4, p.435-9, Oct.1975.

157- RASKIN, A. et al. Microleakage in vitro tests: evaluation criteria and statistical methods. J. dent. Res., v.78, p. 353, 2000. Special Issue. /Abstract n. 1680/ 
158- RASKIN, A. et al. Microleakage in vitro testes: literature review of methodology and meta analysis. J. dent. Res., v.78, p. 521, 2000. Special Issue. /Abstract n. 3018/

159- RETIEF, D.H. The intra-oral factors affecting adhesion. J.dent.Ass. S.Afr., v.25, n.11, p.392-9, Nov.1970.

160- RETIEF, D.H Are adhesive techyniques suficient to prevent microleakage? Oper Dent., v.12, n.4, p.140-5, 1987.

161- RETIEF, D.H. Standardizing laboratory adhesion tests. Amer.J.Dent., v.4, n.5, p.231-6, Oct. 1991.

162- RETIEF, D.H. et al. Phosphoric acid as dentin etchant. Amer.J.Dent.,v.5, n.1, p.24-8, Feb. 1992.

163- RETIEF, D.H. Do adhesives prevent microleakage? Int.dent.J.,v.44, n.1, p.19-26, 1994.

164- RETIEF, D.H.; DENYS, F.R. Adhesion to enamel and dentin. Amer. J.Dent., .v.2, p.133-44,1989.

165- RETIEF, D.H.; RUTLAND, J.R.; JAMILSON, H.C. Microleakage of conventional and microfilled composite restorative systems. J.Biomed. Mater Res., v.16, n. 3, p.901-10, 1982.

166- RETIEF, D.H. WOODS, B.S.E.; JAMILSON, H.C. Effects of cavosurfaces treatment on marginal leakage in class $\mathrm{V}$ composite resin restorations. J.prosth .Dent., v.47, n.5, p.496-501, May. 1982. 
167- RIGSBY, D.F. et al. Marginal leakage and marginal gap dimensions of three dentinal bonding systems. Amer. J. Dent., v.3, n.6, p.289-94, Dec. 1990.

168- RIGSBY, D. F. et al. Effect of axial load and temperature on microleakage of resin restorations. Amer.J.Dent., v.5, n.3, p.155-9, June 1992.

169- ROSE, E .E. et al . Direct resin filling materials: coefficient of thermal expansion and water sorption of polymethyl metacrylate. J.dent . Res ,v.34, n.4, p 589-96, 1955.

170- ROSSOMANDO, K.J.; WENDT, S.L. Thermocycling and dwell times in microleakage evaluation for restoration for bonded restorations. Dent. Mat., v.11, p.74-51, Jan. 1995.

171- ROUDHOUSE, R.H.; WEISS, M.E.; LEONARD, L. Penetration around the margins of restorations: 1- Review and experiments. J.canad. dent. Ass., v.33, n.12, p.680-9, 1967.

172- ROULET, J.F. Marginal integrity clinical significance. J.Dent., v.22, Supplement., p.S9-S12, 1994.

173- RUSSO, M. Método para avaliação quantitativa dos resultados da infiltração marginal de radioisótopo $\left({ }^{131} \mathrm{l} \mathrm{Na}\right)$ em restaurações dentais. Rev.bras.Odont., v.25, n. 153, p.295-301, Set./Out.1968.

174- SCOTT, G. R. The relationship between carabelli's trait and the protostylid. J.dent. Res., v.57, n.4, p.571-82, Apr. 1978. 
175- SCHUCKAR, M.; GEURTSEN, W. Proximo-cervical adaptation of class II-composite restorations after thermocycling: a quantitative and qualitative study. J.oral Rehab., v.24, n.10, p.766-75, Oct. 1997.

176- SCHUURS, A H.B. et al. Endodontic leakage studies reconsidered. Part II. Statistical aspects. Int. Endod. J., v. 26, p. 44-52, 1993.

177- SELTZER, S. Penetration of microorgamisms between the tooth and direct resin fillings. J.Amer.dent.Ass., v.51, p.560-6, 1955.

178- SHORTALL, A. C. Microleakage, marginal adaptation and composite resin restorations. Brit.dent.J., v.153, n.21, p.223-7, 1982.

179- SHORTALL, A.C.; FAYYAD, M.A.; WILLIAMS, J.D. Marginal seal of injection-molded ceramic crows cemented with three adhesive systems. J.prosth.Dent., v.61, n.1, p.24-7, Jan.1989.

180- SILVA FILHO, F.P.M.; SIMÕES, M.A. Contribuição ao estudo das infiltrações marginais nas restaurações com resinas. Efeitos do tipo de resina do tempo de imersão em água e da ciclagem térmica. Rev. Ass. paul. cirurg.Dent., v.35, n.4, p.326-7, jul./ago. 1981.

181- SMITH, L. A. et al. Microleakage of two dentinal bonding restorative systems. J.dent.Res., v.67, p. 309, 1988 /Abstract 1568/.

182- SOUZA JUNIOR, M. H. et al. Avaliação da infiltração marginal em esmalte e cemento em cavidades classe II MOD restauradas com cinco sistemas adesivos. Rev Fac.Odont.USP, v.5, n.2, p.140-5, jul/dez.1991. 
183- SPIERINGS, A.M.; VARST, V. D.; PETERS, C.R.B. Modeling of in vivo thermal loading conditions in the oral cavity. J. dent. Res., v.65, p.777, 1986. /Abstract 463/.

184- STANINEC, M. et al. Interfacial space, marginal leakage, and enamel cracks around composite resins. Oper Dent., v.11, p.14-24, 1986.

185- STANINEC, M.; KAWAKAMI, M. Adhesion and microleakage tests of a new dentin bonding system. Dent.Mat, v.9, p.204-8, May 1993.

186- STEWART, G.P., BALDA, R.A.; NORMAN, R.D. The effects of mechanical loading on marginal integrity of composite restorations. Dent.Mat., v.2, p.151-2,1986.

187- SWARTZ, M.; PHILLIPS, R.W. In vitro studies on the marginal leakage of restorative materials. J.Amer.dent.Ass., v.62, p.141-51, Feb. 1961.

188- SWIFT, E.J.; DENEHY, G.E, BECK, M.D. Use of phosphoric acid etchants with Scotchbond Multi-Purpose. Amer.J.Dent., v.6, n.2, p.8890, Apr. 1993.

189- TANI, Y; BUONOCORE, M. G. Marginal leakage and penetration of basic fucsin dye in anterior restorative materials. J.Amer dent. Ass., v.78, n.3, p.542-8, Mar.1969.

190- TAY, F. R. et al. A method for microleakage evaluation along the dentin/restorative interface. Amer.J.Dent., v.8, n.2, p.105-8, Apr. 1995.

191- TAYLOR, L.G.; LYNCH, E. Microleakage. J.Dent.,v.20, n.1, p.3-10, Jan.1992. 
192- THORDRUP, M.; ISIDOR, F.; HORSTED-BILDSLEV, P. Comparison of marginal fit and microleakage of ceramic and composite inlays an in vitro study. J.Dent., v.22, n.3, p.147-53, June 1994.

193- TITLEY, K. C. et al. An SEM examination of etched dentin and the structure of the hybrid layer. J.Canad.Dent.Ass., v.61, n.10, p.887-94, Oct. 1995.

194- TITLEY, K. C. et al. The composition and ultrastructure of resin tags in etched dentin. Amer. J. Dent., v.8, n.5, p.224-30, Oct. 1995.

195- TORSTENSEN, B.; BRÄNNSTRÖM, M. Contraction gap under composite resin restorations: effect of hygroscopic expansion and thermal stress. Oper. Dent., v.13, n.1, p.24-31, Jan./Feb. 1988.

196- TROWBRIDGE, H. O. Model systems for determining biologic effects of microleakage. Oper. Dent., v.12, p.164-72, 1987.

197- VANMEERBEEK, B. et al. Correlative transmission electron microscopy examination of non desmineralized and desmineralized resin-dentin interfaces formed by two dentin adhesive systems. J.dent.Res., v.75, n.3, p.879-88, Mar.1996.

198- VERONEZI, M.C.; PAZIM, M.S.L.; ZAGO, P.H.; CARDOSO, P.C. Influence of superficial sealant on the marginal leakage of resin composite restorations. J. dent. Res., v. 79, p. 355, 2000. /Abstract1690/.

199- WAINWRIGHT, W.W. The aplication of radioisótopes in dentistry. Rev.Chicago dent.Soc., v.26, p.15,1953. 
200- WATANABE, I.; NAKABAYASHI, N. Measurement methods for adhesion to dentine: the current status in Japan. J.Dent., v.22, n.2, p.67-72, Apr. 1994.

201- WELSH, E. L.; HEMBREE, J.H. Microleakage at the gengival wall with four class $\mathrm{V}$ anterior restorative materials. J. prosth. Dent., v.54, n.3, p.370-2, Sep. 1985.

202- WENDT, S.L.; Mc INNES, P.M.; DICKINSON, G.L. The effect of thermocycling in microleakage analysis. Dent.Mat., v.8, p.181-4, May 1992.

203- WILLIAMS, V.D.; SVARE, C.W. Duration of tooth storage vs. potential for adhesive bonding. J.dent.Res., v.63, p.179, 1984. /Abstract 81/.

204- YAMAUTI,M. Avaliação da infiltração marginal em restaurações de resina composta empregando-se diferentes técnicas de inserção e de ativação da polimerização do material. Bauru, 1999. 141p. Dissertação (Mestrado) - Faculdade de Odontologia de Bauru, Universidade de São Paulo.

205- YEARN, J. A. Factors affecting cure of visible light activated composite. Int. dent. J., v.35, n.3, p.218-25, Sept. 1985.

206- YAP, A.U. J. Resin-modified glass ionomer cements: a comparison of water sorption charecteristics. Biomaterials, v.17, n.19, p. 1897-1900, 1996.

207- ZANDER, H.A. Pulp response to restorative materials. J. amer. dent. Ass., v. 59, p.911-4, 1959. 
ABSTRACT 


\section{ABSTRACT}

Marginal integrity is an important parameter to evaluate the longevity of a restorative material since that caries recurrence are related to the formation of a gap between teeth and restorative material. Microleakage is defined as the penetration of bacteria, fluids, molecules or ions between the cavity wall and the restorative material. Microleakage of composite resin restorations is related to the polimerization shrinkage, mastigatory stress, and the linear thermal expansion coeficient which lead the rupture of marginal sealing. There are a number of methods to test the sealing property of in vivo and in vitro restorations. However, the accomplishment of those tecniques are not easy. One of the difficulties of in vitro studies, is the reproduction of the clinical conditions to which these materials are subjected as the introral thermal changes. The laboratory process that reproduces these changes is named thermocycling, and it is defined as the in vitro process that submmits the tooth and the restoration to extreme temperatures compatible to the ones occuring in the oral cavity. The purpose of this study was to verify the influence of the cycles number on the thermocycling process for assessing the marginal microleakage of composite resin restorations as well as to compare the qualitative (scores) and quantitative (linear and area measurements) evaluation methods of the specimens. Circular cavities were prepared in 76 premolars, totally localized in cementum and/or dentine and restored with the Scothbond Multipurpose Plus / Z-100 system. The teeth were stored in distilled water at $37^{\circ} \mathrm{C}$ for 24 hours than polished and divided into four groups:

- Group 1- not submitted to thermocycling

- Group 2- submitted to 100 cycles

- Group 3- submitted to 200 cycles

- Group 4- submitted to 1000 cycles 
Thermocycling was processed between $5^{\circ} \mathrm{C}$ and $55^{\circ} \mathrm{C}$ with dwell time of 15 seconds in each bath. To avoid dye penetration in undesirable areas, the teeth were prepared with retrograde amalgams and coated with two layers of nail polish to within $1 \mathrm{~mm}$ of the restorations margins.

The teeth were stored in $0,5 \%$ fuchsin solution, $37^{\circ} \mathrm{C}$ for 24 hours. After this period, the specimens were totally embedded in polystirenic resin to be sectioned. Approximately 4 sections were made from each specimen. These sections were evaluated by both quantitative and qualitative methods, and then the results were statistically assessed. On the basis of this analysis it was concluded that:

- Thermocycling, under the conditions of this study did not influenced ststisticslly the microleakage of composite resin restorations.

- The qualitative (scores) and quantitatives (linear and area) reading methodologies to measure dye penetration were equivalent in the evaluations of the mean values and the maximum values of the dye penetration. 


\section{ANEXOS}

Resultados individuais dos espécimes de cada grupo e dos diferentes métodos de leitura utilizados para medir a microinfiltração.

PROGRAMA IMAGE TOOL

LEITURA LINEAR (mm)

GRUPO DE NENHUM CICLO

CORPO 1

\begin{tabular}{|c|c|c|}
\hline & MARGEM GENGIVAL & MARGEM OCLUSAL \\
\hline Zero1.1a & 0 & 0 \\
\hline Zero $1.1 \mathrm{~b}$ & 0 & 0 \\
\hline Zero $1.2 \mathrm{a}$ & 0 & 0 \\
\hline Zero $1.2 \mathrm{~b}$ & 0 & 0 \\
\hline Zero $1.3 \mathrm{a}$ & 0 & 0 \\
\hline Zero $1.3 \mathrm{~b}$ & 0 & 0 \\
\hline Zero $1.4 \mathrm{a}$ & 0 & 0 \\
\hline Zero $1.4 \mathrm{~b}$ & 0 & 0 \\
\hline
\end{tabular}

\section{CORPO 2}

\begin{tabular}{|c|c|c|}
\hline & MARGEM GENGIVAL & MARGEM OCLUSAL \\
\hline Zero2.1a & 0 & 0 \\
\hline Zero 2.1b & 0 & 0 \\
\hline Zero 2.2a & 0 & 0 \\
\hline Zero 2.2b & 0 & 0 \\
\hline Zero 2.3a & 0 & 0 \\
\hline Zero 2.3b & 0 & 0 \\
\hline Zero 2.4a & 0 & 0 \\
\hline Zero 2.4b & 0 & 0 \\
\hline
\end{tabular}

CORPO 3

\begin{tabular}{|c|c|c|}
\hline & MARGEM GENGIVAL & MARGEM OCLUSAL \\
\hline Zero3.1a & 0 & 0 \\
\hline Zero 3.1b & 0 & 0 \\
\hline Zero 3.2a & 0 & 0 \\
\hline Zero 3.2b & 0 & 0 \\
\hline Zero 3.3a & 0 & 0 \\
\hline Zero 3.3b & 0 & 0 \\
\hline Zero 3.4a & 0 & 0 \\
\hline Zero 3.4b & 0 & 0 \\
\hline
\end{tabular}




\section{CORPO 4}

\begin{tabular}{|c|c|c|}
\hline & MARGEM GENGIVAL & MARGEM OCLUSAL \\
\hline Zero4.1a & 0 & 0 \\
\hline Zero 4.1b & 0 & 0 \\
\hline Zero 4.2a & 0 & 0 \\
\hline Zero 4.2b & 0 & 0 \\
\hline Zero 4.3a & 0 & 0 \\
\hline Zero 4.3b & 0 & 0 \\
\hline Zero 4.4a & 0 & 0 \\
\hline Zero 4.4b & 0 & 0 \\
\hline
\end{tabular}

\section{CORPO 5}

\begin{tabular}{|c|c|c|}
\hline & MARGEM GENGIVAL & MARGEM OCLUSAL \\
\hline Zero5.1a & 0 & 0 \\
\hline Zero 5.1b & 0 & 0 \\
\hline Zero 5.2a & 0 & 0 \\
\hline Zero 5.2b & 0 & 0 \\
\hline Zero 5.3a & 0 & 0 \\
\hline Zero 5.3b & 0 & 0 \\
\hline Zero 5.4a & 0 & 0 \\
\hline Zero 5.4b & 0 & 0 \\
\hline
\end{tabular}

CORPO 6

\begin{tabular}{|c|c|c|}
\hline & MARGEM GENGIVAL & MARGEM OCLUSAL \\
\hline Zero 6.1a & 0 & 0 \\
\hline Zero 6.1b & 0 & 0 \\
\hline Zero 6.2a & 0 & 0 \\
\hline Zero 6.2b & 0 & 0 \\
\hline Zero 6.3a & 0 & 0 \\
\hline Zero 6.3b & 0 & 0 \\
\hline Zero 6.4a & 0 & 0 \\
\hline Zero 6.4b & 0 & 0 \\
\hline
\end{tabular}

CORPO 7

\begin{tabular}{|c|c|c|}
\hline & MARGEM GENGIVAL & MARGEM OCLUSAL \\
\hline Zero 7.1a & 0 & 0 \\
\hline Zero 7.1b & 0 & 0 \\
\hline Zero 7.2a & 0 & 0 \\
\hline Zero 7.2b & 0 & 0 \\
\hline Zero 7.3a & 0 & 0 \\
\hline Zero 7.3b & 0 & 0 \\
\hline Zero 7.4a & 0 & 0 \\
\hline Zero 7.4b & 0 & 0 \\
\hline
\end{tabular}




\section{CORPO 8}

\begin{tabular}{|c|c|c|}
\hline & MARGEM GENGIVAL & MARGEM OCLUSAL \\
\hline Zero 8.1a & 0 & 0 \\
\hline Zero 8.1b & 0 & 0 \\
\hline Zero 8.2a & 0 & 0 \\
\hline Zero 8.2b & 0 & 0 \\
\hline Zero 8.3a & 0 & 0 \\
\hline Zero 8.3b & 0 & 0 \\
\hline Zero 8.4a & 0 & 0 \\
\hline Zero 8.4b & 0 & 0 \\
\hline
\end{tabular}

\section{CORPO 9}

\begin{tabular}{|c|c|c|}
\hline & MARGEM GENGIVAL & MARGEM OCLUSAL \\
\hline Zero 9.1a & 0 & 0 \\
\hline Zero 9.1b & 0 & 0 \\
\hline Zero 9.2a & 0 & 0 \\
\hline Zero 9.2b & 0 & 0 \\
\hline Zero 9.3a & 0 & 0 \\
\hline Zero 9.3b & 0 & 0 \\
\hline Zero 9.4a & 0 & 0 \\
\hline Zero 9.4b & 0 & 0 \\
\hline
\end{tabular}

\section{CORPO 10}

\begin{tabular}{|c|c|c|}
\hline & MARGEM GENGIVAL & MARGEM OCLUSAL \\
\hline Zero 10.1a & 0-Sem restauração & 0-Sem restauração \\
\hline Zero 10.1b & 0-Sem restauração & 0-Sem restauração \\
\hline Zero 10.2a & 0,31 & 0,51 \\
\hline Zero 10.2b & 0,16 & 0,52 \\
\hline Zero 10.3a & 0,15 & 0,34 \\
\hline Zero 10.3b & 0,22 & 0,52 \\
\hline Zero 10.4a & 0 & 0,43 \\
\hline Zero 10.4b & 0 & 0,88 \\
\hline
\end{tabular}

\section{CORPO 11}

\begin{tabular}{|c|c|c|}
\hline & MARGEM GENGIVAL & MARGEM OCLUSAL \\
\hline Zero 11.1a & 0-Sem restauração & 0-Sem restauração \\
\hline Zero 11.1b & 0-Sem restauração & 0-Sem restauração \\
\hline Zero 11.2a & 0 & 0,27 \\
\hline Zero 11.2b & 0 & 0,26 \\
\hline Zero 11.3a & 0 & 0,21 \\
\hline Zero 11.3b & 0 & 0,21 \\
\hline Zero 11.4a & 0 & 0,46 \\
\hline Zero 11.4b & 0 & 0,15 \\
\hline
\end{tabular}




\section{CORPO 12}

\begin{tabular}{|c|c|c|}
\hline & MARGEM GENGIVAL & MARGEM OCLUSAL \\
\hline Zero 12.1a & 0,26 & 0 \\
\hline Zero 12.1b & 0,12 & 0 \\
\hline Zero 12.2a & 0,17 & 0 \\
\hline Zero 12.2b & 0,32 & 0 \\
\hline Zero 12.3a & 0,54 & 0 \\
\hline Zero 12.3b & 0,47 & - \\
\hline Zero 12.4a & - & - \\
\hline Zero 12.4b & - & 0 \\
\hline
\end{tabular}

\section{CORPO 13}

\begin{tabular}{|c|c|c|}
\hline & MARGEM GENGIVAL & MARGEM OCLUSAL \\
\hline Zero 13.1a & 0 & 0 \\
\hline Zero 13.1b & 0 & 0 \\
\hline Zero 13.2a & 0 & 0 \\
\hline Zero 13.2b & 0 & 0 \\
\hline Zero 13.3a & 0 & 0 \\
\hline Zero 13.3b & 0 & 0 -sem restauração \\
\hline Zero 13.4a & 0-sem restauração & 0-sem restauração \\
\hline Zero 13.4b & 0-sem restauração & 0 \\
\hline
\end{tabular}

\section{CORPO 14}

\begin{tabular}{|c|c|c|}
\hline & MARGEM GENGIVAL & MARGEM OCLUSAL \\
\hline Zero 14.1a & 0-sem restauração & 0-sem restauração \\
\hline Zero 14.1b & 0-sem restauração & 0 -sem restauração \\
\hline Zero 14.2a & 0 & 0 \\
\hline Zero 14.2b & 0 & 0,34 \\
\hline Zero 14.3a & 0 & 0,37 \\
\hline Zero 14.3b & 0 & 0 -sem restauração \\
\hline Zero 14.4a & 0-sem restauração & 0-sem restauração \\
\hline Zero 14.4b & 0-sem restauração & \\
\hline
\end{tabular}

\section{CORPO 15}

\begin{tabular}{|c|c|c|}
\hline & MARGEM GENGIVAL & MARGEM OCLUSAL \\
\hline Zero 15.1a & 0 & 0 \\
\hline Zero 15.1b & 0,17 & 0 \\
\hline Zero 15.2a & 0 & 0 \\
\hline Zero 15.2b & 0 & 0 \\
\hline Zero 15.3a & 0 & 0 \\
\hline Zero 15.3b & 0 & - \\
\hline Zero 15.4a & - & - \\
\hline Zero 15.4b & - & 0 \\
\hline
\end{tabular}




\section{CORPO 16}

\begin{tabular}{|c|c|c|}
\hline & MARGEM GENGIVAL & MARGEM OCLUSAL \\
\hline Zero 16.1a & 0 & 0 \\
\hline Zero 16.1b & 0 & 0 \\
\hline Zero 16.2a & 0,26 & 0 \\
\hline Zero 16.2b & 0 & - \\
\hline Zero 16.3a & - & - \\
\hline Zero 16.3b & - & - \\
\hline Zero 16.4a & - & - \\
\hline Zero 16.4b & - & 0 \\
\hline
\end{tabular}

\section{CORPO 17}

\begin{tabular}{|c|c|c|}
\hline & MARGEM GENGIVAL & MARGEM OCLUSAL \\
\hline Zero 17.1a & 0,39 & 0 \\
\hline Zero 17.1b & 0,18 & 0 \\
\hline Zero 17.2a & 0,23 & 0 \\
\hline Zero 17.2b & 0,19 & 0 \\
\hline Zero 17.3a & 0 & 0 \\
\hline Zero 17.3b & 0 & - \\
\hline Zero 17.4a & - & - \\
\hline Zero 17.4b & - & 0 \\
\hline
\end{tabular}

\section{CORPO 18}

\begin{tabular}{|c|c|c|}
\hline & MARGEM GENGIVAL & MARGEM OCLUSAL \\
\hline Zero 18.1a & 0 & 0 \\
\hline Zero 18.1b & 0,13 & 0 \\
\hline Zero 18.2a & 0 & 0 \\
\hline Zero 18.2b & 0 & 0 \\
\hline Zero 18.3a & 0,80 & 0 \\
\hline Zero 18.3b & 1,1 & - \\
\hline Zero 18.4a & - & - \\
\hline Zero 18.4b & - & 0 \\
\hline
\end{tabular}

\section{CORPO 19}

\begin{tabular}{|c|c|c|}
\hline & MARGEM GENGIVAL & MARGEM OCLUSAL \\
\hline Zero 19.1a & 0-sem restauração & 0-sem restauração \\
\hline Zero 19.1b & 0-sem restauração & 0-sem restauração \\
\hline Zero 19.2a & 0,64 & 0,79 \\
\hline Zero 19.2b & 0,42 & 0,58 \\
\hline Zero 19.3a & 0 & 0 \\
\hline Zero 19.3b & 0 & 0 \\
\hline Zero 19.4a & 0 & 0,89 \\
\hline Zero 19.4b & 0 & 0,14 \\
\hline
\end{tabular}




\section{GRUPO DE 100 CICLOS}

\section{CORPO 1}

\begin{tabular}{|c|c|c|}
\hline & MARGEM GENGIVAL & MARGEM OCLUSAL \\
\hline Cem $1.2 \mathrm{a}$ & Pouca resina & Pouca resina \\
\hline Cem $1.2 \mathrm{~b}$ & Pouca resina & 0 \\
\hline Cem 1.3a & 3,52 & 0 \\
\hline Cem 1.3b & 4,5 & 0 \\
\hline Cem.1.4a & 5,18 & 0 \\
\hline Cem 1.4b & 5,18 & 0 \\
\hline Cem 1.5a & 4,18 & 0 \\
\hline Cem $1.5 \mathrm{~b}$ & 3,53 & \\
\hline
\end{tabular}

\section{CORPO 2}

\begin{tabular}{|c|c|c|}
\hline & MARGEM GENGIVAL & MARGEM OCLUSAL \\
\hline Cem 2.1a & 0,95 & 0 \\
\hline Cem 2.1b & 1,48 & 0 \\
\hline Cem 2.2a & 4,56 & 0 \\
\hline Cem 2.2b & 4,48 & 0 \\
\hline Cem.2.3a & 4,29 & 0 \\
\hline Cem 2.3b & 4,02 & - \\
\hline Cem 2.4a & - & - \\
\hline Cem 2.4b & - & \\
\hline
\end{tabular}

\section{CORPO 3}

\begin{tabular}{|c|c|c|}
\hline & MARGEM GENGIVAL & MARGEM OCLUSAL \\
\hline Cem 3.1a & Pouca resina & Pouca resina \\
\hline Cem 3.1b & 1,11 & 0 \\
\hline Cem 3.2aa & 0,76 & 0 \\
\hline Cem 3.2b & 0,85 & 0 \\
\hline Cem.3.3a & 0,59 & 0 \\
\hline Cem 3.3b & 0,54 & 0 \\
\hline Cem 3.4a & 0,18 & 0 \\
\hline Cem 3.4b & 0 & 0 \\
\hline
\end{tabular}

\section{CORPO 4}

\begin{tabular}{|c|c|c|}
\hline & MARGEM GENGIVAL & MARGEM OCLUSAL \\
\hline Cem 4.1a & 0 & 0 \\
\hline Cem 4.1b & 0 & 0 \\
\hline Cem 4.2a & 0 & 0 \\
\hline Cem 4.2b & 0 & 0 \\
\hline Cem.4.3a & 0 & 0 \\
\hline Cem 4.3b & 0 & 0 \\
\hline Cem 4.4a & 0 & 0 \\
\hline Cem 4.4b & 0 & 0 \\
\hline
\end{tabular}


CORPO 5

\begin{tabular}{|c|c|c|}
\hline & MARGEM GENGIVAL & MARGEM OCLUSAL \\
\hline Cem 5.1a & 2,08 & 0,14 \\
\hline Cem 5.1b & 3,97 & 0,13 \\
\hline Cem 5.2aa & 1,43 & 0 \\
\hline Cem 5.2b & 1,29 & 0 \\
\hline Cem.5.3aa & 1,45 & 0 \\
\hline Cem 5.3b & 0,51 & 0 \\
\hline Cem 5.4aaa & - & - \\
\hline Cem 5.4b & - & - \\
\hline
\end{tabular}

\section{CORPO 6}

\begin{tabular}{|c|c|c|}
\hline & MARGEM GENGIVAL & MARGEM OCLUSAL \\
\hline Cem 6.1a & Sem restauração & Sem restauração \\
\hline Cem 6.1b & Sem restauração & Sem restauração \\
\hline Cem 6.2a & 2,43 & 0 \\
\hline Cem 6.2b & 2,47 & 0 \\
\hline Cem.6.3a & 2,79 & 0 \\
\hline Cem 6.3b & 3,05 & 0 \\
\hline Cem 6.4a & - & - \\
\hline Cem 6.4b & - & - \\
\hline
\end{tabular}

\section{CORPO 7}

\begin{tabular}{|c|c|c|}
\hline & MARGEM GENGIVAL & MARGEM OCLUSAL \\
\hline Cem 7.1a & 0-Corante entra $\mathrm{p} / 1 \mathrm{~mm}$ & Sem restauração \\
\hline Cem 7.1b & 0-Corante entra $\mathrm{p} / 1 \mathrm{~mm}$ & Sem restauração \\
\hline Cem 7.2a & 0-Corante entra $\mathrm{p} / 1 \mathrm{~mm}$ & 0 \\
\hline Cem 7.2b & 0-Corante entra $\mathrm{p} / 1 \mathrm{~mm}$ & 0 \\
\hline Cem.7.3a & 0-Corante entra $\mathrm{p} / 1 \mathrm{~mm}$ & 0,74 \\
\hline Cem 7.3b & 0-Corante entra $\mathrm{p} / 1 \mathrm{~mm}$ & 0 \\
\hline Cem 7.4a & 0-Corante entra $\mathrm{p} / 1 \mathrm{~mm}$ & 0 \\
\hline Cem 7.4b & 0-Corante entra $\mathrm{p} / 1 \mathrm{~mm}$ & 0 \\
\hline
\end{tabular}

\section{CORPO 8}

\begin{tabular}{|c|c|c|}
\hline & MARGEM GENGIVAL & MARGEM OCLUSAL \\
\hline Cem 7.1a & 0-Corante entra $\mathrm{p} / 1 \mathrm{~mm}$ & 0-Corante entra $\mathrm{p} / 1 \mathrm{~mm}$ \\
\hline Cem 7.1b & 0-Corante entra $\mathrm{p} / 1 \mathrm{~mm}$ & 0-Corante entra $\mathrm{p} / 1 \mathrm{~mm}$ \\
\hline Cem 7.2a & 0-Corante entra $\mathrm{p} / 1 \mathrm{~mm}$ & 0-Corante entra $\mathrm{p} / 1 \mathrm{~mm}$ \\
\hline Cem 7.2b & 0-Corante entra $\mathrm{p} / 1 \mathrm{~mm}$ & 0-Corante entra $\mathrm{p} / 1 \mathrm{~mm}$ \\
\hline Cem.7.3a & 0-Corante entra $\mathrm{p} / 1 \mathrm{~mm}$ & 0-Corante entra $\mathrm{p} / 1 \mathrm{~mm}$ \\
\hline Cem 7.3b & 0-Corante entra $\mathrm{p} / 1 \mathrm{~mm}$ & 0-Corante entra $\mathrm{p} / 1 \mathrm{~mm}$ \\
\hline Cem 7.4a & 0-Corante entra $\mathrm{p} / 1 \mathrm{~mm}$ & 0-Corante entra $\mathrm{p} / 1 \mathrm{~mm}$ \\
\hline Cem 7.4b & 0-Corante entra $\mathrm{p} / 1 \mathrm{~mm}$ & 0-Corante entra $\mathrm{p} / 1 \mathrm{~mm}$ \\
\hline
\end{tabular}


CORPO 9

\begin{tabular}{|c|c|c|}
\hline & MARGEM GENGIVAL & MARGEM OCLUSAL \\
\hline Cem 9.1a & 0 & 0 \\
\hline Cem 9.1b & 0 & 0 \\
\hline Cem 9.2a & 0,57 & 0 \\
\hline Cem 9.2b & 0,62 & 0 \\
\hline Cem.9.3a & 0,36 & 0 \\
\hline Cem 9.3b & 0,61 & - \\
\hline Cem 9.4a & - & - \\
\hline Cem 9.4b & - & \\
\hline
\end{tabular}

\section{CORPO 10}

\begin{tabular}{|c|c|c|}
\hline & MARGEM GENGIVAL & MARGEM OCLUSAL \\
\hline Cem 10.1a & 0-Corante entra $\mathrm{p} / 1 \mathrm{~mm}$ & 0-Corante entra $\mathrm{p} / 1 \mathrm{~mm}$ \\
\hline Cem 10.1b & 0-Corante entra $\mathrm{p} / 1 \mathrm{~mm}$ & 0-Corante entra $\mathrm{p} / 1 \mathrm{~mm}$ \\
\hline Cem 10.2a & 0-Corante entra $\mathrm{p} / 1 \mathrm{~mm}$ & 0-Corante entra $\mathrm{p} / 1 \mathrm{~mm}$ \\
\hline Cem 10.2b & 0-Corante entra $\mathrm{p} / 1 \mathrm{~mm}$ & 0-Corante entra $\mathrm{p} / 1 \mathrm{~mm}$ \\
\hline Cem.10.3a & 0-Corante entra $\mathrm{p} / 1 \mathrm{~mm}$ & 0-Corante entra $\mathrm{p} / 1 \mathrm{~mm}$ \\
\hline Cem 10.3b & 0-Corante entra $\mathrm{p} / 1 \mathrm{~mm}$ & 0-Corante entra $\mathrm{p} / 1 \mathrm{~mm}$ \\
\hline Cem 10.4a & 0-Corante entra $\mathrm{p} / 1 \mathrm{~mm}$ & 0-Corante entra $\mathrm{p} / 1 \mathrm{~mm}$ \\
\hline Cem 10.4b & 0-Corante entra $\mathrm{p} / 1 \mathrm{~mm}$ & 0-Corante entra $\mathrm{p} / 1 \mathrm{~mm}$ \\
\hline
\end{tabular}

\section{CORPO 11}

\begin{tabular}{|c|c|c|}
\hline & MARGEM GENGIVAL & MARGEM OCLUSAL \\
\hline Cem 11.1a & 0-Corante entra $\mathrm{p} / 1 \mathrm{~mm}$ & -Corante entra $\mathrm{p} / 1 \mathrm{~mm}$ \\
\hline Cem 11.1b & 0-Corante entra $\mathrm{p} / 1 \mathrm{~mm}$ & 0-Corante entra $\mathrm{p} / 1 \mathrm{~mm}$ \\
\hline Cem 11.2a & 0-Corante entra $\mathrm{p} / 1 \mathrm{~mm}$ & 0-Corante entra $\mathrm{p} / 1 \mathrm{~mm}$ \\
\hline Cem 11.2b & 0-Corante entra $\mathrm{p} / 1 \mathrm{~mm}$ & 0-Corante entra $\mathrm{p} / 1 \mathrm{~mm}$ \\
\hline Cem.11.3a & 0-Corante entra $\mathrm{p} / 1 \mathrm{~mm}$ & 0-Corante entra $\mathrm{p} / 1 \mathrm{~mm}$ \\
\hline Cem 11.3b & 0-Corante entra $\mathrm{p} / 1 \mathrm{~mm}$ & 0-Corante entra $\mathrm{p} / 1 \mathrm{~mm}$ \\
\hline Cem 11.4a & 0-Corante entra $\mathrm{p} / 1 \mathrm{~mm}$ & 0-Corante entra $\mathrm{p} / 1 \mathrm{~mm}$ \\
\hline Cem 11.4b & 0-Corante entra $\mathrm{p} / 1 \mathrm{~mm}$ & 0-Corante entra $\mathrm{p} / 1 \mathrm{~mm}$ \\
\hline
\end{tabular}

\section{CORPO 12}

\begin{tabular}{|c|c|c|}
\hline & MARGEM GENGIVAL & MARGEM OCLUSAL \\
\hline Cem 12.1a & 0-Corante entra p/ 1mm & 0-Corante entra $\mathrm{p} / 1 \mathrm{~mm}$ \\
\hline Cem 12.1b & 0-Corante entra p/ 1mm & 0-Corante entra $\mathrm{p} / 1 \mathrm{~mm}$ \\
\hline Cem 12.2a & 0-Corante entra $\mathrm{p} / 1 \mathrm{~mm}$ & 0-Corante entra $\mathrm{p} / 1 \mathrm{~mm}$ \\
\hline Cem 12.2b & 0-Corante entra $\mathrm{p} / 1 \mathrm{~mm}$ & 0-Corante entra $\mathrm{p} / 1 \mathrm{~mm}$ \\
\hline Cem.12.3a & 0-Corante entra $\mathrm{p} / 1 \mathrm{~mm}$ & 0-Corante entra $\mathrm{p} / 1 \mathrm{~mm}$ \\
\hline Cem 12.3b & 0-Corante entra $\mathrm{p} / 1 \mathrm{~mm}$ & 0-Corante entra $\mathrm{p} / 1 \mathrm{~mm}$ \\
\hline Cem 12.4a & 0-Corante entra p/ 1mm & 0-Corante entra $\mathrm{p} / 1 \mathrm{~mm}$ \\
\hline Cem 12.4b & 0-Corante entra $\mathrm{p} / 1 \mathrm{~mm}$ & 0-Corante entra $\mathrm{p} / 1 \mathrm{~mm}$ \\
\hline
\end{tabular}


CORPO 13

\begin{tabular}{|c|c|c|}
\hline & MARGEM GENGIVAL & MARGEM OCLUSAL \\
\hline Cem 13.1a & 0-Corante entra $\mathrm{p} / 1 \mathrm{~mm}$ & 0-Corante entra $\mathrm{p} / 1 \mathrm{~mm}$ \\
\hline Cem 13.1b & 0-Corante entra $\mathrm{p} / 1 \mathrm{~mm}$ & 0-Corante entra $\mathrm{p} / 1 \mathrm{~mm}$ \\
\hline Cem 13.2a & 0-Corante entra $\mathrm{p} / 1 \mathrm{~mm}$ & 0-Corante entra $\mathrm{p} / 1 \mathrm{~mm}$ \\
\hline Cem 13.2b & 0-Corante entra $\mathrm{p} / 1 \mathrm{~mm}$ & 0-Corante entra $\mathrm{p} / 1 \mathrm{~mm}$ \\
\hline Cem.13.3a & 0-Corante entra $\mathrm{p} / 1 \mathrm{~mm}$ & 0-Corante entra $\mathrm{p} / 1 \mathrm{~mm}$ \\
\hline Cem 12.3b & 0-Corante entra $\mathrm{p} / 1 \mathrm{~mm}$ & 0-Corante entra $\mathrm{p} / 1 \mathrm{~mm}$ \\
\hline Cem 12.4a & 0-Corante entra $\mathrm{p} / 1 \mathrm{~mm}$ & 0-Corante entra $\mathrm{p} / 1 \mathrm{~mm}$ \\
\hline Cem 12.4b & 0-Corante entra $\mathrm{p} / 1 \mathrm{~mm}$ & 0-Corante entra $\mathrm{p} / 1 \mathrm{~mm}$ \\
\hline
\end{tabular}

\section{CORPO 14}

\begin{tabular}{|c|c|c|}
\hline & MARGEM GENGIVAL & MARGEM OCLUSAL \\
\hline Cem 14.1a & 1,79 & 0 \\
\hline Cem 14.1b & 2,41 & 0 \\
\hline Cem 14.2a & 2,50 & 0 \\
\hline Cem 14.2b & 3,05 & 0 \\
\hline Cem.14.3a & 3,40 & 0 \\
\hline Cem 14.3b & 3,23 & 0 \\
\hline Cem 14.4a & - & - \\
\hline Cem $14.4 \mathrm{~b}$ & - & - \\
\hline
\end{tabular}

\section{CORPO 15}

\begin{tabular}{|c|c|c|}
\hline & MARGEM GENGIVAL & MARGEM OCLUSAL \\
\hline Cem 15.1a & 0-Corante entra $\mathrm{p} / 1 \mathrm{~mm}$ & 0-Corante entra $\mathrm{p} / 1 \mathrm{~mm}$ \\
\hline Cem 15.1b & 0-Corante entra $\mathrm{p} / 1 \mathrm{~mm}$ & 0-Corante entra $\mathrm{p} / 1 \mathrm{~mm}$ \\
\hline Cem 15.2a & 0-Corante entra $\mathrm{p} / 1 \mathrm{~mm}$ & 0-Corante entra $\mathrm{p} / 1 \mathrm{~mm}$ \\
\hline Cem 15.2b & 0-Corante entra $\mathrm{p} / 1 \mathrm{~mm}$ & 0-Corante entra $\mathrm{p} / 1 \mathrm{~mm}$ \\
\hline Cem.15.3a & 0-Corante entra $\mathrm{p} / 1 \mathrm{~mm}$ & 0-Corante entra $\mathrm{p} / 1 \mathrm{~mm}$ \\
\hline Cem 15.3b & 0-Corante entra $\mathrm{p} / 1 \mathrm{~mm}$ & 0-Corante entra $\mathrm{p} / 1 \mathrm{~mm}$ \\
\hline Cem 15.4a & 0-Corante entra $\mathrm{p} / 1 \mathrm{~mm}$ & 0-Corante entra $\mathrm{p} / 1 \mathrm{~mm}$ \\
\hline Cem 15.4b & 0-Corante entra $\mathrm{p} / 1 \mathrm{~mm}$ & 0-Corante entra $\mathrm{p} / 1 \mathrm{~mm}$ \\
\hline
\end{tabular}

\section{CORPO 16}

\begin{tabular}{|c|c|c|}
\hline & MARGEM GENGIVAL & MARGEM OCLUSAL \\
\hline Cem 16.1a & 0-Corante entra $\mathrm{p} / 1 \mathrm{~mm}$ & 0-Corante entra $\mathrm{p} / 1 \mathrm{~mm}$ \\
\hline Cem 16.1b & 0-Corante entra $\mathrm{p} / 1 \mathrm{~mm}$ & 0-Corante entra $\mathrm{p} / 1 \mathrm{~mm}$ \\
\hline Cem 16.2a & 0-Corante entra $\mathrm{p} / 1 \mathrm{~mm}$ & 0-Corante entra $\mathrm{p} / 1 \mathrm{~mm}$ \\
\hline Cem 16.2b & 0-Corante entra $\mathrm{p} / 1 \mathrm{~mm}$ & 0-Corante entra $\mathrm{p} / 1 \mathrm{~mm}$ \\
\hline Cem.16.3a & 0-Corante entra $\mathrm{p} / 1 \mathrm{~mm}$ & 0-Corante entra $\mathrm{p} / 1 \mathrm{~mm}$ \\
\hline Cem 16.3b & 0-Corante entra $\mathrm{p} / 1 \mathrm{~mm}$ & 0-Corante entra $\mathrm{p} / 1 \mathrm{~mm}$ \\
\hline Cem 16.4a & 0-Corante entra $\mathrm{p} / 1 \mathrm{~mm}$ & 0-Corante entra $\mathrm{p} / 1 \mathrm{~mm}$ \\
\hline Cem 16.4b & 0-Corante entra $\mathrm{p} / 1 \mathrm{~mm}$ & 0-Corante entra $\mathrm{p} / 1 \mathrm{~mm}$ \\
\hline
\end{tabular}


CORPO 17

\begin{tabular}{|c|c|c|}
\hline & MARGEM GENGIVAL & MARGEM OCLUSAL \\
\hline Cem 17.1a & 0-Corante entra $\mathrm{p} / 1 \mathrm{~mm}$ & 0-Corante entra $\mathrm{p} / 1 \mathrm{~mm}$ \\
\hline Cem 17.1b & 0-Corante entra $\mathrm{p} / 1 \mathrm{~mm}$ & 0-Corante entra $\mathrm{p} / 1 \mathrm{~mm}$ \\
\hline Cem 17.2a & 0-Corante entra $\mathrm{p} / 1 \mathrm{~mm}$ & 0-Corante entra $\mathrm{p} / 1 \mathrm{~mm}$ \\
\hline Cem 17.2b & 0-Corante entra $\mathrm{p} / 1 \mathrm{~mm}$ & 0-Corante entra $\mathrm{p} / 1 \mathrm{~mm}$ \\
\hline Cem.17.3a & 0-Corante entra $\mathrm{p} / 1 \mathrm{~mm}$ & 0-Corante entra $\mathrm{p} / 1 \mathrm{~mm}$ \\
\hline Cem 17.3b & 0-Corante entra $\mathrm{p} / 1 \mathrm{~mm}$ & 0-Corante entra $\mathrm{p} / 1 \mathrm{~mm}$ \\
\hline Cem 17.4a & 0-Corante entra $\mathrm{p} / 1 \mathrm{~mm}$ & 0-Corante entra $\mathrm{p} / 1 \mathrm{~mm}$ \\
\hline Cem 17.4b & 0-Corante entra $\mathrm{p} / 1 \mathrm{~mm}$ & 0-Corante entra $\mathrm{p} / 1 \mathrm{~mm}$ \\
\hline
\end{tabular}

\section{CORPO 18}

\begin{tabular}{|c|c|c|}
\hline & MARGEM GENGIVAL & MARGEM OCLUSAL \\
\hline Cem 18.1a & 0,27 & 0 \\
\hline Cem 18.1b & 0- sem restauração & 0- sem restauração \\
\hline Cem 18.2a & 0 & 0 \\
\hline Cem 18.2b & 0 & 0 \\
\hline Cem.18.3a & 1,81 & 0 \\
\hline Cem 18.3b & 0,89 & 0 \\
\hline Cem 18.4a & 0-Pouca restauração & 0-Pouca restauração \\
\hline Cem 18.4b & 0-Pouca restauração & 0-Pouca restauração \\
\hline
\end{tabular}

\section{CORPO 19}

\begin{tabular}{|c|c|c|}
\hline & MARGEM GENGIVAL & MARGEM OCLUSAL \\
\hline Cem 17.1a & 0-Corante entra $\mathrm{p} / 1 \mathrm{~mm}$ & 0-Corante entra $\mathrm{p} / 1 \mathrm{~mm}$ \\
\hline Cem 17.1b & 0-Corante entra $\mathrm{p} / 1 \mathrm{~mm}$ & 0-Corante entra $\mathrm{p} / 1 \mathrm{~mm}$ \\
\hline Cem 17.2a & 0-Corante entra $\mathrm{p} / 1 \mathrm{~mm}$ & 0-Corante entra $\mathrm{p} / 1 \mathrm{~mm}$ \\
\hline Cem 17.2b & 0-Corante entra $\mathrm{p} / 1 \mathrm{~mm}$ & 0-Corante entra $\mathrm{p} / 1 \mathrm{~mm}$ \\
\hline Cem.17.3a & 0-Corante entra $\mathrm{p} / 1 \mathrm{~mm}$ & 0-Corante entra $\mathrm{p} / 1 \mathrm{~mm}$ \\
\hline Cem 17.3b & 0-Corante entra $\mathrm{p} / 1 \mathrm{~mm}$ & 0-Corante entra $\mathrm{p} / 1 \mathrm{~mm}$ \\
\hline Cem 17.4a & 0-Corante entra $\mathrm{p} / 1 \mathrm{~mm}$ & 0-Corante entra $\mathrm{p} / 1 \mathrm{~mm}$ \\
\hline Cem 17.4b & 0-Corante entra $\mathrm{p} / 1 \mathrm{~mm}$ & 0-Corante entra $\mathrm{p} / 1 \mathrm{~mm}$ \\
\hline
\end{tabular}

\section{GRUPO DE 200 CICLOS}

\section{CORPO 1}

\begin{tabular}{|c|c|c|}
\hline & MARGEM GENGIVAL & MARGEM OCLUSAL \\
\hline Duze $1.1 \mathrm{a}$ & 0 & 0 \\
\hline Duze $1.1 \mathrm{~b}$ & 0 & 0 \\
\hline Duze $1.2 \mathrm{a}$ & 0 & 0 \\
\hline Duze $1.2 \mathrm{~b}$ & 0 & 0 \\
\hline Duze $1.3 \mathrm{a}$ & 0 & 0 \\
\hline Duze $1.3 \mathrm{~b}$ & 0 & 0 \\
\hline Duze $1.4 \mathrm{a}$ & 0 & 0 \\
\hline Duze $1.4 \mathrm{~b}$ & 0 & \\
\hline
\end{tabular}


CORPO 2

\begin{tabular}{|c|c|c|}
\hline & MARGEM GENGIVAL & MARGEM OCLUSAL \\
\hline & 0 & 0 \\
\hline Duze $2.1 \mathrm{a}$ & 0 & 0,32 \\
\hline Duze $2.1 \mathrm{~b}$ & 0 & 0,28 \\
\hline Duze $2.2 \mathrm{a}$ & 0 & 0,29 \\
\hline Duze $2.2 \mathrm{~b}$ & 0 & 0,32 \\
\hline Duze $2.3 \mathrm{a}$ & 0 & 0 \\
\hline Duze $2.3 \mathrm{~b}$ & 0 & 0 \\
\hline Duze $2.4 \mathrm{a}$ & 0 & 0 \\
\hline Duze $2.4 \mathrm{~b}$ & 0 & 0 \\
\hline
\end{tabular}

\section{CORPO 3}

\begin{tabular}{|c|c|c|}
\hline & MARGEM GENGIVAL & MARGEM OCLUSAL \\
\hline Duze 3.1a & 0 & 0 \\
\hline Duze 3.1b & 0 & 0 \\
\hline Duze 3.2a & 0 & 0 \\
\hline Duze 3.2b & 0 & 0 \\
\hline Duze 3.3a & 0 & 0 \\
\hline Duze 3.3b & 0 & 0 \\
\hline Duze 3.4a & 0 & 0 \\
\hline Duze 3.4b & 0 & 0 \\
\hline
\end{tabular}

\section{CORPO 4}

\begin{tabular}{|c|c|c|}
\hline & MARGEM GENGIVAL & MARGEM OCLUSAL \\
\hline Duze 4.1a & 0 & 0 \\
\hline Duze 4.1b & 0 & 0 \\
\hline Duze 4.2a & 0 & 0 \\
\hline Duze 4.2b & 0 & 0 \\
\hline Duze 4.3a & 0 & 0 \\
\hline Duze 4.3b & 0 & 0 \\
\hline Duze 4.4a & 0 & 0 \\
\hline Duze 4.4b & 0 & 0 \\
\hline
\end{tabular}

\section{CORPO 5}

\begin{tabular}{|c|c|c|}
\hline & MARGEM GENGIVAL & MARGEM OCLUSAL \\
\hline Duze 5.1a & 0,94 & 0,23 \\
\hline Duze 5.1b & 1,84 & 0 \\
\hline Duze 5.2a & 1,07 & 0 \\
\hline Duze 5.2b & 0,68 & 0 \\
\hline Duze 5.3a & 1,42 & 0 \\
\hline Duze 5.3b & 1,17 & - \\
\hline Duze 5.4a & - & - \\
\hline Duze 5.4b & - & 0 \\
\hline
\end{tabular}


CORPO 6

\begin{tabular}{|c|c|c|}
\hline & MARGEM GENGIVAL & MARGEM OCLUSAL \\
\hline Duze 6.1a & 0 & 0 \\
\hline Duze 6.1b & 0 & 0 \\
\hline Duze 6.2a & 0 & 0 \\
\hline Duze 6.2b & 0 & 0 \\
\hline Duze 6.3a & 0 & 0 \\
\hline Duze 6.3b & 0 & 0 \\
\hline Duze 6.4a & 0 & 0 \\
\hline Duze 6.4b & 0 & 0 \\
\hline
\end{tabular}

\section{CORPO 7}

\begin{tabular}{|c|c|c|}
\hline & MARGEM GENGIVAL & MARGEM OCLUSAL \\
\hline Duze 7.1a & 0 & 0 \\
\hline Duze 7.1b & 0 & 0 \\
\hline Duze 7.2a & 0 & 0 \\
\hline Duze 7.2b & 0 & 0 \\
\hline Duze 7.3a & 0 & 0 \\
\hline Duze 7.3b & 0 & 0 \\
\hline Duze 7.4a & 0 & 0 \\
\hline Duze 7.4b & 0 & 0 \\
\hline
\end{tabular}

\section{CORPO 8}

\begin{tabular}{|c|c|c|}
\hline & MARGEM GENGIVAL & MARGEM OCLUSAL \\
\hline Duze $8.1 \mathrm{a}$ & 0 & 0 \\
\hline Duze $8.1 \mathrm{~b}$ & 0 & 0 \\
\hline Duze $8.2 \mathrm{a}$ & 0 & 0 \\
\hline Duze $8.2 \mathrm{~b}$ & 0 & 0 \\
\hline Duze $8.3 \mathrm{a}$ & 0 & 0 \\
\hline Duze $8.3 \mathrm{~b}$ & 0 & 0 \\
\hline Duze $8.4 \mathrm{a}$ & 0 & 0 \\
\hline Duze $8.4 \mathrm{~b}$ & 0 & 0 \\
\hline
\end{tabular}

CORPO 9

\begin{tabular}{|c|c|c|}
\hline & MARGEM GENGIVAL & MARGEM OCLUSAL \\
\hline Duze 9.1a & 0 & 0 \\
\hline Duze 9.1b & 0 & 0 \\
\hline Duze 9.2a & 0,84 & 0 \\
\hline Duze 9.2b & 0 & 0 \\
\hline Duze 9.3a & 0,72 & 0 \\
\hline Duze 9.3b & 1,01 & - \\
\hline Duze 9.4a & - & - \\
\hline Duze 9.4b & - & 0 \\
\hline
\end{tabular}


CORPO 10

\begin{tabular}{|c|c|c|}
\hline & MARGEM GENGIVAL & MARGEM OCLUSAL \\
\hline Duze 10.1a & 0 & 0 \\
\hline Duze 10.1b & 0 & 0 \\
\hline Duze 10.2a & 0 & 0 \\
\hline Duze 10.2b & 0 & 0 \\
\hline Duze 10.3a & 0 & 0 \\
\hline Duze 10.3b & 0 & 0 \\
\hline Duze 10.4a & 0 & 0 \\
\hline Duze 10.4b & 0 & 0 \\
\hline
\end{tabular}

\section{CORPO 11}

\begin{tabular}{|c|c|c|}
\hline & MARGEM GENGIVAL & MARGEM OCLUSAL \\
\hline Duze 11.1a & 0 & 0 \\
\hline Duze 11.1b & 0 & 0 \\
\hline Duze 11.2a & 0 & 0 \\
\hline Duze 11.2b & 0 & 0 \\
\hline Duze 11.3a & 0 & 0 \\
\hline Duze 11.3b & 0 & 0 \\
\hline Duze 11.4a & 0 & 0 \\
\hline Duze 11.4b & 0 & 0 \\
\hline
\end{tabular}

\section{CORPO 12}

\begin{tabular}{|c|c|c|}
\hline & MARGEM GENGIVAL & MARGEM OCLUSAL \\
\hline Duze 12.1a & 3,06 & 0 \\
\hline Duze 12.1b & 3,70 & 0 \\
\hline Duze 12.2a & 3,37 & 0 \\
\hline Duze 12.2b & 3,08 & 0 \\
\hline Duze 12.3a & 2,98 & 0 \\
\hline Duze 12.3b & 2,11 & 0 \\
\hline Duze 12.4a & 4,06 & 0 \\
\hline Duze 12.4b & 3,74 & 0 \\
\hline
\end{tabular}

\section{CORPO 13}

\begin{tabular}{|c|c|c|}
\hline & MARGEM GENGIVAL & MARGEM OCLUSAL \\
\hline Duze 13.1a & 0 & 0 \\
\hline Duze 13.1b & 0 & 0 \\
\hline Duze 13.2a & 0 & 0 \\
\hline Duze 13.2b & 0 & 0 \\
\hline Duze 13.3a & 0,21 & 0 \\
\hline Duze 13.3b & 0,16 & - \\
\hline Duze 13.4a & - & - \\
\hline Duze 13.4b & - & 0 \\
\hline
\end{tabular}


CORPO 14

\begin{tabular}{|c|c|c|}
\hline & MARGEM GENGIVAL & MARGEM OCLUSAL \\
\hline Duze 14.1a & 0,21 & 0,25 \\
\hline Duze 14.1b & 0-Sem restauração & 0-sem restauração \\
\hline Duze 14.2a & 0,24 & 1,11 \\
\hline Duze 14.2b & 0,13 & 0,28 \\
\hline Duze 14.3a & 0,13 & 0,07 \\
\hline Duze 14.3b & 0,23 & 0,14 \\
\hline Duze 14.4a & - & - \\
\hline Duze 14.4b & - & - \\
\hline
\end{tabular}

\section{CORPO 15}

\begin{tabular}{|c|c|c|}
\hline & MARGEM GENGIVAL & MARGEM OCLUSAL \\
\hline Duze 15.1a & 0,22 & 0 \\
\hline Duze 15.1b & 0,5 & 0,26 \\
\hline Duze 15.2a & 0,17 & 0,23 \\
\hline Duze 15.2b & 0 & 0,28 \\
\hline Duze 15.3a & 0,16 & 0,22 \\
\hline Duze 15.3b & 0,15 & 0,24 \\
\hline Duze 15.4a & - & - \\
\hline Duze 15.4b & - & - \\
\hline
\end{tabular}

\section{CORPO 16}

\begin{tabular}{|c|c|c|}
\hline & MARGEM GENGIVAL & MARGEM OCLUSAL \\
\hline Duze 16.1a & 0,35 & 0,27 \\
\hline Duze 16.1b & 0 & 0,28 \\
\hline Duze 16.2a & 0,39 & 0 \\
\hline Duze 16.2b & 0,34 & 0,22 \\
\hline Duze 16.3a & 0,52 & 0,38 \\
\hline Duze 16.3b & 0,39 & 0,79 \\
\hline Duze 16.4a & - & - \\
\hline Duze 16.4b & - & - \\
\hline
\end{tabular}

\section{CORPO 17}

\begin{tabular}{|c|c|c|}
\hline & MARGEM GENGIVAL & MARGEM OCLUSAL \\
\hline Duze 17.1a & 0,26 & 0,25 \\
\hline Duze 17.1b & 026 & 0,32 \\
\hline Duze 17.2a & 0,21 & 0,28 \\
\hline Duze 17.2b & 0,30 & 0,23 \\
\hline Duze 17.3a & 0,15 & 0,13 \\
\hline Duze 17.3b & 0,17 & 0 \\
\hline Duze 17.4a & - & - \\
\hline Duze 17.4b & - & - \\
\hline
\end{tabular}


CORPO 18

\begin{tabular}{|c|c|c|}
\hline & MARGEM GENGIVAL & MARGEM OCLUSAL \\
\hline Duze 18.1a & 1,77 & 1,02 \\
\hline Duze 18.1b & 1,88 & 1,08 \\
\hline Duze 18.2a & 1,15 & 1,60 \\
\hline Duze 18.2b & 1,09 & 1,15 \\
\hline Duze 18.3a & 1,97 & 0,61 \\
\hline Duze 18.3b & 1,23 & 0,71 \\
\hline Duze 18.4a & - & - \\
\hline Duze 18.4b & - & - \\
\hline
\end{tabular}

\section{CORPO 19}

\begin{tabular}{|c|c|c|}
\hline & MARGEM GENGIVAL & MARGEM OCLUSAL \\
\hline Duze 19.1a & 0,68 & 0 \\
\hline Duze 19.1b & 0,54 & 0,25 \\
\hline Duze 19.2a & 0,54 & 0,25 \\
\hline Duze 19.2b & 0,54 & 0,25 \\
\hline Duze 19.3a & 0,57 & 0,88 \\
\hline Duze 19.3b & 0,56 & 0,88 \\
\hline Duze 19.4a & - & - \\
\hline Duze 19.4b & - & - \\
\hline
\end{tabular}

GRUPO DE 1000 CICLOS

\section{CORPO 1}

\begin{tabular}{|c|c|c|}
\hline & MARGEM GENGIVAL & MARGEM OCLUSAL \\
\hline Mil 1.1a & 0 & 0 \\
\hline Mil 1.1b & 0 & 0 \\
\hline Mil 1.2a & 0 & 0 \\
\hline Mil 1.2b & 0 & 0 \\
\hline Mil 1.3a & 0 & 0 \\
\hline Mil 1.3b & 0 & 0 \\
\hline Mil 1.4a & 0 & 0 \\
\hline Mil 1.4b & 0 & 0 \\
\hline
\end{tabular}

CORPO 2

\begin{tabular}{|c|c|c|}
\hline & MARGEM GENGIVAL & MARGEM OCLUSAL \\
\hline Mil 2.1a & 0 & 0 \\
\hline Mil 2.1b & 0 & 0 \\
\hline Mil 2.2a & 0 & 0 \\
\hline Mil 2.2b & 0 & 0 \\
\hline Mil 2.3a & 0 & 0 \\
\hline Mil 2.3b & 0 & 0 \\
\hline Mil 2.4a & 0 & 0 \\
\hline Mil 2.4b & 0 & 0 \\
\hline
\end{tabular}


CORPO 3

\begin{tabular}{|c|c|c|}
\hline & MARGEM GENGIVAL & MARGEM OCLUSAL \\
\hline Mil 3.1a & 0,57 & 0 \\
\hline Mil 3.1b & 0-Sem restauração & 0 -sem restauração \\
\hline Mil 3.2a & 0,72 & 0 \\
\hline Mil 3.2b & 1,09 & 0 \\
\hline Mil 3.3a & 0,74 & 0 \\
\hline Mil 3.3b & 0,76 & 0 \\
\hline Mil 3.4a & 1,43 & 0 \\
\hline Mil 3.4b & 1,40 & 0 \\
\hline
\end{tabular}

\section{CORPO 4}

\begin{tabular}{|c|c|c|}
\hline & MARGEM GENGIVAL & MARGEM OCLUSAL \\
\hline Mil 4.1a & 0 & 0 \\
\hline Mil 4.1b & 0 & 0 \\
\hline Mil 4.2a & 0 & 0 \\
\hline Mil 4.2b & 0 & 0 \\
\hline Mil 4.3a & 0 & 0 \\
\hline Mil 4.3b & 0 & 0 \\
\hline Mil 4.4a & 0 & 0 \\
\hline Mil 4.4b & 0 & 0 \\
\hline
\end{tabular}

\section{CORPO 5}

\begin{tabular}{|c|c|c|}
\hline & MARGEM GENGIVAL & MARGEM OCLUSAL \\
\hline Mil 5.1a & 0 & 0 \\
\hline Mil 5.1b & 0 & 0 \\
\hline Mil 5.2a & 0 & 0 \\
\hline Mil 5.2b & 0 & 0 \\
\hline Mil 5.3a & 0 & 0 \\
\hline Mil 5.3b & 0 & 0 \\
\hline Mil 5.4a & 0 & 0 \\
\hline Mil 5.4b & 0 & 0 \\
\hline
\end{tabular}

\section{CORPO 6}

\begin{tabular}{|c|c|c|}
\hline & MARGEM GENGIVAL & MARGEM OCLUSAL \\
\hline Mil 6.1a & 0 & 0 \\
\hline Mil 6.1b & 0 & 0 \\
\hline Mil 6.2a & 0 & 0 \\
\hline Mil 6.2b & 0 & 0 \\
\hline Mil 6.3a & 0 & 0 \\
\hline Mil 6.3b & 0 & 0 \\
\hline Mil 6.4a & 0 & 0 \\
\hline Mil 6.4b & 0 & 0 \\
\hline
\end{tabular}


CORPO 7

\begin{tabular}{|c|c|c|}
\hline & MARGEM GENGIVAL & MARGEM OCLUSAL \\
\hline Mil 7.1a & 2,14 & 0 \\
\hline Mil 7.1b & 1,73 & 0 \\
\hline Mil 7.2a & 3,67 & 0 \\
\hline Mil 7.2b & 2,37 & 0 \\
\hline Mil 7.3a & 3,03 & 0 \\
\hline Mil 7.3b & 4,24 & - \\
\hline Mil 7.4a & - & - \\
\hline Mil 7.4b & - & \\
\hline
\end{tabular}

CORPO 8

\begin{tabular}{|c|c|c|}
\hline & MARGEM GENGIVAL & MARGEM OCLUSAL \\
\hline Mil 8.1a & 0 & 0 \\
\hline Mil 8.1b & 0 & 0 \\
\hline Mil 8.2a & 0 & 0 \\
\hline Mil 8.2b & 0 & 0 \\
\hline Mil 8.3a & 0 & 0 \\
\hline Mil 8.3b & 0 & 0 \\
\hline Mil 8.4a & 0 & 0 \\
\hline Mil 8.4b & 0 & 0 \\
\hline
\end{tabular}

\section{CORPO 9}

\begin{tabular}{|c|c|c|}
\hline & MARGEM GENGIVAL & MARGEM OCLUSAL \\
\hline Mil 9.1a & 1,66 & 0 \\
\hline Mil 9.1b & 1,54 & 0 \\
\hline Mil 9.2a & 1,29 & 0 \\
\hline Mil 9.2b & 1,49 & 0 \\
\hline Mil 9.3a & 0,72 & 0 \\
\hline Mil 9.3b & 0,75 & - \\
\hline Mil 9.4a & - & - \\
\hline Mil 9.4b & - & 0 \\
\hline
\end{tabular}

CORPO 10

\begin{tabular}{|c|c|c|}
\hline & MARGEM GENGIVAL & MARGEM OCLUSAL \\
\hline Mil 10.1a & 0 & 0 \\
\hline Mil 10.1b & 0 & 0 \\
\hline Mil 10.2a & 0 & 0 \\
\hline Mil 10.2b & 0 & 0 \\
\hline Mil 10.3a & 0 & 0,26 \\
\hline Mil 10.3b & 0 & 0,33 \\
\hline Mil 10.4a & - & - \\
\hline Mil 10.4b & - & - \\
\hline
\end{tabular}


CORPO 11

\begin{tabular}{|c|c|c|}
\hline & MARGEM GENGIVAL & MARGEM OCLUSAL \\
\hline Mil 11.1a & 0,26 & 0 \\
\hline Mil 11.1b & 0,21 & 0 \\
\hline Mil 11.2a & 0 & 0 \\
\hline Mil 11.2b & 0 & 0 \\
\hline Mil 11.3a & 0,21 & 0 \\
\hline Mil 11.3b & 0,23 & 0 \\
\hline Mil 11.4a & 0,37 & 0 \\
\hline Mil 11.4b & 0,41 & 0 \\
\hline
\end{tabular}

CORPO 12

\begin{tabular}{|c|c|c|}
\hline & MARGEM GENGIVAL & MARGEM OCLUSAL \\
\hline Mil 12.1a & 0 & 0 \\
\hline Mil 12.1b & 0 & 0 \\
\hline Mil 12.2a & 0,23 & 0 \\
\hline Mil 12.2b & 0,15 & - \\
\hline Mil 12.3a & - & - \\
\hline Mil 12.3b & - & - \\
\hline Mil 12.4a & - & - \\
\hline Mil 12.4b & - & \\
\hline
\end{tabular}

\section{CORPO 13}

\begin{tabular}{|c|c|c|}
\hline & MARGEM GENGIVAL & MARGEM OCLUSAL \\
\hline Mil 13.1a & 0 & 1,15 \\
\hline Mil 13.1b & 0 & 0,43 \\
\hline Mil 13.2a & 0 & 0,47 \\
\hline Mil 13.2b & 0 & 0,57 \\
\hline Mil 13.3a & 0 & 3,85 \\
\hline Mil 13.3b & 0 & 2,20 \\
\hline Mil 13.4a & - & - \\
\hline Mil 13.4b & - & - \\
\hline
\end{tabular}

\section{CORPO 14}

\begin{tabular}{|c|c|c|}
\hline & MARGEM GENGIVAL & MARGEM OCLUSAL \\
\hline Mil 14.1a & 0,93 & 1,4 \\
\hline Mil 14.1b & 2,15 & 1,14 \\
\hline Mil 14.2a & 1,98 & 0,26 \\
\hline Mil 14.2b & 1,52 & 0,79 \\
\hline Mil 14.3a & 1,44 & 0,32 \\
\hline Mil 14.3b & 1,59 & 0,38 \\
\hline Mil 14.4a & - & - \\
\hline Mil 14.4b & - & - \\
\hline
\end{tabular}


CORPO 15

\begin{tabular}{|c|c|c|}
\hline & MARGEM GENGIVAL & MARGEM OCLUSAL \\
\hline Mil 15.1a & 0,94 & 0 \\
\hline Mil 15.1b & 1,11 & 0 \\
\hline Mil 15.2a & 0,53 & 0 \\
\hline Mil 15.2b & 0,58 & 0 \\
\hline Mil 15.3a & 0,99 & 0 \\
\hline Mil 15.3b & 0,52 & - \\
\hline Mil 15.4a & - & - \\
\hline Mil 15.4b & - & 0 \\
\hline
\end{tabular}

\section{CORPO 16}

\begin{tabular}{|c|c|c|}
\hline & MARGEM GENGIVAL & MARGEM OCLUSAL \\
\hline Mil 16.1a & 1,09 & 0 \\
\hline Mil 16.1b & 1,16 & 0 \\
\hline Mil 16.2a & 1,05 & 0 \\
\hline Mil 16.2b & 0,78 & 0 \\
\hline Mil 16.3a & 0,59 & 0 \\
\hline Mil 16.3b & 0,72 & - \\
\hline Mil 16.4a & - & - \\
\hline Mil 16.4b & - & 0 \\
\hline
\end{tabular}

\section{CORPO 17}

\begin{tabular}{|c|c|c|}
\hline & MARGEM GENGIVAL & MARGEM OCLUSAL \\
\hline Mil 17.1a & 0 & 0 \\
\hline Mil 17.1b & 0 & 0 \\
\hline Mil 17.2a & 0 & 0 \\
\hline Mil 17.2b & 0 & 0 \\
\hline Mil 17.3a & 0 & 0 \\
\hline Mil 17.3b & 0 & 0 \\
\hline Mil 17.4a & 0 & 0 \\
\hline Mil 17.4b & 0 & 0 \\
\hline
\end{tabular}

\section{CORPO 18}

\begin{tabular}{|c|c|c|}
\hline & MARGEM GENGIVAL & MARGEM OCLUSAL \\
\hline Mil 18.1a & 0-entra pelo $1 \mathrm{~mm}$ & 0 \\
\hline Mil 18.1b & 0-entra pelo $1 \mathrm{~mm}$ & 0,22 \\
\hline Mil 18.2a & 0-entra pelo $1 \mathrm{~mm}$ & 0,55 \\
\hline Mil 18.2b & 0-entra pelo 1mm & 0,17 \\
\hline Mil 18.3a & 0-entra pelo $1 \mathrm{~mm}$ & 0,22 \\
\hline Mil 18.3b & 0-entra pelo $1 \mathrm{~mm}$ & - \\
\hline Mil 18.4a & - & - \\
\hline Mil 18.4b & - & \\
\hline
\end{tabular}


CORPO 19

\begin{tabular}{|c|c|c|}
\hline & MARGEM GENGIVAL & MARGEM OCLUSAL \\
\hline Mil 19.1a & 0 & 0 \\
\hline Mil 19.1b & 0,34 & 0 \\
\hline Mil 19.2a & 0,33 & 0 \\
\hline Mil 19.2b & 0,26 & 0 \\
\hline Mil 19.3a & 0 & 0 \\
\hline Mil 19.3b & 0 & - \\
\hline Mil 19.4a & - & - \\
\hline Mil 19.4b & - & 0 \\
\hline
\end{tabular}

LEITURA DA ÁREA $\left(\mathrm{mm}^{2}\right)$

\section{GRUPO NENHUM CICLO}

\section{CORPO 1}

\begin{tabular}{|c|c|c|}
\hline & MARGEM GENGIVAL & MARGEM OCLUSAL \\
\hline Zero 1.1a & 0 & 0 \\
\hline Zero 1.1b & 0 & 0 \\
\hline Zero 1.2a & 0 & 0 \\
\hline Zero 1.2b & 0 & 0 \\
\hline Zero 1.3a & 0 & 0 \\
\hline Zero 1.3b & 0 & 0 \\
\hline Zero 1.4a & 0 & 0 \\
\hline Zero 1.4b & 0 & 0 \\
\hline
\end{tabular}

\section{CORPO 2}

\begin{tabular}{|c|c|c|}
\hline & MARGEM GENGIVAL & MARGEM OCLUSAL \\
\hline Zero 2.1a & 0 & 0 \\
\hline Zero 2.1b & 0 & 0 \\
\hline Zero 2.2a & 0 & 0 \\
\hline Zero 2.2b & 0 & 0 \\
\hline Zero 2.3a & 0 & 0 \\
\hline Zero 2.3b & 0 & 0 \\
\hline Zero 2.4a & 0 & 0 \\
\hline Zero 2.4b & 0 & 0 \\
\hline
\end{tabular}

\section{CORPO 3}

\begin{tabular}{|c|c|c|}
\hline & MARGEM GENGIVAL & MARGEM OCLUSAL \\
\hline Zero 3.1a & 0 & 0 \\
\hline Zero 3.1b & 0 & 0 \\
\hline Zero 3.2a & 0 & 0 \\
\hline Zero 3.2b & 0 & 0 \\
\hline Zero 3.3a & 0 & 0 \\
\hline Zero 3.3b & 0 & 0 \\
\hline Zero 3.4a & 0 & 0 \\
\hline Zero 3.4b & 0 & 0 \\
\hline
\end{tabular}




\section{CORPO 4}

\begin{tabular}{|c|c|c|}
\hline & MARGEM GENGIVAL & MARGEM OCLUSAL \\
\hline Zero 4.1a & 0 & 0 \\
\hline Zero 4.1b & 0 & 0 \\
\hline Zero 4.2a & 0 & 0 \\
\hline Zero 4.2b & 0 & 0 \\
\hline Zero 4.3a & 0 & 0 \\
\hline Zero 4.3b & 0 & 0 \\
\hline Zero 4.4a & 0 & 0 \\
\hline Zero 4.4b & 0 & 0 \\
\hline
\end{tabular}

\section{CORPO 5}

\begin{tabular}{|c|c|c|}
\hline & MARGEM GENGIVAL & MARGEM OCLUSAL \\
\hline Zero 5.1a & 0 & 0 \\
\hline Zero 5.1b & 0 & 0 \\
\hline Zero 5.2a & 0 & 0 \\
\hline Zero 5.2b & 0 & 0 \\
\hline Zero 5.3a & 0 & 0 \\
\hline Zero 5.3b & 0 & 0 \\
\hline Zero 5.4a & 0 & 0 \\
\hline Zero 5.4b & 0 & 0 \\
\hline
\end{tabular}

\section{CORPO 6}

\begin{tabular}{|c|c|c|}
\hline & MARGEM GENGIVAL & MARGEM OCLUSAL \\
\hline Zero 6.1a & 0 & 0 \\
\hline Zero 6.1b & 0 & 0 \\
\hline Zero 6.2a & 0 & 0 \\
\hline Zero 6.2b & 0 & 0 \\
\hline Zero 6.3a & 0 & 0 \\
\hline Zero 6.3b & 0 & 0 \\
\hline Zero 6.4a & 0 & 0 \\
\hline Zero 6.4b & 0 & 0 \\
\hline
\end{tabular}

\section{CORPO 7}

\begin{tabular}{|c|c|c|}
\hline & MARGEM GENGIVAL & MARGEM OCLUSAL \\
\hline Zero 7.1a & 0 & 0 \\
\hline Zero 7.1b & 0 & 0 \\
\hline Zero 7.2a & 0 & 0 \\
\hline Zero 7.2b & 0 & 0 \\
\hline Zero 7.3a & 0 & 0 \\
\hline Zero 7.3b & 0 & 0 \\
\hline Zero 7.4a & 0 & 0 \\
\hline Zero 7.4b & 0 & 0 \\
\hline
\end{tabular}




\section{CORPO 8}

\begin{tabular}{|c|c|c|}
\hline & MARGEM GENGIVAL & MARGEM OCLUSAL \\
\hline Zero 8.1a & 0 & 0 \\
\hline Zero 8.1b & 0 & 0 \\
\hline Zero 8.2a & 0 & 0 \\
\hline Zero 8.2b & 0 & 0 \\
\hline Zero 8.3a & 0 & 0 \\
\hline Zero 8.3b & 0 & 0 \\
\hline Zero 8.4a & 0 & 0 \\
\hline Zero 8.4b & 0 & 0 \\
\hline
\end{tabular}

\section{CORPO 9}

\begin{tabular}{|c|c|c|}
\hline & MARGEM GENGIVAL & MARGEM OCLUSAL \\
\hline Zero 9.1a & 0 & 0 \\
\hline Zero 9.1b & 0 & 0 \\
\hline Zero 9.2a & 0 & 0 \\
\hline Zero 9.2b & 0 & 0 \\
\hline Zero 9.3a & 0 & 0 \\
\hline Zero 9.3b & 0 & 0 \\
\hline Zero 9.4a & 0 & 0 \\
\hline Zero 9.4b & 0 & 0 \\
\hline
\end{tabular}

\section{CORPO 10}

\begin{tabular}{|c|c|c|}
\hline & MARGEM GENGIVAL & MARGEM OCLUSAL \\
\hline Zero 10.1a & 0-sem restauração & 0-sem restauração \\
\hline Zero 10.1b & 0-sem restauração & 0-sem restauração \\
\hline Zero 10.2a & 0,04 & 0,07 \\
\hline Zero 10.2b & 0,02 & 0,05 \\
\hline Zero 10.3a & 0,05 & 0,06 \\
\hline Zero 10.3b & 0,03 & 0,04 \\
\hline Zero 10.4a & 0 & 0,15 \\
\hline Zero 10.4b & 0 & 0,15 \\
\hline
\end{tabular}

\section{CORPO 11}

\begin{tabular}{|c|c|c|}
\hline & MARGEM GENGIVAL & MARGEM OCLUSAL \\
\hline Zero 11.1a & 0-sem restauração & 0-sem restauração \\
\hline Zero 11.1b & 0-sem restauração & 0-sem restauração \\
\hline Zero 11.2a & 0 & 0,04 \\
\hline Zero 11.2b & 0 & 0,05 \\
\hline Zero 11.3a & 0 & 0,04 \\
\hline Zero 11.3b & 0 & 0,02 \\
\hline Zero 11.4a & 0 & 0,03 \\
\hline Zero 11.4b & 0 & 0,03 \\
\hline
\end{tabular}




\section{CORPO 12}

\begin{tabular}{|c|c|c|}
\hline & MARGEM GENGIVAL & MARGEM OCLUSAL \\
\hline Zero 12.1a & 0,03 & 0 \\
\hline Zero 12.1b & 0,03 & 0,02 \\
\hline Zero 12.2a & 0 & 0 \\
\hline Zero 12.2b & 0,02 & 0 \\
\hline Zero 12.3a & 0,07 & 0 \\
\hline Zero 12.3b & 0,04 & 0-sem restauração \\
\hline Zero 12.4a & 0-Sem restauração & 0-sem restauração \\
\hline Zero 12.4b & 0-sem restauração & \\
\hline
\end{tabular}

\section{CORPO 13}

\begin{tabular}{|c|c|c|}
\hline & MARGEM GENGIVAL & MARGEM OCLUSAL \\
\hline Zero 13.1a & 0-sem restauração & 0-sem restauração \\
\hline Zero 13.1b & 0-sem restauração & 0-sem restauração \\
\hline Zero 13.2a & 0 & 0 \\
\hline Zero 13.2b & 0 & 0 \\
\hline Zero 13.3a & 0 & 0 \\
\hline Zero 13.3b & 0 & 0 \\
\hline Zero 13.4a & 0 & 0 \\
\hline Zero 13.4b & 0 & 0 \\
\hline
\end{tabular}

\section{CORPO 14}

\begin{tabular}{|c|c|c|}
\hline & MARGEM GENGIVAL & MARGEM OCLUSAL \\
\hline Zero 13.1a & 0-sem restauração & 0-sem restauração \\
\hline Zero 13.1b & 0-sem restauração & 0-sem restauração \\
\hline Zero 13.2a & 0 & 0 \\
\hline Zero 13.2b & 0 & 0 \\
\hline Zero 13.3a & 0 & 0,05 \\
\hline Zero 13.3b & 0 & 0,04 \\
\hline Zero 13.4a & 0-sem restauração & 0-sem restauração \\
\hline Zero 13.4b & 0-sem restauração & 0-sem restauração \\
\hline
\end{tabular}

\section{CORPO 15}

\begin{tabular}{|c|c|c|}
\hline & MARGEM GENGIVAL & MARGEM OCLUSAL \\
\hline Zero 15.1a & 0 & 0 \\
\hline Zero 15.1b & 0,01 & 0 \\
\hline Zero 15.2a & 0 & 0 \\
\hline Zero 15.2b & 0 & 0 \\
\hline Zero 15.3a & 0 & 0 \\
\hline Zero 15.3b & 0 & - \\
\hline Zero 15.4a & - & - \\
\hline Zero 15.4b & - & 0 \\
\hline
\end{tabular}




\section{CORPO 16}

\begin{tabular}{|c|c|c|}
\hline & MARGEM GENGIVAL & MARGEM OCLUSAL \\
\hline Zero 16.1a & 0 & 0 \\
\hline Zero 16.1b & 0 & 0 \\
\hline Zero 16.2a & 0,04 & 0 \\
\hline Zero 16.2b & 0 & - \\
\hline Zero 16.3a & - & - \\
\hline Zero 16.3b & - & - \\
\hline Zero 16.4a & - & - \\
\hline Zero 16.4b & - & 0 \\
\hline
\end{tabular}

\section{CORPO 17}

\begin{tabular}{|c|c|c|}
\hline & MARGEM GENGIVAL & MARGEM OCLUSAL \\
\hline Zero 17.1a & 0,07 & 0 \\
\hline Zero 17.1b & 0,02 & 0 \\
\hline Zero 17.2a & 0,03 & 0 \\
\hline Zero 17.2b & 0,03 & 0 \\
\hline Zero 17.3a & 0 & 0 \\
\hline Zero 17.3b & 0 & - \\
\hline Zero 17.4a & - & - \\
\hline Zero 17.4b & - & 0 \\
\hline
\end{tabular}

\section{CORPO 18}

\begin{tabular}{|c|c|c|}
\hline & MARGEM GENGIVAL & MARGEM OCLUSAL \\
\hline Zero 18.1a & 0 & 0 \\
\hline Zero 18.1b & 0,04 & 0 \\
\hline Zero 18.2a & 0 & 0 \\
\hline Zero 18.2b & 0 & 0 \\
\hline Zero 18.3a & 0,12 & 0 \\
\hline Zero 18.3b & 0,18 & - \\
\hline Zero 18.4a & - & - \\
\hline Zero 18.4b & - & 0 \\
\hline
\end{tabular}

\section{CORPO 19}

\begin{tabular}{|c|c|c|}
\hline & MARGEM GENGIVAL & MARGEM OCLUSAL \\
\hline Zero 19.1a & 0-sem restauração & 0-sem restauração \\
\hline Zero 19.1b & 0-sem restauração & 0-sem restauração \\
\hline Zero 19.2a & 0,05 & 0,08 \\
\hline Zero 19.2b & 0,03 & 0,06 \\
\hline Zero 19.3a & 0 & 0 \\
\hline Zero 19.3b & 0 & 0 \\
\hline Zero 19.4a & 0 & 0,13 \\
\hline Zero 19.4b & 0 & 0,02 \\
\hline
\end{tabular}


GRUPO DE 100 CICLOS

\section{CORPO 1}

\begin{tabular}{|c|c|c|}
\hline & MARGEM GENGIVAL & MARGEM OCLUSAL \\
\hline Cem $1.1 \mathrm{a}$ & 0 & 0 \\
\hline Cem $1.1 \mathrm{~b}$ & 0 & 0 \\
\hline Cem $1.2 \mathrm{a}$ & 0,75 & 0 \\
\hline Cem $1.2 \mathrm{~b}$ & 2,42 & 0 \\
\hline Cem $1.3 \mathrm{a}$ & 4,72 & 0 \\
\hline Cem 1.3b & 4,05 & - \\
\hline Cem $1.4 \mathrm{a}$ & - & - \\
\hline Cem $1.4 \mathrm{~b}$ & - & \\
\hline
\end{tabular}

\section{CORPO 2}

\begin{tabular}{|c|c|c|}
\hline & MARGEM GENGIVAL & MARGEM OCLUSAL \\
\hline Cem 2.1a & 3,45 & 0 \\
\hline Cem 2.1b & 0,14 & 0 \\
\hline Cem 2.2a & 0,51 & 0 \\
\hline Cem 2.2b & 0,74 & 0 \\
\hline Cem 2.3a & 2,58 & 0 \\
\hline Cem 2.3b & 0,01 & 0 \\
\hline Cem 2.4a & - & - \\
\hline Cem 2.4b & - & - \\
\hline
\end{tabular}

\section{CORPO 3}

\begin{tabular}{|c|c|c|}
\hline & MARGEM GENGIVAL & MARGEM OCLUSAL \\
\hline Cem 3.1a & 0-sem restauração & 0 -sem restauração \\
\hline Cem 3.1b & 0,11 & 0 \\
\hline Cem 3.2a & 0,10 & 0 \\
\hline Cem 3.2b & 0,14 & 0 \\
\hline Cem 3.3a & 0,08 & 0 \\
\hline Cem 3.3b & 0,08 & 0 \\
\hline Cem 3.4a & 0,02 & 0 \\
\hline Cem 3.4b & 0 & \\
\hline
\end{tabular}

\section{CORPO 4}

\begin{tabular}{|c|c|c|}
\hline & MARGEM GENGIVAL & MARGEM OCLUSAL \\
\hline Cem 4.1a & 0,05 & 0-entrou pelo 1mm \\
\hline Cem 4.1b & 0 & 0-entrou pelo $1 \mathrm{~mm}$ \\
\hline Cem 4.2a & 0 & 0-entrou pelo $1 \mathrm{~mm}$ \\
\hline Cem 4.2b & 0 & 0 -entrou pelo $1 \mathrm{~mm}$ \\
\hline Cem 4.3a & 0 & 0 -entrou pelo $1 \mathrm{~mm}$ \\
\hline Cem 4.3b & 0 & 0-entrou pelo $1 \mathrm{~mm}$ \\
\hline Cem 4.4a & 0,02 & 0-entrou pelo 1mm \\
\hline Cem 4.4b & 0-sem restauração & 0-sem restauração \\
\hline
\end{tabular}




\section{CORPO 5}

\begin{tabular}{|c|c|c|}
\hline & MARGEM GENGIVAL & MARGEM OCLUSAL \\
\hline Cem 5.1a & 0,54 & 0,03 \\
\hline Cem 5.1b & 0,36 & 0 \\
\hline Cem 5.2a & 0,48 & 0 \\
\hline Cem 5.2b & 1,16 & 0 \\
\hline Cem 5.3a & 0,17 & 0,01 \\
\hline Cem 5.3b & 0,07 & 0 -sem restauração \\
\hline Cem 5.4a & 0-sem restauração & 0-sem restauração \\
\hline Cem 5.4b & 0-sem restauração & 0 \\
\hline
\end{tabular}

\section{CORPO 6}

\begin{tabular}{|c|c|c|}
\hline & MARGEM GENGIVAL & MARGEM OCLUSAL \\
\hline Cem 6.1a & 0-sem restauração & 0-sem restauração \\
\hline Cem 6.1b & 0-sem restauração & 0-sem restauração \\
\hline Cem 6.2a & 0,39 & 0 \\
\hline Cem 6.2b & 1,73 & 0 \\
\hline Cem 6.3a & 2,69 & 0 \\
\hline Cem 6.3b & 1,52 & 0 \\
\hline Cem 6.4a & 0-sem restauração & 0-sem restauração \\
\hline Cem 6.4b & 0-sem restauração & 0-sem restauração \\
\hline
\end{tabular}

\section{CORPO 7}

\begin{tabular}{|c|c|c|}
\hline & MARGEM GENGIVAL & MARGEM OCLUSAL \\
\hline Cem 7.1a & 0-entrou pelo $1 \mathrm{~mm}$ & 0-entrou pelo $1 \mathrm{~mm}$ \\
\hline Cem 7.1b & 0-entrou pelo $1 \mathrm{~mm}$ & 0-entrou pelo $1 \mathrm{~mm}$ \\
\hline Cem 7.2a & 0-entrou pelo $1 \mathrm{~mm}$ & 0-entrou pelo $1 \mathrm{~mm}$ \\
\hline Cem 7.2b & 0-entrou pelo $1 \mathrm{~mm}$ & 0-entrou pelo $1 \mathrm{~mm}$ \\
\hline Cem 7.3a & 0-entrou pelo $1 \mathrm{~mm}$ & 0-entrou pelo $1 \mathrm{~mm}$ \\
\hline Cem 7.3b & 0-entrou pelo $1 \mathrm{~mm}$ & 0-entrou pelo $1 \mathrm{~mm}$ \\
\hline Cem 7.4a & 0-entrou pelo $1 \mathrm{~mm}$ & 0-entrou pelo $1 \mathrm{~mm}$ \\
\hline Cem 7.4b & 0-entrou pelo $1 \mathrm{~mm}$ & 0-entrou pelo $1 \mathrm{~mm}$ \\
\hline
\end{tabular}

\section{CORPO 8}

\begin{tabular}{|c|c|c|}
\hline & MARGEM GENGIVAL & MARGEM OCLUSAL \\
\hline Cem 8.1a & 0-entrou pelo $1 \mathrm{~mm}$ & 0-entrou pelo $1 \mathrm{~mm}$ \\
\hline Cem 8.1b & 0-entrou pelo $1 \mathrm{~mm}$ & 0-entrou pelo $1 \mathrm{~mm}$ \\
\hline Cem 8.2a & 0-entrou pelo $1 \mathrm{~mm}$ & 0-entrou pelo $1 \mathrm{~mm}$ \\
\hline Cem $8.2 \mathrm{~b}$ & 0-entrou pelo $1 \mathrm{~mm}$ & 0-entrou pelo $1 \mathrm{~mm}$ \\
\hline Cem 8.3a & 0-entrou pelo $1 \mathrm{~mm}$ & 0-entrou pelo $1 \mathrm{~mm}$ \\
\hline Cem 8.3b & 0-entrou pelo $1 \mathrm{~mm}$ & 0-entrou pelo $1 \mathrm{~mm}$ \\
\hline Cem $8.4 \mathrm{a}$ & 0-entrou pelo $1 \mathrm{~mm}$ & 0-entrou pelo $1 \mathrm{~mm}$ \\
\hline Cem $8.4 \mathrm{~b}$ & 0-entrou pelo $1 \mathrm{~mm}$ & 0-entrou pelo $1 \mathrm{~mm}$ \\
\hline
\end{tabular}




\section{CORPO 9}

\begin{tabular}{|c|c|c|}
\hline & MARGEM GENGIVAL & MARGEM OCLUSAL \\
\hline Cem 9.1a & 0 & 0 \\
\hline Cem 9.1b & 0 & 0 \\
\hline Cem 9.2a & 0 & 0 \\
\hline Cem 9.2b & 0,04 & 0 \\
\hline Cem 9.3a & 0,03 & 0 \\
\hline Cem 9.3b & 0,05 & - \\
\hline Cem 9.4a & - & - \\
\hline Cem 9.4b & - & \\
\hline
\end{tabular}

\section{CORPO 10}

\begin{tabular}{|c|c|c|}
\hline & MARGEM GENGIVAL & MARGEM OCLUSAL \\
\hline Cem 10.1a & 0-entrou pelo $1 \mathrm{~mm}$ & 0-entrou pelo $1 \mathrm{~mm}$ \\
\hline Cem 10.1b & 0-entrou pelo $1 \mathrm{~mm}$ & 0-entrou pelo $1 \mathrm{~mm}$ \\
\hline Cem 10.2a & 0-entrou pelo $1 \mathrm{~mm}$ & 0-entrou pelo $1 \mathrm{~mm}$ \\
\hline Cem 10.2b & 0-entrou pelo $1 \mathrm{~mm}$ & 0-entrou pelo $1 \mathrm{~mm}$ \\
\hline Cem 10.3a & 0-entrou pelo $1 \mathrm{~mm}$ & 0-entrou pelo $1 \mathrm{~mm}$ \\
\hline Cem 10.3b & 0-entrou pelo $1 \mathrm{~mm}$ & 0-entrou pelo $1 \mathrm{~mm}$ \\
\hline Cem 10.4a & 0-entrou pelo $1 \mathrm{~mm}$ & 0-entrou pelo $1 \mathrm{~mm}$ \\
\hline Cem 10.4b & 0-entrou pelo $1 \mathrm{~mm}$ & 0-entrou pelo $1 \mathrm{~mm}$ \\
\hline
\end{tabular}

\section{CORPO 11}

\begin{tabular}{|c|c|c|}
\hline & MARGEM GENGIVAL & MARGEM OCLUSAL \\
\hline Cem 11.1a & 0-entrou pelo $1 \mathrm{~mm}$ & 0-entrou pelo $1 \mathrm{~mm}$ \\
\hline Cem 11.1b & 0-entrou pelo $1 \mathrm{~mm}$ & 0-entrou pelo $1 \mathrm{~mm}$ \\
\hline Cem 11.2a & 0-entrou pelo $1 \mathrm{~mm}$ & 0-entrou pelo $1 \mathrm{~mm}$ \\
\hline Cem 11.2b & 0-entrou pelo $1 \mathrm{~mm}$ & 0-entrou pelo $1 \mathrm{~mm}$ \\
\hline Cem 11.3a & 0-entrou pelo $1 \mathrm{~mm}$ & 0-entrou pelo $1 \mathrm{~mm}$ \\
\hline Cem 11.3b & 0-entrou pelo $1 \mathrm{~mm}$ & 0-entrou pelo $1 \mathrm{~mm}$ \\
\hline Cem 11.4a & 0-entrou pelo $1 \mathrm{~mm}$ & 0-entrou pelo $1 \mathrm{~mm}$ \\
\hline Cem 11.4b & 0-entrou pelo $1 \mathrm{~mm}$ & 0-entrou pelo $1 \mathrm{~mm}$ \\
\hline
\end{tabular}

\section{CORPO 12}

\begin{tabular}{|c|c|c|}
\hline & MARGEM GENGIVAL & MARGEM OCLUSAL \\
\hline Cem 12.1a & 0-entrou pelo $1 \mathrm{~mm}$ & 0-entrou pelo 1mm \\
\hline Cem 12.1b & 0-entrou pelo $1 \mathrm{~mm}$ & 0-entrou pelo $1 \mathrm{~mm}$ \\
\hline Cem 12.2a & 0-entrou pelo $1 \mathrm{~mm}$ & 0-entrou pelo $1 \mathrm{~mm}$ \\
\hline Cem 12.2b & 0-entrou pelo $1 \mathrm{~mm}$ & 0-entrou pelo $1 \mathrm{~mm}$ \\
\hline Cem 12.3a & 0-entrou pelo $1 \mathrm{~mm}$ & 0-entrou pelo $1 \mathrm{~mm}$ \\
\hline Cem 12.3b & 0-entrou pelo $1 \mathrm{~mm}$ & 0-entrou pelo $1 \mathrm{~mm}$ \\
\hline Cem 12.4a & 0-entrou pelo $1 \mathrm{~mm}$ & 0-entrou pelo $1 \mathrm{~mm}$ \\
\hline Cem 12.4b & 0-entrou pelo $1 \mathrm{~mm}$ & 0-entrou pelo $1 \mathrm{~mm}$ \\
\hline
\end{tabular}




\section{CORPO 13}

\begin{tabular}{|c|c|c|}
\hline & MARGEM GENGIVAL & MARGEM OCLUSAL \\
\hline Cem 13.1a & 0-entrou pelo $1 \mathrm{~mm}$ & 0-entrou pelo $1 \mathrm{~mm}$ \\
\hline Cem 13.1b & 0-entrou pelo $1 \mathrm{~mm}$ & 0-entrou pelo $1 \mathrm{~mm}$ \\
\hline Cem 13.2a & 0-entrou pelo $1 \mathrm{~mm}$ & 0-entrou pelo $1 \mathrm{~mm}$ \\
\hline Cem 13.2b & 0-entrou pelo $1 \mathrm{~mm}$ & 0-entrou pelo $1 \mathrm{~mm}$ \\
\hline Cem 13.3a & 0-entrou pelo $1 \mathrm{~mm}$ & 0-entrou pelo $1 \mathrm{~mm}$ \\
\hline Cem 13.3b & 0-entrou pelo $1 \mathrm{~mm}$ & 0-entrou pelo $1 \mathrm{~mm}$ \\
\hline Cem 13.4a & 0-entrou pelo $1 \mathrm{~mm}$ & 0-entrou pelo $1 \mathrm{~mm}$ \\
\hline Cem 13.4b & 0-entrou pelo $1 \mathrm{~mm}$ & 0-entrou pelo $1 \mathrm{~mm}$ \\
\hline
\end{tabular}

\section{CORPO 14}

\begin{tabular}{|c|c|c|}
\hline & MARGEM GENGIVAL & MARGEM OCLUSAL \\
\hline Cem 14.1a & 1,65 & 0 \\
\hline Cem 14.1b & 2,32 & 0 \\
\hline Cem 14.2a & 1,58 & 0 \\
\hline Cem 14.2b & 0,32 & 0 \\
\hline Cem 14.3a & 0,55 & 0 \\
\hline Cem 14.3b & 0,45 & - \\
\hline Cem 14.4a & - & - \\
\hline Cem 14.4b & - & \\
\hline
\end{tabular}

\section{CORPO 15}

\begin{tabular}{|c|c|c|}
\hline & MARGEM GENGIVAL & MARGEM OCLUSAL \\
\hline Cem 15.1a & 0-entrou pelo $1 \mathrm{~mm}$ & 0-entrou pelo $1 \mathrm{~mm}$ \\
\hline Cem 15.1b & 0-entrou pelo $1 \mathrm{~mm}$ & 0-entrou pelo $1 \mathrm{~mm}$ \\
\hline Cem 15.2a & 0-entrou pelo $1 \mathrm{~mm}$ & 0-entrou pelo $1 \mathrm{~mm}$ \\
\hline Cem 15.2b & 0-entrou pelo $1 \mathrm{~mm}$ & 0-entrou pelo $1 \mathrm{~mm}$ \\
\hline Cem 15.3a & 0-entrou pelo $1 \mathrm{~mm}$ & 0-entrou pelo $1 \mathrm{~mm}$ \\
\hline Cem 15.3b & 0-entrou pelo $1 \mathrm{~mm}$ & 0-entrou pelo $1 \mathrm{~mm}$ \\
\hline Cem 15.4a & 0-entrou pelo $1 \mathrm{~mm}$ & 0-entrou pelo $1 \mathrm{~mm}$ \\
\hline Cem 15.4b & 0-entrou pelo $1 \mathrm{~mm}$ & 0-entrou pelo $1 \mathrm{~mm}$ \\
\hline
\end{tabular}

\section{CORPO 16}

\begin{tabular}{|c|c|c|}
\hline & MARGEM GENGIVAL & MARGEM OCLUSAL \\
\hline Cem 16.1a & 0-entrou pelo $1 \mathrm{~mm}$ & 0-entrou pelo $1 \mathrm{~mm}$ \\
\hline Cem 16.1b & 0-entrou pelo $1 \mathrm{~mm}$ & 0-entrou pelo $1 \mathrm{~mm}$ \\
\hline Cem 16.2a & 0-entrou pelo $1 \mathrm{~mm}$ & 0-entrou pelo $1 \mathrm{~mm}$ \\
\hline Cem 16.2b & 0-entrou pelo $1 \mathrm{~mm}$ & 0-entrou pelo $1 \mathrm{~mm}$ \\
\hline Cem 16.3a & 0-entrou pelo $1 \mathrm{~mm}$ & 0-entrou pelo $1 \mathrm{~mm}$ \\
\hline Cem 16.3b & 0-entrou pelo $1 \mathrm{~mm}$ & 0-entrou pelo $1 \mathrm{~mm}$ \\
\hline Cem 16.4a & 0-entrou pelo $1 \mathrm{~mm}$ & 0-entrou pelo $1 \mathrm{~mm}$ \\
\hline Cem 16.4b & 0-entrou pelo $1 \mathrm{~mm}$ & 0-entrou pelo $1 \mathrm{~mm}$ \\
\hline
\end{tabular}




\section{CORPO 17}

\begin{tabular}{|c|c|c|}
\hline & MARGEM GENGIVAL & MARGEM OCLUSAL \\
\hline Cem 17.1a & 0-entrou pelo $1 \mathrm{~mm}$ & 0-entrou pelo $1 \mathrm{~mm}$ \\
\hline Cem 17.1b & 0-entrou pelo $1 \mathrm{~mm}$ & 0-entrou pelo $1 \mathrm{~mm}$ \\
\hline Cem 17.2a & 0-entrou pelo $1 \mathrm{~mm}$ & 0-entrou pelo $1 \mathrm{~mm}$ \\
\hline Cem 17.2b & 0-entrou pelo $1 \mathrm{~mm}$ & 0-entrou pelo $1 \mathrm{~mm}$ \\
\hline Cem 17.3a & 0-entrou pelo $1 \mathrm{~mm}$ & 0-entrou pelo $1 \mathrm{~mm}$ \\
\hline Cem 17.3b & 0-entrou pelo $1 \mathrm{~mm}$ & 0-entrou pelo $1 \mathrm{~mm}$ \\
\hline Cem 17.4a & 0-entrou pelo $1 \mathrm{~mm}$ & 0-entrou pelo $1 \mathrm{~mm}$ \\
\hline Cem 17.4b & 0-entrou pelo $1 \mathrm{~mm}$ & 0-entrou pelo $1 \mathrm{~mm}$ \\
\hline
\end{tabular}

\section{CORPO 18}

\begin{tabular}{|c|c|c|}
\hline & MARGEM GENGIVAL & MARGEM OCLUSAL \\
\hline Cem 18.1a & 0,02 & 0 \\
\hline Cem 18.1b & 0-sem restauração & 0- sem restauração \\
\hline Cem 18.2a & 0 & 0 \\
\hline Cem 18.2b & 0 & 0 \\
\hline Cem 18.3a & 0,08 & 0 \\
\hline Cem 18.3b & 0,07 & 0 \\
\hline Cem 18.4a & 0 & 0 \\
\hline Cem 18.4b & 0 & 0 \\
\hline
\end{tabular}

\section{CORPO 19}

\begin{tabular}{|c|c|c|}
\hline & MARGEM GENGIVAL & MARGEM OCLUSAL \\
\hline Cem 19.1a & 0-entrou pelo $1 \mathrm{~mm}$ & 0-entrou pelo $1 \mathrm{~mm}$ \\
\hline Cem 19.1b & 0-entrou pelo $1 \mathrm{~mm}$ & 0-entrou pelo $1 \mathrm{~mm}$ \\
\hline Cem 19.2a & 0-entrou pelo $1 \mathrm{~mm}$ & 0-entrou pelo $1 \mathrm{~mm}$ \\
\hline Cem 19.2b & 0-entrou pelo $1 \mathrm{~mm}$ & 0-entrou pelo $1 \mathrm{~mm}$ \\
\hline Cem 19.3a & 0-entrou pelo $1 \mathrm{~mm}$ & 0-entrou pelo $1 \mathrm{~mm}$ \\
\hline Cem 19.3b & 0-entrou pelo $1 \mathrm{~mm}$ & 0-entrou pelo $1 \mathrm{~mm}$ \\
\hline Cem 19.4a & 0-entrou pelo $1 \mathrm{~mm}$ & 0-entrou pelo $1 \mathrm{~mm}$ \\
\hline Cem 19.4b & 0-entrou pelo $1 \mathrm{~mm}$ & 0-entrou pelo $1 \mathrm{~mm}$ \\
\hline
\end{tabular}

GRUPO DE 200 CICLOS

\section{CORPO 1}

\begin{tabular}{|c|c|c|}
\hline & MARGEM GENGIVAL & MARGEM OCLUSAL \\
\hline Duze 1.1a & 0 & 0 \\
\hline Duze 1.1b & 0 & 0 \\
\hline Duze 1.2a & 0 & 0 \\
\hline Duze 1.2b & 0 & 0 \\
\hline Duze 1.3a & 0 & 0 \\
\hline Duze 1.3b & 0 & 0 \\
\hline Duze 1.4a & 0 & 0 \\
\hline Duze 1.4b & 0 & 0 \\
\hline
\end{tabular}


CORPO 2

\begin{tabular}{|c|c|c|}
\hline & MARGEM GENGIVAL & MARGEM OCLUSAL \\
\hline Duze 2.1a & 0 & 0 \\
\hline Duze 2.1b & 0 & 0 \\
\hline Duze 2.2a & 0 & 0 \\
\hline Duze 2.2b & 0 & 0,06 \\
\hline Duze 2.3a & 0 & 0,04 \\
\hline Duze 2.3b & 0 & 0,04 \\
\hline Duze 2.4a & 0 & 0,09 \\
\hline Duze 2.4b & 0 & 0 \\
\hline
\end{tabular}

\section{CORPO 3}

\begin{tabular}{|c|c|c|}
\hline & MARGEM GENGIVAL & MARGEM OCLUSAL \\
\hline Duze 3.1a & 0 & 0 \\
\hline Duze 3.1b & 0 & 0 \\
\hline Duze 3.2a & 0 & 0 \\
\hline Duze 3.2b & 0 & 0 \\
\hline Duze 3.3a & 0 & 0 \\
\hline Duze 3.3b & 0 & 0 \\
\hline Duze 3.4a & 0 & 0 \\
\hline Duze 3.4b & 0 & 0 \\
\hline
\end{tabular}

\section{CORPO 4}

\begin{tabular}{|c|c|l|}
\hline & MARGEM GENGIVAL & MARGEM OCLUSAL \\
\hline Duze 1.1a & 0-Corante entra $\mathrm{p} / 1 \mathrm{~mm}$ & 0-Corante entra $\mathrm{p} / 1 \mathrm{~mm}$ \\
\hline Duze $1.1 \mathrm{~b}$ & 0-Corante entra $\mathrm{p} / 1 \mathrm{~mm}$ & 0-Corante entra $\mathrm{p} / 1 \mathrm{~mm}$ \\
\hline Duze 1.2a & 0-Corante entra $\mathrm{p} / 1 \mathrm{~mm}$ & 0-Corante entra $\mathrm{p} / 1 \mathrm{~mm}$ \\
\hline Duze 1.2b & 0-Corante entra $\mathrm{p} / 1 \mathrm{~mm}$ & 0-Corante entra $\mathrm{p} / 1 \mathrm{~mm}$ \\
\hline Duze.1.3a & 0-Corante entra $\mathrm{p} / 1 \mathrm{~mm}$ & 0-Corante entra $\mathrm{p} / 1 \mathrm{~mm}$ \\
\hline Duze 1.3b & 0-Corante entra $\mathrm{p} / 1 \mathrm{~mm}$ & 0-Corante entra $\mathrm{p} / 1 \mathrm{~mm}$ \\
\hline Duze 1.4a & 0-Corante entra $\mathrm{p} / 1 \mathrm{~mm}$ & 0-Corante entra $\mathrm{p} / 1 \mathrm{~mm}$ \\
\hline Duze $1.4 \mathrm{~b}$ & 0-Corante entra $\mathrm{p} / 1 \mathrm{~mm}$ & 0-Corante entra $\mathrm{p} / 1 \mathrm{~mm}$ \\
\hline
\end{tabular}

\section{CORPO 5}

\begin{tabular}{|c|c|c|}
\hline & MARGEM GENGIVAL & MARGEM OCLUSAL \\
\hline Duze 5.1a & 0,08 & 0,02 \\
\hline Duze 5.1b & 0,11 & 0 \\
\hline Duze 5.2a & 0,15 & 0 \\
\hline Duze 5.2b & 0,05 & 0 \\
\hline Duze 5.3a & 0,21 & 0 \\
\hline Duze 5.3b & 0,10 & - \\
\hline Duze 5.4a & - & - \\
\hline Duze 5.4b & - & 0 \\
\hline
\end{tabular}




\section{CORPO 6}

\begin{tabular}{|c|c|c|}
\hline & MARGEM GENGIVAL & MARGEM OCLUSAL \\
\hline Duze 6.1a & 0 & 0 \\
\hline Duze 6.1b & 0 & 0 \\
\hline Duze 6.2a & 0 & 0 \\
\hline Duze 6.2b & 0 & 0 \\
\hline Duze 6.3a & 0 & 0 \\
\hline Duze 6.3b & 0 & 0 \\
\hline Duze 6.4a & 0 & 0 \\
\hline Duze 6.4b & 0 & 0 \\
\hline
\end{tabular}

\section{CORPO 7}

\begin{tabular}{|c|c|c|}
\hline & MARGEM GENGIVAL & MARGEM OCLUSAL \\
\hline Duze 7.1a & 0 & 0 \\
\hline Duze 7.1b & 0 & 0 \\
\hline Duze 7.2a & 0 & 0 \\
\hline Duze 7.2b & 0 & 0 \\
\hline Duze 7.3a & 0 & 0 \\
\hline Duze 7.3b & 0 & 0 \\
\hline Duze 7.4a & 0 & 0 \\
\hline Duze 7.4b & 0 & 0 \\
\hline
\end{tabular}

\section{CORPO 8}

\begin{tabular}{|c|c|c|}
\hline & MARGEM GENGIVAL & MARGEM OCLUSAL \\
\hline Duze 8.1a & 0 & 0 \\
\hline Duze 8.1b & 0 & 0 \\
\hline Duze 8.2a & 0 & 0 \\
\hline Duze 8.2b & 0 & 0 \\
\hline Duze 8.3a & 0 & 0 \\
\hline Duze 8.3b & 0 & 0 \\
\hline Duze 8.4a & 0 & 0 \\
\hline Duze $8.4 \mathrm{~b}$ & 0 & 0 \\
\hline
\end{tabular}

\section{CORPO 9}

\begin{tabular}{|c|c|c|}
\hline & MARGEM GENGIVAL & MARGEM OCLUSAL \\
\hline Duze 9.1a & 0 & 0 \\
\hline Duze 9.1b & 0 & 0 \\
\hline Duze 9.2a & 0,05 & 0 \\
\hline Duze 9.2b & 0 & 0 \\
\hline Duze 9.3a & 0,08 & 0 \\
\hline Duze 9.3b & 0,13 & - \\
\hline Duze 9.4a & - & - \\
\hline Duze 9.4b & - & 0 \\
\hline
\end{tabular}




\section{CORPO 10}

\begin{tabular}{|c|c|c|}
\hline & MARGEM GENGIVAL & MARGEM OCLUSAL \\
\hline Duze 10.1a & 0 & 0 \\
\hline Duze 10.1b & 0 & 0 \\
\hline Duze 10.2a & 0 & 0 \\
\hline Duze 10.2b & 0 & 0 \\
\hline Duze 10.3a & 0 & 0 \\
\hline Duze 10.3b & 0 & 0 \\
\hline Duze 10.4a & 0 & 0 \\
\hline Duze 10.4b & 0 & 0 \\
\hline
\end{tabular}

\section{CORPO 11}

\begin{tabular}{|c|c|c|}
\hline & MARGEM GENGIVAL & MARGEM OCLUSAL \\
\hline Duze $11.1 \mathrm{a}$ & 0 & 0 \\
\hline Duze $11.1 \mathrm{~b}$ & 0 & 0 \\
\hline Duze $11.2 \mathrm{a}$ & 0 & 0 \\
\hline Duze $11.2 \mathrm{~b}$ & 0 & 0 \\
\hline Duze $113 \mathrm{a}$ & 0 & 0 \\
\hline Duze $11.3 \mathrm{~b}$ & 0 & 0 \\
\hline Duze $11.4 \mathrm{a}$ & 0 & 0 \\
\hline Duze $11.4 \mathrm{~b}$ & 0 & 0 \\
\hline
\end{tabular}

\section{CORPO 12}

\begin{tabular}{|c|c|c|}
\hline & MARGEM GENGIVAL & MARGEM OCLUSAL \\
\hline & 0,70 & 0 \\
\hline Duze $12.1 \mathrm{a}$ & 0,85 & 0 \\
\hline Duze $12.1 \mathrm{~b}$ & 3,29 & 0 \\
\hline Duze $12.2 \mathrm{a}$ & 0,98 & 0 \\
\hline Duze $12.2 \mathrm{~b}$ & 0,82 & 0 \\
\hline Duze $12.3 \mathrm{a}$ & 0,42 & 0 \\
\hline Duze $12.3 \mathrm{~b}$ & 2,08 & 0 \\
\hline Duze $12.4 \mathrm{a}$ & 4,17 & \\
\hline Duze $12.4 \mathrm{~b}$ & &
\end{tabular}

\section{CORPO 13}

\begin{tabular}{|c|c|c|}
\hline & MARGEM GENGIVAL & MARGEM OCLUSAL \\
\hline Duze 13.1a & 0 & 0 \\
\hline Duze 13.1b & 0 & 0 \\
\hline Duze 13.2a & 0 & 0 \\
\hline Duze 13.2b & 0 & 0 \\
\hline Duze 13.3a & 0,06 & 0 \\
\hline Duze 13.3b & 0,03 & - \\
\hline Duze 13.4a & - & - \\
\hline Duze 13.4b & - & 0 \\
\hline
\end{tabular}




\section{CORPO 14}

\begin{tabular}{|c|c|c|}
\hline & MARGEM GENGIVAL & MARGEM OCLUSAL \\
\hline Duze 14.1a & 0,02 & 0,05 \\
\hline Duze 14.1b & 0 & 0 \\
\hline Duze 14.2a & 0,04 & 0,14 \\
\hline Duze 14.2b & 0,03 & 0,08 \\
\hline Duze 14.3a & 0,02 & 0,02 \\
\hline Duze 14.3b & 0,03 & 0,02 \\
\hline Duze 14.4a & - & - \\
\hline Duze 14.4b & - & - \\
\hline
\end{tabular}

\section{CORPO 15}

\begin{tabular}{|c|c|c|}
\hline & MARGEM GENGIVAL & MARGEM OCLUSAL \\
\hline Duze 15.1a & 0,03 & 0 \\
\hline Duze 15.1b & 0,07 & 0,03 \\
\hline Duze 15.2a & 0,02 & 0,03 \\
\hline Duze 15.2b & 0 & 0,02 \\
\hline Duze 15.3a & 0,01 & 0,03 \\
\hline Duze 15.3b & 0,02 & 0,03 \\
\hline Duze 15.4a & - & - \\
\hline Duze 15.4b & - & - \\
\hline
\end{tabular}

\section{CORPO 16}

\begin{tabular}{|c|c|c|}
\hline & MARGEM GENGIVAL & MARGEM OCLUSAL \\
\hline Duze 16.1a & 0,05 & 0,06 \\
\hline Duze 16.1b & 0 & 0,02 \\
\hline Duze 16.2a & 0,05 & 0 \\
\hline Duze 16.2b & 0,06 & 0,04 \\
\hline Duze 16.3a & 0,09 & 0,10 \\
\hline Duze 16.3b & 0,05 & 0,11 \\
\hline Duze 16.4a & - & - \\
\hline Duze 16.4b & - & - \\
\hline
\end{tabular}

\section{CORPO 17}

\begin{tabular}{|c|c|c|}
\hline & MARGEM GENGIVAL & MARGEM OCLUSAL \\
\hline Duze 17.1a & 0,03 & 0,02 \\
\hline Duze 17.1b & 0,02 & 0,07 \\
\hline Duze 17.2a & 0,05 & 0,04 \\
\hline Duze 17.2b & 0,04 & 0,04 \\
\hline Duze 17.3a & 0,04 & 0,03 \\
\hline Duze 17.3b & 0,02 & 0 \\
\hline Duze 17.4a & - & - \\
\hline Duze 17.4b & - & - \\
\hline
\end{tabular}




\section{CORPO 18}

\begin{tabular}{|c|c|c|}
\hline & MARGEM GENGIVAL & MARGEM OCLUSAL \\
\hline Duze $18.1 \mathrm{a}$ & 0,41 & 0,18 \\
\hline Duze $18.1 \mathrm{~b}$ & 0,85 & 0,21 \\
\hline Duze $18.2 \mathrm{a}$ & 0,36 & 0,21 \\
\hline Duze $18.2 \mathrm{~b}$ & 0,28 & 0,09 \\
\hline Duze18.3a & 1,48 & 0,12 \\
\hline Duze $18.3 \mathrm{~b}$ & 1,37 & 0,10 \\
\hline Duze $18.4 \mathrm{a}$ & - & - \\
\hline Duze $18.4 \mathrm{~b}$ & - & - \\
\hline
\end{tabular}

\section{CORPO 19}

\begin{tabular}{|c|c|c|}
\hline & MARGEM GENGIVAL & MARGEM OCLUSAL \\
\hline Duze 19.1a & 0,09 & 0 \\
\hline Duze 19.1b & 0,09 & 0 \\
\hline Duze 19.2a & 0,08 & 0,04 \\
\hline Duze 19.2b & 0,08 & 0,04 \\
\hline Duze 19.3a & 0,07 & 0,10 \\
\hline Duze 19.3b & 0,07 & 0,10 \\
\hline Duze 19.4a & - & - \\
\hline Duze 19.4b & - & - \\
\hline
\end{tabular}

\section{GRUPO DE 1000 CICLOS}

\section{CORPO 1}

\begin{tabular}{|c|c|c|}
\hline & MARGEM GENGIVAL & MARGEM OCLUSAL \\
\hline Mil 1.1a & 0 & 0 \\
\hline Mil 1.1b & 0 & 0 \\
\hline Mil 1.2a & 0 & 0 \\
\hline Mil 1.2b & 0 & 0 \\
\hline Mil 1.3a & 0 & 0 \\
\hline Mil 1.3b & 0 & 0 \\
\hline Mil 1.4a & 0 & 0 \\
\hline Mil 1.4b & 0 & 0 \\
\hline
\end{tabular}

CORPO 2

\begin{tabular}{|c|c|c|}
\hline & MARGEM GENGIVAL & MARGEM OCLUSAL \\
\hline Mil 2.1a & 0 & 0 \\
\hline Mil 2.1b & 0 & 0 \\
\hline Mil 2.2a & 0 & 0 \\
\hline Mil 2.2b & 0 & 0 \\
\hline Mil 2.3a & 0 & 0 \\
\hline Mil 2.3b & 0 & 0 \\
\hline Mil 2.4a & 0 & 0 \\
\hline Mil 2.4b & 0 & 0 \\
\hline
\end{tabular}


CORPO 3

\begin{tabular}{|c|c|c|}
\hline & MARGEM GENGIVAL & MARGEM OCLUSAL \\
\hline Mil 3.1a & 0,08 & 0 \\
\hline Mil 3.1b & 0- sem restauração & 0-sem restauração \\
\hline Mil 3.2a & 0,13 & 0 \\
\hline Mil 3.2b & 0,16 & 0 \\
\hline Mil 3.3a & 0,10 & 0 \\
\hline Mil 3.3b & 0,07 & 0 \\
\hline Mil 3.4a & 0,28 & 0 \\
\hline Mil 3.4b & 0,30 & 0 \\
\hline
\end{tabular}

\section{CORPO 4}

\begin{tabular}{|c|c|c|}
\hline & MARGEM GENGIVAL & MARGEM OCLUSAL \\
\hline Mil 4.1a & 0 & 0 \\
\hline Mil 4.1b & 0 & 0 \\
\hline Mil 4.2a & 0 & 0 \\
\hline Mil 4.2b & 0 & 0 \\
\hline Mil 4.3a & 0 & 0 \\
\hline Mil 4.3b & 0 & 0 \\
\hline Mil 4.4a & 0 & 0 \\
\hline Mil 4.4b & 0 & 0 \\
\hline
\end{tabular}

\section{CORPO 5}

\begin{tabular}{|c|c|c|}
\hline & MARGEM GENGIVAL & MARGEM OCLUSAL \\
\hline Mil 5.1a & 0 & 0 \\
\hline Mil 5.1b & 0 & 0 \\
\hline Mil 5.2a & 0 & 0 \\
\hline Mil 5.2b & 0 & 0 \\
\hline Mil 5.3a & 0 & 0 \\
\hline Mil 5.3b & 0 & 0 \\
\hline Mil 5.4a & 0 & 0 \\
\hline Mil 5.4b & 0 & 0 \\
\hline
\end{tabular}

\section{CORPO 6}

\begin{tabular}{|c|c|c|}
\hline & MARGEM GENGIVAL & MARGEM OCLUSAL \\
\hline Mil 6.1a & 0 & 0 \\
\hline Mil 6.1b & 0 & 0 \\
\hline Mil 6.2a & 0 & 0 \\
\hline Mil 6.2b & 0 & 0 \\
\hline Mil 6.3a & 0 & 0 \\
\hline Mil 6.3b & 0 & 0 \\
\hline Mil 6.4a & 0 & 0 \\
\hline Mil 6.4b & 0 & \\
\hline
\end{tabular}


CORPO 7

\begin{tabular}{|c|c|c|}
\hline & MARGEM GENGIVAL & MARGEM OCLUSAL \\
\hline Mil 7.1a & 0,64 & 0 \\
\hline Mil 7.1b & 0,31 & 0 \\
\hline Mil 7.2a & 1,62 & 0 \\
\hline Mil 7.2b & 1,08 & 0 \\
\hline Mil 7.3a & 0,64 & 0 \\
\hline Mil 7.3b & 1,15 & - \\
\hline Mil 7.4a & - & - \\
\hline Mil 7.4b & - & \\
\hline
\end{tabular}

\section{CORPO 8}

\begin{tabular}{|c|c|c|}
\hline & MARGEM GENGIVAL & MARGEM OCLUSAL \\
\hline Mil 8.1a & 0 & 0 \\
\hline Mil 8.1b & 0 & 0 \\
\hline Mil 8.2a & 0 & 0 \\
\hline Mil 8.2b & 0 & 0 \\
\hline Mil 8.3a & 0 & 0 \\
\hline Mil 8.3b & 0 & 0 \\
\hline Mil 8.4a & 0 & 0 \\
\hline Mil 8.4b & 0 & 0 \\
\hline
\end{tabular}

CORPO 9

\begin{tabular}{|c|c|c|}
\hline & MARGEM GENGIVAL & MARGEM OCLUSAL \\
\hline Mil 9.1a & 0,33 & 0 \\
\hline Mil 9.1b & 0,29 & 0 \\
\hline Mil 9.2a & 0,17 & 0 \\
\hline Mil 9.2b & 0,26 & 0 \\
\hline Mil 9.3a & 0,09 & 0 \\
\hline Mil 9.3b & 0,13 & - \\
\hline Mil 9.4a & - & - \\
\hline Mil 9.4b & - & \\
\hline
\end{tabular}

CORPO 10

\begin{tabular}{|c|c|c|}
\hline & MARGEM GENGIVAL & MARGEM OCLUSAL \\
\hline Mil 10.1a & 0 & 0 \\
\hline Mil 10.1b & 0 & 0 \\
\hline Mil 10.2a & 0 & 0 \\
\hline Mil 10.2b & 0 & 0 \\
\hline Mil 10.3a & 0 & 0,04 \\
\hline Mil 10.3b & 0 & - \\
\hline Mil 10.4a & - & - \\
\hline Mil 10.4b & - & 0 \\
\hline
\end{tabular}


CORPO 11

\begin{tabular}{|c|c|c|}
\hline & MARGEM GENGIVAL & MARGEM OCLUSAL \\
\hline Mil 11.1a & 0,03 & 0 \\
\hline Mil 11.1b & 0,02 & 0 \\
\hline Mil 11.2a & 0 & 0 \\
\hline Mil 11.2b & 0 & 0 \\
\hline Mil 11.3a & 0,02 & 0 \\
\hline Mil 11.3b & 0,03 & 0 \\
\hline Mil 11.4a & 0,03 & 0 \\
\hline Mil 11.4b & 0,02 & \\
\hline
\end{tabular}

\section{CORPO 12}

\begin{tabular}{|c|c|c|}
\hline & MARGEM GENGIVAL & MARGEM OCLUSAL \\
\hline Mil 12.1a & 0 & 0 \\
\hline Mil 12.1b & 0 & 0 \\
\hline Mil 12.2a & 0,02 & 0 \\
\hline Mil 12.2b & 0,02 & 0 \\
\hline Mil 12.3a & - & - \\
\hline Mil 12.3b & - & - \\
\hline Mil 12.4a & - & - \\
\hline Mil 12.4b & - & - \\
\hline
\end{tabular}

\section{CORPO 13}

\begin{tabular}{|c|c|c|}
\hline & MARGEM GENGIVAL & MARGEM OCLUSAL \\
\hline Mil 13.1a & 0 & 0,11 \\
\hline Mil 13.1b & 0 & 0,08 \\
\hline Mil 13.2a & 0 & 0,11 \\
\hline Mil 13.2b & 0 & 0,11 \\
\hline Mil 13.3a & 0 & 0,87 \\
\hline Mil 13.3b & 0 & 0,43 \\
\hline Mil 13.4a & - & - \\
\hline Mil 13.4b & - & - \\
\hline
\end{tabular}

\section{CORPO 14}

\begin{tabular}{|c|c|c|}
\hline & MARGEM GENGIVAL & MARGEM OCLUSAL \\
\hline Mil 14.1a & 0,18 & 0,19 \\
\hline Mil 14.1b & 0,22 & 0,16 \\
\hline Mil 14.2a & 0,32 & 0,03 \\
\hline Mil 14.2b & 0,30 & 0,06 \\
\hline Mil 14.3a & 0,18 & 0,17 \\
\hline Mil 14.3b & 0,20 & 0,18 \\
\hline Mil 14.4a & - & - \\
\hline Mil 14.4b & - & - \\
\hline
\end{tabular}




\section{CORPO 15}

\begin{tabular}{|c|c|c|}
\hline & MARGEM GENGIVAL & MARGEM OCLUSAL \\
\hline Mil 15.1a & 0,12 & 0 \\
\hline Mil 15.1b & 0,14 & 0 \\
\hline Mil 15.2a & 0,09 & 0 \\
\hline Mil 15.2b & 0,08 & 0 \\
\hline Mil 15.3a & 0,12 & 0 \\
\hline Mil 15.3b & 0,09 & - \\
\hline Mil 15.4a & - & - \\
\hline Mil 15.4b & - & 0 \\
\hline
\end{tabular}

\section{CORPO 16}

\begin{tabular}{|c|c|c|}
\hline & MARGEM GENGIVAL & MARGEM OCLUSAL \\
\hline Mil 16.1a & 0,22 & 0 -sem restauração \\
\hline Mil 16.1b & 0,18 & 0 -sem restauração \\
\hline Mil 16.2a & 0,34 & 0 -sem restauração \\
\hline Mil 16.2b & 0,51 & 0 -sem restauração \\
\hline Mil 16.3a & 0,16 & 0 -sem restauração \\
\hline Mil 16.3b & 0,10 & 0 -sem restauração \\
\hline Mil 16.4a & - & - \\
\hline Mil 16.4b & - & - \\
\hline
\end{tabular}

\section{CORPO 17}

\begin{tabular}{|c|c|c|}
\hline & MARGEM GENGIVAL & MARGEM OCLUSAL \\
\hline Mil 17.1a & 0 & 0 \\
\hline Mil 17.1b & 0 & 0 \\
\hline Mil 17.2a & 0 & 0 \\
\hline Mil 17.2b & 0 & 0 \\
\hline Mil 17.3a & 0 & 0 \\
\hline Mil 17.3b & 0 & 0 \\
\hline Mil 17.4a & 0 & 0 \\
\hline Mil 17.4b & 0 & 0 \\
\hline
\end{tabular}

\section{CORPO 18}

\begin{tabular}{|c|c|c|}
\hline & MARGEM GENGIVAL & MARGEM OCLUSAL \\
\hline Mil 18.1a & 0-entrou pelo 1mm & 0,10 \\
\hline Mil 18.1b & 0-entrou pelo 1mm & 0,17 \\
\hline Mil 18.2a & 0-entrou pelo 1mm & 0,11 \\
\hline Mil 18.2b & 0-entrou pelo 1mm & 0,14 \\
\hline Mil 18.3a & 0-entrou pelo 1mm & 0,09 \\
\hline Mil 18.3b & 0-entrou pelo 1mm & - \\
\hline Mil 18.4a & - & - \\
\hline Mil 18.4b & - & \\
\hline
\end{tabular}




\section{CORPO 19}

\begin{tabular}{|c|c|c|}
\hline & MARGEM GENGIVAL & MARGEM OCLUSAL \\
\hline Mil 19.1a & 0 & 0-entrou pelo 1mm \\
\hline Mil 19.1b & 0,02 & 0-entrou pelo 1mm \\
\hline Mil 19.2a & 0,03 & 0-entrou pelo 1mm \\
\hline Mil 19.2b & 0,02 & 0-entrou pelo $1 \mathrm{~mm}$ \\
\hline Mil 19.3a & 0 & 0-entrou pelo $1 \mathrm{~mm}$ \\
\hline Mil 19.3b & 0 & 0-entrou pelo $1 \mathrm{~mm}$ \\
\hline Mil 19.4a & - & - \\
\hline Mil 19.4b & - & - \\
\hline
\end{tabular}

LEITURA POR ESCORES

\section{GRUPO DE NENHUM CICLO}

\section{CORPO 1}

\begin{tabular}{|c|c|c|}
\hline & MARGEM GENGIVAL & MARGEM OCLUSAL \\
\hline Zero 1.1a & 0 & 0 \\
\hline Zero 1.1b & 0 & 0 \\
\hline Zero 1.2a & 0 & 0 \\
\hline Zero 1.2b & 0 & 0 \\
\hline Zero 1.3a & 0 & 0 \\
\hline Zero 1.3b & 0 & 0 \\
\hline Zero 1.4a & 0 & 0 \\
\hline Zero 1.4b & 0 & 0 \\
\hline
\end{tabular}

\section{CORPO 2}

\begin{tabular}{|c|c|c|}
\hline & MARGEM GENGIVAL & MARGEM OCLUSAL \\
\hline Zero 2.1a & 0 & 0 \\
\hline Zero 2.1b & 0 & 0 \\
\hline Zero 2.2a & 0 & 0 \\
\hline Zero 2.2b & 0 & 0 \\
\hline Zero 2.3a & 0 & 0 \\
\hline Zero 2.3b & 0 & 0 \\
\hline Zero 2.4a & 0 & 0 \\
\hline Zero 2.4b & 0 & 0 \\
\hline
\end{tabular}


CORPO 3

\begin{tabular}{|c|c|c|}
\hline & MARGEM GENGIVAL & MARGEM OCLUSAL \\
\hline Zero 3.1a & 0 & 0 \\
\hline Zero 3.1b & 0 & 0 \\
\hline Zero 3.2a & 0 & 0 \\
\hline Zero 3.2b & 0 & 0 \\
\hline Zero 3.3a & 0 & 0 \\
\hline Zero 3.3b & 0 & 0 \\
\hline Zero 3.4a & 0 & 0 \\
\hline Zero 3.4b & 0 & 0 \\
\hline
\end{tabular}

\section{CORPO 4}

\begin{tabular}{|c|c|c|}
\hline & MARGEM GENGIVAL & MARGEM OCLUSAL \\
\hline Zero 4.1a & 0 & 0 \\
\hline Zero 4.1b & 0 & 0 \\
\hline Zero 4.2a & 0 & 0 \\
\hline Zero 4.2b & 0 & 0 \\
\hline Zero 4.3a & 0 & 0 \\
\hline Zero 4.3b & 0 & 0 \\
\hline Zero 4.4a & 0 & 0 \\
\hline Zero 4.4b & 0 & 0 \\
\hline
\end{tabular}

\section{CORPO 5}

\begin{tabular}{|c|c|c|}
\hline & MARGEM GENGIVAL & MARGEM OCLUSAL \\
\hline Zero 5.1a & 0 & 0 \\
\hline Zero 5.1b & 0 & 0 \\
\hline Zero 5.2a & 0 & 0 \\
\hline Zero 5.2b & 0 & 0 \\
\hline Zero 5.3a & 0 & 0 \\
\hline Zero 5.3b & 0 & 0 \\
\hline Zero 5.4a & 0 & 0 \\
\hline Zero 5.4b & 0 & \\
\hline
\end{tabular}

\section{CORPO 6}

\begin{tabular}{|c|c|c|}
\hline & MARGEM GENGIVAL & MARGEM OCLUSAL \\
\hline Zero 6.1a & 0 & 0 \\
\hline Zero 6.1b & 0 & 0 \\
\hline Zero 6.2a & 0 & 0 \\
\hline Zero 6.2b & 0 & 0 \\
\hline Zero 6.3a & 0 & 0 \\
\hline Zero 6.3b & 0 & 0 \\
\hline Zero 6.4a & 0 & 0 \\
\hline Zero 6.4b & 0 & 0 \\
\hline
\end{tabular}


CORPO 7

\begin{tabular}{|c|c|c|}
\hline & MARGEM GENGIVAL & MARGEM OCLUSAL \\
\hline Zero 7.1a & 0 & 0 \\
\hline Zero 7.1b & 0 & 0 \\
\hline Zero 7.2a & 0 & 0 \\
\hline Zero 7.2b & 0 & 0 \\
\hline Zero 7.3a & 0 & 0 \\
\hline Zero 7.3b & 0 & 0 \\
\hline Zero 7.4a & 0 & 0 \\
\hline Zero 7.4b & 0 & 0 \\
\hline
\end{tabular}

\section{CORPO 8}

\begin{tabular}{|c|c|c|}
\hline & MARGEM GENGIVAL & MARGEM OCLUSAL \\
\hline Zero 8.1a & 0 & 0 \\
\hline Zero 8.1b & 0 & 0 \\
\hline Zero 8.2a & 0 & 0 \\
\hline Zero 8.2b & 0 & 0 \\
\hline Zero 8.3a & 0 & 0 \\
\hline Zero 8.3b & 0 & 0 \\
\hline Zero 8.4a & 0 & 0 \\
\hline Zero 8.4b & 0 & 0 \\
\hline
\end{tabular}

\section{CORPO 9}

\begin{tabular}{|c|c|c|}
\hline & MARGEM GENGIVAL & MARGEM OCLUSAL \\
\hline Zero 9.1a & 0 & 0 \\
\hline Zero 9.1b & 0 & 0 \\
\hline Zero 9.2a & 0 & 0 \\
\hline Zero 9.2b & 0 & 0 \\
\hline Zero 9.3a & 0 & 0 \\
\hline Zero 9.3b & 0 & 0 \\
\hline Zero 9.4a & 0 & 0 \\
\hline Zero 9.4b & 0 & \\
\hline
\end{tabular}

\section{CORPO 10}

\begin{tabular}{|c|c|c|}
\hline & MARGEM GENGIVAL & MARGEM OCLUSAL \\
\hline Zero 10.1a & 0-sem restauração & 0-sem restauração \\
\hline Zero 10.1b & 0-sem restauração & 0-sem restauração \\
\hline Zero 10.2a & 1 & 1 \\
\hline Zero 10.2b & 1 & 1 \\
\hline Zero 10.3a & 1 & 1 \\
\hline Zero 10.3b & 1 & 1 \\
\hline Zero 10.4a & 0 & 1 \\
\hline Zero 10.4b & 0 & 1 \\
\hline
\end{tabular}




\section{CORPO 11}

\begin{tabular}{|c|c|c|}
\hline & MARGEM GENGIVAL & MARGEM OCLUSAL \\
\hline Zero 11.1a & 0-sem restauração & 0-sem restauração \\
\hline Zero 11.1b & 0-sem restauração & 0-sem restauração \\
\hline Zero 11.2a & 0 & 1 \\
\hline Zero 11.2b & 0 & 1 \\
\hline Zero 11.3a & 0 & 1 \\
\hline Zero 11.3b & 0 & 1 \\
\hline Zero 11.4a & 0 & 1 \\
\hline Zero 11.4b & 0 & 1 \\
\hline
\end{tabular}

\section{CORPO 12}

\begin{tabular}{|c|c|c|}
\hline & MARGEM GENGIVAL & MARGEM OCLUSAL \\
\hline Zero 12.1a & 1 & 0 \\
\hline Zero 12.1b & 1 & 0 \\
\hline Zero 12.2a & 0 & 0 \\
\hline Zero 12.2b & 1 & 0 \\
\hline Zero 12.3a & 1 & 0 \\
\hline Zero 12.3b & 1 & 0-sem restauração \\
\hline Zero 12.4a & 0-Sem restauração & 0-sem restauração \\
\hline Zero 12.4b & 0-sem restauração & \\
\hline
\end{tabular}

\section{CORPO 13}

\begin{tabular}{|c|c|c|}
\hline & MARGEM GENGIVAL & MARGEM OCLUSAL \\
\hline Zero 13.1a & 0-sem restauração & 0-sem restauração \\
\hline Zero 13.1b & 0-sem restauração & 0-sem restauração \\
\hline Zero 13.2a & 0 & 0 \\
\hline Zero 13.2b & 0 & 0 \\
\hline Zero 13.3a & 0 & 0 \\
\hline Zero 13.3b & 0 & 0 \\
\hline Zero 13.4a & 0 & 0 \\
\hline Zero 13.4b & 0 & 0 \\
\hline
\end{tabular}

\section{CORPO 14}

\begin{tabular}{|c|c|c|}
\hline & MARGEM GENGIVAL & MARGEM OCLUSAL \\
\hline Zero 13.1a & 0-sem restauração & 0-sem restauração \\
\hline Zero 13.1b & 0-sem restauração & 0-sem restauração \\
\hline Zero 13.2a & 0 & 0 \\
\hline Zero 13.2b & 0 & 0 \\
\hline Zero 13.3a & 0 & 1 \\
\hline Zero 13.3b & 0 & 0-sem restauração \\
\hline Zero 13.4a & 0-sem restauração & 0-sem restauração \\
\hline Zero 13.4b & 0-sem restauração & \\
\hline
\end{tabular}




\section{CORPO 15}

\begin{tabular}{|c|c|c|}
\hline & MARGEM GENGIVAL & MARGEM OCLUSAL \\
\hline Zero 15.1a & 0 & 0 \\
\hline Zero 15.1b & 1 & 0 \\
\hline Zero 15.2a & 0 & 0 \\
\hline Zero 15.2b & 0 & 0 \\
\hline Zero 15.3a & 0 & 0 \\
\hline Zero 15.3b & 0 & - \\
\hline Zero 15.4a & - & - \\
\hline Zero 15.4b & - & 0 \\
\hline
\end{tabular}

\section{CORPO 16}

\begin{tabular}{|c|c|c|}
\hline & MARGEM GENGIVAL & MARGEM OCLUSAL \\
\hline Zero 16.1a & 0 & 0 \\
\hline Zero 16.1b & 0 & 0 \\
\hline Zero 16.2a & 1 & 0 \\
\hline Zero 16.2b & 0 & - \\
\hline Zero 16.3a & - & - \\
\hline Zero 16.3b & - & - \\
\hline Zero 16.4a & - & - \\
\hline Zero 16.4b & - & 0 \\
\hline
\end{tabular}

\section{CORPO 17}

\begin{tabular}{|c|c|c|}
\hline & MARGEM GENGIVAL & MARGEM OCLUSAL \\
\hline Zero 17.1a & 1 & 0 \\
\hline Zero 17.1b & 1 & 0 \\
\hline Zero 17.2a & 1 & 0 \\
\hline Zero 17.2b & 1 & 0 \\
\hline Zero 17.3a & 0 & 0 \\
\hline Zero 17.3b & 0 & - \\
\hline Zero 17.4a & - & - \\
\hline Zero 17.4b & - & 0 \\
\hline
\end{tabular}

\section{CORPO 18}

\begin{tabular}{|c|c|c|}
\hline & MARGEM GENGIVAL & MARGEM OCLUSAL \\
\hline Zero 18.1a & 0 & 0 \\
\hline Zero 18.1b & 1 & 0 \\
\hline Zero 18.2a & 0 & 0 \\
\hline Zero 18.2b & 0 & 0 \\
\hline Zero 18.3a & 2 & 0 \\
\hline Zero 18.3b & 2 & - \\
\hline Zero 18.4a & - & - \\
\hline Zero 18.4b & - & 0 \\
\hline
\end{tabular}




\section{CORPO 19}

\begin{tabular}{|c|c|c|}
\hline & MARGEM GENGIVAL & MARGEM OCLUSAL \\
\hline Zero 19.1a & 0-sem restauração & 0-sem restauração \\
\hline Zero 19.1b & 0-sem restauração & 0-sem restauração \\
\hline Zero 19.2a & 1 & 2 \\
\hline Zero 19.2b & 1 & 2 \\
\hline Zero 19.3a & 0 & 0 \\
\hline Zero 19.3b & 0 & 0 \\
\hline Zero 19.4a & 0 & 1 \\
\hline Zero 19.4b & 0 & 1 \\
\hline
\end{tabular}

\section{GRUPO DE 100 CICLOS}

\section{CORPO 1}

\begin{tabular}{|c|c|c|}
\hline & MARGEM GENGIVAL & MARGEM OCLUSAL \\
\hline Cem 1.1a & 0 & 0 \\
\hline Cem $1.1 \mathrm{~b}$ & 0 & 0 \\
\hline Cem $1.2 \mathrm{a}$ & 4 & 0 \\
\hline Cem $1.2 \mathrm{~b}$ & 4 & 0 \\
\hline Cem $1.3 \mathrm{a}$ & 4 & 0 \\
\hline Cem $1.3 \mathrm{~b}$ & 4 & 0 \\
\hline Cem $1.4 \mathrm{a}$ & - & - \\
\hline Cem $1.4 \mathrm{~b}$ & - & - \\
\hline
\end{tabular}

\section{CORPO 2}

\begin{tabular}{|c|c|c|}
\hline & MARGEM GENGIVAL & MARGEM OCLUSAL \\
\hline Cem 2.1a & 2 & 0 \\
\hline Cem 2.1b & 3 & 0 \\
\hline Cem 2.2a & 3 & 0 \\
\hline Cem 2.2b & 4 & 0 \\
\hline Cem 2.3a & 4 & 0 \\
\hline Cem 2.3b & 4 & 0 \\
\hline Cem 2.4a & - & - \\
\hline Cem 2.4b & - & - \\
\hline
\end{tabular}

\section{CORPO 3}

\begin{tabular}{|c|c|c|}
\hline & MARGEM GENGIVAL & MARGEM OCLUSAL \\
\hline Cem 3.1a & 0-sem restauração & 0-sem restauração \\
\hline Cem 3.1b & 3 & 0 \\
\hline Cem 3.2a & 1 & 0 \\
\hline Cem 3.2b & 1 & 0 \\
\hline Cem 3.3a & 1 & 0 \\
\hline Cem 3.3b & 1 & 0 \\
\hline Cem 3.4a & 1 & 0 \\
\hline Cem 3.4b & 0 & 0 \\
\hline
\end{tabular}


CORPO 4

\begin{tabular}{|c|c|c|}
\hline & MARGEM GENGIVAL & MARGEM OCLUSAL \\
\hline Cem 4.1a & 3 & 0-entrou pelo 1mm \\
\hline Cem 4.1b & 0 & 0-entrou pelo $1 \mathrm{~mm}$ \\
\hline Cem 4.2a & 0 & 0-entrou pelo $1 \mathrm{~mm}$ \\
\hline Cem 4.2b & 0 & 0-entrou pelo $1 \mathrm{~mm}$ \\
\hline Cem 4.3a & 0 & 0-entrou pelo $1 \mathrm{~mm}$ \\
\hline Cem 4.3b & 0 & 0-entrou pelo $1 \mathrm{~mm}$ \\
\hline Cem 4.4a & 1 & 0-entrou pelo $1 \mathrm{~mm}$ \\
\hline Cem 4.4b & 0-sem restauração & 0-sem restauração \\
\hline
\end{tabular}

\section{CORPO 5}

\begin{tabular}{|c|c|c|}
\hline & MARGEM GENGIVAL & MARGEM OCLUSAL \\
\hline Cem 5.1a & 3 & 1 \\
\hline Cem 5.1b & 4 & 0 \\
\hline Cem 5.2a & 4 & 0 \\
\hline Cem 5.2b & 4 & 0 \\
\hline Cem 5.3a & 2 & 1 \\
\hline Cem 5.3b & 1 & 0-sem restauração \\
\hline Cem 5.4a & 0-sem restauração & 0-sem restauração \\
\hline Cem 5.4b & 0-sem restauração & . \\
\hline
\end{tabular}

\section{CORPO 6}

\begin{tabular}{|c|c|c|}
\hline & MARGEM GENGIVAL & MARGEM OCLUSAL \\
\hline Cem 6.1a & 0-sem restauração & 0-sem restauração \\
\hline Cem 6.1b & 0-sem restauração & 0-sem restauração \\
\hline Cem 6.2a & 4 & 0 \\
\hline Cem 6.2b & 4 & 0 \\
\hline Cem 6.3a & 4 & 0 \\
\hline Cem 6.3b & 4 & 0 \\
\hline Cem 6.4a & 0-sem restauração & 0-sem restauração \\
\hline Cem 6.4b & 0-sem restauração & 0-sem restauração \\
\hline
\end{tabular}

\section{CORPO 7}

\begin{tabular}{|c|c|c|}
\hline & MARGEM GENGIVAL & MARGEM OCLUSAL \\
\hline Cem 7.1a & 0-entrou pelo $1 \mathrm{~mm}$ & 0-entrou pelo 1mm \\
\hline Cem 7.1b & 0-entrou pelo $1 \mathrm{~mm}$ & 0-entrou pelo 1mm \\
\hline Cem 7.2a & 0-entrou pelo $1 \mathrm{~mm}$ & 0-entrou pelo $1 \mathrm{~mm}$ \\
\hline Cem 7.2b & 0-entrou pelo $1 \mathrm{~mm}$ & 0-entrou pelo $1 \mathrm{~mm}$ \\
\hline Cem 7.3a & 0-entrou pelo $1 \mathrm{~mm}$ & 0-entrou pelo $1 \mathrm{~mm}$ \\
\hline Cem 7.3b & 0-entrou pelo $1 \mathrm{~mm}$ & 0-entrou pelo $1 \mathrm{~mm}$ \\
\hline Cem 7.4a & 0-entrou pelo $1 \mathrm{~mm}$ & 0-entrou pelo $1 \mathrm{~mm}$ \\
\hline Cem 7.4b & 0-entrou pelo $1 \mathrm{~mm}$ & 0-entrou pelo $1 \mathrm{~mm}$ \\
\hline
\end{tabular}


CORPO 8

\begin{tabular}{|c|c|c|}
\hline & MARGEM GENGIVAL & MARGEM OCLUSAL \\
\hline Cem 8.1a & 0-entrou pelo $1 \mathrm{~mm}$ & 0-entrou pelo $1 \mathrm{~mm}$ \\
\hline Cem 8.1b & 0-entrou pelo $1 \mathrm{~mm}$ & 0-entrou pelo $1 \mathrm{~mm}$ \\
\hline Cem 8.2a & 0-entrou pelo $1 \mathrm{~mm}$ & 0-entrou pelo $1 \mathrm{~mm}$ \\
\hline Cem 8.2b & 0-entrou pelo $1 \mathrm{~mm}$ & 0-entrou pelo $1 \mathrm{~mm}$ \\
\hline Cem 8.3a & 0-entrou pelo $1 \mathrm{~mm}$ & 0-entrou pelo $1 \mathrm{~mm}$ \\
\hline Cem 8.3b & 0-entrou pelo $1 \mathrm{~mm}$ & 0-entrou pelo $1 \mathrm{~mm}$ \\
\hline Cem 8.4a & 0-entrou pelo $1 \mathrm{~mm}$ & 0-entrou pelo $1 \mathrm{~mm}$ \\
\hline Cem 8.4b & 0-entrou pelo $1 \mathrm{~mm}$ & 0-entrou pelo $1 \mathrm{~mm}$ \\
\hline
\end{tabular}

\section{CORPO 9}

\begin{tabular}{|c|c|c|}
\hline & MARGEM GENGIVAL & MARGEM OCLUSAL \\
\hline Cem 9.1a & 0 & 0 \\
\hline Cem 9.1b & 0 & 0 \\
\hline Cem 9.2a & 0 & 0 \\
\hline Cem 9.2b & 1 & 0 \\
\hline Cem 9.3a & 1 & 0 \\
\hline Cem 9.3b & 1 & - \\
\hline Cem 9.4a & - & - \\
\hline Cem 9.4b & - & \\
\hline
\end{tabular}

\section{CORPO 10}

\begin{tabular}{|c|c|c|}
\hline & MARGEM GENGIVAL & MARGEM OCLUSAL \\
\hline Cem 10.1a & 0-entrou pelo $1 \mathrm{~mm}$ & 0-entrou pelo $1 \mathrm{~mm}$ \\
\hline Cem 10.1b & 0-entrou pelo $1 \mathrm{~mm}$ & 0-entrou pelo $1 \mathrm{~mm}$ \\
\hline Cem 10.2a & 0-entrou pelo $1 \mathrm{~mm}$ & 0-entrou pelo $1 \mathrm{~mm}$ \\
\hline Cem 10.2b & 0-entrou pelo $1 \mathrm{~mm}$ & 0-entrou pelo $1 \mathrm{~mm}$ \\
\hline Cem 10.3a & 0-entrou pelo $1 \mathrm{~mm}$ & 0-entrou pelo $1 \mathrm{~mm}$ \\
\hline Cem 10.3b & 0-entrou pelo $1 \mathrm{~mm}$ & 0-entrou pelo $1 \mathrm{~mm}$ \\
\hline Cem 10.4a & 0-entrou pelo $1 \mathrm{~mm}$ & 0-entrou pelo $1 \mathrm{~mm}$ \\
\hline Cem 10.4b & 0-entrou pelo $1 \mathrm{~mm}$ & 0-entrou pelo $1 \mathrm{~mm}$ \\
\hline
\end{tabular}

\section{CORPO 11}

\begin{tabular}{|c|c|c|}
\hline & MARGEM GENGIVAL & MARGEM OCLUSAL \\
\hline Cem 11.1a & 0-entrou pelo $1 \mathrm{~mm}$ & 0-entrou pelo $1 \mathrm{~mm}$ \\
\hline Cem 11.1b & 0-entrou pelo $1 \mathrm{~mm}$ & 0-entrou pelo $1 \mathrm{~mm}$ \\
\hline Cem 11.2a & 0-entrou pelo $1 \mathrm{~mm}$ & 0-entrou pelo $1 \mathrm{~mm}$ \\
\hline Cem 11.2b & 0-entrou pelo $1 \mathrm{~mm}$ & 0-entrou pelo $1 \mathrm{~mm}$ \\
\hline Cem 11.3a & 0-entrou pelo $1 \mathrm{~mm}$ & 0-entrou pelo $1 \mathrm{~mm}$ \\
\hline Cem 11.3b & 0-entrou pelo $1 \mathrm{~mm}$ & 0-entrou pelo $1 \mathrm{~mm}$ \\
\hline Cem 11.4a & 0-entrou pelo $1 \mathrm{~mm}$ & 0-entrou pelo $1 \mathrm{~mm}$ \\
\hline Cem 11.4b & 0-entrou pelo $1 \mathrm{~mm}$ & 0-entrou pelo $1 \mathrm{~mm}$ \\
\hline
\end{tabular}


CORPO 12

\begin{tabular}{|c|c|c|}
\hline & MARGEM GENGIVAL & MARGEM OCLUSAL \\
\hline Cem 12.1a & 0-entrou pelo $1 \mathrm{~mm}$ & 0-entrou pelo $1 \mathrm{~mm}$ \\
\hline Cem 12.1b & 0-entrou pelo $1 \mathrm{~mm}$ & 0-entrou pelo $1 \mathrm{~mm}$ \\
\hline Cem 12.2a & 0-entrou pelo $1 \mathrm{~mm}$ & 0-entrou pelo $1 \mathrm{~mm}$ \\
\hline Cem 12.2b & 0-entrou pelo $1 \mathrm{~mm}$ & 0-entrou pelo $1 \mathrm{~mm}$ \\
\hline Cem 12.3a & 0-entrou pelo $1 \mathrm{~mm}$ & 0-entrou pelo $1 \mathrm{~mm}$ \\
\hline Cem 12.3b & 0-entrou pelo $1 \mathrm{~mm}$ & 0-entrou pelo $1 \mathrm{~mm}$ \\
\hline Cem 12.4a & 0-entrou pelo $1 \mathrm{~mm}$ & 0-entrou pelo $1 \mathrm{~mm}$ \\
\hline Cem 12.4b & 0-entrou pelo $1 \mathrm{~mm}$ & 0-entrou pelo $1 \mathrm{~mm}$ \\
\hline
\end{tabular}

\section{CORPO 13}

\begin{tabular}{|c|c|c|}
\hline & MARGEM GENGIVAL & MARGEM OCLUSAL \\
\hline Cem 13.1a & 0-entrou pelo $1 \mathrm{~mm}$ & 0-entrou pelo $1 \mathrm{~mm}$ \\
\hline Cem 13.1b & 0-entrou pelo $1 \mathrm{~mm}$ & 0-entrou pelo $1 \mathrm{~mm}$ \\
\hline Cem 13.2a & 0-entrou pelo $1 \mathrm{~mm}$ & 0-entrou pelo $1 \mathrm{~mm}$ \\
\hline Cem 13.2b & 0-entrou pelo $1 \mathrm{~mm}$ & 0-entrou pelo $1 \mathrm{~mm}$ \\
\hline Cem 13.3a & 0-entrou pelo $1 \mathrm{~mm}$ & 0-entrou pelo $1 \mathrm{~mm}$ \\
\hline Cem 13.3b & 0-entrou pelo $1 \mathrm{~mm}$ & 0-entrou pelo $1 \mathrm{~mm}$ \\
\hline Cem 13.4a & 0-entrou pelo $1 \mathrm{~mm}$ & 0-entrou pelo $1 \mathrm{~mm}$ \\
\hline Cem 13.4b & 0-entrou pelo $1 \mathrm{~mm}$ & 0-entrou pelo $1 \mathrm{~mm}$ \\
\hline
\end{tabular}

\section{CORPO 14}

\begin{tabular}{|c|c|c|}
\hline & MARGEM GENGIVAL & MARGEM OCLUSAL \\
\hline Cem 14.1a & 4 & 0 \\
\hline Cem 14.1b & 4 & 0 \\
\hline Cem 14.2a & 4 & 0 \\
\hline Cem 14.2b & 3 & 0 \\
\hline Cem 14.3a & 3 & 0 \\
\hline Cem 14.3b & 3 & - \\
\hline Cem 14.4a & - & - \\
\hline Cem 14.4b & - & 0 \\
\hline
\end{tabular}

\section{CORPO 15}

\begin{tabular}{|c|c|c|}
\hline & MARGEM GENGIVAL & MARGEM OCLUSAL \\
\hline Cem 15.1a & 0-entrou pelo $1 \mathrm{~mm}$ & 0-entrou pelo $1 \mathrm{~mm}$ \\
\hline Cem 15.1b & 0-entrou pelo $1 \mathrm{~mm}$ & 0-entrou pelo $1 \mathrm{~mm}$ \\
\hline Cem 15.2a & 0-entrou pelo $1 \mathrm{~mm}$ & 0-entrou pelo $1 \mathrm{~mm}$ \\
\hline Cem 15.2b & 0-entrou pelo $1 \mathrm{~mm}$ & 0-entrou pelo $1 \mathrm{~mm}$ \\
\hline Cem 15.3a & 0-entrou pelo $1 \mathrm{~mm}$ & 0-entrou pelo $1 \mathrm{~mm}$ \\
\hline Cem 15.3b & 0-entrou pelo $1 \mathrm{~mm}$ & 0-entrou pelo $1 \mathrm{~mm}$ \\
\hline Cem 15.4a & 0-entrou pelo $1 \mathrm{~mm}$ & 0-entrou pelo $1 \mathrm{~mm}$ \\
\hline Cem $15.4 \mathrm{~b}$ & 0-entrou pelo $1 \mathrm{~mm}$ & 0-entrou pelo $1 \mathrm{~mm}$ \\
\hline
\end{tabular}


CORPO 16

\begin{tabular}{|c|c|c|}
\hline & MARGEM GENGIVAL & MARGEM OCLUSAL \\
\hline Cem 16.1a & 0-entrou pelo $1 \mathrm{~mm}$ & 0-entrou pelo $1 \mathrm{~mm}$ \\
\hline Cem 16.1b & 0-entrou pelo $1 \mathrm{~mm}$ & 0-entrou pelo $1 \mathrm{~mm}$ \\
\hline Cem 16.2a & 0-entrou pelo $1 \mathrm{~mm}$ & 0-entrou pelo $1 \mathrm{~mm}$ \\
\hline Cem 16.2b & 0-entrou pelo $1 \mathrm{~mm}$ & 0-entrou pelo $1 \mathrm{~mm}$ \\
\hline Cem 16.3a & 0-entrou pelo $1 \mathrm{~mm}$ & 0-entrou pelo $1 \mathrm{~mm}$ \\
\hline Cem 16.3b & 0-entrou pelo $1 \mathrm{~mm}$ & 0-entrou pelo $1 \mathrm{~mm}$ \\
\hline Cem 16.4a & 0-entrou pelo $1 \mathrm{~mm}$ & 0-entrou pelo $1 \mathrm{~mm}$ \\
\hline Cem 16.4b & 0-entrou pelo $1 \mathrm{~mm}$ & 0-entrou pelo $1 \mathrm{~mm}$ \\
\hline
\end{tabular}

\section{CORPO 17}

\begin{tabular}{|c|c|c|}
\hline & MARGEM GENGIVAL & MARGEM OCLUSAL \\
\hline Cem 17.1a & 0-entrou pelo $1 \mathrm{~mm}$ & 0-entrou pelo $1 \mathrm{~mm}$ \\
\hline Cem 17.1b & 0-entrou pelo $1 \mathrm{~mm}$ & 0-entrou pelo $1 \mathrm{~mm}$ \\
\hline Cem 17.2a & 0-entrou pelo $1 \mathrm{~mm}$ & 0-entrou pelo $1 \mathrm{~mm}$ \\
\hline Cem 17.2b & 0-entrou pelo $1 \mathrm{~mm}$ & 0-entrou pelo $1 \mathrm{~mm}$ \\
\hline Cem 17.3a & 0-entrou pelo $1 \mathrm{~mm}$ & 0-entrou pelo $1 \mathrm{~mm}$ \\
\hline Cem 17.3b & 0-entrou pelo $1 \mathrm{~mm}$ & 0-entrou pelo $1 \mathrm{~mm}$ \\
\hline Cem 17.4a & 0-entrou pelo $1 \mathrm{~mm}$ & 0-entrou pelo $1 \mathrm{~mm}$ \\
\hline Cem 17.4b & 0-entrou pelo $1 \mathrm{~mm}$ & 0-entrou pelo $1 \mathrm{~mm}$ \\
\hline
\end{tabular}

\section{CORPO 18}

\begin{tabular}{|c|c|c|}
\hline & MARGEM GENGIVAL & MARGEM OCLUSAL \\
\hline Cem 18.1a & 1 & 0 \\
\hline Cem 18.1b & 0-sem restauração & 0 0- sem restauração \\
\hline Cem 18.2a & 0 & 0 \\
\hline Cem 18.2b & 0 & 0 \\
\hline Cem 18.3a & 2 & 0 \\
\hline Cem 18.3b & 1 & 0 \\
\hline Cem 18.4a & 0 & 0 \\
\hline Cem 18.4b & 0 & 0 \\
\hline
\end{tabular}

\section{CORPO 19}

\begin{tabular}{|c|c|c|}
\hline & MARGEM GENGIVAL & MARGEM OCLUSAL \\
\hline Cem 19.1a & 0-entrou pelo $1 \mathrm{~mm}$ & 0-entrou pelo $1 \mathrm{~mm}$ \\
\hline Cem 19.1b & 0-entrou pelo $1 \mathrm{~mm}$ & 0-entrou pelo $1 \mathrm{~mm}$ \\
\hline Cem 19.2a & 0-entrou pelo $1 \mathrm{~mm}$ & 0-entrou pelo $1 \mathrm{~mm}$ \\
\hline Cem 19.2b & 0-entrou pelo $1 \mathrm{~mm}$ & 0-entrou pelo $1 \mathrm{~mm}$ \\
\hline Cem 19.3a & 0-entrou pelo $1 \mathrm{~mm}$ & 0-entrou pelo $1 \mathrm{~mm}$ \\
\hline Cem 19.3b & 0-entrou pelo $1 \mathrm{~mm}$ & 0-entrou pelo $1 \mathrm{~mm}$ \\
\hline Cem 19.4a & 0-entrou pelo $1 \mathrm{~mm}$ & 0-entrou pelo $1 \mathrm{~mm}$ \\
\hline Cem 19.4b & 0-entrou pelo $1 \mathrm{~mm}$ & 0-entrou pelo $1 \mathrm{~mm}$ \\
\hline
\end{tabular}




\section{GRUPO DE 200 CICLOS}

\section{CORPO 1}

\begin{tabular}{|c|c|c|}
\hline & MARGEM GENGIVAL & MARGEM OCLUSAL \\
\hline Duze $1.1 \mathrm{a}$ & 0 & 0 \\
\hline Duze $1.1 \mathrm{~b}$ & 0 & 0 \\
\hline Duze $1.2 \mathrm{a}$ & 0 & 0 \\
\hline Duze $1.2 \mathrm{~b}$ & 0 & 0 \\
\hline Duze $1.3 \mathrm{a}$ & 0 & 0 \\
\hline Duze $1.3 \mathrm{~b}$ & 0 & 0 \\
\hline Duze $1.4 \mathrm{a}$ & 0 & 0 \\
\hline Duze $1.4 \mathrm{~b}$ & 0 & \\
\hline
\end{tabular}

\section{CORPO 2}

\begin{tabular}{|c|c|c|}
\hline & MARGEM GENGIVAL & MARGEM OCLUSAL \\
\hline Duze $2.1 \mathrm{a}$ & 0 & 0 \\
\hline Duze $2.1 \mathrm{~b}$ & 0 & 0 \\
\hline Duze $2.2 \mathrm{a}$ & 0 & 1 \\
\hline Duze $2.2 \mathrm{~b}$ & 0 & 1 \\
\hline Duze $2.3 \mathrm{a}$ & 0 & 1 \\
\hline Duze $2.3 \mathrm{~b}$ & 0 & 1 \\
\hline Duze $2.4 \mathrm{a}$ & 0 & 0 \\
\hline Duze $2.4 \mathrm{~b}$ & 0 & \\
\hline
\end{tabular}

\section{CORPO 3}

\begin{tabular}{|c|c|c|}
\hline & MARGEM GENGIVAL & MARGEM OCLUSAL \\
\hline Duze 3.1a & 0 & 0 \\
\hline Duze 3.1b & 0 & 0 \\
\hline Duze 3.2a & 0 & 0 \\
\hline Duze 3.2b & 0 & 0 \\
\hline Duze 3.3a & 0 & 0 \\
\hline Duze 3.3b & 0 & 0 \\
\hline Duze 3.4a & 0 & 0 \\
\hline Duze 3.4b & 0 & 0 \\
\hline
\end{tabular}

\section{CORPO 4}

\begin{tabular}{|c|c|c|}
\hline & MARGEM GENGIVAL & MARGEM OCLUSAL \\
\hline Duze 1.1a & 0-Corante entra $\mathrm{p} / 1 \mathrm{~mm}$ & 0-Corante entra $\mathrm{p} / 1 \mathrm{~mm}$ \\
\hline Duze 1.1b & 0-Corante entra $\mathrm{p} / 1 \mathrm{~mm}$ & 0-Corante entra $\mathrm{p} / 1 \mathrm{~mm}$ \\
\hline Duze 1.2a & 0-Corante entra $\mathrm{p} / 1 \mathrm{~mm}$ & 0-Corante entra $\mathrm{p} / 1 \mathrm{~mm}$ \\
\hline Duze 1.2b & 0-Corante entra $\mathrm{p} / 1 \mathrm{~mm}$ & 0-Corante entra $\mathrm{p} / 1 \mathrm{~mm}$ \\
\hline Duze.1.3a & 0-Corante entra $\mathrm{p} / 1 \mathrm{~mm}$ & 0-Corante entra $\mathrm{p} / 1 \mathrm{~mm}$ \\
\hline Duze 1.3b & 0-Corante entra $\mathrm{p} / 1 \mathrm{~mm}$ & 0-Corante entra $\mathrm{p} / 1 \mathrm{~mm}$ \\
\hline Duze 1.4a & 0-Corante entra $\mathrm{p} / 1 \mathrm{~mm}$ & 0-Corante entra $\mathrm{p} / 1 \mathrm{~mm}$ \\
\hline Duze $1.4 \mathrm{~b}$ & 0-Corante entra $\mathrm{p} / 1 \mathrm{~mm}$ & 0-Corante entra $\mathrm{p} / 1 \mathrm{~mm}$ \\
\hline
\end{tabular}


CORPO 5

\begin{tabular}{|c|c|c|}
\hline & MARGEM GENGIVAL & MARGEM OCLUSAL \\
\hline Duze 5.1a & 1 & 0 \\
\hline Duze 5.1b & 2 & 0 \\
\hline Duze 5.2a & 1 & 0 \\
\hline Duze 5.2b & 1 & 0 \\
\hline Duze 5.3a & 4 & 0 \\
\hline Duze 5.3b & 2 & - \\
\hline Duze 5.4a & - & - \\
\hline Duze 5.4b & - & 0 \\
\hline
\end{tabular}

\section{CORPO 6}

\begin{tabular}{|c|c|c|}
\hline & MARGEM GENGIVAL & MARGEM OCLUSAL \\
\hline Duze 6.1a & 0 & 0 \\
\hline Duze 6.1b & 0 & 0 \\
\hline Duze 6.2a & 0 & 0 \\
\hline Duze 6.2b & 0 & 0 \\
\hline Duze 6.3a & 0 & 0 \\
\hline Duze 6.3b & 0 & 0 \\
\hline Duze 6.4a & 0 & 0 \\
\hline Duze 6.4b & 0 & 0 \\
\hline
\end{tabular}

\section{CORPO 7}

\begin{tabular}{|c|c|c|}
\hline & MARGEM GENGIVAL & MARGEM OCLUSAL \\
\hline Duze 7.1a & 0 & 0 \\
\hline Duze 7.1b & 0 & 0 \\
\hline Duze 7.2a & 0 & 0 \\
\hline Duze 7.2b & 0 & 0 \\
\hline Duze 7.3a & 0 & 0 \\
\hline Duze 7.3b & 0 & 0 \\
\hline Duze 7.4a & 0 & 0 \\
\hline Duze 7.4b & 0 & 0 \\
\hline
\end{tabular}

\section{CORPO 8}

\begin{tabular}{|c|c|c|}
\hline & MARGEM GENGIVAL & MARGEM OCLUSAL \\
\hline Duze 8.1a & 0 & 0 \\
\hline Duze 8.1b & 0 & 0 \\
\hline Duze 8.2a & 0 & 0 \\
\hline Duze $8.2 \mathrm{~b}$ & 0 & 0 \\
\hline Duze $8.3 \mathrm{a}$ & 0 & 0 \\
\hline Duze $8.3 \mathrm{~b}$ & 0 & 0 \\
\hline Duze $8.4 \mathrm{a}$ & 0 & 0 \\
\hline Duze $8.4 \mathrm{~b}$ & 0 & 0 \\
\hline
\end{tabular}




\section{CORPO 9}

\begin{tabular}{|c|c|c|}
\hline & MARGEM GENGIVAL & MARGEM OCLUSAL \\
\hline Duze 9.1a & 0 & 0 \\
\hline Duze 9.1b & 0 & 0 \\
\hline Duze 9.2a & 2 & 0 \\
\hline Duze 9.2b & 0 & 0 \\
\hline Duze 9.3a & 1 & 0 \\
\hline Duze 9.3b & 2 & - \\
\hline Duze 9.4a & - & - \\
\hline Duze 9.4b & - & 0 \\
\hline
\end{tabular}

\section{CORPO 10}

\begin{tabular}{|c|c|c|}
\hline & MARGEM GENGIVAL & MARGEM OCLUSAL \\
\hline Duze 10.1a & 0 & 0 \\
\hline Duze 10.1b & 0 & 0 \\
\hline Duze 10.2a & 0 & 0 \\
\hline Duze 10.2b & 0 & 0 \\
\hline Duze 10.3a & 0 & 0 \\
\hline Duze 10.3b & 0 & 0 \\
\hline Duze 10.4a & 0 & 0 \\
\hline Duze 10.4b & 0 & 0 \\
\hline
\end{tabular}

\section{CORPO 11}

\begin{tabular}{|c|c|c|}
\hline & MARGEM GENGIVAL & MARGEM OCLUSAL \\
\hline Duze $11.1 \mathrm{a}$ & 0 & 0 \\
\hline Duze $11.1 \mathrm{~b}$ & 0 & 0 \\
\hline Duze $11.2 \mathrm{a}$ & 0 & 0 \\
\hline Duze $11.2 \mathrm{~b}$ & 0 & 0 \\
\hline Duze $113 \mathrm{a}$ & 0 & 0 \\
\hline Duze $11.3 \mathrm{~b}$ & 0 & 0 \\
\hline Duze $11.4 \mathrm{a}$ & 0 & 0 \\
\hline Duze $11.4 \mathrm{~b}$ & 0 & 0 \\
\hline
\end{tabular}

\section{CORPO 12}

\begin{tabular}{|c|c|c|}
\hline & MARGEM GENGIVAL & MARGEM OCLUSAL \\
\hline Duze 12.1a & 3 & 0 \\
\hline Duze 12.1b & 4 & 0 \\
\hline Duze 12.2a & 4 & 0 \\
\hline Duze 12.2b & 4 & 0 \\
\hline Duze 12.3a & 3 & 0 \\
\hline Duze 12.3b & 3 & 0 \\
\hline Duze 12.4a & 4 & 0 \\
\hline Duze 12.4b & 4 & 0 \\
\hline
\end{tabular}




\section{CORPO 13}

\begin{tabular}{|c|c|c|}
\hline & MARGEM GENGIVAL & MARGEM OCLUSAL \\
\hline Duze 13.1a & 0 & 0 \\
\hline Duze 13.1b & 0 & 0 \\
\hline Duze 13.2a & 0 & 0 \\
\hline Duze 13.2b & 0 & 0 \\
\hline Duze 13.3a & 1 & 0 \\
\hline Duze 13.3b & 1 & - \\
\hline Duze 13.4a & - & - \\
\hline Duze 13.4b & - & 0 \\
\hline
\end{tabular}

\section{CORPO 14}

\begin{tabular}{|c|c|c|}
\hline & MARGEM GENGIVAL & MARGEM OCLUSAL \\
\hline Duze 14.1a & 1 & 1 \\
\hline Duze 14.1b & 0 & 0 \\
\hline Duze 14.2a & 1 & 2 \\
\hline Duze 14.2b & 1 & 2 \\
\hline Duze 14.3a & 1 & 1 \\
\hline Duze 14.3b & 1 & 1 \\
\hline Duze 14.4a & - & - \\
\hline Duze 14.4b & - & - \\
\hline
\end{tabular}

\section{CORPO 15}

\begin{tabular}{|c|c|c|}
\hline & MARGEM GENGIVAL & MARGEM OCLUSAL \\
\hline Duze 15.1a & 1 & 0 \\
\hline Duze 15.1b & 1 & 1 \\
\hline Duze 15.2a & 1 & 1 \\
\hline Duze 15.2b & 0 & 1 \\
\hline Duze 15.3a & 1 & 1 \\
\hline Duze 15.3b & 1 & - \\
\hline Duze 15.4a & - & - \\
\hline Duze 15.4b & - & 1 \\
\hline
\end{tabular}

\section{CORPO 16}

\begin{tabular}{|c|c|c|}
\hline & MARGEM GENGIVAL & MARGEM OCLUSAL \\
\hline Duze 16.1a & 1 & 1 \\
\hline Duze 16.1b & 0 & 0 \\
\hline Duze 16.2a & 1 & 1 \\
\hline Duze 16.2b & 1 & 2 \\
\hline Duze 16.3a & 1 & 2 \\
\hline Duze 16.3b & 1 & - \\
\hline Duze 16.4a & - & - \\
\hline Duze 16.4b & - & \\
\hline
\end{tabular}


CORPO 17

\begin{tabular}{|c|c|c|}
\hline & MARGEM GENGIVAL & MARGEM OCLUSAL \\
\hline Duze 17.1a & 1 & 1 \\
\hline Duze 17.1b & 1 & 1 \\
\hline Duze 17.2a & 1 & 1 \\
\hline Duze 17.2b & 1 & 1 \\
\hline Duze 17.3a & 1 & 0 \\
\hline Duze 17.3b & 1 & - \\
\hline Duze 17.4a & - & - \\
\hline Duze 17.4b & - & 1 \\
\hline
\end{tabular}

\section{CORPO 18}

\begin{tabular}{|c|c|c|}
\hline & MARGEM GENGIVAL & MARGEM OCLUSAL \\
\hline Duze $18.1 \mathrm{a}$ & 3 & 2 \\
\hline Duze $18.1 \mathrm{~b}$ & 4 & 3 \\
\hline Duze $18.2 \mathrm{a}$ & 4 & 2 \\
\hline Duze $18.2 \mathrm{~b}$ & 4 & 1 \\
\hline Duze18.3a & 4 & 1 \\
\hline Duze $18.3 \mathrm{~b}$ & 4 & - \\
\hline Duze $18.4 \mathrm{a}$ & - & - \\
\hline Duze $18.4 \mathrm{~b}$ & - & 2 \\
\hline
\end{tabular}

\section{CORPO 19}

\begin{tabular}{|c|c|c|}
\hline & MARGEM GENGIVAL & MARGEM OCLUSAL \\
\hline Duze 19.1a & 1 & 0 \\
\hline Duze 19.1b & 1 & 0 \\
\hline Duze 19.2a & 1 & 1 \\
\hline Duze 19.2b & 1 & 2 \\
\hline Duze 19.3a & 1 & 2 \\
\hline Duze 19.3b & 1 & - \\
\hline Duze 19.4a & - & - \\
\hline Duze 19.4b & - & 1 \\
\hline
\end{tabular}

GRUPO DE 1000 CICLOS

\section{CORPO 1}

\begin{tabular}{|c|c|c|}
\hline & MARGEM GENGIVAL & MARGEM OCLUSAL \\
\hline Mil 1.1a & 0 & 0 \\
\hline Mil 1.1b & 0 & 0 \\
\hline Mil 1.2a & 0 & 0 \\
\hline Mil 1.2b & 0 & 0 \\
\hline Mil 1.3a & 0 & 0 \\
\hline Mil 1.3b & 0 & 0 \\
\hline Mil 1.4a & 0 & 0 \\
\hline Mil 1.4b & 0 & 0 \\
\hline
\end{tabular}


CORPO 2

\begin{tabular}{|c|c|c|}
\hline & MARGEM GENGIVAL & MARGEM OCLUSAL \\
\hline Mil 2.1a & 0 & 0 \\
\hline Mil 2.1b & 0 & 0 \\
\hline Mil 2.2a & 0 & 0 \\
\hline Mil 2.2b & 0 & 0 \\
\hline Mil 2.3a & 0 & 0 \\
\hline Mil 2.3b & 0 & 0 \\
\hline Mil 2.4a & 0 & 0 \\
\hline Mil 2.4b & 0 & 0 \\
\hline
\end{tabular}

CORPO 3

\begin{tabular}{|c|c|c|}
\hline & MARGEM GENGIVAL & MARGEM OCLUSAL \\
\hline Mil 3.1a & 1 & 0 \\
\hline Mil 3.1b & 0- sem restauração & 0-sem restauração \\
\hline Mil 3.2a & 2 & 0 \\
\hline Mil 3.2b & 2 & 0 \\
\hline Mil 3.3a & 1 & 0 \\
\hline Mil 3.3b & 1 & 0 \\
\hline Mil 3.4a & 3 & 0 \\
\hline Mil 3.4b & 3 & 0 \\
\hline
\end{tabular}

\section{CORPO 4}

\begin{tabular}{|c|c|c|}
\hline & MARGEM GENGIVAL & MARGEM OCLUSAL \\
\hline Mil 4.1a & 0 & 0 \\
\hline Mil 4.1b & 0 & 0 \\
\hline Mil 4.2a & 0 & 0 \\
\hline Mil 4.2b & 0 & 0 \\
\hline Mil 4.3a & 0 & 0 \\
\hline Mil 4.3b & 0 & 0 \\
\hline Mil 4.4a & 0 & 0 \\
\hline Mil 4.4b & 0 & 0 \\
\hline
\end{tabular}

CORPO 5

\begin{tabular}{|c|c|c|}
\hline & MARGEM GENGIVAL & MARGEM OCLUSAL \\
\hline Mil 5.1a & 0 & 0 \\
\hline Mil 5.1b & 0 & 0 \\
\hline Mil 5.2a & 0 & 0 \\
\hline Mil 5.2b & 0 & 0 \\
\hline Mil 5.3a & 0 & 0 \\
\hline Mil 5.3b & 0 & 0 \\
\hline Mil 5.4a & 0 & 0 \\
\hline Mil 5.4b & 0 & 0 \\
\hline
\end{tabular}


CORPO 6

\begin{tabular}{|c|c|c|}
\hline & MARGEM GENGIVAL & MARGEM OCLUSAL \\
\hline Mil 6.1a & 0 & 0 \\
\hline Mil 6.1b & 0 & 0 \\
\hline Mil 6.2a & 0 & 0 \\
\hline Mil 6.2b & 0 & 0 \\
\hline Mil 6.3a & 0 & 0 \\
\hline Mil 6.3b & 0 & 0 \\
\hline Mil 6.4a & 0 & 0 \\
\hline Mil 6.4b & 0 & 0 \\
\hline
\end{tabular}

CORPO 7

\begin{tabular}{|c|c|c|}
\hline & MARGEM GENGIVAL & MARGEM OCLUSAL \\
\hline Mil 7.1a & 4 & 0 \\
\hline Mil 7.1b & 3 & 0 \\
\hline Mil 7.2a & 4 & 0 \\
\hline Mil 7.2b & 4 & 0 \\
\hline Mil 7.3a & 3 & 0 \\
\hline Mil 7.3b & 3 & - \\
\hline Mil 7.4a & - & - \\
\hline Mil 7.4b & - & \\
\hline
\end{tabular}

\section{CORPO 8}

\begin{tabular}{|c|c|c|}
\hline & MARGEM GENGIVAL & MARGEM OCLUSAL \\
\hline Mil 8.1a & 0 & 0 \\
\hline Mil 8.1b & 0 & 0 \\
\hline Mil 8.2a & 0 & 0 \\
\hline Mil 8.2b & 0 & 0 \\
\hline Mil 8.3a & 0 & 0 \\
\hline Mil 8.3b & 0 & 0 \\
\hline Mil 8.4a & 0 & 0 \\
\hline Mil 8.4b & 0 & 0 \\
\hline
\end{tabular}

\section{CORPO 9}

\begin{tabular}{|c|c|c|}
\hline & MARGEM GENGIVAL & MARGEM OCLUSAL \\
\hline Mil 9.1a & 2 & 0 \\
\hline Mil 9.1b & 2 & 0 \\
\hline Mil 9.2a & 2 & 0 \\
\hline Mil 9.2b & 2 & 0 \\
\hline Mil 9.3a & 1 & 0 \\
\hline Mil 9.3b & 1 & - \\
\hline Mil 9.4a & - & - \\
\hline Mil 9.4b & - & 2 \\
\hline
\end{tabular}




\section{CORPO 10}

\begin{tabular}{|c|c|c|}
\hline & MARGEM GENGIVAL & MARGEM OCLUSAL \\
\hline Mil 10.1a & 0 & 0 \\
\hline Mil 10.1b & 0 & 0 \\
\hline Mil 10.2a & 0 & 0 \\
\hline Mil 10.2b & 0 & 1 \\
\hline Mil 10.3a & 0 & 1 \\
\hline Mil 10.3b & 0 & - \\
\hline Mil 10.4a & - & - \\
\hline Mil 10.4b & - & 0 \\
\hline
\end{tabular}

\section{CORPO 11}

\begin{tabular}{|c|c|c|}
\hline & MARGEM GENGIVAL & MARGEM OCLUSAL \\
\hline Mil 11.1a & 1 & 0 \\
\hline Mil 11.1b & 1 & 0 \\
\hline Mil 11.2a & 0 & 0 \\
\hline Mil 11.2b & 0 & 0 \\
\hline Mil 11.3a & 1 & 0 \\
\hline Mil 11.3b & 1 & 0 \\
\hline Mil 11.4a & 1 & 0 \\
\hline Mil 11.4b & 1 & 0 \\
\hline
\end{tabular}

\section{CORPO 12}

\begin{tabular}{|c|c|c|}
\hline & MARGEM GENGIVAL & MARGEM OCLUSAL \\
\hline Mil 12.1a & 0 & 0 \\
\hline Mil 12.1b & 0 & 0 \\
\hline Mil 12.2a & 1 & 0 \\
\hline Mil 12.2b & 1 & - \\
\hline Mil 12.3a & - & - \\
\hline Mil 12.3b & - & - \\
\hline Mil 12.4a & - & - \\
\hline Mil 12.4b & - & 0 \\
\hline
\end{tabular}

\section{CORPO 13}

\begin{tabular}{|c|c|c|}
\hline & MARGEM GENGIVAL & MARGEM OCLUSAL \\
\hline Mil 13.1a & 0 & 2 \\
\hline Mil 13.1b & 0 & 2 \\
\hline Mil 13.2a & 0 & 1 \\
\hline Mil 13.2b & 0 & 3 \\
\hline Mil 13.3a & 0 & 4 \\
\hline Mil 13.3b & 0 & - \\
\hline Mil 13.4a & - & - \\
\hline Mil 13.4b & - & \\
\hline
\end{tabular}




\section{CORPO 14}

\begin{tabular}{|c|c|c|}
\hline & MARGEM GENGIVAL & MARGEM OCLUSAL \\
\hline Mil 14.1a & 3 & 2 \\
\hline Mil 14.1b & 3 & 2 \\
\hline Mil 14.2a & 4 & 1 \\
\hline Mil 14.2b & 3 & 2 \\
\hline Mil 14.3a & 3 & 2 \\
\hline Mil 14.3b & 3 & - \\
\hline Mil 14.4a & - & - \\
\hline Mil 14.4b & - & 1 \\
\hline
\end{tabular}

\section{CORPO 15}

\begin{tabular}{|c|c|c|}
\hline & MARGEM GENGIVAL & MARGEM OCLUSAL \\
\hline Mil 15.1a & 2 & 0 \\
\hline Mil 15.1b & 2 & 0 \\
\hline Mil 15.2a & 1 & 0 \\
\hline Mil 15.2b & 1 & 0 \\
\hline Mil 15.3a & 2 & 0 \\
\hline Mil 15.3b & 1 & - \\
\hline Mil 15.4a & - & - \\
\hline Mil 15.4b & - & 2 \\
\hline
\end{tabular}

\section{CORPO 16}

\begin{tabular}{|c|c|c|}
\hline & MARGEM GENGIVAL & MARGEM OCLUSAL \\
\hline Mil 16.1a & 2 & 0-entrou pelo $1 \mathrm{~mm}$ \\
\hline Mil 16.1b & 2 & 0-entrou pelo $1 \mathrm{~mm}$ \\
\hline Mil 16.2a & 1 & 0-entrou pelo $1 \mathrm{~mm}$ \\
\hline Mil 16.2b & 1 & 0-entrou pelo $1 \mathrm{~mm}$ \\
\hline Mil 16.3a & 1 & 0-entrou pelo $1 \mathrm{~mm}$ \\
\hline Mil 16.3b & 1 & 0-entrou pelo $1 \mathrm{~mm}$ \\
\hline Mil 16.4a & - & - \\
\hline Mil 16.4b & - & - \\
\hline
\end{tabular}

\section{CORPO 17}

\begin{tabular}{|c|c|c|}
\hline & MARGEM GENGIVAL & MARGEM OCLUSAL \\
\hline Mil 17.1a & 0 & 0 \\
\hline Mil 17.1b & 0 & 0 \\
\hline Mil 17.2a & 0 & 0 \\
\hline Mil 17.2b & 0 & 0 \\
\hline Mil 17.3a & 0 & 0 \\
\hline Mil 17.3b & 0 & 0 \\
\hline Mil 17.4a & 0 & 0 \\
\hline Mil 17.4b & 0 & 0 \\
\hline
\end{tabular}


CORPO 18

\begin{tabular}{|c|c|c|}
\hline & MARGEM GENGIVAL & MARGEM OCLUSAL \\
\hline Mil 18.1a & 0-entrou pelo $1 \mathrm{~mm}$ & 2 \\
\hline Mil 18.1b & 0-entrou pelo 1mm & 2 \\
\hline Mil 18.2a & 0-entrou pelo 1mm & 2 \\
\hline Mil 18.2b & 0-entrou pelo 1mm & 2 \\
\hline Mil 18.3a & 0-entrou pelo 1mm & 2 \\
\hline Mil 18.3b & 0-entrou pelo 1mm & - \\
\hline Mil 18.4a & - & - \\
\hline Mil 18.4b & - & 2 \\
\hline
\end{tabular}

\section{CORPO 19}

\begin{tabular}{|c|c|c|}
\hline & MARGEM GENGIVAL & MARGEM OCLUSAL \\
\hline Mil 19.1a & 0 & 0-entrou pelo 1mm \\
\hline Mil 19.1b & 1 & 0-entrou pelo 1mm \\
\hline Mil 19.2a & 1 & 0-entrou pelo 1 $1 \mathrm{~mm}$ \\
\hline Mil 19.2b & 1 & 0 -entrou pelo $1 \mathrm{~mm}$ \\
\hline Mil 19.3a & 0 & 0-entrou pelo $1 \mathrm{~mm}$ \\
\hline Mil 19.3b & 0 & 0-entrou pelo $1 \mathrm{~mm}$ \\
\hline Mil 19.4a & - & - \\
\hline Mil 19.4b & - & - \\
\hline
\end{tabular}

